\title{
ESTUDO EVOLUTIVO DE ESPÉCIES E HÍBRIDOS DE CANA-DE-AÇÚCAR POR ANÁLISE COMPARATIVA COM OUTRAS ESPÉCIES DA FAMÍLIA POACEAE (ARROZ, MILHO, SORGO E TRIGO) UTILIZANDO REGIÕES DO GENOMA CLOROPLASTIDIAL
}

\section{DANILA MONTEWKA MELOTTO-PASSARIN \\ Engenheira Agrônoma}

Orientadora: Profa. Dra. HeLAINE CARRER

Dissertação apresentada à Escola Superior de Agricultura "Luiz de Queiroz", Universidade de São Paulo, para obtenção do título de Mestre em Ciências, Área de Concentração: Fisiologia e Bioquímica de Plantas.

P I R A C I C A BA

Estado de São Paulo - Brasil

Junho -2004 
Dados Internacionais de Catalogação na Publicação (CIP) DIVISÃO DE BIBLIOTECA E DOCUMENTAÇÃO - ESALQIUSP

\author{
Melotto-Passarin, Danila Montewka \\ Estudo evolutivo de espécies e hibridos de cana-de-açúcar por análise \\ comparativa com outras espécies da familia Poaceae (arroz, milho, sorgo e trigo) \\ utilizando regiōes do genoma cloroplastidial / Danila Montewka Melotto-Passarin. - \\ Piracicaba, 2004. \\ 134 p. : il. \\ Dissertação (mestrado) - - Escola Superior de Agricultura Luiz de Queiroz, 2004. \\ Bibliografia. \\ 1. Cana-de-açúcar 2. Cloroplasto vegetal 3. Evolução vegetal 4. Filogenia 5. Melho- \\ ramento genético vegetal 6 . Polimorfismo 7 . Seqüência de nucleotideo 1 . Titulo
}

CDD 633.61

Permitida a copla total ou parcial deste documento, desde que citada a fonte $=0$ autor" 
Nossas vidas tocam algumas vidas uma vez nesta caminhada; e depois os caminhos se separam para nunca mais se encontrarem. Portanto não chore porque terminou, mas sorria porque aconteceu. Siga tranqüilamente, entre a inquietude e a pressa, lembrando-se que sempre há paz no silêncio. Quando virmos em Jesus nossos caminho e paz, Deus colocará beleza e cor nas pequenas coisas que nos acontecem, pois tudo sucede por alguma coisa. Então mantenha boas relações com outras pessoas, amando ao seu próximo como a si mesmo, falando a sua verdade, mansa e claramente, $e$ ouça a dos outros, mesmo a dos insensatos e ignorantes, pois também eles têm sua própria história. Portanto, somos agora mais fortes e prontos para continuar em nossa caminhada. 
Em memória a Elias Melotto,

Meu querido pai,

Pelo amor, compreensão e carinho

DEDICO

À minha mãe Helena Montewka Melotto,

Às minhas irmãs Carolina e Ludimila,

Ao meu marido Rogério e ao meu filho Matheus

OFEREÇO 


\section{AGRADECIMENTOS}

Agradeço a Deus por estar presente em toda caminhada de minha vida, me dando força, saúde e paz.

Agradeço ao meu marido Rogério, pelo incentivo e apoio incondicional em todos os momentos.

Ao meu filho Matheus, por sua existência e alegria, renovando e multiplicando a plenitude da família.

Agradeço aos meus pais, Elias e Helena, pela vida, educação e companheirismo. A eles minha total gratidão, e a esperança de seguir este exemplo para com meu filho. Aos meus avós, Stanislaw, Catarina e Atanásia por me ensinarem os valores da terra e da vida. Às minhas queridas irmãs, Carolina e Ludimila, pela amizade, incentivo, apoio e afeto.

A toda a minha família pelo incentivo e participação em todas as etapas da minha vida.

À Profa. Helaine Carrer, agradeço pela oportunidade e contínua orientação, exemplo, apoio e condições para meu desenvolvimento pessoal e profissional na Pesquisa Científica.

Agradeço a todos os integrantes do Centro de Biotecnologia Agrícola, do Departamento de Ciências Biológicas da ESALQ-USP. Aos professores Otto Jesu Crocomo, Murilo de Melo e Luiz Antonio Gallo, pela amizade e orientação em inúmeros momentos. Aos funcionários Maria Solizete G. Silva, Antonio F. C. do Amaral, Enio Tiago de Oliveira, agradeço pela amizade e pelo auxílio nas etapas deste trabalho.

Agradeço ao Tercilio Calsa Junior, pela experiência partilhada na pesquisa com sugestões importantes, pela amizade e exemplo. 
À Valentina de Fátima de Martin, agradeço pela participação no desenvolvimento da pesquisa, sugestões, críticas e pela amizade.

Agradeço a todos os integrantes do Laboratório de Biologia Molecular do Centro de Biotecnologia Agrícola, Depto. de Ciências Biológicas - ESALQ-USP, pelo convívio em equipe, pela amizade e companheirismos, pelas sugestões, críticas e opiniões, favorecendo o desenvolvimento deste trabalho. Aos amigos Simone, Valesca, Maria Clara, Rosana, Keini, Vivian, Raquel, Letícia, Flávia, Adriano, Henrique, Irving, Reimar, Danilo, Antonio Mathias, Carlos e Eduardo pelo convívio alegre.

Agradeço à FAPESP pelo incentivo e apoio financeiro disponibilizado para o desenvolvimento deste trabalho.

Agradeço, enfim, a todos que, direta ou indiretamente, colaboraram para a realização deste trabalho. 


\section{SUMÁRIO}

Página

LISTA DE FIGURAS................................................................................. ix

LISTA DE TABELAS.............................................................................

LISTA DE ABREVIATURAS, SÍMBOLOS E EXPRESSÕES.............................. xii

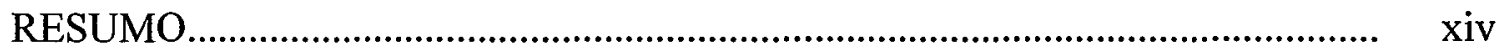

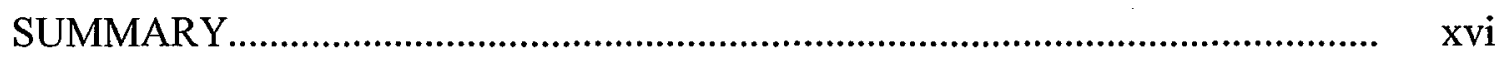

1 INTRODUÇÃO ................................................................ 1

2 REVISÃO DE LITERATURA................................................ 3

2.1 Importância e Classificação Botânica da Cana-de-Açúcar................................... 3

2.2 Centros de Origem de Espécies da Família Poaceae ........................................... 4

2.3 Melhoramento Genético e Evolução..................................................................... 5

2.4 Características e Origem dos Plastídios............................................................... 7

2.5 Regulação Gênica nos Cloroplastos.................................................................... 10

2.6 Análise Filogenética e Evolução dos Cloroplastos............................................. 12

2.7 Análise Comparativa de Plastomas da Família Poaceae..................................... 17

3 MATERIAL E MÉTODOS..................................................................... 21

3.1 Material Vegetal.......................................................................................... 21

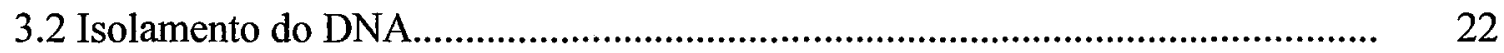

3.2.1 DNA cloroplastidial............................................................................ 22

3.2.2 Extração de DNA total.......................................................................................

3.3 Identificação das Regiões dos Plastomas........................................................... 23

3.4 Reação em Cadeia da Polimerase (PCR) das Sequiências Alvo.......................... 24

3.5 Clonagem de Seqüências Alvo............................................................................. 27 


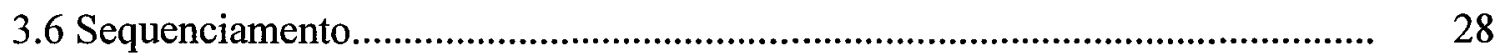

3.7 Análise das Seqüências...................................................................................... 29

3.8 Análise Comparativa de Edição de mRNA por RT-PCR...................................... 32

3.8.1 Extração de RNA total.................................................................................... 34

3.8.2 Síntese de cDNA.....................................................................................

4 RESULTADOS E DISCUSSÃO.................................................................. 36

4.1 Material Vegetal....................................................................................... 36

4.2 Isolamento do DNA dos Cloroplastos............................................................. 36

4.3 Extração de DNA Total................................................................................

4.4 Clonagem de Seqüências Alvo........................................................................... 37

4.5 Sequenciamento dos Clones e Produtos de PCR.............................................. 38

4.6 Análise Comparativa das Seqüências de Nucleotídeos......................................... 45

4.6.1 Comparação das posições das intersecções dos plastomas de espécies

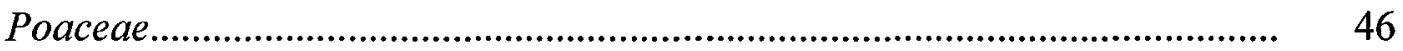

4.6.2 Análise das regiões divergentes dos plastomas de espécies e híbridos de cana-de-açúcar comparados com outras espécies da família Poaceae............ $\quad 49$

4.6.3 Análise filogenética das espécies Poaceae estudadas...................................... 59

4.7 Análise Comparativa de Edição do mRNA de Sorgo.......................................... 66

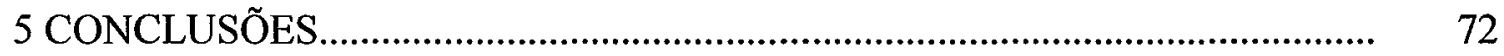

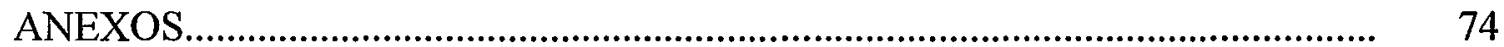

REFERÊNCIAS BIBLIOGRÁFICAS............................................................ 119 


\section{LISTA DE FIGURAS}

Página

1 Variação entre os plastomas de plantas terrestres na região intergênica trnItrnL. Linhas tracejadas representam deleções no grupo Poaceae.

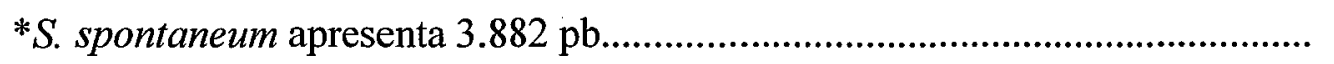

2 Variação entre os plastomas de plantas terrestres na região intergênica $r b c L$ petA. Comparando tabaco, arroz, trigo, sorgo, milho e cana-de-açúcar, é observada uma tendência para perda do gene $a c c D$, onde o arroz ocupa um lugar intermediário. * $S$. robustum e $S$. spontaneum apresentam,

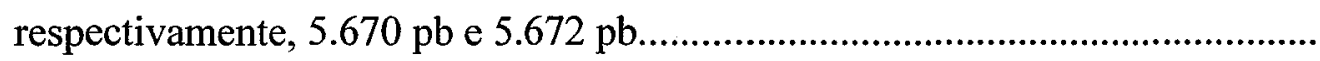

3 Comparação das relativas posições das intersecções $\mathrm{LSC}_{\mathrm{IR}}, \mathrm{IR}_{\mathrm{A}} / \mathrm{SSC}$, $\mathrm{SSC} / \mathrm{IR}_{\mathrm{B}}, \mathrm{IR}_{\mathrm{B}} / \mathrm{LSC}$ e os genes $p s b A, n d h H, n d h F$ e $r p l 22$, respectivamente, entre os plastomas da cana-de-açúcar, sorgo, milho, arroz e trigo.....................

4 Destaque de parte do alinhamento da região que inclui o gene $n d h F$ representados por A e B. Os pontos alinhados representam as mesmas bases nitrogenadas do híbrido SP80-3280. Os traços representam os gaps (deleções de bases nitrogenadas). As mutações são apresentadas pelas bases nitrogenadas em negrito que diferem do híbrido SP80-3280 ...........................

5 Destaque de parte do alinhamento da região intergênica $\operatorname{trn} I$-trnL representados por A e B. Os pontos alinhados representam as mesmas bases nitrogenadas do híbrido SP80-3280. Os traços representam os gaps (deleções de bases nitrogenadas). As mutações são apresentadas pelas bases nitrogenadas em negrito que diferem do híbrido SP80-3280 
6 Destaque de parte do alinhamento da região intergênica $r b c L$-petA representados por A e B. Os pontos alinhados representam as mesmas bases nitrogenadas do híbrido SP80-3280. Os traços representam os gaps (deleções de bases nitrogenadas). As mutações são apresentadas pelas bases nitrogenadas em negrito que diferem do híbrido SP80-3280............................

7 Relação filogenética entre espécies e híbridos de cana-de-açúcar e outras espécies gramíneas como trigo, arroz, milho e sorgo. Esta é uma árvore de parcimônia considerando todas as regiões do ptDNA selecionadas. Os números são valores de Bootstrap com porcentagens acima de $50 \%$.................

8 Relação filogenética entre espécies e híbridos de cana-de-açúcar e outras espécies gramíneas como trigo, arroz, milho e sorgo. Esta é uma árvore de parcimônia considerando a região do ptDNA que inclui somente o gene $n d h F$. Os números são valores de Bootstrap com porcentagens acima de $50 \%$

9 Relação filogenética entre espécies e híbridos de cana-de-açúcar e outras espécies gramíneas como trigo, arroz, milho e sorgo. Esta é uma árvore de

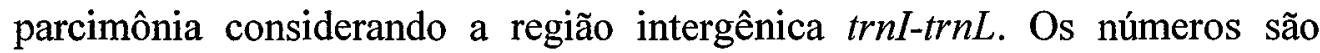

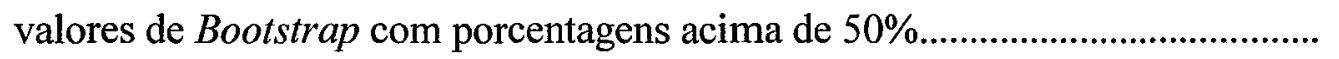

10 Relação filogenética entre espécies e híbridos de cana-de-açúcar e outras espécies gramíneas como trigo, arroz, milho e sorgo. Esta é uma árvore de parcimônia considerando a região intergênica $r b c L$-petA. Os números são valores de Bootstrap com porcentagens acima de 50\%

11 RT-PCR para análise de edição de transcritos de sorgo. (A) Bandas correspondentes às regiões editadas dos genes $y c f 3(1), n d h B(2), r p o C 2$ (3), $n d h D(4), r p l 2$ (5), rpoB (6), rps14 (7), ndhF (8), rpl20 (9) amplificadas a partir do cDNA obtido de RNA não tratado com DNAse I. (B) Bandas correspondentes às regiões amplificadas do DNA total das regiões dos genes $y c f 3(1), n d h B(2), n d h A$ (3) e a partir do cDNA obtido de RNA tratado com DNAse I das regiões editadas dos genes $n d h B(4), n d h A(5), \operatorname{pet} B(6), n d h D$ (7), rpl2 (8), atpA (9), rps8 (10). L = 1 kb DNA ladder plus. 


\section{LISTA DE TABELAS}

Página

1 Espécies e híbridos de cana-de-açúcar estudadas.................................................. 21

2 Plastomas de gramíneas estudadas..................................................................... 24

3 Primers utilizados para amplificação de regiões de interesse do ptDNA........... 25

4 Quantificação de amostras de DNA para reação de sequenciamento................. 29

5 Primers para análise de edição de mRNA no plastoma de sorgo........................ 33

6 Comprimento das sequiências alvo analisadas em pares de base......................... 38

7 Tamanho dos fragmentos amplificados a partir do DNA e cDNA total de

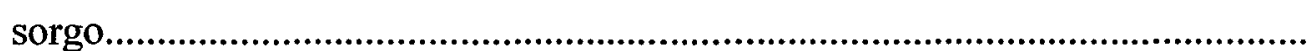

8 Sítios de edição do mRNA detectados no plastoma de sorgo (Sorghum bicolor) e comparados aos sítios presentes em cana-de-açúcar (Calsa Junior, 2001) e milho (Maier et al., 1995)..................................................................... 


\section{LISTA DE ABREVIATURAS, SÍMBOLOS E EXPRESSÕES}

A Adenina

A. C. Antes de Cristo

$\mathrm{C}$

Citosina

$\mathrm{C}_{3} \quad$ Fotossintese com fixação inicial de $\mathrm{CO}_{2}$ em composto de 3 carbonos

$\mathrm{C}_{4} \quad$ Fotossintese com fixação inicial de $\mathrm{CO}_{2}$ em composto de 4 carbonos

cDNA DNA complementar ao mRNA

cpDNA Abreviatura de DNA cloroplastidial em inglês

CTAB Brometo de hexadeciltrimetilamônio

$\mathrm{ddH}_{2} \mathrm{O} \quad$ Água destilada, deionizada (Milli-Q) e esterilizada

DEPC Dietilpirocarbonato

DH5- $\alpha \quad$ Cepa de células competentes de Escherichia coli

DNA Ácido desoxirribonucléico

DNAse I Desoxirribonuclease I

EDTA Ácido etilenodiaminotetracético

Forward Primer Direto

G Guanina

Gap Deleção de base nitrogenada

Hotspot Ponto de divergência

Indel Inserção e deleção de base nitrogenada

IPTG $\quad \beta$-D-isopropil-tiogalactopiranosídeo

IR Repetição invertida

$\mathrm{Kb} \quad$ Kilobases 
LSC Região grande de cópia única

mRNA RNA mensageiro

NADH Nicotinamida-adenosina-di-fosfato

ORF Seqüência de leitura aberta (open reading frame)

$\mathrm{pb} \quad$ Pares de bases

PEPC Fosfoenolpiruvato carboxilase

PCR Reação em cadeia da polimerase

PS I Fotossistema I

PS II Fotossistema II

ptDNA DNA cloroplastidial

rDNA Seqüência de DNA codificador de RNA ribossômico

Reverse Primer reverso

RNAse Ribonuclease

rRNA RNA ribossômico

Rubisco Ribulose-1,5-bisfosfato carboxilase/oxigenase

SSC Região pequena de cópia única

T Timina

TAE Tampão de eletroforese Tris - Acetato - EDTA

TBE Tampão de eletroforese Tris - Ácido Bórico - EDTA

tRNA RNA transportador

U Uracila

V.cm ${ }^{-1} \quad$ Volts. $\mathrm{cm}^{-1}$

$\mathrm{xg} \quad$ Múltiplos de força gravitacional terrestre (rcf)

$\mathrm{X}$-Gal 5-bromo-4-cloro-3-indolil- $\beta$-galactopiranosídeo

ycf Genes putativos cloroplastidiais conservados (hypothetical chloroplast frames) 


\title{
ESTUDO EVOLUTIVO DE ESPÉCIES E HÍBRIDOS DE CANA-DE-AÇÚCAR POR ANÁLISE COMPARATIVA COM OUTRAS ESPÉCIES DA FAMÍLIA POACEAE (ARROZ, MILHO, SORGO E TRIGO) UTILIZANDO REGIÕES DO GENOMA CLOROPLASTIDIAL
}

\author{
Autora: DANILA MONTEWKA MELOTTO-PASSARIN \\ Orientadora: Profa. Dra. HELAINE CARRER
}

\section{RESUMO}

Nos últimos anos, o sequenciamento de nucleotídeos do genoma cloroplastidial está sendo utilizado como uma eficiente ferramenta para estudar a evolução em plantas superiores. O completo sequenciamento do genoma cloroplastidial (plastoma) de canade-açúcar (Saccharum officinarum) revelou uma molécula circular fechada de 141.182 $\mathrm{pb}$. Este plastoma contém um par de regiões invertidas repetidas $\left(\mathrm{IR}_{\mathrm{A}} \mathrm{e} \mathrm{IR}_{\mathrm{B}}\right)$, separadas por uma região de cópia única pequena (SSC) e uma região de cópia única grande (LSC). Os genes do cloroplasto têm sido muito utilizados para reconstruir a filogenia em espécies relacionadas. Para contribuir com a quantidade de informação disponível para a reconstrução filogenética, múltiplas regiões do cloroplasto têm sido analisadas, incluindo genes e espaçadores intergênicos. O DNA cloroplastidial (ptDNA) tem a característica de ser muito conservado entre as espécies de plantas, o que o torna apropriado para os estudos filogenéticos em vários níveis taxonômicos. Além disso, a herança uniparental apresenta reduzido impacto da recombinação intermolecular e auxilia na simplificação das teorias de evolução do ptDNA em muitos táxons vegetais. 
O objetivo deste trabalho foi contribuir com os estudos de evolução do cloroplasto em várias espécies e híbridos de cana-de-açúcar pela identificação de regiões polimórficas e sinais filogenéticos ou "hotspots" que possam ser utilizados como marcadores filogenéticos. Para isso, outras espécies pertencentes à família Poaceae, principalmente sorgo, milho, arroz e trigo também foram utilizadas nas análises. As regiões selecionadas para este estudo foram: região intergênica entre $r b c L$ e petA; região intergênica entre trnI e trnL; região $16 S$ rDNA e um segmento das quatro intersecções do ptDNA que unem as duas regiões invertidas repetidas com a LSC e SSC. Estas seqüências foram amplificadas por PCR, seqüenciadas e alinhadas utilizando os programas computacionais ClustalW e Phred-Phrap-Consed. As análises de parcimônia foram realizadas pelo programa $P A U P^{*}$ versão $4.0 \mathrm{e}$ as árvores filogenéticas foram desenhadas pelo programa TreeView. As comparações dos "hotspots" do ptDNA forneceram informações quanto a evolução do cloroplasto e sobre os mecanismos responsáveis pela divergência entre os plastomas destas espécies estudadas. Também foi observada maior identidade entre os plastomas de cana-de-açúcar, sorgo e milho, que são plantas $\mathrm{C}_{4}$, do que entre os plastomas de cana-de-açúcar e de gramíneas $\mathrm{C}_{3}$ como arroz e trigo, incluindo a organização estrutural dos genes. 


\title{
EVOLUTIVE STUDY OF SUGARCANE SPECIES AND HYBRIDS BY COMPARATIVE ANALYSIS WITH OTHERS SPECIES OF POACEAE FAMILY (RICE, MAIZE, SORGHUM AND WHEAT) USING REGIONS OF CLOROPLASTIDIAL GENOME
}

\author{
Author: DANILA MONTEWKA MELOTTO-PASSARIN \\ Adviser: Profa. Dra. HELAINE CARRER
}

\section{SUMMARY}

In the past few years, nucleotide sequencing of chloroplast genome is being used as an efficient tool to study evolution in higher plants. Sequencing of the total chloroplast genome (plastome) from sugarcane (Saccharum officinarum) revealed a $141,182 \mathrm{bp}$ circular double-stranded molecule. This plastome contains a pair of inverted repeat regions ( $\left(\mathrm{R}_{\mathrm{A}}\right.$ and $\mathrm{IR}_{\mathrm{B}}$ ), separating a small single copy region (SSC) and a large single copy region (LSC). Chloroplast genes have been extensively used to reconstruct the phylogeny in related species. In order to contribute to the amount of information available for phylogenetic reconstruction, it has been analyzed multiple chloroplast regions, including genes and intergenic spacers. The chloroplast DNA (cpDNA) has the feature of being well conserved among the plant species, which makes it appropriate for phylogenetic studies at high taxonomic levels. Furthermore, uniparental inheritance presents low impact of intermolecular recombination and helps to simplify theories of ptDNA evolution in most plant taxa. The objective of this work was to contribute to chloroplast evolution studies in several sugarcane species and hybrids by identifying 
polymorphic regions and phylogenetic signals or hotspots signals that can be useful as phylogenetic markers. For that, other species belonging to Poaceae family, mainly sorghum, maize, rice and wheat have also been comprised in the analyses. The regions selected to this study were: intergenic region between $r b c L$ and $p e t A$; intergenic region between $\operatorname{trnI}$ and $\operatorname{trnL} ; 16 \mathrm{~S}$ rDNA region and a segment of the four cpDNA intersections that link the two inverted repeat regions with the LSC and SSC. These sequences have been amplified by PCR, sequenced and aligned by using the computer programs ClustalW and Phred-Phrap-Consed. The parsimony analyses were performed by PAUP* version 4.0 program and the phylogenetic trees were designed by TreeView program. The comparisons of cpDNA hotspots have provided useful information on chloroplast evolution and about the mechanisms responsible for divergence among plastomes of these studied species. Also, it was observed larger identity among sugarcane, sorghum and maize plastomes, which are $\mathrm{C}_{4}$ plants, than between sugarcane and $\mathrm{C}_{3}$ grasses plastomes like rice and wheat, including structural gene organization. 


\section{INTRODUÇÃO}

A cana-de-açúcar (Saccharum spp.) pertence à família Poaceae, sendo considerada uma das culturas agrícolas mais importantes do mundo, principalmente pelo complexo industrial que gira em torno do seu cultivo, gerando empregos e contribuindo para a alimentação humana e animal. Neste sentido, o melhoramento genético da canade-açúcar aparece como base fundamental para se obter novas variedades para a manutenção e incremento no agronegócio brasileiro.

As espécies de cana-de-açúcar são originárias do continente asiático, mais especificamente da Índia. No gênero Saccharum ocorrem seis espécies: Saccharum officinarum L. $(2 n=80)$, S. robustum Brandes e Jeswit $(2 n=60-205)$, S. barberi Jeswit $(2 \mathrm{n}=81-124), S$. sinense Roxb ( $\mathrm{n}=111-120)$, S. spontaneum L. $(2 \mathrm{n}=40-128)$ e $S$. edule Hassk $(2 \mathrm{n}=60-80)$ (Daniels \& Roach, 1987). Muito pouco é conhecido sobre o nível de similaridade entre estas espécies e sobre a herança genética citoplasmática dos híbridos utilizados em plantios comerciais. As variedades comerciais de cana-de-açúcar são oriundas principalmente de cruzamentos interespecíficos de Saccharum officinarum e Saccharum spontaneum seguidos de retrocruzamentos usando Saccharum officinarum como espécie genitora recorrente, podendo possuir apenas 5 a $10 \%$ do genoma nuclear das espécies parentais doadoras ( $\mathrm{Lu}$ et al., 1994). O resultado é um germoplasma com elevado nível de ploidia e de complexo comportamento meiótico, sendo talvez por isto, dentre os membros da família Poaceae, a espécie menos caracterizada do ponto de vista genético.

O conhecimento das relações filogenéticas das espécies e híbridos comerciais de cana-de-açúcar é fundamental para a organização, caracterização e conservação do 
germoplasma e, principalmente, para o uso do recurso genético existente em cruzamentos viáveis nos programas de melhoramento genético.

A avaliação molecular é uma forma eficiente de se estudar a partição da variabilidade genética entre as espécies cultivadas e seus parentais selvagens, esclarecendo suas relações filogenéticas e promovendo estratégias racionais para o melhoramento, coleta de germoplasma, conservação e utilização de recursos genéticos.

Os genes cloroplastidiais têm sido muito utilizados para reconstruir a filogenia em espécies relacionadas. Estudos recentes sobre a evolução do genoma do cloroplasto têm revelado um alto grau de conservação em tamanho, estrutura, conteúdo gênico e ordem linear dos genes entre espécies aparentadas. Além disso, a herança uniparental reduz o impacto da recombinação intermolecular e contribui para simplificar as teorias de evolução do ptDNA na maioria dos táxons vegetais. Este modo conservativo de evolução do ptDNA sugere que qualquer mudança em estrutura, arranjo ou conteúdo do genoma pode ter implicações filogenéticas significativas. Para aumentar a quantidade de informações disponíveis para a reconstrução filogenética, múltiplas regiões do cloroplasto têm sido analisadas, incluindo genes e espaçadores intergênicos.

A disponibilidade de seqüências completas de nucleotídeos de genomas cloroplastidiais de várias espécies torna possível utilizá-las em estudos evolutivos dos cloroplastos em plantas. A comparação estrutural dos plastomas fornece também elementos relacionados aos processos regulatórios da expressão gênica, destacando-se, quanto aos cloroplastos, a ocorrência de edição do mRNA, um processo de modificação pós-transcricional já descrito nos cloroplastos de várias espécies de plantas.

Os objetivos deste trabalho foram o sequenciamento de regiões específicas do genoma cloroplastidial de diferentes espécies e híbridos de cana-de-açúcar e de um cultivar de sorgo cujas seqüências não estavam disponiveis nos bancos de genes, e a análise comparativa das mesmas seqüências disponíveis dos plastomas de milho, arroz e trigo, espécies pertencentes à família Poaceae, para identificar sinais filogenéticos e regiões polimórficas pela avaliação de similaridades e divergências ao nível de nucleotídeos. 


\section{REVISÃO DE LITERATURA}

\subsection{Importância e Classificação Botânica da Cana-de-Açúcar}

A cana-de-açúcar é produzida em 130 países, sendo cultivada principalmente nas regiões tropicais e subtropicais. No Brasil ela é cultivada em quase 5,5 milhões de hectares sendo destinada, principalmente, à produção de açúcar e de álcool, à fabricação de aguardente e à alimentação de bovinos. $\mathrm{O}$ Brasil é líder na produção e exportação de derivados de cana-de-açúcar, bem como na utilização desta planta como fonte de energia líquida renovável (Matsuoka et al., 1999), apresentando extrema importância para a economia do Estado de São Paulo e para o país. Considerando a atual crise energética brasileira, a cultura também é relatada como promissora na produção de energia elétrica a ser extraída do bagaço da cana (Oliveira \& Vasconcelos, 2001).

De acordo com a entidade União da Agroindústria Canavieira de São Paulo (Única), na safra 2003/2004 o Brasil produziu 338,3 milhões de toneladas de cana-deaçúcar, com extensas áreas plantadas nas regiões Centro-Oeste, Sul (principalmente Paraná), Sudeste e Nordeste, sendo que a safra paulista atingiu 207,5 milhões de toneladas. O Estado de São Paulo é o maior produtor nacional, com cerca de 3,3 milhões

de hectares plantados. Segundo a entidade Única, somente neste estado o setor gera cerca de 300 mil empregos no campo e outros 90 mil na indústria (ÚNICA, 2004).

A cana-de-açúcar é uma planta alógama que pertence à família Poaceae, tribo Andropogoneae, gênero Saccharum. A família Poaceae é considerada uma das mais importantes famílias de plantas cultivadas, ocupando um terço das áreas terrestres do planeta, e inclui as culturas de cereais importantes na alimentação humana (Clayton \& 
Renvoize, 1986). A tribo Andropogoneae, a qual pertence à família Poaceae, é uma das maiores, mais especializadas (Celarier, 1956), e a mais definida taxonomicamente entre as tribos de gramíneas (Hartley, 1958; Clayton \& Renvoize, 1986). Esta tribo é dividida em três subtribos: Saccharinae/Germainiinae, a Sorghinae, e a Ischaeminae/Dimeriinae/Coicinae (Clayton \& Renvoize, 1986). A subtribo Saccharinae é tipicamente alta e higrófila, o que é considerada uma condição ecologicamente primitiva (Hartley, 1958). Dentre as Saccharinae, o 'complexo Saccharum' inclui os genótipos agronomicamente importantes de Saccharum spp., que são produtos freqüentemente obtidos de longos programas de melhoramento por cruzamentos entre $S$. officinarum, S. spontaneum e S. robustum (Grivet \& Arruda, 2002).

Mukherjee (1957) introduziu o termo 'complexo Saccharum' para representar o agrupamento dos gêneros Erianthus, Sclerostachya, Narenga, e Saccharum devido a uma coincidência geográfica na fronteira da região Indo-Burma-China, pela capacidade de produzir descendentes $F_{1}$ férteis, e pela observação do florescimento sincronizado em alguns dos arranjos coincidentes.

No gênero Saccharum ocorrem seis espécies: Saccharum officinarum L. $(2 \mathrm{n}=$ 80), $S$. robustum Brandes e Jeswit $(2 \mathrm{n}=60-205), S$. barberi Jeswit $(2 \mathrm{n}=81-124), S$. sinense Roxb $(2 \mathrm{n}=111-120)$, S. spontaneum L. $(2 \mathrm{n}=40-128)$ e $S$. edule Hassk $(2 \mathrm{n}=$ 60-80) (Daniels \& Roach, 1987). Os cultivares modernos são híbridos oriundos de cruzamentos entre $S$. officinarum e $S$. spontaneum seguidos de retrocruzamentos usando $S$. officinarum como espécie parental recorrente. O resultado é um germoplasma com elevado nível de ploidia, de complexo comportamento meiótico e que pode possuir até 5 a $10 \%$ do genoma das espécies parentais doadoras ( $\mathrm{Lu}$ et al., 1994). Uma compreensão da taxonomia e evolução do gênero Saccharum e seus parentais têm sido dificultados devido à ocorrência comum de poliploidia e pela reprodução vegetativa opcional.

\subsection{Centros de Origem de Espécies da Família Poaceae}

Estimativas baseadas em fósseis sugerem que a cana-de-açúcar e o sorgo divergiram de um ancestral comum a cinco milhões de anos atrás (Al-Janabi et al., 
1994), o arroz e o milho dividiram um ancestral comum aproximadamente a 45 - 55 milhões de anos atrás (Stebbins, 1981), as monocotiledôneas e dicotiledôneas divergiram entre 110 milhões (Dahlgren et al., 1985) e 200 milhões de anos atrás (Wolfe et al., 1989) e as plantas vasculares aparentemente divergiram entre 350 a 400 milhões de anos atrás (Wolfe et al., 1989). A divergência das espécies de cana-de-açúcar e sorgo ocorreu pelo acúmulo de mutações pouco consistentes (Kellogg \& Watson, 1993; Mason-Gamer et al., 1998; Spangler et al., 1999). Devido às considerações acima, as reconstruções filogenéticas da tribo Andropogoneae freqüentemente resultam em clados com baixo suporte interno, havendo poucos caracteres informativos para se obter uma topologia confiável (Spangler et al., 1999).

Apesar das espécies gramíneas de importância econômica dividirem ancestrais comuns a milhões de anos atrás, elas apresentam centros de origem distintos, sendo que a cana-de-açúcar é originária do continente asiático, mais especificamente na Índia. O sorgo, por sua vez, se originou provavelmente na África, embora algumas evidências indiquem que possa ter havido duas regiões de dispersão independentes: África e Índia (Empresa Brasileira de Pesquisa Agropecuária - EMBRAPA Milho e Sorgo, 2004). Há indicações de que a origem do milho tenha sido no México, América Central ou Sudoeste dos Estados Unidos (EMBRAPA Milho e Sorgo, 2004). Diversos historiadores e cientistas apontam o sudeste da Ásia como o local de origem do arroz, mais especificamente na Índia (EMBRAPA Arroz e Feijão, 2004). O centro de origem do trigo está localizado junto ao Oriente Médio e Ásia Menor (Irã, Iraque, Síria, Turquia e Israel) (EMBRAPA Trigo, 2004).

Sobral et al. (1994) demonstraram que os gêneros Saccharum e Sorghum possuem alta proximidade genética, apesar de o gênero Sorghum ter se dispersado da África, e o gênero Saccharum ter se estabelecido no sudeste asiático.

\subsection{Melhoramento Genético e Evolução}

O melhoramento genético da cana-de-açúcar aparece como base fundamental para se obter novas variedades para a manutenção e incremento no agronegócio 
brasileiro, mas pouco é conhecido sobre o nível de similaridade entre estas espécies e sobre a herança genética citoplasmática dos híbridos utilizados em plantios comerciais. $\mathrm{O}$ conhecimento das relações filogenéticas das espécies selvagens e híbridos comerciais é fundamental para a organização, caracterização e conservação do germoplasma e, principalmente, para orientar os programas de melhoramento genético utilizando os recursos genéticos existentes em cruzamentos viáveis.

Exemplos de espécies selvagens utilizadas nos cruzamentos para obtenção dos híbridos comerciais são: $S$. robustum (variedade Molokai 5099), S. spontaneum (variedade Krakatau), S. barberi Saretha (variedade Chunnee), S. officinarum (variedade Badila). Alguns dos híbridos comerciais obtidos em programas de melhoramento que visam à alta produtividade e a produção de açúcar são SP80-3280 (programa de melhoramento da Copersucar - Brasil), H72-1522 (programa de melhoramento do Havaí - EUA) e CP72-1210 (programa de melhoramento da Flórida - EUA). O híbrido POJ 2878 apresenta origem norte-americana e está presente na maioria das genealogias dos cruzamentos que deram origem aos híbridos comerciais em vários países, inclusive no Brasil.

Na espécie $S$. officinarum são encontradas as principais variedades comerciais utilizadas na produção de açúcar antes da existência dos programas de melhoramento. Geralmente, as variedades (híbridos clonais) desta espécie são denominadas "canas nobres" e apresentam alto teor de sacarose, baixo teor de fibra, colmos longos e grossos, boa despalha natural e alta produção nas condições de cultivo favorável (Pires, 1993).

Saccharum spontaneum é uma espécie altamente variável, pois sua distribuição geográfica é a mais ampla de todos os membros do gênero (Roach \& Daniels, 1987), seu número de cromossomos varia de $2 n=40$ a $2 n=128$ (Panje \& Babu, 1960), as isoenzimas e rDNA nuclear (sequiência de DNA codificador de RNA ribossômico) são as mais variáveis do gênero (Glaszmann et al., 1989, 1990), e tem uma ampla variação morfológica. A espécie $S$. spontaneum tem sido considerada primária dentro do gênero, e desta espécie, outras espécies como $S$. robustum e, ultimamente, $S$. officinarum foram derivadas, potencialmente pela introgressão com outros membros do complexo, durante a migração para o sul da fronteira Indo-Burma-China que foi postulada ser o centro de 
radiação e diversidade de Saccharum (Brandes et al., 1939; Roach \& Daniels, 1987). As espécies $S$. barberi e $S$. sinense foram derivadas de cruzamentos entre $S$. officinarum e $S$. spontaneum (Daniels \& Roach, 1987; Berding \& Roach, 1987).

Sobral et al. (1994) realizaram análises filogenéticas das mutações nos sítios de restrição enzimáticos do genoma cloroplastidial na subtribo Saccharinae da tribo Andropogoneae. A inferência filogenética sob várias pressuposições mostrou que as linhagens maternais de Narenga, Miscanthus, Sclerostachya, e Saccharum formaram um grupo monofilético, expondo poucas variações. O gênero Saccharum foi separado em dois clados por um único sítio de mutação: um contendo $S$. spontaneum, e o outro contendo todas as outras espécies de Saccharum e oito híbridos comerciais de várias regiões do mundo.

De acordo com Al-Janabi et al. (1994), dentro do complexo poliplóide Saccharum observa-se reduzido nível de variação nos genomas de cloroplasto e de mitocôndria. Neste caso, verificou-se a ausência de variação entre as variedades comerciais de cana-de-açúcar analisadas (híbridos de Saccharum), sugerindo a existência de uma monocultura citoplasmática mundial. Por outro lado, análises filogenéticas baseadas nos genomas nucleares e cloroplastidiais (plastomas) têm mostrado que $S$. spontaneum é a mais variável das espécies Saccharum e os genótipos de $S$. robustum e $S$. officinarum são muito relacionados. Devido a grande variabilidade de $S$. spontaneum, não se pode inferir que haja apenas um tipo de citoplasma (Burnquist, 1991).

\subsection{Características e Origem dos Plastídios}

As células vegetais contêm diversas organelas, entre elas os plastídios que estão presentes desde algas até angiospermas. Os plastídios se multiplicam por divisão e apresentam herança materna na maioria das espécies cultivadas (Leech et al., 1981; Scott \& Wilkinson, 1999). Eles contêm seu próprio sistema genético. A descoberta de um único DNA nos cloroplastos levou vários pesquisadores a estudarem a estrutura 
genômica e funções destas organelas (Palmer \& Stein, 1986; Kato et al., 2000; Martin et al., 2002; Leister, 2003).

As moléculas do DNA cloroplastidial (ptDNA) estavam entre as primeiras seqüenciadas devido ao seu tamanho pequeno e estrutura simples comparado aos genomas nucleares (Odintsova \& Yurina, 2003). Até maio de 2004, a estrutura primária dos DNAs plastidiais de 36 espécies de plantas superiores e algas foram determinadas (presentes no banco de dados do NCBI - National Center for Biotechnology Information, 2004). Isto promoveu evidências quanto à natureza conservada do DNA plastidial, até entre táxons pouco aparentados. De fato, a seqüência completa do genoma da cianobactéria Synechocystis sp. PCC6803 (Kaneko et al., 1996), representando o possível plastoma ancestral, promoveu evidências sobre os eventos evolucionários que levam nos dias atuais aos DNAs plastidiais, incluindo a transferência gênica para o núcleo e/ou mitocôndria e perda de gene.

De acordo com a origem endossimbionte, os plastídios descendem de determinadas cianobactérias fotossintetizantes, as quais foram eventualmente integradas ao interior de células eucarióticas primitivas, que provavelmente já haviam adquirido de maneira semelhante outras bactérias aeróbicas (ancestrais das mitocôndrias) (Baginsky \& Gruíssem, 2004). O resultado deste processo forneceu vantagens adaptativas ao eucarioto primitivo fotossintetizante, iniciando o processo evolutivo no qual se desenvolveram interações entre os compartimentos intracelulares cada vez mais específicas, capazes de permitir o estabelecimento e a diversidade dos organismos vegetais. A ordem cronológica e o número de eventos endossimbiontes cientificamente propostos ainda são questionados (Palmer, 1992). De acordo com Odintsova \& Yurina (2003), as análises filogenéticas de genes homólogos e a comparação da organização do grupo gênico em plastídios de eucariotos fotossintéticos e cianobactéria indicam que os plastídios apresentam uma origem monofilética, sendo derivados de um único ancestral cianobactéria. A observação de que os genomas plastidiais de diferentes plantas e algas contêm genes similares complementares também apóia a origem monofilética dos plastídios (Odintsova \& Yurina, 2003). 
O DNA cloroplastidial existe como uma molécula circular fechada de aproximadamente $150( \pm 30) \mathrm{kb}$ na maioria das plantas (Palmer \& Stein, 1986). Ele geralmente apresenta um par de regiões repetidas invertidas (seqüências convencionalmente denominadas $\mathrm{IR}_{\mathrm{A}} \mathrm{e} \mathrm{IR}_{\mathrm{B}}$ ), as quais são separadas por uma região de cópia única pequena (SSC) e uma região de cópia única grande (LSC). Alguns genes podem ser rearranjados nas suas posições relativas no plastoma, de acordo com a espécie (Kato et al., 2000).

A análise da estrutura e organização do genoma cloroplastidial de cana-de-açúcar (S. officinarum L.) foi realizado após o seu sequenciamento (Calsa Junior, 2001), fornecendo elementos para a análise de aspectos evolutivos e aplicações biotecnológicas (como a transformação do DNA cloroplastidial), que podem também ser útil para futuros estudos de regulação da expressão gênica. Pelas análises comparativas entre o plastoma de cana-de-açúcar (híbrido SP80-3280) e os de outras espécies, Calsa Junior (2001) observou que todos os grupos funcionais dos genes cloroplastidiais de milho foram localizados no plastoma de cana-de-açúcar, como também ycf's (genes putativos cloroplastidiais conservados - hypotetical chloroplast frames) deste plastoma e de outras espécies. Além disso, o pesquisador verificou maior identidade entre os plastomas de cana-de-açúcar e milho do que entre cana-de-açúcar e arroz com base na organização estrutural e na regulação da expressão gênica (edição de mRNA).

Os cloroplastos são organelas semi-autônomas, que dependem de uma grande quantidade de proteínas codificadas pelo núcleo que são importadas para dentro do plastídio depois de traduzidas no citossol. Os plastídios são essenciais para as funções celulares e abrigam uma maquinaria biossintética complexa para fixação de nitrogênio, biossíntese de aminoácidos, metabolismo sulfúrico, biossíntese de isoprenóides, e expressão gênica (Staehelin \& Newcomb, 2000). Martin et al. (2002) compararam 24.990 proteínas codificadas no genoma de Arabidopsis thaliana com três genomas de cianobactérias, o genoma de uma levedura, e 16 genomas de procariotos. Foram identificadas 9.368 proteínas conservadas para uma comparação de seqüência primária. Deste grupo de proteínas, considera-se que 1.700 proteínas são codificadas pelos genes que foram transferidos do plastídio para o núcleo. As proteínas das cianobactérias não 
retornaram de suas origens, mas foram distribuídas para diferentes localizações subcelulares no decorrer da evolução (Martin et al., 2002; Leister, 2003).

Durante a evolução, alguns genes foram transferidos dos cloroplastos para os núcleos. Os produtos destes genes são re-importados pelos cloroplastos com o auxílio dos peptídeos de trânsito e um mecanismo específico de importação de proteínas. Eventos similares ocorrem nas mitocôndrias, que também têm origem endossimbionte. Os plastídios contêm mais proteínas do que o ptDNA codifica, sendo que grande número de proteínas é importado. Pelo fato dos processos de regulação sob controle do núcleo serem mais complexos e inter-relacionados do que aqueles sob o controle das organelas, e devido às organelas naturalmente tenderem a estar sob controle dos genes reguladores nucleares, os processos regulatórios da organela estão provavelmente entre os primeiros a serem transferidos com sucesso para o núcleo (Herrmann, 1997).

\subsection{Regulação Gênica nos Cloroplastos}

Em plantas superiores, a estrutura genômica e a composição dos genes são altamente conservadas. Os plastomas codificam proteínas envolvidas na transcrição e tradução, assim como proteínas do aparato fotossintético e metabolismo fotossintético (Odintsova \& Yurina, 2003).

Os cloroplastos contêm genes para todas as espécies de $r R N A$, a maioria dos genes $t R N A$ plastidiais, genes para as subunidades da RNA-polimerase, muitas proteínas ribossomais e fatores traducionais. Em adição, eles codificam os componentes do aparato fotossintético incluindo a subunidade maior da ribulose-1,5-bisfosfato carboxilase/oxigenase (Rubisco), os componentes dos fotossistemas I e II (PS I e PS II), complexo citocromo $b_{6} f$, e ATP sintase. Uma das principais características dos plastomas é a presença de genes $n d h$ que codificam para as subunidades do complexo NADH desidrogenase da cadeia respiratória. Os genomas cloroplastidiais contêm um número de ORFs das quais algumas são conservadas ( $y c f s$ ) enquanto outras são espécie específicas. Assim originalmente 82 genes foram identificados no plastoma de tabaco 
(Shinozaki et al., 1986) e houve identificação de mais 24 genes (um gene que codifica para um RNA de baixo peso molecular e 23 genes que codificam proteínas) (Wakasugi et al., 1998), até este momento.

A expressão na forma de operon resulta em grandes transcritos primários policistrônicos processados para mRNA oligo e monocistrônico e sujeito a splicing e edição. A edição freqüentemente restabelece os resíduos de aminoácidos conservados nas proteínas correspondentes e assim representam uma função importante, eliminando os erros nas sequiências genômicas ao nível de mRNA. Segundo Odintsova \& Yurina (2003), a edição foi relatada para transcritos em todas as plantas superiores analisadas até o momento, mas não para algas e cianobactéria. Nos genomas mitocondriais, os eventos de edição ocorrem com mais freqüência do que nos cloroplastos (Odintsova \& Yurina, 2003). Pelo fato da edição modificar a informação armazenada no ptDNA, não é sempre possível prever a estrutura das proteínas codificadas pelo ptDNA para as seqüências gênicas. Além disso, a edição pode levar a formação de novas ORFs (Wakasugi et al., 2001; Odintsova \& Yurina, 2000).

A modificação pós-transcricional das moléculas de RNA nas organelas representa um nível principal de controle genético regulatório em células eucarióticas (Brennicke et al., 1999; Monde et al., 2000; Bock, 2000; Rochaix, 2001).

Até o momento foram identificados 27 diferentes sítios de edição em milho que afetam a expressão de 15 diferentes genes ( $a t p A, n d h A, n d h B, n d h D, n d h F, n d h G, r p o B$, rpoC2, rps8, rps14, rpl20, rpl2, petB, matK e $y c f 3$ ), observando-se maior transição na segunda posição do códon. Todos os eventos de edição são transições de $\mathrm{C}$ por $\mathrm{U}$ e, contrário à edição dos transcritos mitocondriais de plantas onde a transição geralmente é de $\mathrm{U}$ por $\mathrm{C}$, o que não é detectado para os transcritos de cloroplastos (Odintsova \& Yurina, 2003). As transições mais freqüentemente observadas (UCA para UUA e CCA para CUA) convertem os códons serina e prolina para o códon leucina. A perda do códon de iniciação do gene de milho rpl2 foi observada por Hoch et al. (1991), embora os eventos de edição geralmente ocorram nos códons internos dos mRNAs do cloroplasto, que são conservados ao nível de DNA em outras espécies (Maier et al., 1992). Por esta razão a edição pode também ser considerada como processo genético de 
reparo ao nível transcricional. Raramente a edição cria o códon de iniciação e terminação, e também ocorre nas regiões não traduzidas (5'-UTR) (Corneille et al., 2000). De acordo com Corneille et al. (2000), a edição do mRNA pode ser importante para alguns, mas não todos os sítios existentes, mesmo quando ocorre em genes essenciais. Um exemplo é a edição parcial do gene rpoB, cujos sítios estão localizados na região correspondente a um domínio não-essencial da subunidade $\beta$ da RNApolimerase plastidial.

$\mathrm{O}$ número de sítios de edição identificados e previstos até o momento nos transcritos dos genes cloroplastidiais de cana-de-açúcar, arroz, milho e trigo são, respectivamente, 23 presentes em 13 transcritos (Calsa Junior, 2001), 21 presentes em 11 transcritos, $27 \mathrm{em} 14$ transcritos e $28 \mathrm{em} 21$ transcritos (Odintsova \& Yurina, 2003).

\subsection{Análise Filogenética e Evolução dos Cloroplastos}

As análises filogenéticas de seqüências de DNA e proteínas se tornaram uma ferramenta importante para estudar a história evolutiva dos organismos desde bactérias até humanos. Desde que a taxa de evolução da seqüência varie extensivamente com o segmento do gene ou do DNA (Nei, 1987; Wilson et al., 1977), pode-se estudar a relação evolutiva em todos os níveis de classificação dos organismos (reinos, filos, classes, famílias, gêneros, espécies, e populações intraespecíficas). Análises filogenéticas são importantes também para esclarecer o modelo evolucionário das famílias de múltiplos genes que codificam proteínas nos genomas cloroplastidiais (Martin et al. 1998, 2002; Turmel et al., 1999, 2002; Adachi et al. 2000; Lemieux et al., 2000; De Las Rivas et al., 2002) assim como para compreender a evolução adaptativa ao nível molecular (Chandrasekharan et al., 1996; Jermann et al., 1995) e estudar a origem das endossimbioses primária e secundária (Delwiche, 1999; McFadden, 2001a). Esta técnica também fornece mais indícios sobre o mecanismo de manutenção dos alelos polimórficos nas populações (Takahata, 1993).

Segundo Matioli (2001), a reconstrução filogenética consiste em estimar as relações de ancestralidade para um determinado número de organismos (táxons). Uma 
árvore filogenética representa a história evolutiva dos organismos presentes nela. Nos métodos da máxima parcimônia, um dado grupo de seqüências de nucleotídeos (ou aminoácidos) é considerado, e as seqüências dos ancestrais para uma topologia hipotética são inferidas sob a suposição que as mudanças ocorrem em todas as direções entre os quatro nucleotídeos diferentes (ou 20 aminoácidos). $\mathrm{O}$ menor número de substituição de nucleotídeos que explica todo o processo evolutivo para uma dada topologia é então computada. Isto é realizado para todas as outras topologias, e a topologia que requerer o menor número de substituições é escolhida como a melhor árvore (Eck \& Dayhoff, 1966; Fitch, 1971).

Em plantas, os genomas do cloroplasto e da mitocôndria apresentam modelos diferentes de diferenciação genética comparado com os alelos nucleares devido aos seus meios de transmissão geralmente uniparental (Birky, 1988). Assim, para a compreensão da diferenciação populacional da planta e sua evolução, os três genomas interrelacionados devem ser considerados. O plastoma é altamente conservado e apresenta menor taxa de mutação do que os genomas nucleares (Wolfe et al., 1987; Clegg et al., 1994).

Segundo Odintsova \& Yurina (2003), as regiões repetidas invertidas (IRs) dos plastomas pertencem à região mais conservada da molécula contendo todos os rRNAs e os dois genes tRNA (tRNA ${ }^{\text {Ile }}$ (GAU) e tRNA ${ }^{\text {Ala }}$ (UGC)). As seqüências das IRs divergem duas a três vezes mais lentamente do que as seqüências únicas (SSC e LSC). As repetições constituem a estabilidade dos genomas cloroplastidiais, prevenindo a recombinação. A região de cópia única grande é a mais variável. O sequenciamento dos genomas cloroplastidiais de plantas superiores revelou as inversões, translocações, inserções/deleções de bases nitrogenadas até em espécies relacionadas, e permitiu identificar os "hotspots" de mutações. Assim, a comparação da estrutura do ptDNA em Oenothera elata (Hupfer et al., 2000) e algumas dicotiledôneas [tabaco (Shinozaki et al., 1986), A. thaliana (Sato et al., 1999), e espinafre (Schmitz-Linneweber et al., 2001)] demonstraram que elas diferem em uma grande inversão de $54 \mathrm{~kb}$ no LSC entre os genes $a c c D$ e rps 16 presentes em Oenothera. O plastoma de espinafre é $5.214 \mathrm{pb}$ menor que o ptDNA de tabaco. Isto resulta das regiões intergênicas que são mais curtas em 
comprimento nos segmentos das IRs e em todo o genoma. Na LSC de ptDNA de Lotus japonicus, uma inversão de $51 \mathrm{~kb}$ entre os genes $r b c L$ e $r p s l 6$ foi identificada. Uma inversão similar foi detectada no ptDNA de soja, sugerindo que é típica de legumes (Kato et al., 2000).

De acordo com Ingvarsson et al. (2003), inserções, deleções e inverções no genoma cloroplastidial de plantas superiores mostraram ser extremamente úteis para resolver as relações filogenéticas entre táxons proximamente relacionados e entre linhagens mais basais. Íntrons e espaçadores intergênicos do plastoma são muito usados nos estudos filogenéticos (Kelchner, 2000) e de genética de população (McCauley, 1995) de uma única espécie, sendo interessante saber se os indels (inserção e deleção de nucleotídeos) podem providenciar dados para aumentar a robustez dos estudos intraespecíficos.

Muitos processos moleculares são conhecidos por criarem indels, entre eles, o deslizamento da polimerase durante a replicação, conhecido por despareamento de fitas por deslizamento (Levinson \& Gutman, 1987), que adiciona ou remove pequenas seqüências repetidas, freqüentemente um ou poucos pares de base no comprimento. Indels grandes são freqüentemente associados com a formação de estruturas hairpins (Kelchner \& Wendel, 1996) ou stem-loop na estrutura secundária do DNA (Kelchner, 2000), e estes indels podem ou não apresentar similaridade na sequência com a região que flanqueia o sítio indel.

Seqüências de DNA do genoma cloroplastidial são amplamente utilizadas no campo da sistemática molecular vegetal. Comumente usados como marcadores moleculares cloroplastidiais para as análises filogenéticas em plantas, pode-se citar o gene matK (Johnson \& Soltis, 1994; Steele \& Vilgalys, 1994), ndhF (Olmstead \& Sweere, 1994), a região não-codificadora $\operatorname{trnL-F}$ (Taberlet et al., 1991), o espaçador $a t p B-r b c L$ (Setoguchi et al., 1997), o íntron rps16 (Downie \& Katz-Downie, 1999), região $\operatorname{trnC}$-trnD (Lee \& Wen, 2004). O DNA nuclear tem sido relativamente pouco explorado nos estudos de filogenia vegetal, com a exceção da região nuclear ribossomal do DNA, que foi seqüenciada em grande escala. Nesta região, especialmente os espaçadores transcritos internos (ITS1 e ITS2) são aplicados extensivamente para a 
reconstrução da filogenia em níveis taxonômicos inferiores. Entretanto, as seqüências ITS às vezes não são convenientes para os estudos filogenéticos, devido ao alto grau de divergência da seqüência (Wilson, 2003), às extensivas variações no comprimento entre cópias (Liston et al., 1996), aos problemas de paralogia (Baker et al., 2000), ou falta de robustez para resolução da filogenia (Whitcher \& Wen, 2001).

Segundo Lee \& Wen (2004), os marcadores cloroplastidiais para estudos em níveis taxonômicos inferiores são especialmente necessários, pois os dados da maioria dos plastomas herdados maternalmente podem fornecer importantes indícios sobre a hibridização e poliploidia, dois processos evolutivos comuns em plantas.

Dos estudos comparativos de todas as seqüências do ptDNA de arroz (família Poaceae) (Hiratsuka et al., 1989) com as de tabaco (família Solanaceae) (Shinozaki et al., 1986), seis tipos de alterações estruturais do plastoma foram identificados nos ptDNAs de gramíneas. Estas alterações são as seguintes: (1) três inversões (Hiratsuka et al., 1989) na região de cópia única grande (LSC), (2) perda de um íntron no gene rpoC1, (3) inserção de uma seqüência adicional no gene rpoC2 (Igloi et al., 1990; Shimada et al., 1990), (4) deleção das ORFs na região invertida repetida (Downie \& Palmer, 1992), (5) rearranjo do gene $a c c D$ (Ogihara et al., 1992), e (6) uma translocação não-recíproca do gene rpl23 para uma região montante (dowstream) de $r b c L$ (Bowman et al., 1988; Ogihara et al., 1988). Com a limitada exceção das mudanças estruturais, a ordem dos genes no ptDNA de tabaco é considerada como um padrão entre as angiospermas (Palmer et al., 1988).

Embora a estrutura genômica básica dos ptDNAs seja conservada na maioria das plantas superiores, algumas alterações estruturais foram encontradas nas comparações estruturais dos ptDNAs em plantas relacionadas. Drescher et al. (2000) verificaram diferenças em sequiências de polipeptídios homólogos codificados pelos cromossomos plastidiais de Atropa belladonna e tabaco, ocorrendo substituições de aminoácidos e, menos freqüentemente, inserções e deleções. Os oito códons não presentes no gene $a c c D$ de $A$. belladonna, que codifica a subunidade $\beta$ da acetil-CoA-carboxilase procariótica, ocorre numa região de baixa conservação entre as espécies vegetais. Inserções e deleções de nucleotídeos adicionais também foram encontradas nos genes $y c f l$ e $y c f 2$ de 
A. belladonna. Para $y c f 2$, as duas inserções encontradas em tabaco, uma delas com três códons em tamanho, a outra com oito códons, formam repetições diretas com os elementos da sequiência adjacente e estão também situados fora dos domínios altamente conservados (Drescher et al., 2000).

A natureza conservada do plastoma em plantas superiores (Wolfe et al., 1987) tem algumas implicações práticas para pesquisas genéticas. $O$ alto grau de conservação da seqüência tem facilitado o uso de sondas de hibridização heterólogas e primers na reação em cadeia da polimerase ( $\mathrm{PCR}$ ) em espécies não relacionadas, assim driblando a necessidade em clonar o DNA cloroplastidial de cada e todas as espécies sob estudo (Olmstead \& Palmer, 1994). Pares de primers de PCR universais foram construídos com base em seqüências codificadoras conservadas de genes do ptDNA e usados para amplificar o DNA localizado entre os sítios de ancoragem dos primers (Taberlet et al., 1991; Demesure et al., 1995; Dumolin-Lapegue et al., 1997). O sequenciamento direto ou análise de restrição dos produtos de PCR freqüentemente produziram polimorfismos informativos, que foram explorados para estudar a relação taxonômica e filogenética de vários níveis sistemáticos (Cipriani et al., 1995; Wolfe et al., 1997).

Chu et al. (2003) verificaram que os cloroplastos estão separados em dois grandes clados. Um deles corresponde às plantas verdes (clorófitas; Palmer \& Delwiche, 1998), que inclui todos os táxons com um cloroplasto, ambos com origem endossimbionte primária e secundária. $\mathrm{O}$ outro clado compreende as glaucófitas como Cyanophora e membros das rodófitas, que se referem a algas vermelhas e seus derivados simbióticos secundários (Palmer \& Delwiche 1998). As angiospermas estão separadas em dois clados correspondendo às monocotiledôneas e dicotiledôneas, os dois grandes clados obtidos com a filogenia de angiospermas (Crane et al., 1995), embora deveria ser observado que todas as monocotiledôneas incluídas na árvore são membros de uma única família (Poaceae). Uma simples análise de correlação dos genomas de cloroplasto completos proporcionou uma árvore que está de acordo com o conhecimento da origem dos cloroplastos e a relação filogenética de diferentes grupos de eucariotos fotossintetizantes como elucidado previamente pelas análises tradicionais dos genomas 
cloroplastidiais e outras aproximações moleculares e ultra-estruturais (Martin et al., 2002; De Las Rivas et al., 2002; Palmer \& Delwiche, 1998; McFadden, 2001a, b).

\subsection{Análise Comparativa de Plastomas da Família Poaceae}

Com o sequenciamento das bibliotecas plastômicas de Saccharum officinarum e a sua análise através do programa BLAST/NCBI (Altschul et al., 1990), demonstraramse elevada similaridade (acima de 97\%) com várias regiões dos plastomas de milho, arroz, cevada e trigo (Calsa Junior, 2001). Foi observado alto grau similaridade dos clones obtidos tanto com regiões intergênicas quanto codificadoras de operons cloroplastidiais relacionados com subunidades dos fotossistemas, ATPase, RNApolimerase plastidial, NADH-desidrogenase plastidial, ribulose-1,5-bisfosfatocarboxilase/oxigenase, proteínas ribossômicas, RNA ribossômico plastidial, RNA transportador plastidial, citocromo $\mathrm{b}_{6} \mathrm{f}$ e as ORF's (genes putativos) denominadas ORF 31 e ORF 48 (Calsa Junior, 2001).

Os membros da família Poaceae foram especialmente estudados quanto à divergência de seus plastomas e mutações no comprimento, sendo identificadas através da comparação de seqüências de nucleotídeos (Ogihara et al., 1988; Maier et al, 1995).

Segundo Calsa Junior (2001), a similaridade estrutural entre os plastomas de milho e cana-de-açúcar apresentam-se significativamente elevada, indicando que tanto regiões codificadoras como intergênicas são muito similares nestas duas espécies. Por outro lado, o plastoma de arroz se apresenta menos similar à cana-de-açúcar, sendo observada maior similaridade apenas nas regiões codificadoras.

Apesar do plastoma de milho apresentar conteúdo gênico e posição relativa dos genes idênticos aos do arroz, Maier et al. (1995) verificaram a presença de regiões localizadas de divergência nas regiões intergênicas. A região entre os genes trnI e trnL, pode refletir um evento de transferência gênica de $y c f 2$ para o núcleo, e a degradação do respectivo gene cloroplastidial resultando em fragmentos do mesmo; na região intergênica entre $r b c L$ e petA a divergência parece ocorrer devido à perda completa do gene plastidial $a c c D$ e à sua substituição funcional por um homólogo nuclear (Maier et 
al., 1995). As regiões referentes aos genes cloroplastidiais $y c f 2$ e $a c c D$, mostraram-se praticamente idênticas entre cana-de-açúcar e milho (Calsa Junior, 2001).

De acordo com Calsa Junior (2001), a região entre trnI e trnL do ptDNA de canade-açúcar apresenta uma identidade superior a $98 \%$ com a mesma região do plastoma de milho, indicando maior similaridade quanto a organização entre os plastomas de canade-açúcar e milho, assim como a divergência em relação ao plastoma de arroz.

As intersecções entre as duas regiões de repetição invertida $\left(\mathrm{IR}_{A}\right.$ e $\left.\mathrm{IR}_{\mathrm{B}}\right)$ e as duas regiões de cópia única (LSC e SSC) freqüentemente diferem entre os plastomas de várias espécies, sendo consideradas regiões polimórficas. Expansões e reduções do tamanho do plastoma são geralmente causadas por expansão ou redução das regiões de repetição invertida (Palmer, 1991). Existem estudos que mostram que todas as posições de intersecções podem variar inclusive entre os plastomas de espécies proximamente relacionadas tais como milho e arroz (Maier et al., 1995). Em milho o códon de iniciação do gene $n d h H$ é desfeito pela borda $\mathrm{IR}_{\mathrm{A}} / \mathrm{SSC}$ e SSC/IR $\mathrm{R}_{\mathrm{B}}$ está localizada dentro da região codificadora do gene $n d h F$. Em arroz a borda $\mathrm{IR}_{\mathrm{A}} / \mathrm{SSC}$ se desloca para dentro da região central do gene $n d h H$, ao passo que todo o gene $n d h F$ está dentro da região pequena de cópia única (SSC) (Maier et al., 1990).

Para reconstruir a filogenia da família Poaceae, subfamília Pooideae, Catalan et al. (1997) se basearam em seqüências do gene $n d h F$. Este gene é amplamente usado em estudos evolutivos de angiospermas, com a maior taxa de variabilidade exibida na segunda metade do gene (Kim \& Jansen, 1995; Catalan et al., 1997). Esta constatação colaborou para a família Poaceae pelo estudo de Clark et al. (1995), demonstrando que $60 \%$ das substituições de nucleotídeos e todos os gaps (deleções) no alinhamento estavam posicionados na extremidade 3' do gene, também relatado por Olmstead \& Sweere (1994) e Olmstead \& Reeves (1995) em Solanaceae e Scrophulariaceae. Além disso, este gene $(n d h F)$ apresenta duas vezes mais sítios variáveis e tamanho $50 \%$ maior do que o gene $r b c L$, que também é usado em análises filogenéticas, fornecendo assim mais caracteres informativos para estabelecer relações filogenéticas seguras (Olmstead \& Sweere, 1994; Kim \& Jansen, 1995). 
Dos cereais domesticados, o milho, o arroz e o trigo são os mais importantes para a população mundial. Taxonomicamente, tais espécies representam diferentes subfamílias da família Poaceae: Panicoideae (milho), Ehrhartoideae (arroz), e Pooideae (trigo). Tais espécies de cereais são modelos importantes para estudos evolutivos de gramíneas devido aos seus vários aspectos biológicos (Kellogg, 1998).

Comparando os plastomas de milho, arroz e trigo para obter implicações da diversidade gênica do cloroplasto e analisar filogeneticamente estes cereais, Matsuoka et al. (2002) verificaram que oito genes tRNAs, foram invariáveis para tais espécies. Além disso, os genes rRNAs se apresentam altamente conservados. Para inferir uma filogenia baseada em uma ampla comparação do genoma, tais pesquisadores focaram seus estudos nas substituições de nucleotídeos de 106 genes cloroplastidiais. Nas análises filogenéticas, sugere-se que o arroz e o trigo apresentam apenas um ancestral comum que não está envolvido com a linhagem que conduziu ao milho. Recentemente, Ogihara et al. (2002) sugeriram que o arroz e o trigo estão mais proximamente relacionados um ao outro do que com relação ao milho, baseando-se nas similaridades estruturais dos plastomas.

Muitos trabalhos que estudam a variação intraespecífica no ptDNA objetivam delinear a quantidade, localização geográfica e natureza genética da variação, freqüentemente por comparação de cultivares e parentais selvagens (Kochert et al., 1991). Análises de variação intraespecífica do ptDNA sugerem que o polimorfismo é comum, mas que o nível de variação depende da espécie analisada (Hong et al., 1993).

A diversidade do DNA cloroplastidial (ptDNA) foi verificada dentro e entre populações de cevada selvagem, Hordeum vulgare L. spp. spontaneum Koch de Israel e Iran. Três sítios de restrição polimórficos que definem três linhagens distintas de ptDNA foram detectadas (Neale et al., 1986). O ptDNA de Hordeum parece ter herança estritamente maternal, assim o polimorfismo do ptDNA reflete as linhagens maternais e a estrutura genética das populações de cevada reflete o fluxo gênico devido a dispersão da semente (Birky et al., 1983). A presença de variação no ptDNA dentro de espécies conduz a um ponto importante sobre as reconstruções filogenéticas da planta baseandose na variação dos fragmentos de restrição do ptDNA. 
Renno et al. (2001) estudaram a variação haplotípica do DNA cloroplastidial em seis espécies da seção Brevivalvula (Poaceae) de gramíneas poliplóides do complexo Pennisetum utilizando análises do polimorfismo do comprimento de fragmentos de restrição (RFLP) em 54 plantas correspondendo a 14 espécies elementares, cada uma caracterizada com base na morfologia e nível de ploidia. A variação no ptDNA foi geograficamente estruturada, sugerindo baixa dispersão entre locais, uma vez que a diversidade no haplotipo substancial observada nos locais pode indicar que a reprodução agâmica é responsável pela manutenção de distintos clones geneticamente isolados.

A evolução de gramíneas tem sido estudada principalmente por análise do grau de diversidade observado em estudos moleculares, morfológicos e citológicos (Kellogg, 1998). Embora as análises do ptDNA tenham contribuído significativamente para o conhecimento da evolução das gramíneas, a maioria das conclusões se baseiam na variação na seqüência de nucleotídeos em um único gene ou íntron tais como $r b c L$ (Doebley et al., 1990; Soltis et al., 1999; Soltis \& Soltis, 2000), $n d h F$ (Clark et al., 1995), rpoC2 (Cummings et al., 1994), rps4 (Nadot et al., 1994), matK (Hilu \& Alice, 1999), intron do gene rpl16 (Zhang, 2000). Em contraste aos amplos estudos realizados com enfoque baseado em um único gene, apenas poucos estudos enfocaram a evolução das gramíneas ou evolução do gene cloroplastidial de gramíneas se baseando em múltiplas seqüências de genes cloroplastidiais (Wolfe et al., 1987; Wolfe et al., 1989; Gaut \& Clegg, 1993). As alterações estruturais no ptDNA dos ancestrais dos cereais ocorreram simultaneamente (Katayama \& Ogihara, 1996; Ogihara et al., 2002). Assim, a variação na estrutura do ptDNA pode servir como um marcador filogenético (Odintsova \& Yurina, 2003).

Os objetivos deste trabalho foram o sequenciamento de regiões específicas do genoma cloroplastidial de diferentes espécies e híbridos de cana-de-açúcar e de um cultivar de sorgo cujas seqüências não estavam disponíveis nos bancos de genes e a análise comparativa das mesmas seqüências disponiveis dos plastomas de milho, arroz e trigo, espécies pertencentes à família Poaceae, para identificar sinais filogenéticos e regiões polimórficas pela avaliação de similaridades e divergências ao nível de nucleotídeos. 


\section{MATERIAL E MÉTODOS}

As atividades referentes à presente Dissertação foram desenvolvidas no Laboratório de Biologia Molecular, do Departamento de Ciência Biológicas da Escola Superior de Agricultura "Luiz de Queiroz", Universidade de São Paulo.

\subsection{Material Vegetal}

As diferentes espécies e híbridos de canas-de-açúcar utilizadas como material vegetal foram gentilmente fornecidas pelo Centro de Tecnologia Copersucar, PiracicabaSP e estão descritas na Tabela 1. As genealogias de algumas das variedades selecionadas estão presentes no Anexo A.

Tabela 1. Espécies e híbridos de cana-de-açúcar estudadas

\begin{tabular}{cc}
\hline ESPECIE & VARIEDADE \\
\hline Saccharum officinarum & Badila \\
Saccharum barberi Saretha & Chunnee \\
Saccharum spontaneum & Krakatau \\
Saccharum robustum & Molokai 5099 \\
SP71-1088 x H57-5028 & Híbrido SP80-3280 \\
POJ2364 x EK28 & Híbrido POJ2878 \\
CP65-357 x CP56-63 & Híbrido CP72-1210 \\
H59-3775 x H58-8019 & Híbrido H72-1522 \\
\hline
\end{tabular}


Segmentos nodais obtidos de plantas adultas cultivadas em campos experimentais da Copersucar foram trazidos ao laboratório e tratados por imersão em água destilada a $50^{\circ} \mathrm{C}$ durante 30 minutos, e subseqüente plantio em substrato comercial Plantimax (vasos contendo aproximadamente $1.000 \mathrm{~cm}^{3} /$ segmento nodal).

A espécie de sorgo (Sorghum bicolor) também foi estudada. Sementes de sorgo cultivar 822, gentilmente fornecidas pelo Departamento de Sementes da ESALQ/USP, foram semeadas em substrato comercial Plantimax.

Cana-de-açúcar e sorgo foram mantidos em casa-de-vegetação do Laboratório de Biologia Molecular.

\subsection{Isolamento do DNA}

Para a obtenção do DNA de cana-de-açúcar e sorgo, folhas jovens foram coletadas e imediatamente congeladas em nitrogênio líquido e maceradas em almofariz, e subseqüentemente utilizadas para extração de DNA plastidial ou DNA total.

\subsubsection{DNA cloroplastidial}

Para realizar o isolamento de cloroplastos intactos de folhas jovens de todas as espécies em estudos, utilizou-se o método do Triton X-100 (Mariac et al., 2000). A fração correspondente aos cloroplastos, obtida no método do Triton X-100, foi submetida ao isolamento do ptDNA. Para isto, utilizou-se o método aplicado à extração de DNA total de tecidos foliares descrito por Doyle \& Doyle (1990).

Após a obtenção da fração correspondente aos cloroplastos pelo método do Triton X-100, realizou-se o isolamento do ptDNA partindo da lise destas organelas. Para isto, estas organelas foram adicionadas de $500 \mu \mathrm{L}$ do tampão de extração de DNA [2 \% CTAB (p/v); $100 \mathrm{mM}$ Tris pH 8,0; $10 \mathrm{mM}$ EDTA pH 8,0;1,4 M NaCl; $1 \%$ 2-mercaptoetanol $(\mathrm{v} / \mathrm{v})]$ e incubadas a $55^{\circ} \mathrm{C}$ durante 10 minutos, e subseqüentemente incubadas em gelo por 1 minuto. Posteriormente, procedeu-se a uma extração com 
clorofórmio:álcool isoamílico (24:1 v/v), e a fase aquosa final foi adicionada de 0,1 volume de acetato de sódio $3 \mathrm{M}(\mathrm{pH}$ 5,2) e 1 volume de 2-propanol para a precipitação dos ácidos nucléicos $\left(-70^{\circ} \mathrm{C}\right.$ durante 1 hora $)$. Após centrifugação a $12.000 \times \mathrm{xg}\left(4^{\circ} \mathrm{C}, 30\right.$ minutos), o sedimento foi lavado em $0,5 \mathrm{~mL}$ de etanol $70 \%$, seco à temperatura ambiente durante 20 minutos e ressuspendido em $20 \mu \mathrm{L}$ de água destilada deionizada esterilizada (Calsa Junior, 2001).

\subsubsection{Extração de DNA Total}

Uma alternativa mais simples para obter o DNA molde para as reações de amplificação foi utilizar o método de extração de DNA total vegetal de Doyle \& Doyle (1990) ao invés da extração do DNA de cloroplasto. Esta metodologia foi possível, pois os pares de primers utilizados nestas reações foram desenhados em regiões conservadas do plastoma, além de serem específicos para as sequiências do cloroplasto em estudo.

\subsection{Identificação das Regiões dos Plastomas}

As regiões do plastoma selecionadas para verificar o grau de similaridade ou diversidade entre híbridos e espécies de cana-de-açúcar e posicioná-las evolutivamente com relação a outras espécies gramíneas de milho, arroz, trigo e sorgo, foram:

- Região $16 S$ rDNA (16S ribosomal DNA) que geralmente apresenta seqüência de nucleotídeos conservada nos plastomas.

- Região intergênica entre $r b c L$ (subunidade maior da ribulose-1,5-bisfosfatocarboxilase/oxigenase) e petA (citocromo f apoproteina). Esta região refere-se ao gene plastidial $a c c D$ (forma procariótica da acetil-CoA-carboxilase) que está presente no plastoma de algumas espécies e apresenta polimorfismo. 
- Região intergênica entre $\operatorname{trnI}$ e trnL (RNA transportador plastidial). Esta região pode refletir um evento de transferência gênica de $y c f 2$ para o núcleo, e a degradação do respectivo gene cloroplastidial, resultando em fragmentos do mesmo, dependendo das espécies.

- Um segmento das quatro intersecções do DNA cloroplastidial que ligam as duas regiões repetidas invertidas $\left(\mathrm{IR}_{\mathrm{A}}\right.$ e $\left.\mathrm{IR}_{\mathrm{B}}\right)$ com a região de cópia única grande (LSC) e a região de cópia única pequena (SSC). Nestas regiões buscou-se verificar a posição dos genes que se encontram nas intersecções ou próximos delas, os quais são: gene rpl22 (proteína ribossomal L22), $n d h H$ (NADH-Desidrogenase $\mathrm{H}$ ), $n d h F$ (NADHDesidrogenase F) e $p s b A$ (codifica a proteína D1 do fotossistema II presente no tilacóide).

\subsection{Reação em Cadeia da Polimerase (PCR) das Seqüências Alvo}

Devido à disponibilidade das sequiências de nucleotídeos dos plastomas de milho, arroz, trigo no banco de dados do National Center for Biotechnology Information (NCBI, 2004) (Tabela 2) e do plastoma de cana-de-açúcar (S. officinarum, variedade SP80-3280) na homepage Sugar Cane Chloroplast Genome Project (2004), realizou-se os alinhamentos das sequiências de nucleotídeos das regiões do cloroplasto em estudo utilizando o programa Vector NTI Suite v.6.0 (Informax Inc., USA). Posteriormente fezse a seleção de pares de primers específicos a serem utilizados no trabalho. Para isto, baseou-se nas seqüências flanqueadoras dos consensos (contigs) supostamente vizinhos das regiões alvo do ptDNA de cana-de-açúcar, considerando a homologia com o plastoma de milho, arroz e trigo para amplificação dos fragmentos entre os sítios de ancoragem dos primers por PCR.

Tabela 2. Plastomas de gramíneas estudadas

\begin{tabular}{lcc}
\hline Espécie & $N^{\circ}$ de acesso no NCBI & Referência \\
\hline Zea mays & $\mathrm{X} 86563$ & Maier et al., 1995 \\
Oryza sativa & $\mathrm{X} 15901$ & Hiratsuka et al., 1989 \\
Triticum aestivum & $\mathrm{AB} 042240$ & Ogihara et al., 2002 \\
\hline
\end{tabular}


Tanto o DNA total, como o DNA cloroplastidial foram utilizados nas reações de amplificação realizadas no aparelho PTC-100 (MJ Research Incorporation), utilizandose as seguintes condições: 10 pmoles/ $\mu \mathrm{L}$ dos primers forward e reverse; $5 \mathrm{mM}$ de dNTP; 10 ng de DNA; 0,3 U de enzima Taq DNA polimerase (Invitrogen Life Technologies), $3 \mu \mathrm{L}$ de tampão de reação 10X (Invitrogen Life Technologies) e 0,9 $\mu \mathrm{L}$ de $\mathrm{MgCl}_{2} 50 \mathrm{mM}$, em um volume final de $30 \mu \mathrm{L}$. Os pares de primers utilizados no trabalho (sintetizados pela Invitrogen Life Technologies) estão presentes na Tabela 3.

Tabela 3. Primers utilizados para amplificação de regiões de interesse do ptDNA

\begin{tabular}{|c|c|c|}
\hline $\begin{array}{c}\text { Região estudada e } \\
\text { tamanho do fragmento } \\
\text { esperado (pb) }\end{array}$ & Pares de Primers & $\begin{array}{c}\text { Posição no } \\
\text { plastoma da } \\
\text { cana-de-açúcar * }\end{array}$ \\
\hline $\begin{array}{l}16 S r D N A \\
(1.603 \mathrm{pb})\end{array}$ & $\begin{array}{l}\text { Forward: 5'-CCG AAT CCG CTT TGT CTA CG-3' } \\
\text { Reverse: 5'-TTG GGC GTG AAG CAG TGT C-3' }\end{array}$ & $\begin{array}{l}48.859-48.840 \\
47.256-47.274\end{array}$ \\
\hline $\begin{array}{c}16 S r D N A \\
\text { Interno } 1(890 \mathrm{pb})\end{array}$ & $\begin{array}{l}\text { Fonvard: 5'-GAG ACA CGG CCC AGA CTC C-3' } \\
\text { Reverse: 5'-TGT AGC ACG TGT GTC GCC C-3' }\end{array}$ & $\begin{array}{l}48.513-48.495 \\
47.623-47.641\end{array}$ \\
\hline $\begin{array}{c}\text { Intersecção } \mathrm{IR}_{\mathrm{A}} / \mathrm{SSC} \\
\text { gene } n d h H(1.650 \mathrm{pb})\end{array}$ & $\begin{array}{l}\text { Forward: 5'-AAG CTT CCA TCT GCT ATA GCT TGA AGC-3' } \\
\text { Reverse: 5'-GAG CTC GTT TGC TGG CTT ATT TGG C-3' }\end{array}$ & $\begin{array}{l}37.417-37.437 \\
39.064-39.046\end{array}$ \\
\hline $\begin{array}{l}\text { Gene } n d h H \\
\text { Interno } 1(1.007 \mathrm{pb})\end{array}$ & $\begin{array}{l}\text { Fonvard: 5'-CCC GGT GGA CGA ATT TTC C-3' } \\
\text { Reverse: 5'-GCA TGG TGT TCT TCG ACT G-3' }\end{array}$ & $\begin{array}{l}37.760-37.778 \\
38.767-38.749\end{array}$ \\
\hline $\begin{array}{l}\text { Intersecção } \mathrm{IR}_{\mathrm{A}} / \mathrm{LSC} \\
\text { gene } p s b A(1.627 \mathrm{pb})\end{array}$ & $\begin{array}{l}\text { Forward: 5'-AAG CTT GGT TGG CCA TAC AAT CGC GA-3' } \\
\text { Reverse: 5'-GAG CTC AAT TAT CTA CTC CAT CCG AC-3' }\end{array}$ & $\begin{array}{l}61.439-61.458 \\
63.065-63.046\end{array}$ \\
\hline $\begin{array}{c}\text { Gene } p s b A \\
\text { Internol }(712 \mathrm{pb})\end{array}$ & $\begin{array}{l}\text { Forward: 5'-GCA GTG AAC CAG ATC CCT AC-3' } \\
\text { Reverse: 5'-ATC GCC TTC ATC GCT GCT CC-3' }\end{array}$ & $\begin{array}{l}61.920-61.939 \\
62.632-62.613\end{array}$ \\
\hline $\begin{array}{l}\text { Intersecção LSC/IR } \\
\text { gene } r p l 22(827 \mathrm{pb})\end{array}$ & $\begin{array}{l}\text { Forward: 5'-AAG CTT GGT TGT GCG AAC CAA AAG GA-3' } \\
\text { Reverse: 5'-GGT ACC TGG CCA TAC AAT CGC GAT TC-3' }\end{array}$ & $\begin{array}{l}2.853-2.872 \\
3.678-3.659\end{array}$ \\
\hline $\begin{array}{l}\text { Intersecção SSC/IR } \\
\text { gene } n d h F(2.872 \mathrm{pb})\end{array}$ & $\begin{array}{l}\text { Forward: 5'-TCT AGA CAC CAA TAA GAT ACG GAG AC-3' } \\
\text { Reverse: 5'-GGT ACC ATT ACG AAA CAA CAG AGC TC-3' }\end{array}$ & $\begin{array}{l}25.957-25.976 \\
28.829-28.810\end{array}$ \\
\hline $\begin{array}{c}\text { Gene } n d h F \\
\text { Interno } 1(2.146 \mathrm{pb})\end{array}$ & $\begin{array}{l}\text { Forward: 5'-GAT AAG ACG ATA TTC GCC CTC-3' } \\
\text { Reverse: 5'-AGA AGA GGA ATT ACC CAG GCA-3' }\end{array}$ & $\begin{array}{l}26.309-26.329 \\
28.435-28.455\end{array}$ \\
\hline $\begin{array}{c}\text { Gene } n d h F \\
\text { Interno } 2(1.108 \mathrm{pb})\end{array}$ & $\begin{array}{l}\text { Forward: 5'-CCC GTT TCA TGA GGA TAG ACA-3' } \\
\text { Reverse: 5'-CCA ATT GCA GCG AGT GCT TGT-3' }\end{array}$ & $\begin{array}{l}26.863-26.883 \\
27.971-27.951\end{array}$ \\
\hline
\end{tabular}


Tabela 3. Primers utilizados para amplificação de regiões de interesse do ptDNA

\begin{tabular}{|c|c|c|}
\hline $\begin{array}{l}\text { Região estudada e } \\
\text { tamanho do fragmento } \\
\text { esperado (pb) }\end{array}$ & Pares de Primers & $\begin{array}{c}\text { Posição no } \\
\text { plastoma da } \\
\text { cana-de-açúcar* }\end{array}$ \\
\hline $\begin{array}{l}\text { Entre genes } r b c L \text { e } \text { petA } \\
(5.848 \mathrm{pb})\end{array}$ & $\begin{array}{l}\text { Forward: 5'-AGG ATA GAA CGT ACA CAG GG-3' } \\
\text { Reverse: 5'-TGC ATG AGA TAG AAA TAA GG-3' }\end{array}$ & $\begin{array}{l}118.873-118.892 \\
124.813-124.794\end{array}$ \\
\hline $\begin{array}{l}\text { Entre } r b c L \text { e petA } \\
\text { Interno } 1(5.253 \mathrm{pb})\end{array}$ & $\begin{array}{l}\text { Forward: 5'-CCG CCT GAA GAA GCA GGA GC-3' } \\
\text { Reverse: 5'-ATC CGA CGC ATC CAC TAT GGA-3' }\end{array}$ & $\begin{array}{l}119.227-119.246 \\
124.480-124.460\end{array}$ \\
\hline $\begin{array}{l}\text { Entre } r b c L \text { e petA } \\
\text { Interno } 2(4.377 \mathrm{pb})\end{array}$ & $\begin{array}{l}\text { Forward: 5'-CGG TAG AGC GTG TTA TGA GTG-3' } \\
\text { Reverse: 5'-AGC AGT GCT TCC TGA TAC TGT-3' }\end{array}$ & $\begin{array}{l}119.637-119.657 \\
123.994-124.014\end{array}$ \\
\hline $\begin{array}{l}\text { Entre } r b c L \text { e petA } \\
\text { Interno } 3(3.453 \mathrm{pb})\end{array}$ & $\begin{array}{l}\text { Forward: 5'-CCG GTA } \\
\text { Reverse: 5'-CAA GTG }\end{array}$ & $\begin{array}{l}120.065-120.085 \\
123.518-123.498\end{array}$ \\
\hline $\begin{array}{l}\text { Entre } r b c L \text { e petA } \\
\text { Interno } 4(2.542 \mathrm{pb})\end{array}$ & $\begin{array}{l}\text { Forward: 5'-GCC GCA GCT TGT GAA } \\
\text { Reverse: 5'-CGG ATT GCC TGG TAT }\end{array}$ & $\begin{array}{l}120.448-120.467 \\
122.990-122.972\end{array}$ \\
\hline $\begin{array}{l}\text { Entre } r b c L \text { e petA } \\
\text { Interno } 5(1.759 \mathrm{pb})\end{array}$ & $\begin{array}{l}\text { Forward: 5'-CAT TGG GTC GAA CTC TTC TT-3' } \\
\text { Reverse: 5'-GAT CTA AAT GGA GTG GAA TAG A-3' }\end{array}$ & $\begin{array}{l}120.912-120.931 \\
122.671-122.650\end{array}$ \\
\hline $\begin{array}{l}\text { Entre } r b c L \text { e petA } \\
\text { Interno } 6(770 \mathrm{pb})\end{array}$ & $\begin{array}{l}\text { Forward: 5'-GAG ACA CAT ATT CTA TGA C } \\
\text { Reverse: 5'-CGA ATC GGT CAT AAC CAC I }\end{array}$ & $\begin{array}{l}121.444-121.464 \\
122.214-122.196\end{array}$ \\
\hline $\begin{array}{l}\text { Entre genes } \operatorname{trnl} \text { e } \operatorname{trnL} \\
\qquad(4.043 \mathrm{pb})\end{array}$ & $\begin{array}{l}\text { Forward: 5'-CGA GTT CTT ATT GTT } \\
\text { Reverse: 5'-TCG AAG CTA TTT GA' }\end{array}$ & $\begin{array}{l}59.217-59.197 \\
55.171-55.190\end{array}$ \\
\hline $\begin{array}{l}\text { Entre } \operatorname{trn} I \text { e } \operatorname{trn} L \\
\text { Interno } 1(3.397 \mathrm{pb})\end{array}$ & $\begin{array}{l}\text { Forward: 5'-GGA TTG AAC AAC CGA GAT CCA-3', } \\
\text { Reverse: 5'-GGA GGT TCG AGT CCT CTT CAA-3' }\end{array}$ & $\begin{array}{l}58.766-58.746 \\
55.369-55.389\end{array}$ \\
\hline $\begin{array}{l}\text { Entre } \operatorname{trn} I \text { e } \operatorname{trn} L \\
\text { Interno } 2(2.578 \mathrm{pb})\end{array}$ & $\begin{array}{l}\text { Forward: 5'-CGA GGC CCT ATC CAT TAG TAT-3' } \\
\text { Reverse: 5'-GCG AAT CCC TGT TTG TAT CCT-3' }\end{array}$ & $\begin{array}{l}58.312-58.292 \\
55.754-55.734\end{array}$ \\
\hline $\begin{array}{l}\text { Entre } \operatorname{trn} I \text { e } \operatorname{trn} L \\
\text { Interno } 3(1.559 \mathrm{pb})\end{array}$ & $\begin{array}{l}\text { Forward: 5'-CGG TCC GAA CCA AGG AAT C-3', } \\
\text { Reverse: 5'-GGT GAC TTA CCC ATT CAG TGA-3' }\end{array}$ & $\begin{array}{l}57.796-57.778 \\
56.237-56.257\end{array}$ \\
\hline $\begin{array}{l}\text { Entre } \operatorname{trn} I \text { e } \operatorname{trn} L \\
\text { Interno } 4(590 \mathrm{pb})\end{array}$ & $\begin{array}{l}\text { Forward: 5'-CAG GCC TTT GTC TCT GTG T-3' } \\
\text { Reverse: 5'-GGC AGT TCA TAT CAT CCC ATA-3' }\end{array}$ & $\begin{array}{l}57.316-57.298 \\
56.726-56.746\end{array}$ \\
\hline
\end{tabular}

*Variedade de cana-de-açúcar SP80-3280, espécie Saccharum officinarum

(http://sucest.lad.dcc.unicamp.br/sc-chloroplast/). As bases nitrogenadas em negrito são sítios de restrição para a clonagem em vetor $p B S$.

A amplificação foi realizada nas condições: $94^{\circ} \mathrm{C}$ por 2 minutos; 35 ciclos constituídos de desnaturação a $94^{\circ} \mathrm{C}$ por 45 segundos, anelamento a temperatura adequada para o par de primers por 30 segundos e extensão a $72^{\circ} \mathrm{C}$ por tempo variando com o tamanho da sequiência a ser amplificada (para cada $1 \mathrm{~kb}$ foi utilizado 1 minuto); extensão final a $72^{\circ} \mathrm{C}$ por 10 minutos; e finalização a $4^{\circ} \mathrm{C}$. As amostras dos produtos de amplificação foram armazenadas a $-20^{\circ} \mathrm{C}$. Para verificar a quantidade de DNA amplificado e confirmar a amplificação, amostras dos produtos da PCR (10\% do 
volume total da amostra amplificada) foram analisadas em gel de agarose $0,8 \%$ (TAE $\left.1 \mathrm{x}, 3 \mathrm{~V} . \mathrm{cm}^{-1}\right)$. Os resultados serviram para quantificar o DNA para as reações de sequenciamento.

\subsection{Clonagem de Seqüências Alvo}

A clonagem das regiões alvo do ptDNA no vetor $p B S$ (Plasmid Blue Script cloning vector) foi realizado nos casos em que as seqüências de DNA cloroplastidial apresentaram dificuldade no sequenciamento de produtos de PCR ou produziram seqüências de baixa qualidade. A região que inclui o gene $n d h F$ (NADH-desidrogenase F), localizado na intersecção de $\mathrm{SSC}_{\mathrm{e}} \mathrm{IR}_{\mathrm{B}}$ do plastoma de todas as espécies e híbridos de cana-de-açúcar e do cultivar 822 de sorgo em estudo, foi clonada.

Os fragmentos de $2.872 \mathrm{pb}$, obtidos das diferentes espécies e híbridos de canade-açúcar e do cultivar de sorgo, foram purificados com o kit GFX PCR DNA Purification (Amersham Biosciences, Cat.N. 27-9602-01) de acordo com o fabricante. Em seguida foi realizado o reparo das extremidades do DNA usando: $16 \mu \mathrm{L}$ do produto de PCR purificado, $1 \mu \mathrm{L}$ de Klenow Fragment, $2 \mu \mathrm{L}$ de 10X Blunting/Kinasing Buffer, 1 $\mu \mathrm{L}$ de Polynucleotide Kinase, obtendo um volume final de $20 \mu \mathrm{L}$. Tal reação foi incubada a $37^{\circ} \mathrm{C}$ por 30 minutos. Realizou-se novamente a purificação dos fragmentos de DNA reparados nas extremidades com o mesmo kit citado acima. Em seguida, fez-se a ligação do inserto no vetor, utilizando $15 \mu \mathrm{L}$ de DNA (500 a $1.000 \mathrm{ng}$ ), $1 \mu \mathrm{L}$ de vetor pBS desfosforilado (50 ng. $\mu \mathrm{L}^{-1}$ ), $4 \mu \mathrm{L}$ de $2 X$ Ligation Buffer, $1 \mu \mathrm{L}$ de solução de DTT, 1 $\mu \mathrm{L}$ de $T_{4} D N A$ Ligase. As reações de ligação foram incubadas a $14^{\circ} \mathrm{C}$ por 18 horas. Células competentes de Escherichia coli (cepa DH5 $\alpha$ ) foram transformadas por choque térmico a $42^{\circ} \mathrm{C}$ por 45 segundos. Para a recuperação das células bacterianas transformadas, foi adicionado $900 \mu \mathrm{L}$ de meio $\mathrm{LB}$, incubando a $37^{\circ} \mathrm{C}$ por 1 hora sob agitação. As transformações foram distribuídas em placas de Petri contendo meio de cultura LB sólido, substrato X-Gal $\left(50 \mathrm{mg} \cdot \mathrm{mL}^{-1}\right)$ / IPTG $(100 \mathrm{mM})$ e antibiótico 
ampicilina $\left(100 \mu \mathrm{g} \cdot \mathrm{mL}^{-1}\right)$ e depois incubadas a $37^{\circ} \mathrm{C}$ durante a noite. Foram realizadas mini-preparações de colônias selecionadas utilizando o método da lise alcalina, proposto por Birboim \& Doly (1979). Para identificar clones contendo o inserto, foram feitas digestões com a enzima de restrição XhoI (fragmento esperado: $5.836 \mathrm{pb}$ ) e com as enzimas XhoI e XbaI (fragmentos esperados: 2.971 pb e 2.901 pb), cujos sítios de restrição estão presentes apenas no vetor $p B S$. O DNA plasmidial dos clones obtidos foram armazenados a $-20^{\circ} \mathrm{C}$. A quantidade e integridade do DNA foram verificadas através da eletroforese de uma alíquota (10\% do volume de eluição do sedimento pellet - obtido na mini-preparação) em gel de agarose $0,8 \%$ (TAE 1x, 3 V.cm ${ }^{-1}$ ), também para quantificação do DNA para reação de sequenciamento.

\subsection{Sequenciamento}

As amostras amplificadas por PCR e os plasmídios isolados que apresentaram os insertos esperados foram utilizados como molde na reação de sequenciamento a qual se baseou nos protocolos fornecidos pelo fabricante do kit utilizado (Applied Biosystems, kit BigDye ${ }^{T M}$ Terminator Cycle Sequencing v3.0, Cat.N. 4314419), em seqüenciador automático ABI-3100 (Applied Biosystems). Estas reações foram realizadas em microplacas para termocicladores (96 poços, $200 \mu \mathrm{L} /$ poço), seguindo-se as coordenadas de posição das amostras. Os plasmídios foram seqüenciados com primer Forward (5'CCC AGT CAC GAC GTT GTA AAA CG-3') ou Reverse (5’-AGC GGA TAA CAA TTT CAC ACA GG-3') e no caso dos DNAs produtos de PCR, utilizou-se primer Forward ou Reverse específico de cada região amplificada por PCR (ver Tabela 3, item 3.4). A quantidade de DNA adicionada variou de acordo com a fonte de DNA utilizada (DNA de dupla fita ou produto de PCR) e o tamanho do fragmento a ser seqüenciado. A Tabela 4 apresenta a quantidade de amostra de DNA (ng) a ser utilizada em cada reação de sequenciamento. 
Tabela 4. Quantificação de amostras de DNA para reação de sequenciamento

\begin{tabular}{ccc}
\hline Tipo de amostra & Tamanho do Fragmento $(p b)$ & Quantidade (ng) \\
\hline Produto de PCR & $100-200$ & $1-3$ \\
& $200-500$ & $3-10$ \\
& $500-1.000$ & $5-20$ \\
& $1.000-2.000$ & $10-40$ \\
& $>2.000$ & $40-100$ \\
DNA dupla fita & independe & $200-500$ \\
\hline
\end{tabular}

Antes de realizar o sequenciamento, cada microplaca foi incubada a $95^{\circ} \mathrm{C}$ por 3 minutos para que as amostras de DNA fossem desnaturadas, e imediatamente incubou-se no gelo para evitar a renaturação.

Os programas de coleta (ABI-Prism Collection, Applied Biosystems) e de análise (Sequencing Analysis, Applied Biosystems) dos sinais emitidos pelo seqüenciador geram os cromatogramas e as seqüências de nucleotídeos referentes a cada amostra seqüenciada. Os cromatogramas são representações gráficas da intensidade da fluorescência emitida por cada nucleotídeo do DNA seqüenciado, e indicam a confiabilidade dos dados obtidos durante o sequenciamento.

\subsection{Análise das Seqüências}

Os programas apresentados a seguir foram utilizados nas análises das seqüências de nucleotídeos do plastoma selecionadas para o estudo [16S rDNA, rpl22 (IR $\mathrm{B} / \mathrm{LSC}$ ), $\left.n d h H\left(\mathrm{IR}_{\mathrm{A}} / \mathrm{SSC}\right), n d h F\left(\mathrm{SSC}_{\mathrm{IR}}\right), p s b A\left(\mathrm{LSC}_{\mathrm{B}}\right) \mathrm{IR}_{\mathrm{A}}\right)$, regiões intergênicas entre $r b c L$ e petA e entre trnI e trnL] tendo em vista identificar marcadores filogenéticos ou hotspots no DNA cloroplastidial através da análise comparativa destas seqüências dos híbridos e 
espécies de cana-de-açúcar (Saccharum spp.) e de outras espécies gramíneas como sorgo, milho, arroz e trigo, e posicionar filogeneticamente todas as espécies estudadas:

- NCBI / Entrez / Nucleotide (National Center of Biotechnology Information, USA) (acesso http://www.ncbi.nlm.nih.gov/entrez/query.fcgi?db=Nucleotide): utilizado para buscar as sequiências das regiões em estudo das espécies Poaceae de milho (número de acesso: X86563), arroz (número de acesso: X15901) e trigo (número de acesso: $\mathrm{AB} 042240$ ).

- Vector NTI Suite v.6.0 (Informax Inc., USA): utilizado para o alinhamento das seqüências.

- Algoritmo Phred-Phrap-Consed (Ewing et al., 1998; Ewing \& Green, 1998; Gordon et al., 1998): software para produção do cromatograma processado, realização do agrupamento de sequiências e montagem de contíguos genômicos - permite edição de bases e verificação da qualidade das sequiências.

- BLAST/NCBI (Basic Local Alignment Search Tool - National Center of Biotechnology Information, USA) (Altschul et al., 1990) (acesso na homepage http://www.ncbi.nlm.nih.gov/entrez/BLAST/): programa utilizado para verificar a existência de similaridade entre o DNA cloroplastidial das espécies e híbridos de canade-açúcar e as outras espécies, como sorgo, milho, trigo e arroz.

- MultiAlin (Multiple Sequence Alignment) (Corpet, 1988) (acesso: http://prodes.toulouse.inra.fr/multalin/multalin.html): utilizado para analisar o alinhamento de seqüências de nucleotídeos, em que o resultado obtido foi salvo no formato de BOXSHADE. Para tal, copiou-se o formato FASTA da análise feita no programa MultiAlin e inseriu-se no programa BOXSHADE (acesso: http://www.ch.embnet.org/software/BOX_form.html). 
- BioEdit Sequence Alignment Editor (Hall, 1999) (acesso: http://www.mbio.ncsu.edu/BioEdit/bioedit.html). Para realizar os alinhamentos múltiplos e obter as matrizes que foram material para as análises filogenéticas, utilizouse o programa acessório ClustalW (Thompson et al., 1994), o qual faz o alinhamento se baseando em distância. Tal programa ocorre em duas etapas: a) Pairwise (aos pares) todas as seqüências são comparadas par a par e uma medida da similaridade máxima entre cada duas seqüências é calculada. Para calcular essa medida de similaridade máxima, uma matriz de pontos é construída onde seus dois eixos representam as duas sequiências comparadas. Com base nessa matriz de pontos, o programa irá maximizar a similaridade entre as seqüências, usando para isto as penalidades (penalidade de intervalo que é o número de bases idênticas que devemos adicionar para inserir um intervalo e a penalidade de substituição); b) O programa de alinhamento múltiplo começa alinhando primeiro as seqüências mais semelhantes, em seguida as que se conectam a estas e, assim por diante, até que todas as seqüências estejam alinhadas.

\section{- PAUP*4.0b10 (Phylogenetic Analysis Using Parsimony and Other Methods)} (Swofford, 2003) (acesso: http://paup.csit.fsu.edu/): utilizado nas análises filogenéticas, havendo disponibilidade de três métodos: máxima parcimônia, likelihood (probabilidade ou verossimilhança) e distância.

O método selecionado foi o da parcimônia que considera que a mutação indel (evento que envolve deleção ou inserção nucleotídica, verificado através da comparação de cadeias nucleotídicas homólogas com comprimentos diferentes) ocorre com menor frequiência do que a mutação do tipo substituição de nucleotídeos. É a adoção da hipótese mais simples.

Para testar o grau de confiabilidade das árvores filogenéticas foi selecionado o teste de bootstrap (Felsenstein, 1985). A técnica do bootstrap revela a consistência interna dos dados, ou seja, se a topologia muda muito conforme a reamostragem dos dados. Este procedimento é usado para verificar a proporção de vezes em que uma determinada estimativa ocorre além de um limite pré-estabelecido através de sorteios repetidos, com reposição, dos dados originais. De acordo com Schneider (2003), 
considera-se como bootstrap significativo (robusto) valores acima de $95 \%$, independente da repetibilidade. Já valores moderados (70 - $94 \%$ ou fracos (51 - 69\%), se repetidos com vários marcadores diferentes, poderiam ser considerados como indicativos de suporte para o clado (representação gráfica de um grupo monofilético $\rightarrow$ grupo constituído de uma espécie ancestral e todos os seus descendentes).

- TreeView (acesso: http://taxonomy.zoology.gla.ac.uk/rod/treeview.html), programa desenvolvido por Page (1996): utilizado para disponibilizar as árvores filogenéticas resultantes das análises desenvolvidas no programa $P A U P * 4.0 b 10$.

\subsection{Análise Comparativa de Edição de mRNA por RT-PCR}

Para obter dados que auxiliem nas análises de filogenia foi realizada a análise de edição do mRNA dos genes $y c f 3, n d h A, n d h B, n d h D, n d h F, r p o B, r p o C 2, r p s 8, r p s 14$, rpl20, rpl2, petB e atpA de sorgo (Sorghum bicolor cv 822), milho e cana-de-açúcar. Desde que os sítios de edição para cana e milho estão disponíveis (Maier et al., 1995; Calsa Jr., 2001), o sequenciamento de cDNA foi realizado somente para o sorgo. Os primers que amplificam as regiões de edição foram desenhados com base nas seqüências de nucleotídeos dos genes apresentados acima dos plastomas de milho e cana-de-açúcar os quais estão descritos na Tabela 5. 
Tabela 5. Primers para análise de edição de mRNA no plastoma de sorgo

\begin{tabular}{|c|c|c|c|}
\hline $\begin{array}{l}\text { Pares de } \\
\text { Primers }\end{array}$ & Seqüência (5' - 3') & $\operatorname{Tm}\left({ }^{\circ} \mathrm{C}\right)$ & $\begin{array}{c}\text { Posição no Plastoma } \\
\text { de milho } \\
\end{array}$ \\
\hline$y c f .3(\mathrm{R})$ & TCATTGATAAGACCTCCTCG & 44,6 & $46.167-46.148$ \\
\hline$y c f 3(\mathrm{~F})$ & GAAGGGGTTTCGTTCTAGCG & 48,7 & $46.148-45.167$ \\
\hline$n d h B(\mathrm{R})$ & AGACCTAGCAGCTAAAAGAG & 44,6 & $\begin{array}{c}89.228-89.247 \\
133.515-133.496\end{array}$ \\
\hline$n d h B(\mathrm{~F})$ & GTGGTGCTAACGATTTAATA & 40,5 & $\begin{array}{c}91.045-91.026 \\
131.698-131.717\end{array}$ \\
\hline $\operatorname{rpoc2}(\mathrm{R})$ & CGTGTGATAAATTCTTTGAG & 40,5 & $29.913-29.894$ \\
\hline rpoc2 (F) & GATATTCATTTTCCTGAAGA & 38,5 & $29.599-29.618$ \\
\hline $\operatorname{pet} B(\mathrm{R})$ & CCCTATAACGGACCCGAAAT & 46,7 & $74.548-74.529$ \\
\hline$p e t B(\mathrm{~F})$ & ACCCCGTGAATTAACTTGGG & 46,7 & $74.234-74.253$ \\
\hline$n d h D(\mathrm{R})$ & GGGGAAGCGCATTACAGTAC & 48,7 & $110.929-110.910$ \\
\hline$n d h D(\mathrm{~F})$ & GTGTAGCACCGATAAATCCA & 43,8 & $110.611-110.630$ \\
\hline$r p l 2(\mathrm{R})$ & CCACTTCTAGATAGAGAAAC & 42,6 & $\begin{array}{c}84.462-84.443 \\
138.281-138.300\end{array}$ \\
\hline$r p l 2(\mathrm{~F})$ & CCATCCCCATAGTGTATGAG & 46,7 & $\begin{array}{c}84.128-84.147 \\
138.615-138.596\end{array}$ \\
\hline$n d h A(\mathrm{R})$ & TTCTTACTGTTATTGTATTC & 36,4 & $114.322-114.341$ \\
\hline$n d h A(F)$ & GGGTAGAGGTAGAAACTATC & 44,6 & $116.444-116.425$ \\
\hline $\operatorname{atp} A(\mathrm{R})$ & GGTGTTTACGTAACTCATCC & 44,6 & $37.965-37.946$ \\
\hline $\operatorname{atp} A(\mathrm{~F})$ & GCGGATCTATTCAATGCCGG & 46 & $37.611-37.630$ \\
\hline$r p o B(\mathrm{R})$ & CCTAATTCACATTTTTGTTG & 38,5 & $22.237-22.218$ \\
\hline$r p o B(\mathrm{~F})$ & ATACCGAATTGTGATCAATC & 40,5 & $21.815-21.834$ \\
\hline$r p s 14(\mathrm{R})$ & AAAGTTTGATTCAGAGGGAG & 42,6 & $38.964-38.945$ \\
\hline$r p s 14(\mathrm{~F})$ & CTTGTTGCACCCGGTAACAA & 46,7 & $38.676-38.695$ \\
\hline
\end{tabular}


Tabela 5. Primers para análise de edição de mRNA no plastoma de sorgo

\begin{tabular}{cccc}
\hline $\begin{array}{c}\text { Pares de } \\
\text { Primers }\end{array}$ & Seqüência $\left(5^{\prime}-3^{\prime}\right)$ & Tm $\left({ }^{\circ} \mathrm{C}\right)$ & $\begin{array}{c}\text { Posição no } \\
\text { Plastoma de milho }\end{array}$ \\
\hline$n d h F(\mathrm{R})$ & TACATATCAATATGCCTGGG & 42,6 & $107.283-107.264$ \\
$n d h F(\mathrm{~F})$ & GAACTAAGATTCCTACAGTA & 40,5 & $106.970-106.989$ \\
$r p l 20(\mathrm{R})$ & CAAAAATGCGTTCATTTGCC & 42,6 & $68.587-68.568$ \\
$r p l 20(\mathrm{~F})$ & CCTTTAATTGATGATCCTTA & 38,5 & $68.268-68.287$ \\
$r p s 8(\mathrm{R})$ & ACTGTTCGAGTAGTATCCAC & 44,6 & $78.835-78.816$ \\
$r p s 8(\mathrm{~F})$ & CTTCTCCCCCAATTCTGTTT & 44,6 & $78.511-78.530$ \\
\hline
\end{tabular}

Tm: Temperatura melting (temperatura de anelamento do primer).

*Primers R: reverse; F: forward.

Ao realizar a comparação das seqüências genômicas e dos respectivos cDNAs destes genes, é possível detectar os eventos de edição do mRNA nos cloroplastos de sorgo, devido à ocorrência de substituição de uma base nitrogenada citosina (C) por outra uracila $(\mathrm{U})$ nos sítios de edição.

\subsubsection{Extração de RNA total}

O material foliar coletado de sorgo (cultivar 822, obtido conforme item 3.1) foi imediatamente congelado em nitrogênio líquido e triturado em almofariz. Pequenas quantidades foram transferidas para tubos de microcentrífuga de $1,5 \mathrm{~mL}$ até atingir a marca de aproximadamente $0,1 \mathrm{~mL}$ para o isolamento de RNA total com o reagente Trizol (Gibco-BRL), de acordo com o método recomendado pelo fabricante. O RNA isolado foi analisado em gel de agarose $1 \%$ (TBE $1 \mathrm{x}$ tratado com DEPC $0,01 \%$, $3 \mathrm{~V} . \mathrm{cm}^{-1}$ ). Aproximadamente $5,0 \mu \mathrm{g}$ do RNA total foram tratados com Amplification grade DNAse I livre de RNAse (Invitrogen Life Technologies), de acordo com as instruções do fabricante. O tratamento do RNA total com DNAse I é indicado para 
eliminar possíveis contaminações com DNA genômico, o que pode comprometer a amplificação correta da seqüência dos cDNAs.

\subsubsection{Síntese do cDNA}

O RNA total foi utilizado para a síntese do cDNA total foliar de sorgo, obtido através do kit SuperScript ${ }^{T M}$ Preamplification System (Invitrogen Life Technologies), tendo os hexâmeros randômicos do kit como primers.

Para verificar a possível presença de DNA plastômico contaminante, primers foram desenhados para amplificação da região editada em transcritos dos genes $n d h A$, $n d h B$ e $y c f 3$ (ORF 170), que possuem íntron, sendo que cada primer se localiza em um éxon diferente, permitindo a distinção por tamanho dos produtos amplificados a partir do cDNA (sem íntron) e a partir do DNA contaminante (com íntron). Tais primers se encontram na Tabela 5 (item 3.8).

O cDNA total foi usado como molde para a amplificação dạ região de interesse com os primers presentes na Tabela 5, via PCR convencional: $94^{\circ} \mathrm{C}$ por 2 minutos; 35 ciclos de desnaturação a $94^{\circ} \mathrm{C}$ por 45 segundos, anelamento a temperatura adequada para o par de primers por 30 segundos e extensão a $72^{\circ} \mathrm{C}$ por tempo variando com o tamanho da sequiência a ser amplificada (para cada $1 \mathrm{~kb}$ foi utilizado 1 minuto); extensão final a $72^{\circ} \mathrm{C}$ por 10 minutos; e finalização a $4^{\circ} \mathrm{C}$. Como controle, realizou-se a amplificação das mesmas regiões usando como molde o DNA total de sorgo.

Uma alíquota referente a $10 \%$ do volume de cada produto de RT-PCR foi analisada em gel de agarose $1 \%$ (TAE $1 \mathrm{x}, 3 \mathrm{~V} \cdot \mathrm{cm}^{-1}$ ), e, após a verificação do tamanho esperado para cada produto de amplificação, estes foram utilizados como molde para a reação de sequenciamento (ver item 3.6).

Posteriormente, o alinhamento das seqüências de nucleotídeos foi analisado através dos programas Vector NTI Suíte v.6.0 (Informax Inc., USA) e ClustalW (programa acessório do BioEdit). 


\section{RESULTADOS E DISCUSSÃO}

\subsection{Material Vegetal}

A metodologia utilizada para propagação vegetativa de segmentos nodais de plantas adultas cultivadas em campo das diferentes espécies e híbridos de cana-deaçúcar apresentou-se adequada. Observou-se que o brotamento de folhas ocorreu após o período de aproximadamente sete dias do plantio, sendo as plantas mantidas em casa-devegetação. As folhas entre 5,0 e $20,0 \mathrm{~cm}$ de comprimento são mais favoráveis ao isolamento de cloroplasto e do seu DNA, além da extração de DNA total, o que pode ocorrer devido à menor quantidade de fibras e sílica no tecido foliar.

O material vegetal de sorgo foi obtido após cinco dias da germinação de suas sementes. As folhas de sorgo selecionadas para realizar o isolamento de cloroplasto e do seu DNA e a extração de DNA total apresentaram entre 5,0 e 15,0 cm de comprimento. O tecido vegetal de sorgo apresenta menos fibras e sílica do que o tecido vegetal de cana-de-açúcar, o que facilita as etapas de extração de DNA cloroplastidial e DNA total de suas folhas.

\subsection{Isolamento do DNA dos Cloroplastos}

O método do Triton X-100 (Mariac et al., 2000) selecionado para o isolamento de cloroplastos de folhas jovens das espécies e híbridos de cana-de-açúcar e do cultivar de sorgo, seguido pela extração do ptDNA utilizando o método de extração de DNA total (Doyle \& Doyle, 1990), forneceu resultados adequados em relação à integridade e 
pureza do DNA cloroplastidial. O método do Triton X-100 se baseia na composição lipídica diferencial entre as membranas do cloroplasto e a carioteca, principalmente em relação aos constituintes glicerolipídicos. A composição lipídica das membranas do cloroplasto também difere das membranas do retículo endoplasmático e das mitocôndrias (Taiz \& Zeiger, 1998). As membranas da carioteca, do retículo endoplasmático e das mitocôndrias não apresentam galactosildiacilgliceróis e sulfolipídios os quais estão presentes nas membranas do cloroplasto.

\subsection{Extração de DNA Total}

Com o desenvolvimento do projeto, optou-se pela extração de DNA total vegetal (método descrito por Doyle \& Doyle, 1990) de folhas jovens das espécies e híbridos de cana-de-açúcar e do cultivar de sorgo ao invés da extração do DNA de cloroplasto, pois os pares de primers utilizados nas reações de PCR são específicos para as seqüências de cloroplasto em estudo. O método de extração de DNA total vegetal mostrou-se mais eficiente devido ao menor tempo dispensado para o seu isolamento, comparado com o método de extração de DNA cloroplastidial. O rendimento médio de DNA total obtido foi de $20 \mu \mathrm{g} / \mathrm{g}$ de tecido foliar.

\subsection{Clonagem de Sequiências Alvo}

Após verificar a dificuldade no sequenciamento de produtos de PCR da região que inclui o gene $n d h F$ de todas as espécies e híbridos de cana-de-açúcar e do cultivar 822 de sorgo em estudo, optou-se por realizar a clonagem desta região alvo no vetor $p B S$ (Plasmid Blue Script cloning vector). No total foram obtidos 54 clones incluindo todas as espécies e híbridos de cana-de-açúcar e o cultivar de sorgo, havendo, em média, cinco clones de cada um deles. 


\subsection{Sequenciamento dos Clones e Produtos de PCR}

Foram completamente seqüenciadas as seguintes regiões: $16 S \operatorname{rDNA}$, intersecção entre $\mathrm{IR}_{\mathrm{A}}$ e SSC correspondendo ao gene $n d h H$, intersecção entre $\mathrm{IR}_{\mathrm{A}}$ e LSC correspondendo ao gene $p s b A$, intersecção entre $\operatorname{LSC}$ e $\operatorname{IR}_{\mathrm{B}}$ correspondendo ao gene $r p l 22$, intersecção entre $\mathrm{SSC}$ e $\mathrm{IR}_{\mathrm{B}}$ correspondendo ao gene $n d h F$, regiões intergênicas entre $r b c L$ e $p e t A$ e entre $t r n I$ e $t r n L$. Todas essas seqüências apresentaram alta qualidade quando analisadas pelo programa Phred/Phrap/Consed o qual fez o alinhamento (clustering) das mesmas, formando as seqüências consenso (contigs). O comprimento em pares de base (pb) das seqüências alvo analisadas encontra-se no Tabela 6.

Tabela 6. Comprimento das seqüências alvo analisadas em pares de base

\begin{tabular}{|c|c|}
\hline Região do ptDNA & Comprimento em pares de base \\
\hline $16 S r D N A$ & $\begin{array}{l}1.497 \text { (todas espécie e híbridos de cana, o } \\
\text { cultivar de sorgo, milho, arroz e trigo) }\end{array}$ \\
\hline \multirow{4}{*}{ Intersecção $\mathrm{IR}_{\mathrm{A}} / \mathrm{SSC}$ - gene $n d h H$} & 1.564 (todas espécies e híbridos de cana) \\
\hline & 1.546 (sorgo e milho) \\
\hline & 1.550 (arroz) \\
\hline & 1.557 (trigo) \\
\hline \multirow[t]{5}{*}{ Intersecção $\mathrm{IR}_{\mathrm{A}} / \mathrm{LSC}$ - gene $p s b A$} & $\begin{array}{l}1.531 \text { (todas espécies e híbridos de cana, } \\
\text { exceto Krakatau) }\end{array}$ \\
\hline & 1.530 (S. spontaneum - Krakatau) \\
\hline & 1.529 (sorgo) \\
\hline & 1.524 (milho e arroz) \\
\hline & 1.542 (trigo) \\
\hline \multirow[t]{4}{*}{ Intersecção LSC/IR $\mathrm{B}_{\mathrm{B}}$ - gene $r p l 22$} & 722 (todas espécies e híbridos de cana) \\
\hline & 724 (sorgo e milho) \\
\hline & 697 (arroz) \\
\hline & 690 (trigo) \\
\hline
\end{tabular}


Tabela 6. Comprimento das seqüências alvo analisadas em pares de base

\begin{tabular}{|c|c|}
\hline Região do ptDNA & Comprimento em pares de base \\
\hline \multirow[t]{7}{*}{ Intersecção SSC/IR - gene $n d h F$} & $\begin{array}{c}2.800 \text { (Híbridos de cana: SP80-3280, } \\
\text { H72-1522, POJ2878, CP72-1210) }\end{array}$ \\
\hline & 2.801 (S. robustum - Molokai 5099) \\
\hline & $\begin{array}{l}2.798 \text { (S. spontaneum, S. barberi Saretha, } S . \\
\text { officinarum - Badila) }\end{array}$ \\
\hline & 2.762 (sorgo) \\
\hline & 2.784 (milho) \\
\hline & 2.981 (arroz) \\
\hline & 2.919 (trigo) \\
\hline \multirow{6}{*}{$\begin{array}{l}\text { Região intergênica entre } \\
\qquad \operatorname{trnI} \text { e } \operatorname{trn} L\end{array}$} & $\begin{array}{l}3.888 \text { (todas espécies e híbridos de cana, } \\
\text { exceto Krakatau) }\end{array}$ \\
\hline & 3.882 (S. spontaneum - Krakatau) \\
\hline & 3.887 (sorgo) \\
\hline & 3.885 (milho) \\
\hline & 1.762 (arroz) \\
\hline & 1.761 (trigo) \\
\hline \multirow{7}{*}{$\begin{array}{l}\text { Região intergênica entre } \\
\qquad r b c L \text { e petA }\end{array}$} & $\begin{array}{l}5.674 \text { (todos espécies e híbridos de cana, } \\
\text { exceto } S \text {. robustum e } S \text {. spontaneum) }\end{array}$ \\
\hline & 5.670 (S. robustum - Molokai 5099) \\
\hline & 5.672 (S. spontaneum - Krakatau) \\
\hline & 5.616 (sorgo) \\
\hline & 5.582 (milho) \\
\hline & 6.485 (arroz) \\
\hline & 5.690 (trigo) \\
\hline
\end{tabular}

Embora a estrutura completa do plastoma seja conservada por estabilização das repetições invertidas longas, alterações estruturais nos plastomas, tais como inversões (Howe et al., 1988; Hiratsuka et al., 1989), translocações (Ogihara et al., 1988), e deleções de bases nitrogenadas (Palmer, 1991), são encontradas entre as angiospermas. Além disso, análises de seqüência dos DNAs cloroplastidiais em plantas relacionadas tem permitido a identificação de "hotspots" para mutações em comprimento (Ogihara et 
al., 1988), e este enfoque comparativo é importante para a compreensão dos mecanismos de evolução do plastoma.

Ao analisar o comprimento das seqüências alvo presentes na Tabela 6, observase que realmente a região $16 S \mathrm{~S} D N A$ dos plastomas estudados apresenta-se muito conservada, não havendo mutações que resultem no polimorfismo de comprimento. As regiões repetidas invertidas (IRs) dos plastomas pertencem à região mais conservada da molécula contendo todos os rRNAs e os genes tRNAs (Odintsova \& Yurina, 2003). As outras seqüências alvo analisadas apresentam variações no comprimento entre as espécies estudadas, havendo diferenças nos números de pares de bases. As intersecções do plastoma que correspondem aos genes $n d h H, p s b A, r p l 22$ e $n d h F$ mostram-se aproximadamente iguais em todas as espécies, havendo variações em alguns pares de base. A região codificadora dos genes $n d h H, p s b A, r p l 22$ apresentam poucas inserções e deleções de bases nitrogenadas (indels) (dados não apresentados). A intersecção entre $\mathrm{SSC}$ e $\mathrm{IR}_{\mathrm{B}}$ que corresponde ao gene $n d h F$ apresenta alguma variação no comprimento, variando de $2.762 \mathrm{pb}$ (sorgo) a $2.981 \mathrm{pb}$ (arroz). Estas variações se devem aos indels, além de ocorrer mutações do tipo transição e transversão. Catalan et al. (1997) se basearam em sequiências do gene $n d h F$ para realizar estudos evolutivos de angiospermas, apresentando maior taxa de variabilidade na segunda metade do gene. Isto pode ser observado no Anexo B que apresenta o alinhamento das seqüências da região que inclui o gene $n d h F$ das espécies estudadas.

A região intergênica entre $\operatorname{trn} I$ e $\operatorname{trn} L$ apresenta polimorfismo no comprimento (Tabela 6), sendo que tal região é menor nas espécies de arroz e trigo quando comparada com a mesma região intergênica de cana, sorgo e milho (Figura 1). Este resultado já foi observado por Maier et al. (1995) que sugeriu que esta região reflete um evento de transferência gênica de $y c f 2$, presente em tabaco (Figura 1), para o núcleo, e a degradação do respectivo gene cloroplastidial, resultando em fragmentos do mesmo, dependendo das espécies. A eliminação do $y c f 2$, que apresenta um tamanho de $2.181 \mathrm{pb}$ para cada região invertida repetida $\left(\mathrm{IR}_{\mathrm{A}}\right.$ e $\left.\mathrm{IR}_{\mathrm{B}}\right)$, é mais avançada nos plastomas de arroz e trigo. De acordo com Maier et al. (1995), a fragmentação do ycf2 provavelmente 
reflete diferentes estágios de deleção do gene após sua função original ter sido assumida por uma cópia do gene $y c f 2$ transferida para o genoma nuclear. Geralmente o evento de transferência gênica é considerado como a principal razão para a redução no tamanho do genoma da bactéria endossimbionte original para os genomas dos cloroplastos atuais (Palmer, 1991; Gray, 1991). Assim, os fragmentos remanescentes do ycf2 ainda observados nos plastomas das espécies analisadas provavelmente promovem um exemplo representativo dos estágios de transição da deleção do gene cloroplastidial, que se acredita ter ocorrido durante a evolução dos plastomas. 
Tabaco

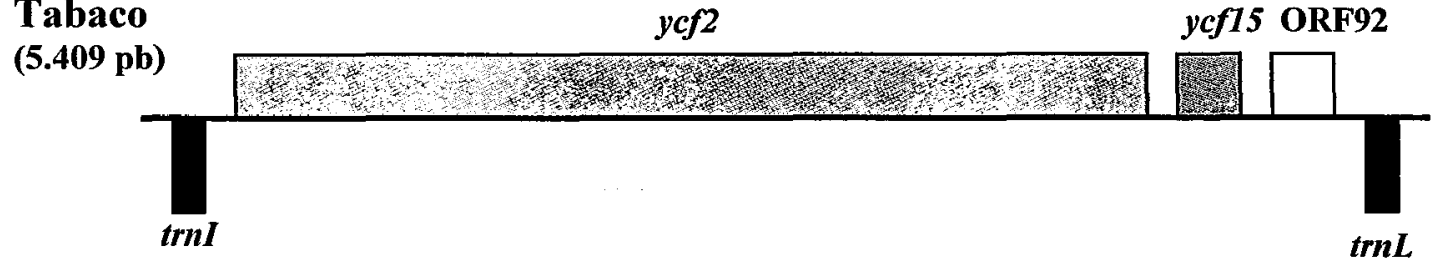

Milho

(3.885 pb) ORF46

ORF139

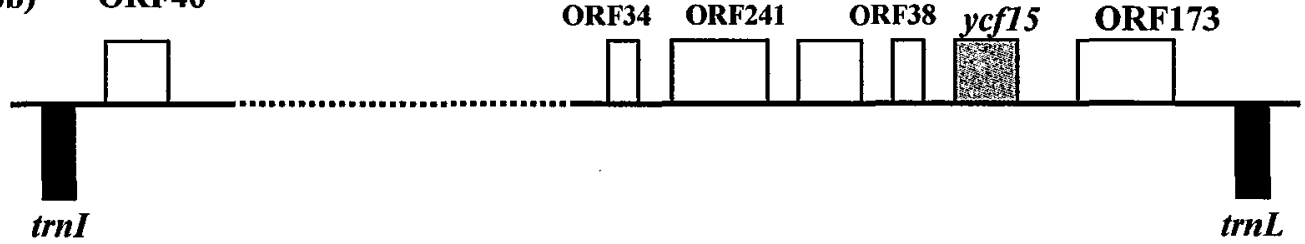

Cana-de-açúcar*

(3.888 pb)

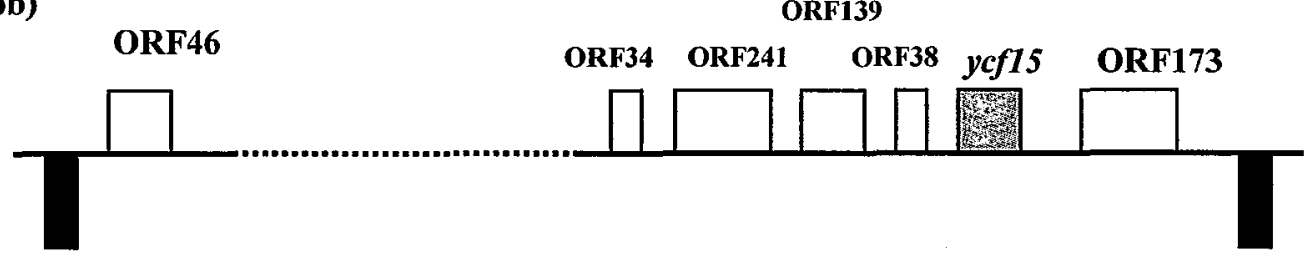

Sorgo

trnI

$\operatorname{trn} L$

(3.887 pb) ORF46

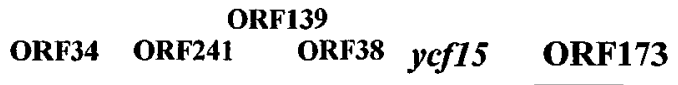

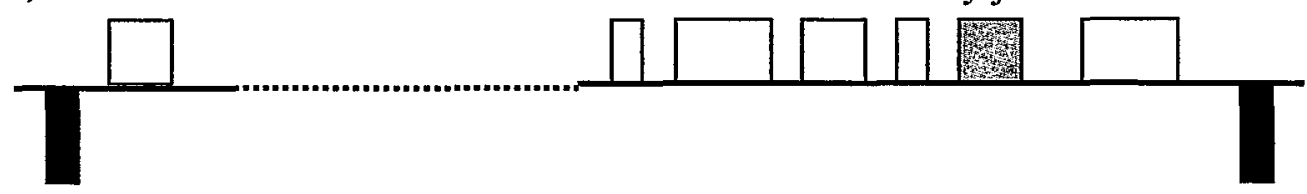

Arroz

(1.762 pb) ORF46

ORF34 ORF28 ORF64

ORF249

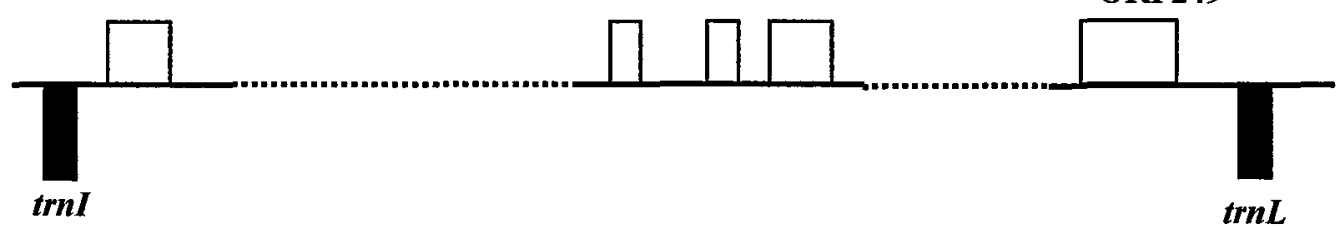

Trigo

(1.761 pb) ORF46

ORF34 ORF28 ORF64

ORF249

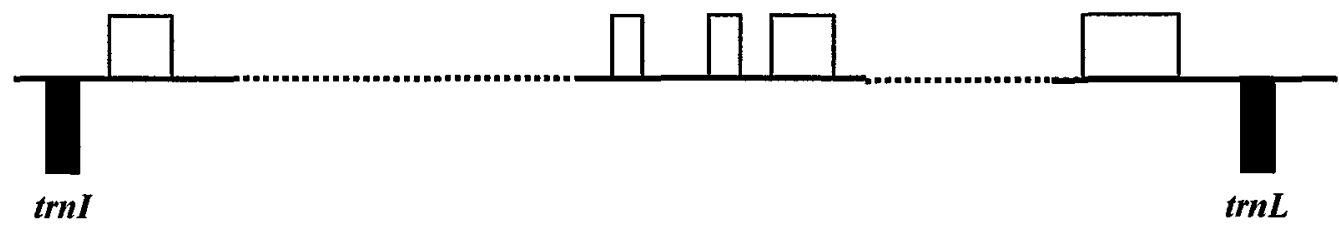

Figura 1 - Variação entre os plastomas de plantas terrestres na região intergênica trnI-trnL. Linhas tracejadas representam deleções no grupo Poaceae. *S. spontaneum apresenta $3.882 \mathrm{pb}$ 
A região intergênica entre $r b c L$ e petA está localizada na região de cópia única grande (LSC) e apresenta polimorfismo no comprimento (Tabela 6), sendo que o arroz apresenta tamanho maior (6.485 pb) do que as outras espécies estudadas (Figura 2). Esta região refere-se ao gene plastidial $a c c D$ (forma procariótica da acetil-CoA-carboxilase) que foi reduzido para um quadro de leitura de apenas 106 códons (ORF106) no plastoma de arroz e está ausente nos plastomas de cana-de-açúcar, sorgo, milho e trigo. De acordo com Maier et al. (1995), a completa deleção nestas espécies sugere que a ORF106 em arroz representa um estágio intermediário na degradação do gene $a c c D$. Tal gene parece ter sido completamente perdido em cana-de-açúcar, sorgo, milho e trigo, havendo substituição da função deste gene organelar por um gene codificado pelo genoma nuclear de origem eucariótica. 


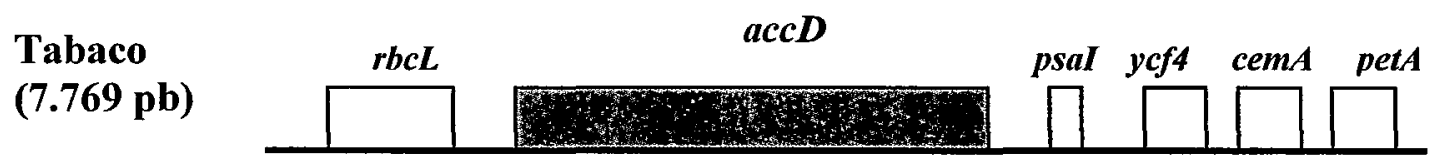

Arroz

$(6.485 \mathrm{pb})$

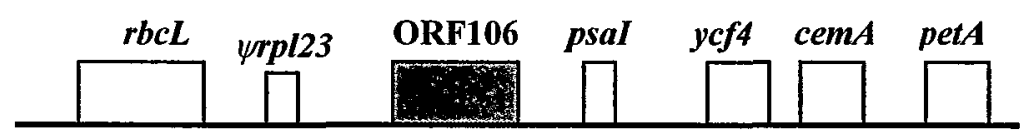

Trigo

$(5.690 \mathrm{pb})$

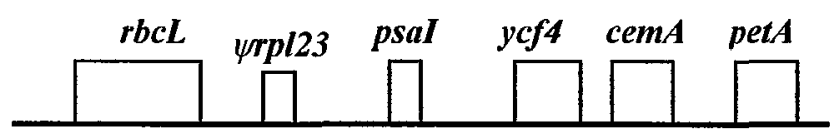

Sorgo

$(5.616 \mathrm{pb})$

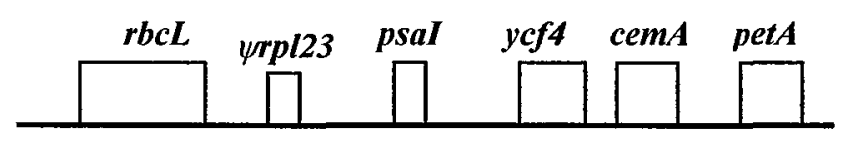

Milho

$(5.582 \mathrm{pb})$

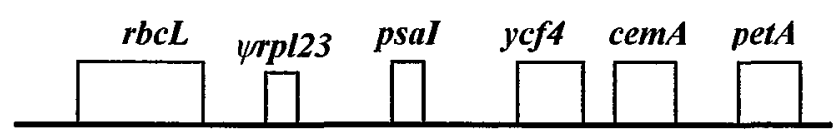

Cana-de-açúcar*

(5.674 pb)

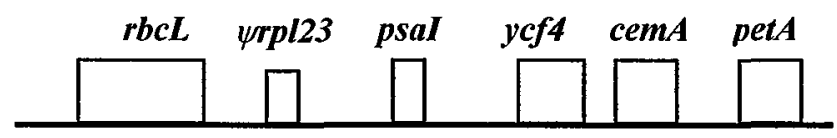

Figura 2 - Variação entre os plastomas de plantas terrestres na região intergênica $r b c L$ petA. Comparando tabaco, arroz, trigo, sorgo, milho e cana, é observada uma tendência para perda do gene $a c c D$, onde o arroz ocupa um lugar intermediário. ${ }^{*} S$. robustum e $S$. spontaneum apresentam, respectivamente, $5.670 \mathrm{pb}$ e $5.672 \mathrm{pb}$ 


\subsection{Análise Comparativa das Sequiências de Nucleotídeos}

Para identificar marcadores filogenéticos ou "hotspots" em sequêencias de nucleotídeos do DNA cloroplastidial de espécies e híbridos de cana-de-açúcar (Saccharum spp.), foram realizadas análises comparativas de regiões alvo de seus plastomas com os de outras espécies de gramíneas, como sorgo, milho, arroz e trigo, buscando analisar as similaridades e diversidades entre eles. As seqüências de nucleotídeos das regiões estudadas [ $16 S r D N A, r p l 22\left(\mathrm{IR}_{\mathrm{B}} / \mathrm{LSC}\right), n d h H\left(\mathrm{IR}_{\mathrm{A}} / \mathrm{SSC}\right), n d h F$ $\left(\mathrm{SSC}_{\mathrm{A}} \mathrm{R}_{\mathrm{B}}\right), p s b A\left(\mathrm{LSC} / \mathrm{IR}_{\mathrm{A}}\right)$, regiões intergênicas entre $r b c L$ e petA e entre $t r n I$ e $\left.t r n L\right]$, obtidas no sequenciamento de 8 variedades de cana e 1 cultivar de sorgo, e através de busca no banco de dados NCBI (2004) dos plastomas do milho, trigo e arroz, foram concatenadas para cada espécie analisada. Então, realizou-se o alinhamento com o programa acessório ClustalW presente no programa BioEdit (2004).

Observou-se que a região $16 S r D N A$ e as regiões que incluem os genes $p s b A$, rpl22 e $n d h H$ são conservadas entre as espécies e híbridos de cana-de-açúcar (100\% de similaridade ao nível de nucleotídeos), existindo alguma divergência na composição de bașes nitrogenadas quando se comparou com as mesmas regiões dos plastomas de sorgo, milho, arroz e trigo (dados não apresentados), também verificado em outras espécies por Maier et al., 1990; Matsuoka et al., 2002 e Odintsova \& Yurina 2003. Por outro lado, a região que inclui o gene $n d h F$ e as duas regiões intergênicas ( $r b c L-p e t A$ e $\operatorname{trnI-trnL)}$ apresentam algumas mutações pontuais de nucleotídeos entre algumas espécies de canade-açúcar e outras espécies como sorgo, milho, arroz e trigo, exibindo mutações do tipo transversão (mutação em que uma purina originou uma pirimidina ou vice-versa), transição (mutação onde uma purina foi substituída por outra purina ou uma pirimidina foi substituída por outra pirimidina) e indel de nucleotídeo (evento que envolveu deleção ou inserção nucleotídica, verificado através da comparação de cadeias nucleotídicas homólogas com comprimentos diferentes), também verificado em outras espécies (Maier et al., 1995; Catalan et al., 1997). Os alinhamentos da região que inclui o gene $n d h F \mathrm{e}$ 
das regiões intergênicas trnI-trnL e rbcL-petA estão nos Anexos B, C e D, respectivamente.

\subsubsection{Comparação das posições das intersecções dos plastomas de espécies Poaceae}

As intersecções entre as duas regiões de repetição invertida $\left(\operatorname{IR}_{A}\right.$ e $\left.\operatorname{IR}_{B}\right)$ e as duas regiões de cópia única (LSC e SSC) freqüentemente diferem entre os plastomas de várias espécies. Expansões e reduções do tamanho do plastoma são geralmente causadas por expansão ou redução das regiões de repetição invertida (Palmer, 1991). Neste sentido, buscou-se verificar a posição dos genes que se encontram nas intersecções ou próximos delas, os quais são: gene rpl22 (proteína ribossomal L22), $n d h H$ (NADHDesidrogenase $\mathrm{H}$ ), $n d h F$ (NADH-Desidrogenase $\mathrm{F}$ ) e $p s b A$ (codifica a proteína D1 do fotossistema II presente no tilacóide). Para isso, contou-se o número de bases nitrogenadas entre a intersecção do DNA cloroplastidial e o códon de iniciação ou terminação do gene presente próximo dela. A comparação da posição dos genes nos plastomas de cana-de-açúcar, milho, sorgo, arroz e trigo encontra-se na Figura 3. 

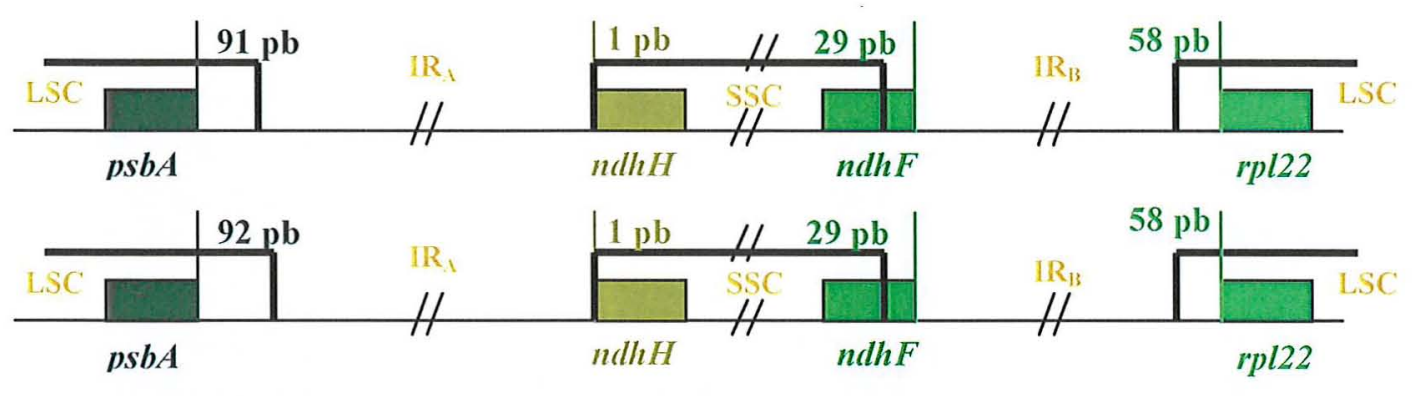

ESPÉCIES DE

CANA

SORGO

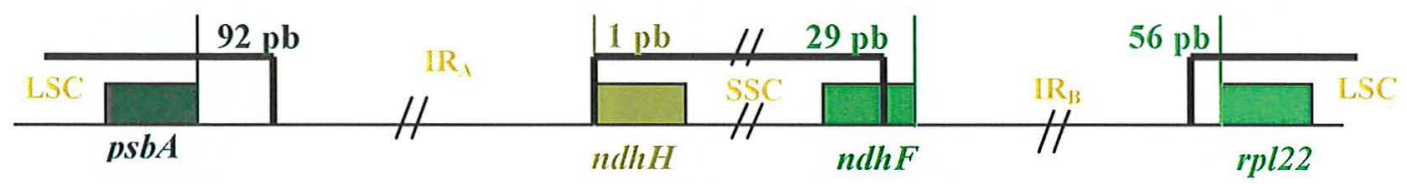

MILHO

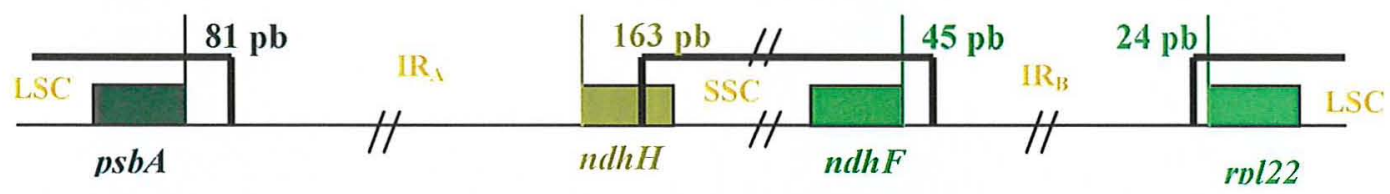

ARROZ

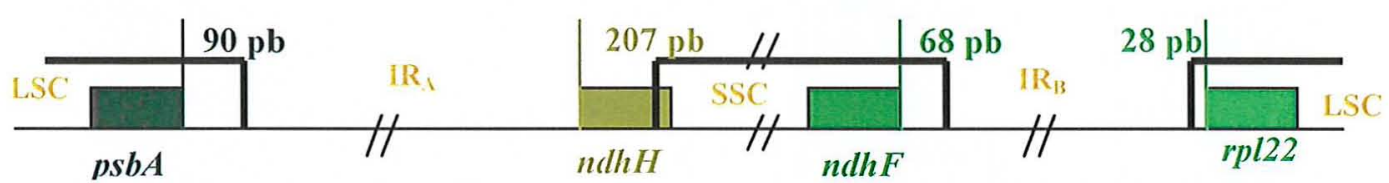

TRIGO

Figura 3 - Comparação das relativas posições das intersecções LSC/IRA, IRA/SSC, $\mathrm{SSC} / \mathrm{IRB}_{\mathrm{B}}, \mathrm{IRB} / \mathrm{LSC}$ e os genes $p s b A, n d h H, n d h F$ e $r p l 22$, respectivamente, entre os plastomas da cana-de-açúcar, sorgo, milho, arroz e trigo

A Figura 3 apresenta o alinhamento das seqüências de nucleotídeos destacando as posições das interseç̧ões dos plastomas das gramíneas, reforçando a estrutura conservada dos plastomas das espécies de cana-de-açúcar, sorgo e milho, os quais apresentam poucas variações.

As intersecções entre as duas repetições invertidas $\left(\mathrm{IR}_{\mathrm{A}} \mathrm{e} I \mathrm{R}_{\mathrm{B}}\right)$ e as duas regiões de cópia única (SSC e LSC) variam muito entre as espécies de plantas, embora as seqüências de nucleotídeos nas regiões IR sejam conservadas (Palmer, 1991; Maier et al., 1995). Uma vez que o conteúdo gênico e o arranjo dos genes nestas regiões dos plastomas estudados sejam correspondentes, as posições das bordas não são idênticas.

Analisando a Figura 3, verifica-se que em todos os plastomas estudados as intersecções entre o IR e LSC foram localizadas dentro da região intergênica entre rps 19 (dentro do IR) e psbA ou rpl22 localizados no LSC, havendo polimorfismo na posição 
das interseções $L S C / I_{A}$ e $I_{B} / L S C$. Em milho e sorgo o códon de terminação do gene psbA está localizado a $92 \mathrm{pb}$ da intersecção $\mathrm{LSC} / \mathrm{IR}_{\mathrm{A}}$, ao passo que nas espécies de cana o códon de terminação deste gene está a 91 pb da intersecção. Em cana-de-açúcar, sorgo e milho o códon de iniciação do gene $n d h H$ é desfeito pela intersecção $I_{\mathbb{A}} / S S C$, e $\mathrm{SSC} / \mathrm{IR}_{\mathrm{B}}$ está localizada dentro da região codificadora do gene $n d h F$. Em arroz e trigo a intersecção $\mathrm{IR}_{\mathrm{A}} / \mathrm{SSC}$ se encontra dentro da região codificadora do gene $n d h H$, ao passo que todo o gene $n d h F$ está inserido na região pequena de cópia única (SSC), próximo da intersecção com a região invertida repetida. O gene rpl22 está inserido na região LSC de todos os plastomas, havendo polimorfismo na posição deste gene em relação à intersecção.

Mudanças nas posições das intersecções entre IR e LSC foram relatadas em várias espécies de angiospermas, demonstrando que esta intersecção não é estática (Kato et al., 2000; Goulding et al., 1996; Perry et al., 2002). Maier et al. (1995) mostraram que todas as posições de intersecções podem variar inclusive entre os plastomas de espécies relacionadas tais como milho e arroz.

Foi sugerido que as características dos plastomas de cana-de-açúcar, sorgo e milho com relação às intersecções entre IR e SSC surgiram devido à recombinação intramolecular (Maier et al., 1995). Estas características estruturais dos plastomas analisados demonstram que o milho, o sorgo e a cana-de-açúcar são mais proximamente relacionados uns aos outros do que com trigo e arroz.

De acordo com Ogihara et al. (2002), algumas alterações estruturais nos genes cloroplastidiais tem sido reconhecidas já entre os plastomas de gramíneas. Estas alterações são o resultado de dois processos: deslizamento na replicação ou recombinação intramolecular mediada por repetições diretas simples, e simples perda de nucleotídeo durante a replicação (Ogihara et al., 1991). Então, a recombinação intramolecular entre as seqüências repetidas poderia ser proposta como uma causa dos diferentes comprimentos entre os plastomas das espécies proximamente relacionadas de cana-de-açúcar e arroz. O deslizamento da DNA-polimerase durante a replicação do plastoma parece ser um mecanismo adicional que causa as mutações em comprimento (Palmer, 1991; Morton \& Clegg, 1993). 


\subsubsection{Análise das regiões divergentes dos plastomas de espécies e híbridos de cana- de-açúcar comparados com outras espécies da família Poaceae}

Destacando partes dos alinhamentos da região que inclui o gene $n d h F$ (Figura 4) e das regiões intergênicas trnI-trnL (Figura 5) e rbcL-petA (Figura 6), observa-se na Figura 4-A (enfoque para os nucleotídeos presentes no quadro) que as espécies $S$. spontaneum, sorgo, milho e trigo exibem substituição de nucleotídeo na mesma posição havendo mutação do tipo transversão [guanina $(G)$ foi substituída por timina $(T)$ ]. Na Figura 4-B (nucleotídeos presentes no quadro), verifica-se que as espécies $S$. robustum, S. barberi Saretha e $S$. spontaneum apresentam substituição de nucleotídeo na mesma posição presente em sorgo, milho, arroz e trigo, havendo mutação do tipo transversão, onde uma pirimidina foi substituída por uma purina. Nesta posição, os híbridos SP803280, H72-1522, CP72-1210 e POJ2878 e a espécie $S$. officinarum (Badila) apresentam a mesma base citosina $(\mathrm{C})$ ao invés de adenina $(\mathrm{A})$ presente nas outras espécies de canade-açúcar.

Na Figura 5-A, verifica-se que o híbrido H72-1522 e a espécie $S$. barberi Saretha apresentam a mesma substituição de três bases nitrogenadas (presentes no quadro), diferindo das outras espécies. Também se observa deleção de bases nitrogenadas nas espécies $S$. spontaneum, sorgo e milho entre as posições dos nucleotídeos 1.002 e 1.007 (presentes no quadro), o que não ocorre nas outras espécies de cana (Figura 5-B).

$\mathrm{Na}$ Figura 6-A, nota-se a substituição de bases do tipo transição (enfoque para os nucleotídeos presentes no quadro), sendo que a espécie $S$. officinarum (Badila) e os híbridos SP80-3280, H72-1522, CP72-1210 e POJ2878 apresentam a mesma base guanina (G) ao invés de adenina (A). Já na Figura 6-B, verifica-se a existência de uma maior deleção de bases nitrogenadas na espécie $S$. robustum (Molokai 5099) (enfoque no quadro). O trigo não apresenta deleção nesta posição entre os nucleotídeos $3.322 \mathrm{e}$ 3.328 , referente à espécie $S$. robustum. Substituições únicas de nucleotídeos não são marcadores filogenéticos perfeitos (Rokas \& Holland, 2000). Os alinhamentos das seqüências completas que incluem o gene $n d h F$ e as regiões intergênicas (trnI-trnL e $r b c L$-petA) se encontram nos Anexos B, C e D, respectivamente. 
S. officinarum (SP80-3280)

Híbrido POJ 2878

Hibrido H72-1522

Híbrido CP72-1210

S. officinarum (Badila)

S. robustum (Molokai 5099)

S. barberi Saretha (Chunnee)

S. spontaneum (Krakatau)

Sorghum bicolor (cv 822)

Zea mays

Oryza sativa

Triticum aestivum

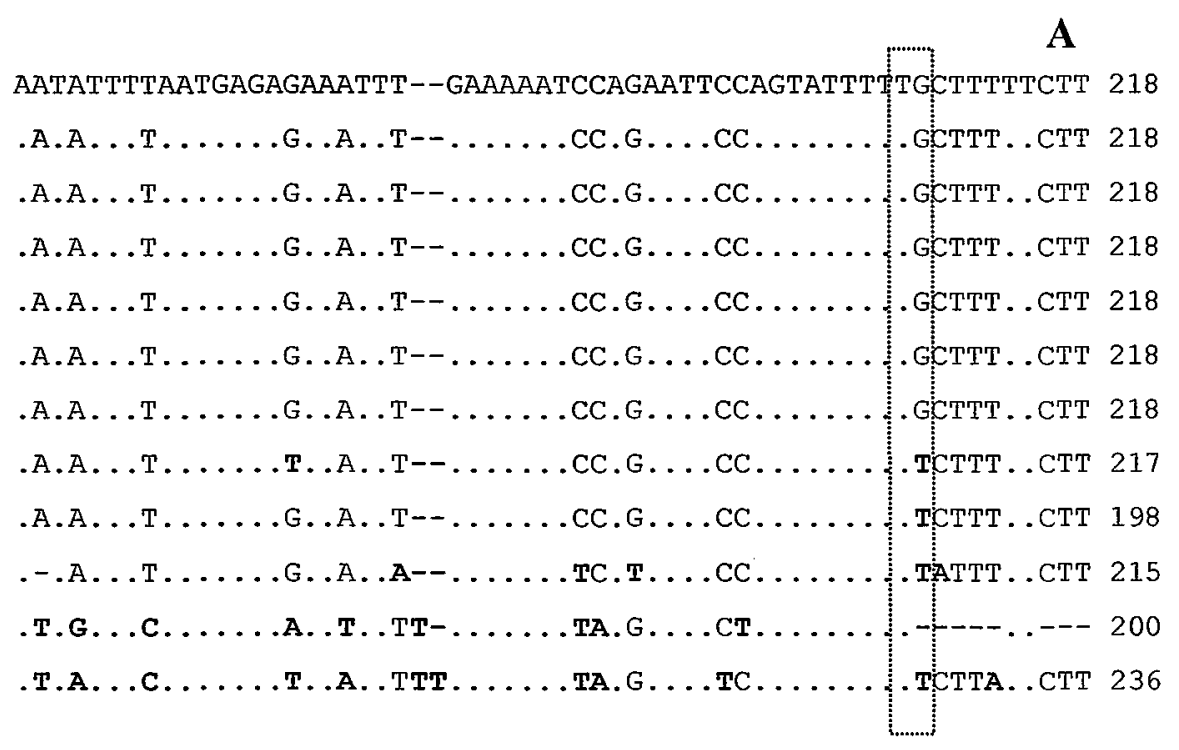

B

S. officinarum (SP80-3280)

Híbrido POJ 2878

Híbrido H72-1522

Híbrido CP72-1210

S. officinarum (Badila)

S. robustum (Molokai 5099)

S. barberi Saretha (Chunnee)

S. spontaneum (Krakatau)

Sorghum bicolor (cv 822)

Zea mays

Oryza sativa

Triticum aestivum .A.A...T..........T-_......C.G....CC......GСTTT..CTT 218

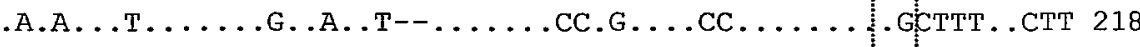

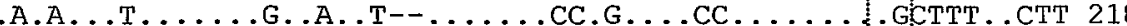
.A.A... ..........T-_.....CC.G...CC.......GTTT..CTT 218

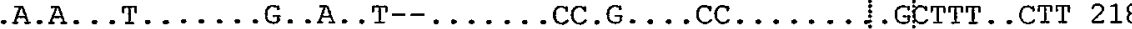

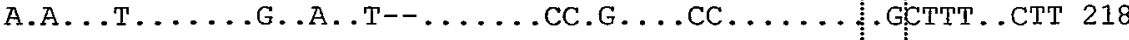

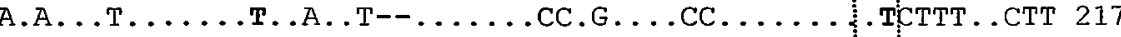

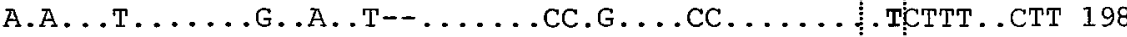

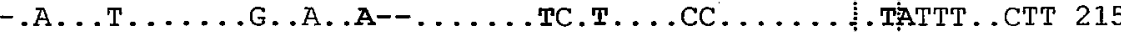
T.A. . C..........T.T. TA.G. . . TC

\section{0}

AATATTTTAATGAGAGAAATTT--GAAAAATCCAGAATTCCAGTATTTTiTGCTTTTTCTT 218

\section{B}

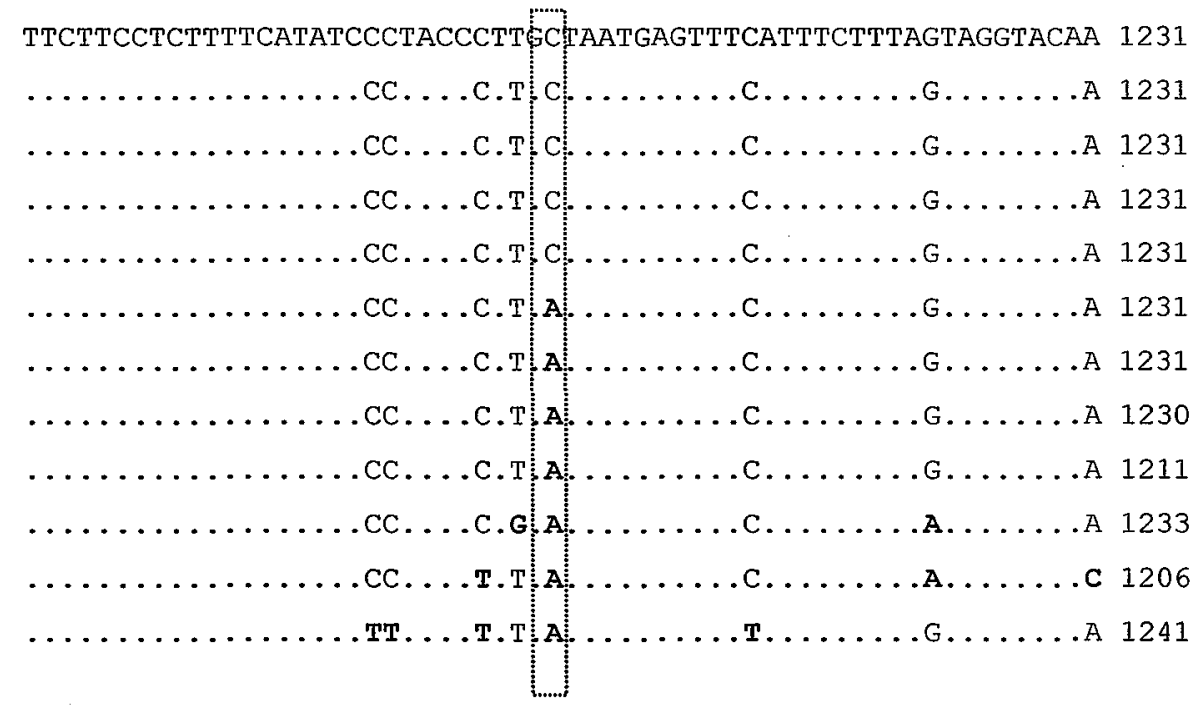

Figura 4 - Destaque de parte do alinhamento da região que inclui o gene $n d h F$ representados por A e B. Os pontos alinhados representam as mesmas bases nitrogenadas do híbrido SP80-3280. Os traços representam os gaps (deleções de bases nitrogenadas). As mutações são apresentadas pelas bases nitrogenadas em negrito que diferem do híbrido SP80-3280 
S. officinarum (SP80-3280)

Hibrido POJ 2878

Híbrido H72-1522

Híbrido CP72-1210

S. officinarum (Badila)

S. robustum (Molokai 5099)

S. barberi Saretha (Chunnee)

S. spontaneum (Krakatau)

Sorghum bicolor (cv 822)

Zea mays

Oryza sativa

Triticum aestivum

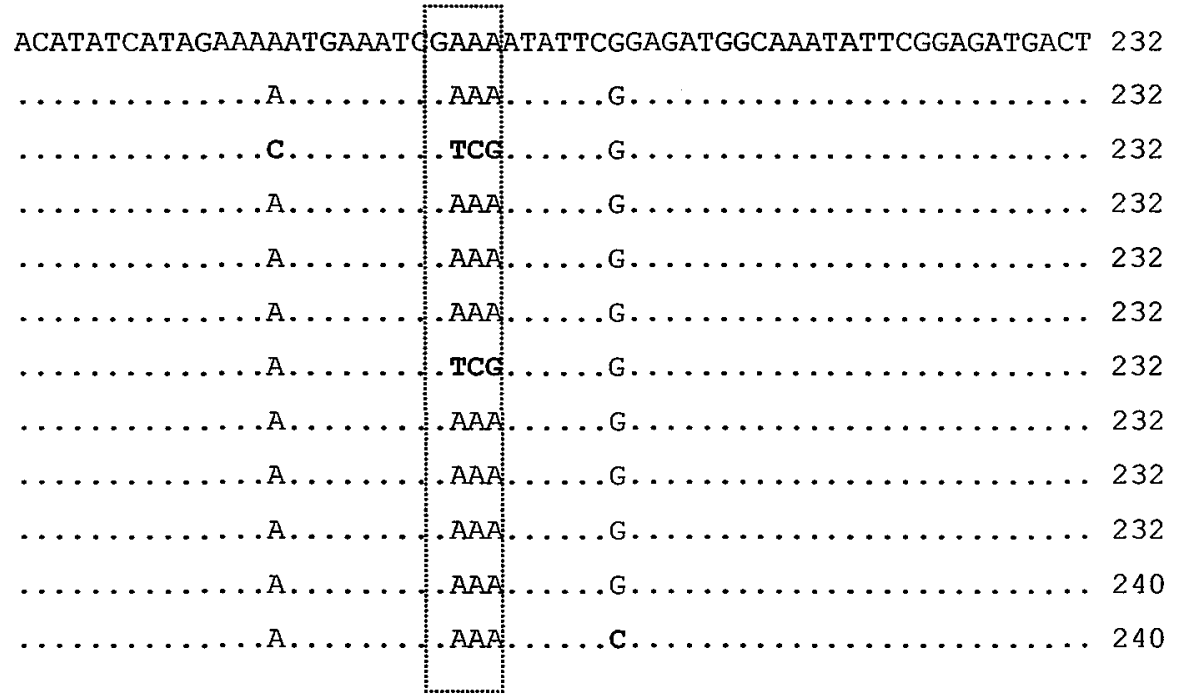

B

S. officinarum (SP80-3280)

Híbrido POJ 2878

Hibrido H72-1522

Hibrido CP72-1210

S. officinarum (Badila)

S. robustum (Molokai 5099)

S. barberi Saretha (Chunnee)

S. spontaneum (Krakatau)

Sorghum bicolor (cv 822)

Zea mays

Oryza sativa

Triticum aestivum

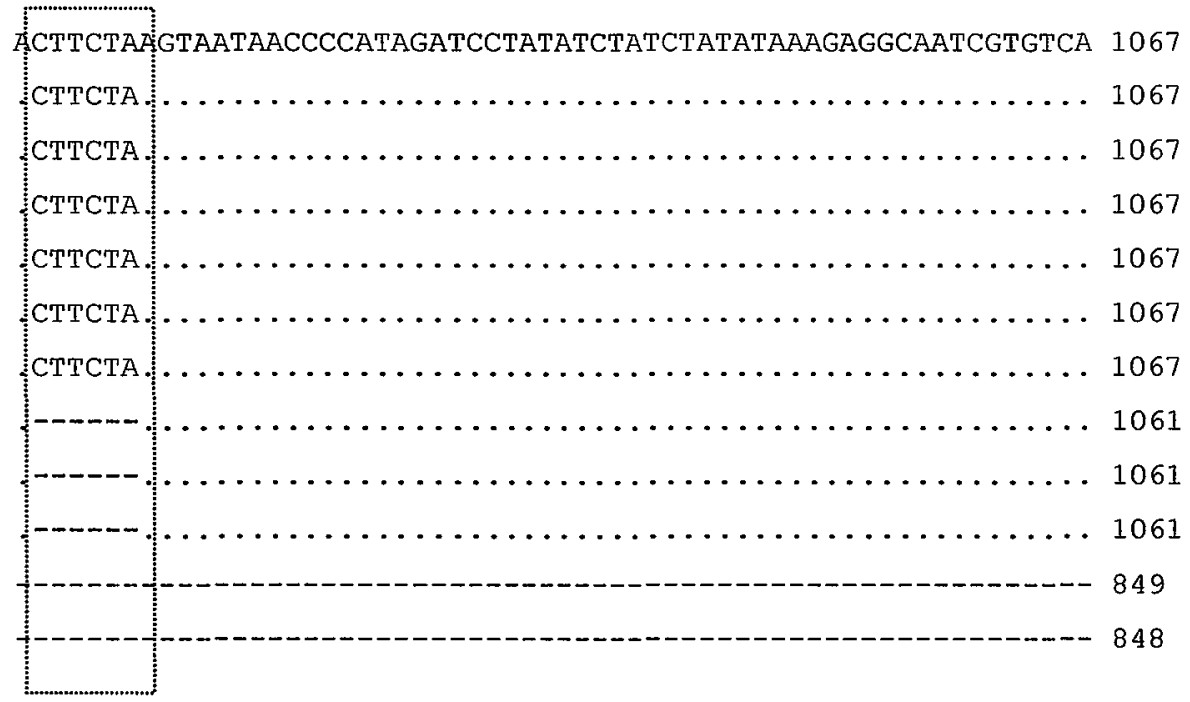

Figura 5 - Destaque de parte do alinhamento da região intergênica trnI-trnL representados por A e B. Os pontos alinhados representam as mesmas bases nitrogenadas do híbrido SP80-3280. Os traços representam os gaps (deleções de bases nitrogenadas). As mutações são apresentadas pelas bases nitrogenadas em negrito que diferem do híbrido SP80-3280 
S. officinarum (SP80-3280)

Híbrido POJ 2878

Híbrido H72-1522

Híbrido CP72-1210

S. officinarum (Badila)

S. robustum (Molokai 5099)

S. barberi Saretha (Chunnee)

S. spontaneum (Krakatau)

Sorghum bicolor (cv 822)

Zea mays

Oryza sativa

Triticum aestivum

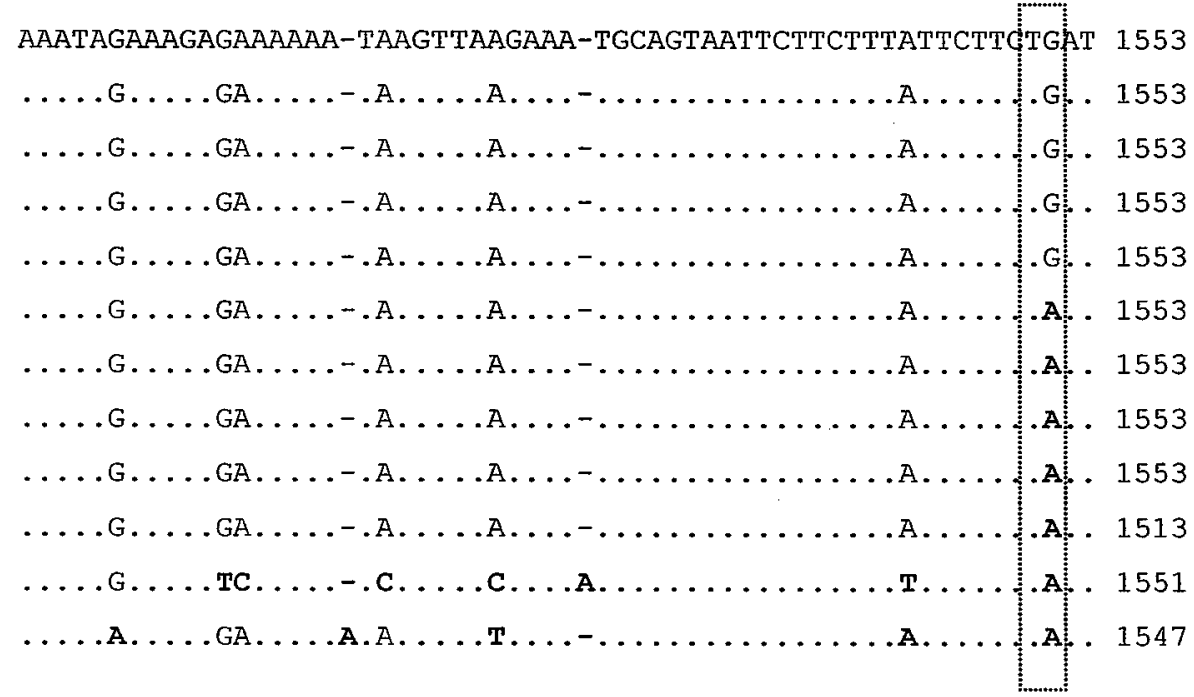

B

S. officinarum (SP80-3280)

Híbrido POJ 2878

Híbrido H72-1522

Híbrido CP72-1210

S. officinarum (Badila)

S. robustum (Molokai 5099)

S. barberi Saretha (Chunnee)

S. spontaneum (Krakatau)

Sorghum bicolor (cv 822)

Zea mays

Oryza sativa

Triticum aestivum

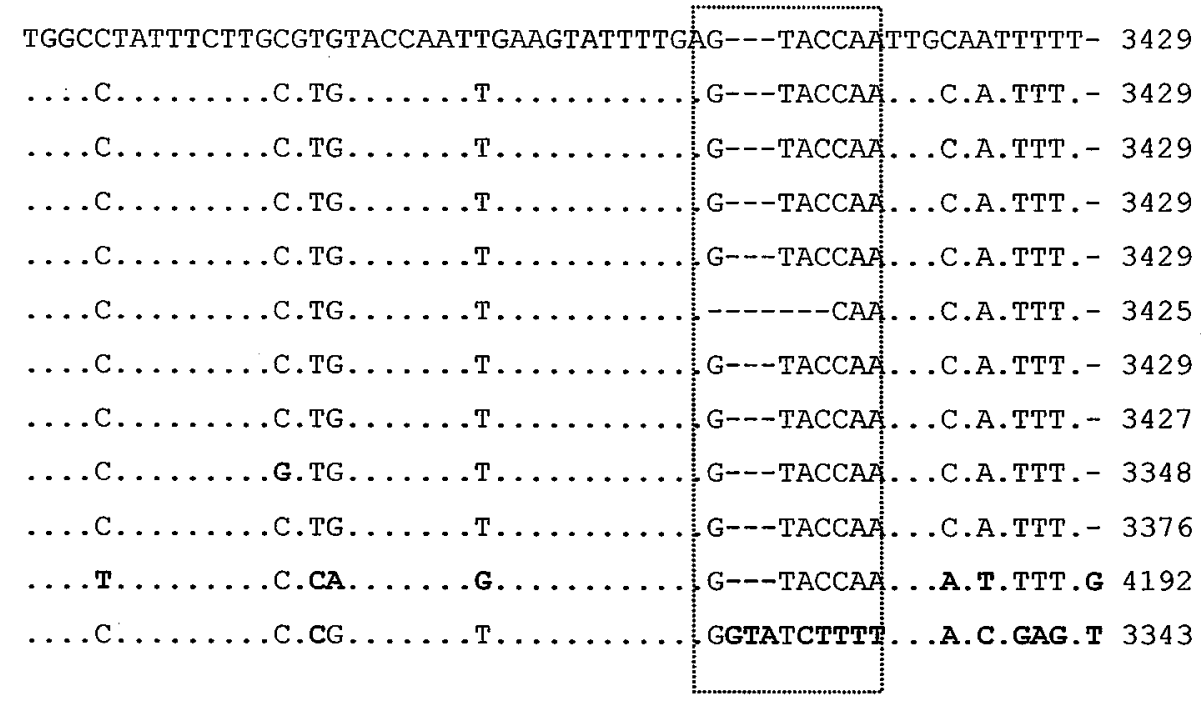

Figura 6 - Destaque de parte do alinhamento da região intergênica $r b c L$-petA representados por A e B. Os pontos alinhados representam as mesmas bases nitrogenadas do híbrido SP80-3280. Os traços representam os gaps (deleções de bases nitrogenadas). As mutações são apresentadas pelas bases nitrogenadas em negrito que diferem do híbrido SP80-3280 
Ao observar os alinhamentos da região que inclui o gene $n d h F$ e das regiões intergênicas trnI-trnL e rbcL-petA dos híbridos e espécies de cana-de-açúcar, incluindo outras gramíneas como sorgo, milho, arroz e trigo (Anexos B, C e D), foi possível verificar vários aspectos evolutivos entre as espécies estudadas. Os membros da família Poaceae foram especialmente estudados quanto à divergência de seus plastomas e mutações no comprimento, sendo identificadas através da comparação de seqüências de nucleotídeos (Ogihara et al., 1988; Maier et al, 1995).

Geralmente é difícil inferir as relações filogenéticas entre espécies proximamente relacionadas devido à falta de marcadores filogenéticos exibindo suficiente variabilidade nucleotídica neste nível taxonômico. Comparando as espécies e híbridos de cana-deaçúcar analisados quanto às regiões selecionadas do plastoma, observou-se um alto grau de similaridade, exibindo baixo sinal filogenético no nível intraespecífico. Os genomas plastidiais de plantas superiores são geralmente conservados no comprimento, estrutura, e complemento gênico (Clegg et al., 1991). Ao nível de sequiência de DNA, os genes plastidiais apresentam uma reduzida taxa de substituição de nucleotídeos, comparado com os genes nucleares (Wolfe et al., 1987; Clegg et al., 1991). As regiões intergênicas trnI-trnL e rbcL-petA e a região que inclui o gene $n d h F$ apresentaram divergências quanto a composição nucleotídica quando se comparou todas as espécies estudadas.

Em geral, verificou-se a existência de maior identidade entre as regiões alvo dos plastomas de cana-de-açúcar, sorgo e milho. Isto indica que tanto as regiões codificadoras como intergênicas são muito similares entre estas espécies. Segundo Calsa Jr (2001) existe similaridade estrutural significativamente elevada entre os plastomas de milho e cana-de-açúcar.

Comparações das seqüências completas dos plastomas de trigo e milho revelaram alteração estrutural nestes plastomas de gramíneas na região IR entre trnIle (CAC) e trnLeu (CAA) (Ogihara et al., 2002). Os plastomas de gramíneas são altamente conservados, mas alguns "hotspots" para mutação estrutural no plastoma foram observados (Ogihara et al., 2002). 
A similaridade entre as espécies de cana-de-açúcar, sorgo e milho pôde ser verificada na região intergênica entre trnI e trnL, havendo poucas mutações de nucleotídeos que foram utilizadas nas análises filogenéticas.

Um "hotspot" para mutações em comprimento foi encontrado no gene $y c f 2$, o qual se encontra entre os genes trnI e $\operatorname{trn} L$, apresentando-se conservado nas dicotiledôneas (Shinozaki et al., 1986; Hupfer et al., 2000; Schmitz-Linneweber et al., 2001; Ogihara et al., 2002) como tabaco (Maier et al., 1995). Quando as sequêencias de nucleotídeo da região $y c f 2$ de tabaco e das plantas gramíneas foram alinhadas (Figura 1), pelo menos duas deleções foram notadas: uma deleção ocorreu dentro de $y c f 2$, então duas ORFs foram geradas (ORF 46 e ORF 34). Também, o segmento de DNA incluindo a ORF 92 foi deletada dos plastomas das gramíneas, e subseqüentemente uma nova ORF foi produzida (ORF 173 para cana-de-açúcar, sorgo e milho e ORF 249 para arroz e trigo). Após as substituições e/ou rearranjos menores das seqüências, várias ORFs menores foram geradas nos plastomas de cana-de-açúcar, sorgo e milho na posição da ORF maior (ycf2). As ORFs remanescentes (ORF 46, ORF 34, ORF 241, ORF 139 e ORF 38 na cana-de-açúcar, sorgo e milho) apresentam homologia com seus homólogos em tabaco. Quando uma comparação de seqüências de nucleotídeos da região $y c f 2$ dos plastomas de gramíneas foi conduzida, a região contendo a ORF 139, a ORF 38 e o gene $y c f 15$, foi encontrada por ter sido eliminada dos plastomas de trigo e arroz (Figura 1). Desde que a região remanescente contendo as ORFs (ORF 28 e ORF 64) em trigo e arroz apresentaram alta similaridade com a ORF241 da cana-de-açúcar, sorgo e milho, é plausível assumir que o rearranjo foi um simples evento de deleção. As porções deletadas dos plastomas de trigo e arroz eram quase idênticas, sugerindo que tais plastomas dividem um progenitor comum após a deleção envolvendo esta região. Ainda não é conhecido se estas ORFs são funcionais nos plastomas das gramíneas.

$\mathrm{Na}$ Figura 1, observa-se que o gene $y c f 2$, conservado no plastoma de dicotiledôneas como tabaco (Maier et al., 1995), é um "hotspot" para mutações em comprimento nas monocotiledôneas (Ogihara et al., 2002), desde que sofreu um processo truncado durante a evolução das Poaceae (Katayama \& Ogihara, 1996). Muitas ORFs resultaram deste processo, e a divergência estrutural desta região entre as 
gramíneas sugeriu que cana-de-açúcar, sorgo e milho ainda mantêm fragmentos maiores de $y c f 2$ do que arroz e trigo, que perderam completamente este gene (Figura 1, Maier et al., 1995). A cana-de-açúcar apresenta a região que contém o gene ycfl5 (também denominada de ORF99), presente no milho e sorgo enquanto está ausente em arroz e trigo (Maier et al., 1995). Supõe-se que o produto do $y c f 2$ apresenta papel essencial no metabolismo das células de plantas dicotiledôneas (Drescher et al., 2000), entretanto investigações adicionais poderiam ser realizadas para saber se $y c f 15$ é funcionalmente importante nos plastídios, e em que extensão, os genes $y c f 2$ e $y c f 15$ são substituídos por produtos de genes codificados pelo genoma nuclear nas espécies onde estão ausentes. Também, a região do gene ycfl5 que está presente em cana-de-açúcar, milho e sorgo e ausente em trigo e arroz (Maier et al., 1995) é um importante "hotspot" destas espécies.

Um outro "hotspot" para mutação em comprimento está localizado na região de cópia única grande entre os genes $r b c L$ e petA (Figura 2). Uma comparação das seqüências de nucleotídeos com a região correspondente das dicotiledôneas (Shinozaki et al., 1986; Hupfer et al., 2000; Schmitz-Linneweber et al., 2001) revelou dois rearranjos nos plastomas de cana-de-açúcar, milho, sorgo e trigo, havendo deleção do gene $a c c D$ (forma procariótica de acetil-CoA-carboxilase) e translocação não-recíproca do rpl23 (Ogihara et al., 1988). Entretanto, um remanescente do gene $a c c D$ foi encontrado no arroz (ORF106) (Hiratsuka et al., 1989), sendo que a deleção deste gene parece ter ocorrido várias vezes durante o curso de evolução das espécies da família Poaceae. Embora proximamente relacionado ao arroz, o plastoma de trigo parece ter seguido a mesma rota evolutiva do sorgo, milho e cana-de-açúcar considerando este "hotspot" de divergência.

Na região montante (downstream) do gene $r b c L$, um "hotspot" para mutações em comprimento foi relatada no complexo do trigo (Ogihara et al., 1991) e na família das gramíneas (Morton \& Clegg, 1993).

A translocação não-recíproca do pseudogene $\psi r p l 23$ ocorreu recentemente durante o curso de diferenciação da família Poaceae de seu ancestral direto, Joinvelleaceae (Katayama \& Ogihara, 1996). Após a translocação não-recíproca do 
pseudogene $\psi r p l 23$, deleções envolvendo porções homólogas do gene $a c c D$ ocorreu repetidamente durante a diferenciação das linhagens de trigo e milho.

O pseudogene $\psi r p l 23$, localizado entre $r b c L$ e ORF106 no plastoma de arroz, é mantido na posição homóloga dos plastomas de cana-de-açúcar, milho, sorgo e trigo numa forma menos degradada, em que a redução no tamanho causado pela perda da ORF106 é compensada por alguma extensão (Figura 2). Este pseudogene, presente na região divergente do plastoma das espécies analisadas, não é indicativo de uma transferência gênica para o genoma nuclear ou a perda completa do gene codificado pelo plastoma, pois as cópias funcionais do gene rpl23 ainda existem nas regiões repetidas invertidas (Maier et al., 1995). Outra deleção envolvendo uma parte do gene rpl23 translocada ocorreu no plastoma de arroz. Além disso, um número de recombinações ilegítimas ocorreu ao redor da parte translocada do gene rpl23 nas espécies de trigo, tornando esta região altamente variável com respeito às mutações no comprimento (Ogihara et al., 1991). Em contraste, pouca divergência na seqüência ocorreu em milho, não havendo variações na região correspondente (Doebley et al., 1987; Morton \& Clegg, 1993).

A região intergênica entre $r b c L$ e petA, descrita como divergente entre os plastomas já seqüenciados de espécies vegetais superiores (Maier et al., 1995), mostrouse praticamente idêntica entre as espécies e híbridos de cana-de-açúcar, o cultivar de sorgo e o milho. Dados moleculares do gene $r b c L$ foram usados com sucesso para resolver a relação filogenética na família ou níveis taxonômicos superiores (Chase et al., 1993; Zurawski et al., 1984). Em combinação com outras sequiências, o gene $r b c L$ foi útil em níveis taxonômicos inferiores (Muasya et al., 2001, 2002).

Metodologias alternativas para análises filogenéticas de genomas completamente seqüenciados foram propostas, por exemplo, baseando-se no rearranjo da ordem dos genes (Sankoff et al., 1992), a presença e ausência de famílias gênicas que codificam proteínas (Fitz-Gibbon \& House, 1999), conteúdo gênico e a total similaridade (Tekaia et al., 1999), e a ocorrência de duplicações e ortólogos (Lin \& Gerstein, 2000).

Alguns trabalhos apresentam análises de evolução de espécies gramíneas comparando seqüências de nucleotídeos do gene que expressa a enzima 
fosfoenolpiruvato carboxilase (PEPC; EC4.1.1.3) (gene nuclear) (Bläsing et al., 2002; Svensson et al., 2003), sugerindo relações filogenéticas com base na distinção de plantas que apresentam fotossíntese do tipo $\mathrm{C}_{3}$ e tipo $\mathrm{C}_{4}$.

$\mathrm{O}$ ciclo de Calvin (ciclo de fixação do carbono) também é conhecido como a rota $\mathrm{C}_{3}$ de fixação do carbono, uma vez que o produto formado é um composto de três carbonos (ácido fosfoglicérico). Este ciclo, presente em gramíneas como arroz e trigo, pode ser dividido em quatro fases distintas: fase de carboxilação, fase de redução, fase de regeneração e fase de síntese dos produtos. A fase de carboxilação consiste na reação do $\mathrm{CO}_{2}$ com a ribulose bisfosfato, catalisada pela enzima ribulose-1,5-bisfosfato carboxilase (Rubisco), seguida por uma clivagem molecular, formando o ácido fosfoglicérico (produto composto por três carbonos). A fase de redução consiste na redução do ácido glicérico, formado na etapa anterior, em trioses fosfato. A fase de regeneração consiste na regeneração da ribulose bisfosfato através de reações de interconversão de açúcares. A fase de síntese de produtos consiste na produção de outros compostos, tais como, polissacarídeos, aminoácidos e ácidos graxos. A síntese desses compostos é influenciada pelas condições físiológicas. Entretanto, esta não é a única rota de fixação do $\mathrm{CO}_{2}$. Na maioria das plantas e gramíneas tropicais, tais como cana-deaçúcar, milho e sorgo, a fixação do $\mathrm{CO}_{2}$ resulta em compostos de quatro carbonos como o oxaloacetato, o malato ou o aspartato. A fixação ocorre pela carboxilação do fosfoenolpiruvato a oxaloacetato, malato ou aspartato a ser catalisado pela enzima fosfoenolpiruvato carboxilase (PEPC). Por essa razão, essa rota é chamada de $\mathrm{C}_{4}$. Este $\mathrm{CO}_{2}$ é posteriormente liberado pela descarboxilação do oxaloacetato, malato ou aspartato e refixado no ciclo de Calvin pela Rubisco. Nos vegetais que apresentam metabolismo $\mathrm{C}_{4}$, a fixação do $\mathrm{CO}_{2}$ ocorre nas células fotossintéticas presentes no mesofilo da folha. $\mathrm{O}$ carbono fixado na forma de malato migra para os cloroplastos das células da bainha do feixe vascular onde ocorre então a liberação e refixação do $\mathrm{CO}_{2}$ através do ciclo de Calvin, praticamente eliminando a fotorrespiração nestas plantas (Hatch, 1976; Edwards \& Huber, 1981).

A enzima PEPC faz a reposição dos intermediários do ciclo do ácido cítrico, necessário devido à remoção de metabólitos para a síntese de aminoácidos, heme e 
clorofila. Além disso, a PEPC está envolvida na regulação das funções estomatais, assimilação de nitrogênio, manutenção do $\mathrm{pH}$ e re-fixação de $\mathrm{CO}_{2}$ (Latzko \& Kelly, 1983).

O milho, o sorgo e a cana-de-açúcar são as espécies mais estudadas com respeito a PEPC e contêm pelo menos três diferentes genes PEPCs. A fotossíntese do tipo $\mathrm{C}_{4}$ é um mecanismo de concentração de $\mathrm{CO}_{2}$ envolvendo muitas enzimas específicas e uma anatomia foliar alterada tem desenvolvido muitas vezes e independentemente durante a evolução das angiospermas (Kellogg, 1999). Para entender a evolução das PEPCs em espécies $\mathrm{C}_{4}$ é importante identificar e investigar as outras isoenzimas das quais elas tem desenvolvido.

De acordo com Svensson et al. (2003), as plantas $C_{4}$ apresentam origem polifilética e evoluíram independentemente e diversas vezes durante a evolução das angiospermas. Isso implica que a isoforma da enzima fosfoenolpiruvato carboxilase (PEPC) originou-se de um gene PEPC não fotossintético que já estava presente nas espécies ancestrais $\mathrm{C}_{3}$. Para encontrar os requerimentos necessários para o caminho fotossintético $\mathrm{C}_{4}$, o programa de expressão do gene PEPC de plantas $\mathrm{C}_{4}$ foi mudado para se conseguir uma expressão forte e estável nas células do mesofilo foliar. Em adição, a alterada concentração de metabólitos em torno da PEPC de plantas $\mathrm{C}_{4}$ no citoplasma do mesofilo necessitou de mudanças na cinética enzimática e nas propriedades metabólicas.

A relação filogenética das PEPCs envolvidas na fotossíntese $\mathrm{C}_{4}$ agrupou Sorghum bicolor e Saccharum officinarum num único ramo, indicando que tais espécies apresentam um ancestral comum. A espécie Zea mays é grupo irmão de sorgo e cana-deaçúcar no que se refere à filogenia das PEPCs (Bläsing et al., 2002).

No presente trabalho, verificou-se que a região que inclui o gene $n d h F$ apresenta consideráveis taxas de substituição de nucleotídeos entre as gramíneas $C_{3}$ e $C_{4}$, sugerindo uma evolução comum entre plastomas de gramíneas $\mathrm{C}_{4}$, gerando novos elementos para estudar este tipo de fotossíntese e metabolismo.

Embora algumas divergências tenham sido encontradas até entre cana-de-açúcar, sorgo e milho (gramíneas $\mathrm{C}_{4}$ ), a similaridade estrutural entre seus plastomas é significativa. $\mathrm{O}$ DNA plastidial de arroz e trigo (gramíneas $\mathrm{C}_{3}$ ) não dividem este alto 
nível de similaridade. Sugere-se uma relação filogenética próxima entre os plastomas das espécies de cana-de-açúcar estudadas e as plantas gramíneas de milho e sorgo. Por outro lado existe diversidade filogenética quando se compara com os plastomas de arroz e trigo.

\subsubsection{Análise filogenética das espécies Poaceae estudadas}

Para posicionar filogeneticamente as espécies e híbridos de cana-de-açúcar com relação a outras espécies gramíneas de sorgo, milho, arroz e trigo, foram utilizadas as seqüências de nucleotídeos do cloroplasto selecionadas que foram concatenadas para cada espécie e salvas em formato FASTA. Então, realizou-se o alinhamento de tais seqüências concatenadas utilizando o programa BioEdit Sequence Alignment Editor (2004).

A matriz obtida foi exportada como arquivo NEXUS para então ser executado no programa PAUP*4.0b10 (2004). Os GAPS foram codificados como dados faltantes. A matriz resultante foi analisada utilizando a opção de pesquisa heurística do programa PAUP. A matriz alinhada das regiões do ptDNA concatenadas apresentou: $19.001 \mathrm{pb}$; 17.438 caracteres constantes; 1.563 caracteres variáveis; 1.119 caracteres não informativos para parcimônia; 444 caracteres potencialmente informativos para parcimônia. A Figura 7 apresenta o consenso de 7 árvores filogenéticas geradas.

O trigo (Triticum aestivum) foi selecionado como grupo externo para todas as análises, pois é a espécie evolutivamente mais antiga. Robert J. Braidwood (1948) descobriu sementes de trigo que datam de 6.700 anos A. C. Bem antes de qualquer evidência histórica, o arroz foi, provavelmente, o principal alimento e a primeira planta cultivada na Ásia. As mais antigas referências ao arroz são encontradas na literatura chinesa, há cerca de 5.000 anos (EMBRAPA Arroz e Feijão, 2004). O milho é uma das culturas mais antigas do mundo, havendo provas, através de escavações arqueológicas e geológicas, e através de medições por desintegração radioativa, de que é cultivado há pelo menos 5.000 anos A. C. (EMBRAPA Milho e Sorgo, 2004). A domesticação do 
sorgo, segundo registros arqueológicos, deve ter acontecido por volta de 3.000 anos A. C., ao tempo em que a prática da domesticação e cultivo de outros cereais era introduzida no Egito Antigo a partir da Etiópia (EMBRAPA Milho e Sorgo, 2004). Desconhecida no Ocidente, a cana-de-açúcar foi observada por alguns generais de Alexandre, o Grande, em 327 anos A. C. e mais tarde, no século XI, durante as Cruzadas (TONÉIS E CIA, 2004).

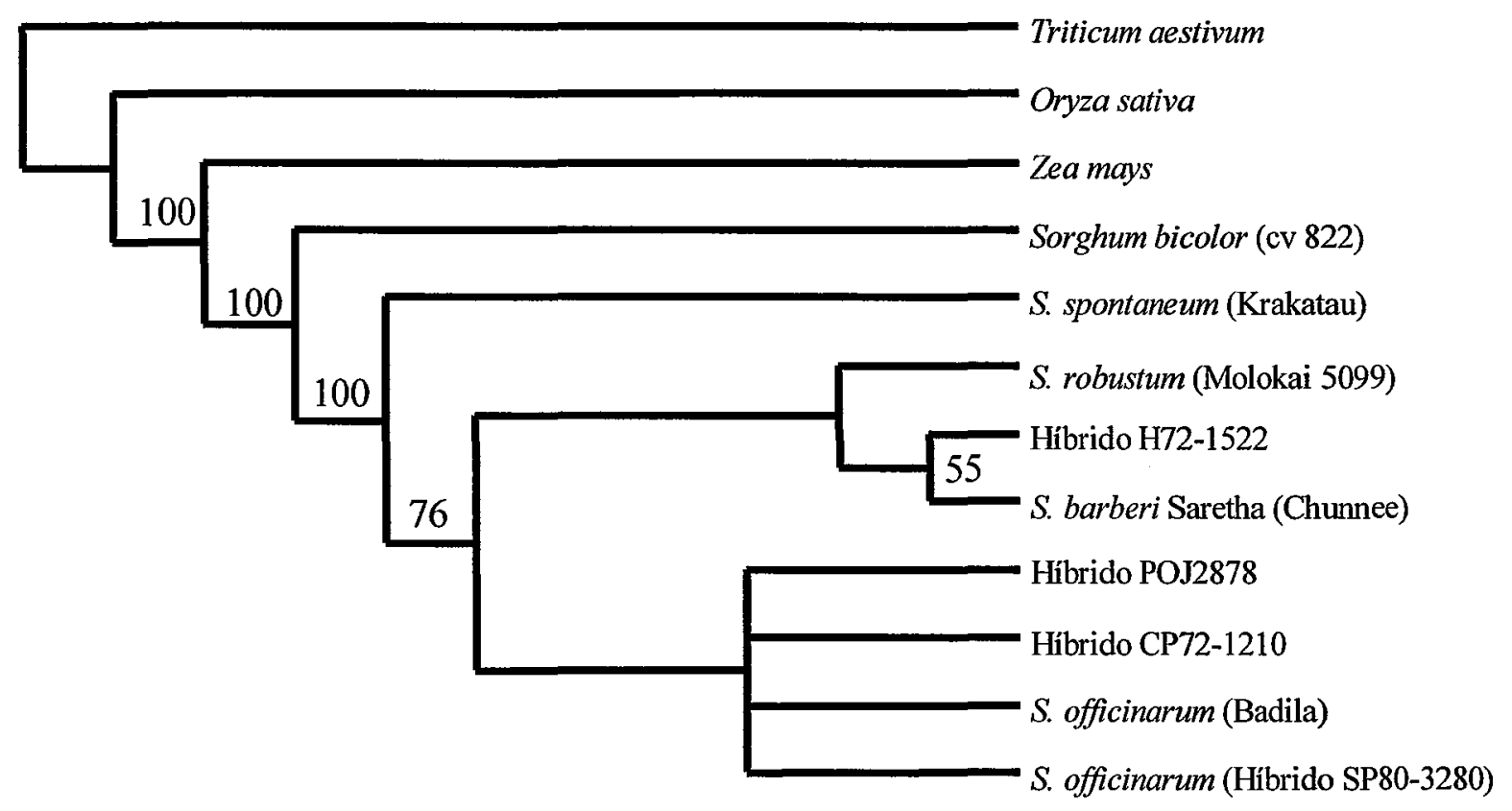

Figura 7 - Relação filogenética entre espécies e híbridos de cana-de-açúcar e outras espécies gramíneas como trigo, arroz, milho e sorgo. Esta é uma árvore de parcimônia considerando todas as regiões do ptDNA selecionadas. Os números são valores de Bootstrap com porcentagens acima de 50\%

A reunião de todas as regiões alvo estudadas produziu a árvore filogenética presente na Figura 7. Tal figura engloba todos os caracteres potencialmente informativos para parcimônia. Analisando esta árvore, verifica-se que o híbrido H72-1522 e a espécie $S$. barberi Saretha (Chunnee) apresentam um ancestral comum, ao passo que os híbridos POJ 2878, CP72-1210 e SP80-3280 e a variedade Badila formam uma politomia, 
existindo um ancestral comum a eles. Entretanto, não é possível reconstruir a hipótese filogenética das espécies e híbridos de cana-de-açúcar selecionados se baseando apenas nas regiões alvo do ptDNA estudadas neste trabalho, pois a árvore obtida pela análise individual de espécies e híbridos de cana-de-açúcar resultou na mesma topologia da árvore apresentada na Figura 7 (dado não mostrado), sendo que o valor mais alto de bootstrap foi $76 \%$, o que demonstra que a matriz não contém divergência suficiente $\mathrm{e}$ dados robustos para estabelecer relações filogenéticas seguras entre as variedades estudadas

Em seguida foram realizadas análises filogenéticas de cada região alvo das espécies estudadas neste trabalho. As regiões que incluem os genes $16 \mathrm{~S} r D N A$, $n d h H$, $p s b A$ e $r p l 22$ apresentam poucas ou nenhuma mutação e foram removidas das análises.

A região que inclui o gene $n d h F$ e as duas regiões intergênicas (rbcL-petA e trnI$\operatorname{trn} L$ ) apresentam algumas mutações pontuais de nucleotídeo entre algumas espécies de cana-de-açúcar e também entre as gramíneas selecionadas para realizar a análise filogenética, existindo mutações do tipo transversões, transições e indel de nucleotídeo (evento que envolveu deleção ou inserção nucleotídica, verificado através da comparação de cadeias nucleotídicas homólogas com comprimentos diferentes). Isto já foi observado em análises do ptDNA que contribuíram para o conhecimento da evolução das gramíneas se baseando na variação da seqüência de nucleotídeos em um único gene como $r b c L$ (Doebley et al., 1990; Soltis et al., 1999; Soltis \& Soltis, 2000) e $n d h F$ (Clark et al., 1995). Maier et al. (1995) e Ogihara et al. (2002) já verificaram a presença de regiões localizadas de divergência como a região entre os genes $\operatorname{trnI}$ e $\operatorname{trn} L$ e a região intergênica entre $r b c L$ e petA, quando realizou análises comparativas entre os plastomas de espécies como tabaco, milho, arroz e trigo. Em contraste aos amplos estudos realizados com enfoque baseado em um único gene, apenas poucos estudos enfocaram a evolução das gramíneas se baseando em múltiplas seqüências de genes cloroplastidiais (Wolfe et al., 1987; Wolfe et al., 1989; Gaut et al., 1993).

Então, optou-se por realizar análises filogenéticas de cada região que apresenta divergência entre as espécies e híbridos de cana-de-açúcar. A Figura 8 apresenta o consenso de apenas uma árvore filogenética gerada pela matriz do alinhamento da região 
do ptDNA que inclui o gene $n d h F$. O método utilizado também foi o da máxima parcimônia e o resultado da pesquisa heurística foi: $3.078 \mathrm{pb}$ de caracteres totais; 2.571 caracteres constantes; 507 caracteres variáveis; 402 caracteres não informativos para parcimônia; 105 caracteres potencialmente informativos para parcimônia. Também o trigo foi selecionado como grupo externo para as análises, pelo mesmo motivo descrito anteriormente.

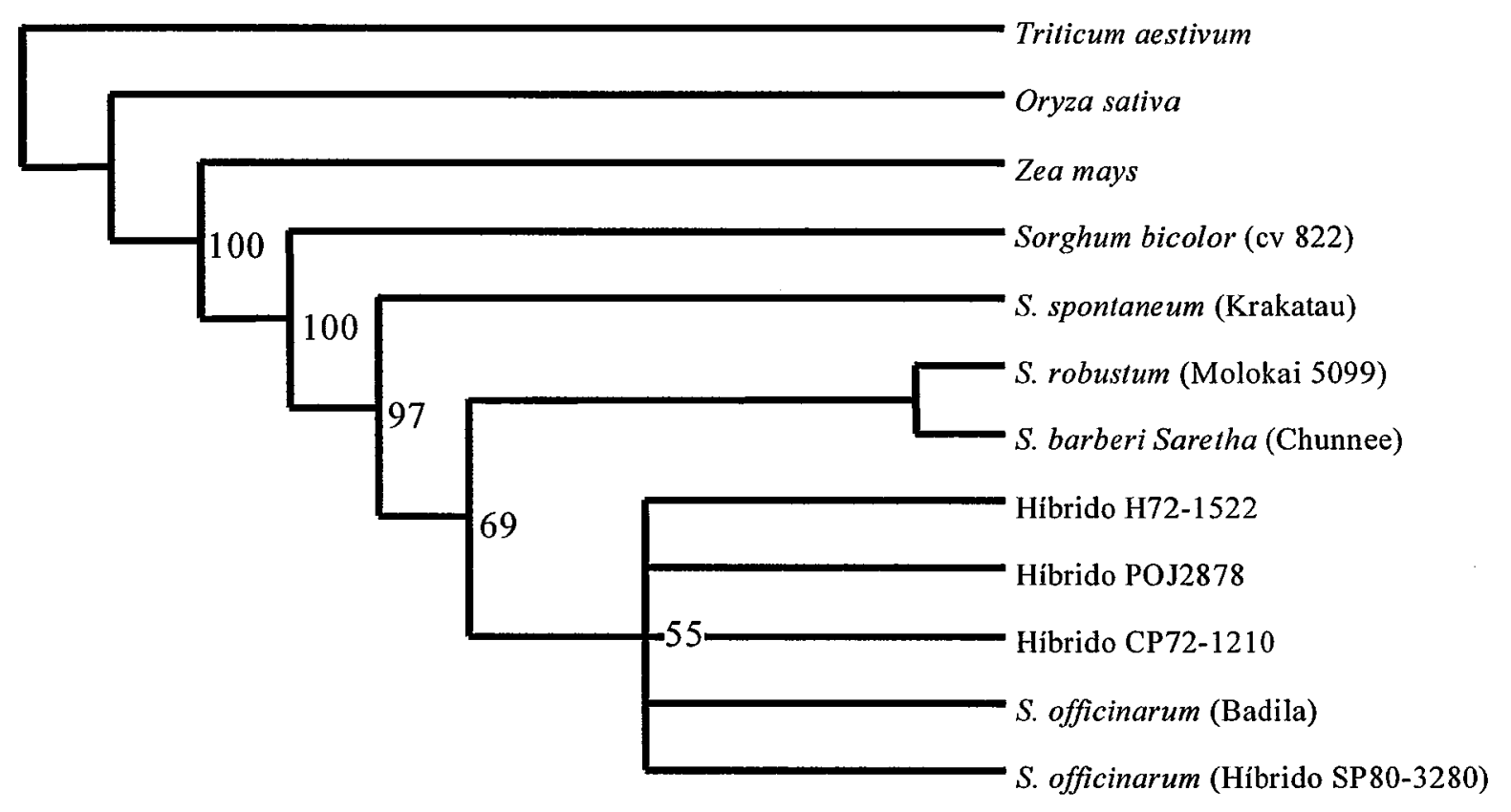

Figura 8 - Relação filogenética entre espécies e híbridos de cana-de-açúcar e outras espécies gramíneas como trigo, arroz, milho e sorgo. Esta é uma árvore de parcimônia considerando a região do ptDNA que inclui somente o gene $n d h F$. Os números são valores de Bootstrap com porcentagens acima de $50 \%$

A Figura 9 apresenta o consenso de 4 árvores filogenéticas geradas pela matriz do alinhamento da região intergênica trnI-trnL. O método utilizado também foi o da máxima parcimônia e o resultado da pesquisa heurística foi: $3.911 \mathrm{pb}$ de caracteres totais; 3.859 caracteres constantes; 52 caracteres variáveis; 15 caracteres não informativos para parcimônia; 37 caracteres potencialmente informativos para parcimônia. 


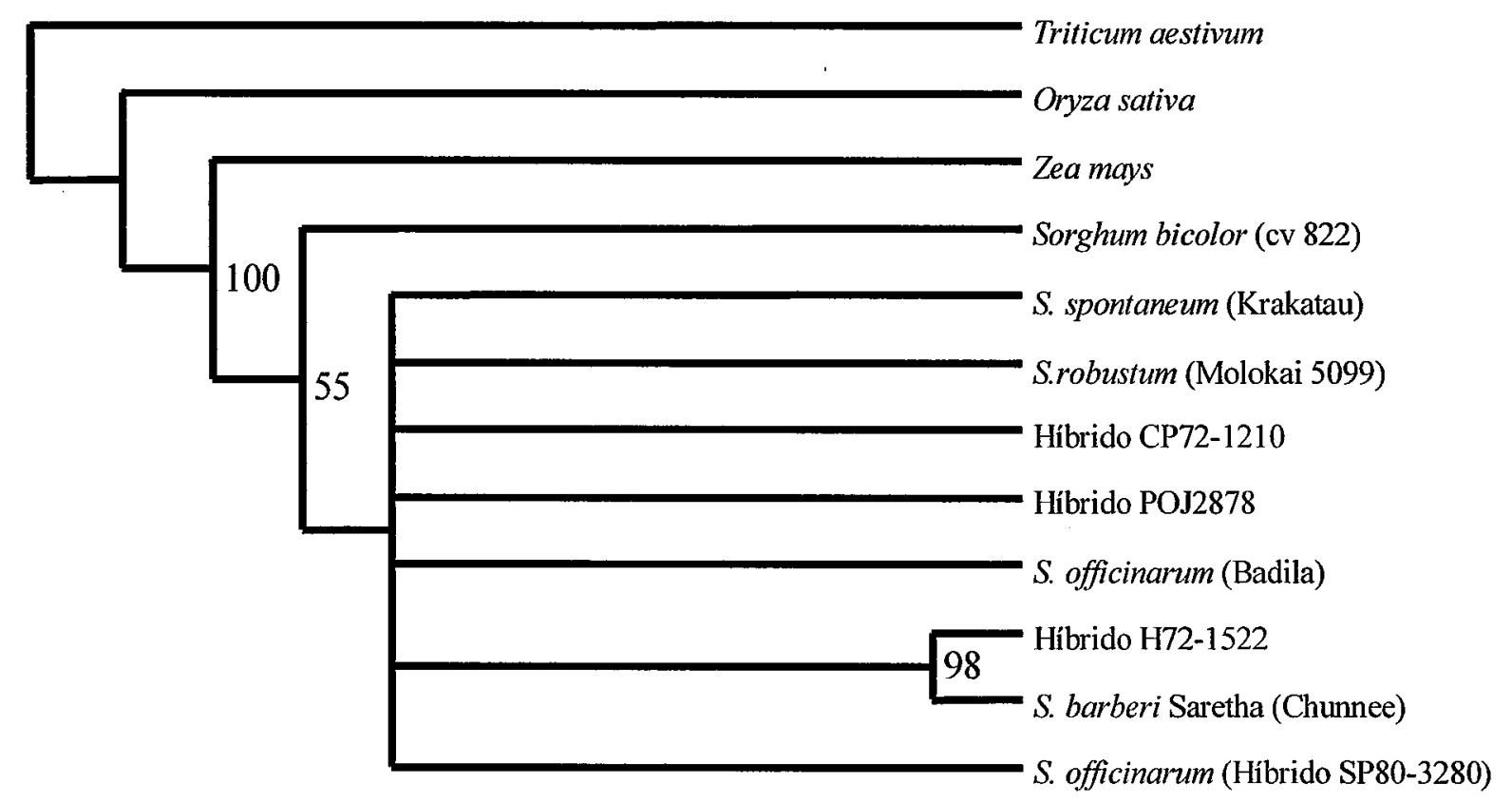

Figura 9 - Relação filogenética entre espécies e híbridos de cana-de-açúcar e outras espécies gramíneas como trigo, arroz, milho e sorgo. Esta é uma árvore de parcimônia considerando a região intergênica $\operatorname{trnI-trnL.~Os~números~são~}$ valores de Bootstrap com porcentagens acima de 50\%

A Figura 10 apresenta o consenso de apenas uma árvore filogenética gerada pela matriz do alinhamento da região intergênica $r b c L$-petA. O método utilizado também foi o da máxima parcimônia e o resultado da pesquisa heurística foi: $6.672 \mathrm{pb}$ de caracteres totais; 5.972 caracteres constantes; 700 caracteres variáveis; 538 caracteres não informativos para parcimônia; 162 caracteres potencialmente informativos para parcimônia. 


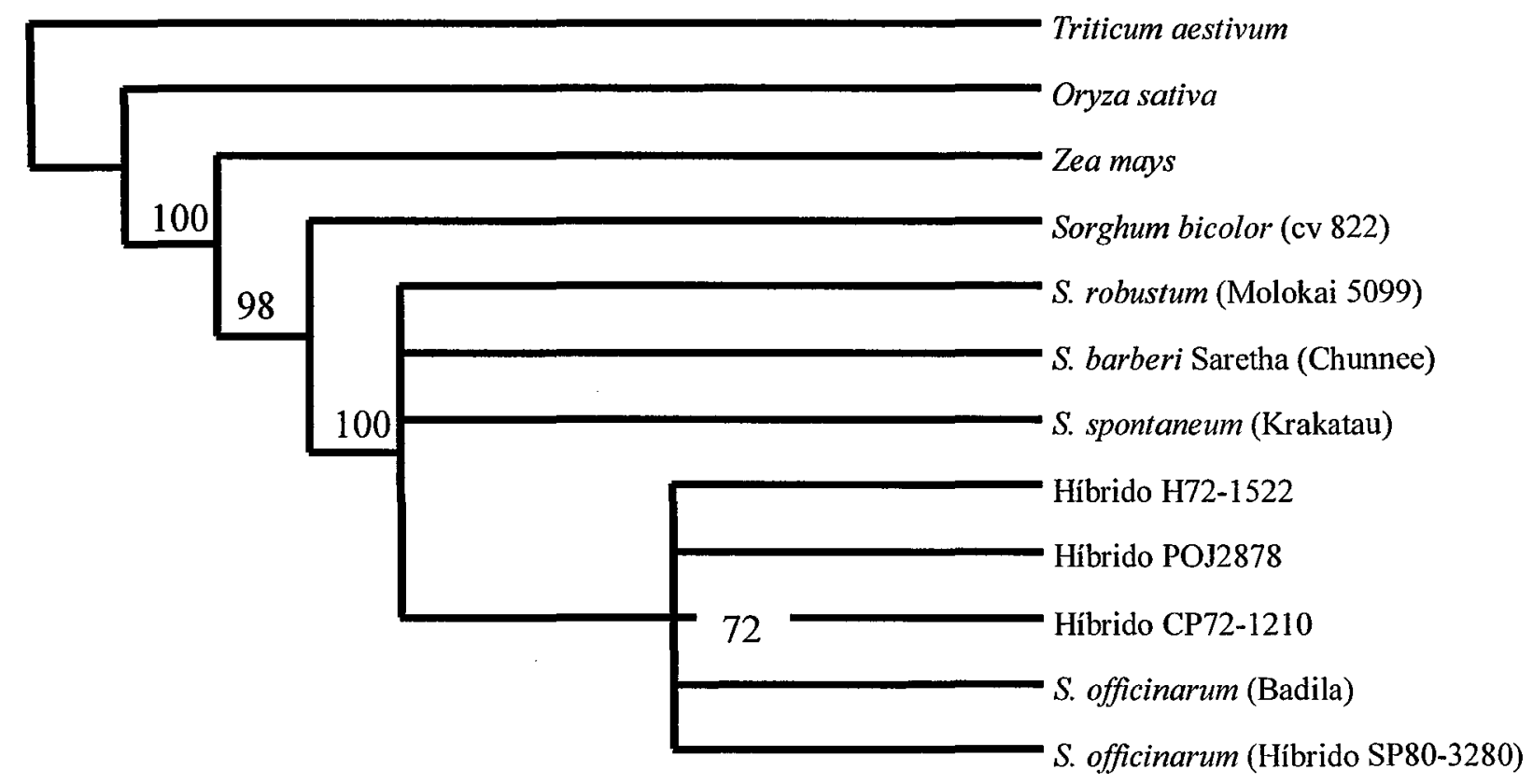

Figura 10 - Relação filogenética entre espécies e híbridos de cana-de-açúcar e outras espécies gramíneas como trigo, arroz, milho e sorgo. Esta é uma árvore de parcimônia considerando a região intergênica $r b c L$-petA. Os números são valores de Bootstrap com porcentagens acima de $50 \%$

As Figuras 8, 9 e 10 indicam que a filogenia molecular das espécies gramíneas, baseando-se nas seqüências de nucleotídeos da região que inclui o gene $n d h F$ e das regiões intergênicas trnI-trnL e rbcL-petA produzem, respectivamente, árvores filogenéticas distintas. Quando se considera a região que inclui o gene $n d h F$ na análise de filogenia, observa-se que as espécies $S$. robustum e $S$. barberi Saretha dividem um ancestral comum e também sugere que os híbridos H72-1522, CP72-1210 e POJ 2878, SP80-3280 e a espécie $S$. officinarum (Badila) formam uma politomia e não apresentam polimorfismo nesta região do ptDNA (Figura 8), sendo que o valor mais baixo de bootstrap é $55 \%$. A herança maternal do cloroplasto de cana-de-açúcar é verificada pela presença desta politomia que agrupa num único ramo os híbridos analisados e a variedade $S$. officinarum (Badila), afirmando que os híbridos realmente apresentam o mesmo plastoma herdado da planta materna $S$. officinarum. 
Ao realizar a análise filogenética se baseando apenas na região intergênica trnItrnL, verifica-se que o híbrido H72-1522 e a espécie $S$. barberi Saretha (Chunnee) apresentam um ancestral comum e a consistência deste ramo é dada pelo valor de bootstrap de $98 \%$. Provavelmente a espécie $S$. barberi Saretha está presente na genealogia do híbrido H72-1522, sendo um dos integrantes desconhecidos dos cruzamentos que o originaram. As outras espécies e híbridos de cana-de-açúcar estudados formam uma politomia não resolvida (Figura 9).

Já a árvore obtida com as sequiências de nucleotídeos da região rbcL-petA sugere que os híbridos H72-1522, CP72-1210 e POJ 2878, SP80-3280 e a espécie $S$. officinarum (Badila) apresentam o mesmo ancestral comum, mostrando que as seqüências de nucleotídeos são muito similares nesta região do ptDNA (Figura 10). Isto reafirma que os híbridos realmente apresentam o mesmo plastoma herdado da planta materna $S$. officinarum e os híbridos comerciais cultivados atualmente apresentam diversidade citoplasmática muito pequena.

A variação genética observada nas regiões alvo dos plastomas de espécies e híbridos do gênero Saccharum (região que inclui o gene $n d h F$ e regiões intergênicas trnI-trnL e rbcL-petA) é representada por um baixo acúmulo de mutações ou reduzida taxa de substituição de nucleotídeos, sugerindo que as espécies do gênero Saccharum apresentam baixo grau de polimorfismo, sendo incapazes em fornecer dados substanciais para estabelecer relações filogenéticas seguras entre os materiais estudados. Isto já foi observado nos trabalhos de Sobral et al. (1994) e Al-Janabi et al. (1994). Os primeiros autores analisaram filogeneticamente mutações nos sítios de restrição enzimática do genoma cloroplastidial na subtribo Saccharinae, mostrando que o gênero Saccharum foi separado em dois clados por um único sítio de mutação: um contendo $S$. spontaneum, e o outro contendo todas as outras espécies de Saccharum e oito híbridos comerciais de várias regiões do mundo. Al-Janabi et al. (1994), analisando filogeneticamente as seqüências de DNA de cloroplasto e mitocôndria, verificaram a ausência de variação entre as variedades comerciais de cana-de-açúcar analisadas (híbridos de Saccharum), sugerindo a existência de uma monocultura citoplasmática mundial, apesar de $S$. spontaneum ser a mais variável das espécies Saccharum. 
Com o interesse de pesquisar marcadores moleculares filogenéticos em cana-deaçúcar, Bacci Junior et al. (2001) analisaram 17 marcadores, incluindo marcadores nucleares, cloroplastidiais e mitocondrialis, em várias espécies do gênero Saccharum e verificaram que os valores de bootstrap e a quantidade de caracteres informativos para parcimônia eram suportados por poucas mutações e a topologia da árvore poderia ser altamente influenciada por homoplasia (caráter compartilhado por dois táxons, mas que não foi herdado do ancestral comum mais recente de ambos). Eles observaram que os genes cloroplastidiais $r b c L$, atpA e rpoA proporcionaram baixa porcentagem de caracteres informativos para parcimônia, apresentada pelo alinhamento destes genes de várias espécies de cana-de-açúcar. Por outro lado os genes rpl16 e rpoC2 apresentaram taxas evolutivas maiores, desde que seus alinhamentos contaram com $49 \%$ e $59 \%$ de caracteres informativos para parcimônia, respectivamente.

No presente trabalho, a região intergênica entre $r b c L$ e petA mostrou-se variável, apresentando divergências típicas entre os plastomas estudados. Já a comparação do modelo de deleção no gene $y c f 2$ e as posições das intersecções entre IR e SSC claramente mostraram que o milho, o sorgo e a cana-de-açúcar estão mais relacionados uns aos outros do que com o trigo e o arroz. Está relação filogenética é suportada pelos trabalhos de Ogihara et al., 1991, Chase et al., 1993, Ohnishi et al., 1999.

\subsection{Análise Comparativa de Edição do mRNA de Sorgo}

Os produtos amplificados a partir do DNA total e cDNA total de sorgo, utilizando os primers desenhados para análise de edição de mRNA (ver Tabela 4, item 3.8), apresentaram os tamanhos esperados em pares de base (Tabela 7). 
Tabela 7. Tamanho dos fragmentos amplificados a partir do DNA e cDNA total de sorgo

\begin{tabular}{ccc}
\hline & \multicolumn{2}{c}{ Tamanho do fragmento amplificado $(\mathrm{pb})$} \\
\cline { 2 - 3 } Genes & Molde DNA total & Molde cDNA total \\
\hline atpA & 355 & 355 \\
$n d h A$ & 2.122 & 1.100 \\
$n d h B$ & 1.816 & 1.117 \\
$n d h D$ & 319 & 319 \\
$n d h F$ & 303 & 303 \\
petB & 315 & 315 \\
$r p l 2$ & 335 & 335 \\
$r p l 20$ & 319 & 319 \\
$r p o B$ & 423 & 423 \\
$r p o C 2$ & 315 & 315 \\
$r p s 14$ & 288 & 288 \\
rps8 & 324 & 324 \\
$y c f 3$ (ORF 170) & 1.043 & 284 \\
\hline
\end{tabular}

Para verificar a possível presença de DNA plastômico contaminante, primers foram desenhados para amplificação da região editada em transcritos dos genes $n d h A$, $n d h B$ e ORF 170 ( $y c f 3)$, que possuem íntron, sendo que cada primer se localiza em um éxon diferente, permitindo a distinção por tamanho dos produtos amplificados a partir do cDNA (sem íntron) e a partir do DNA contaminante (com íntron). 


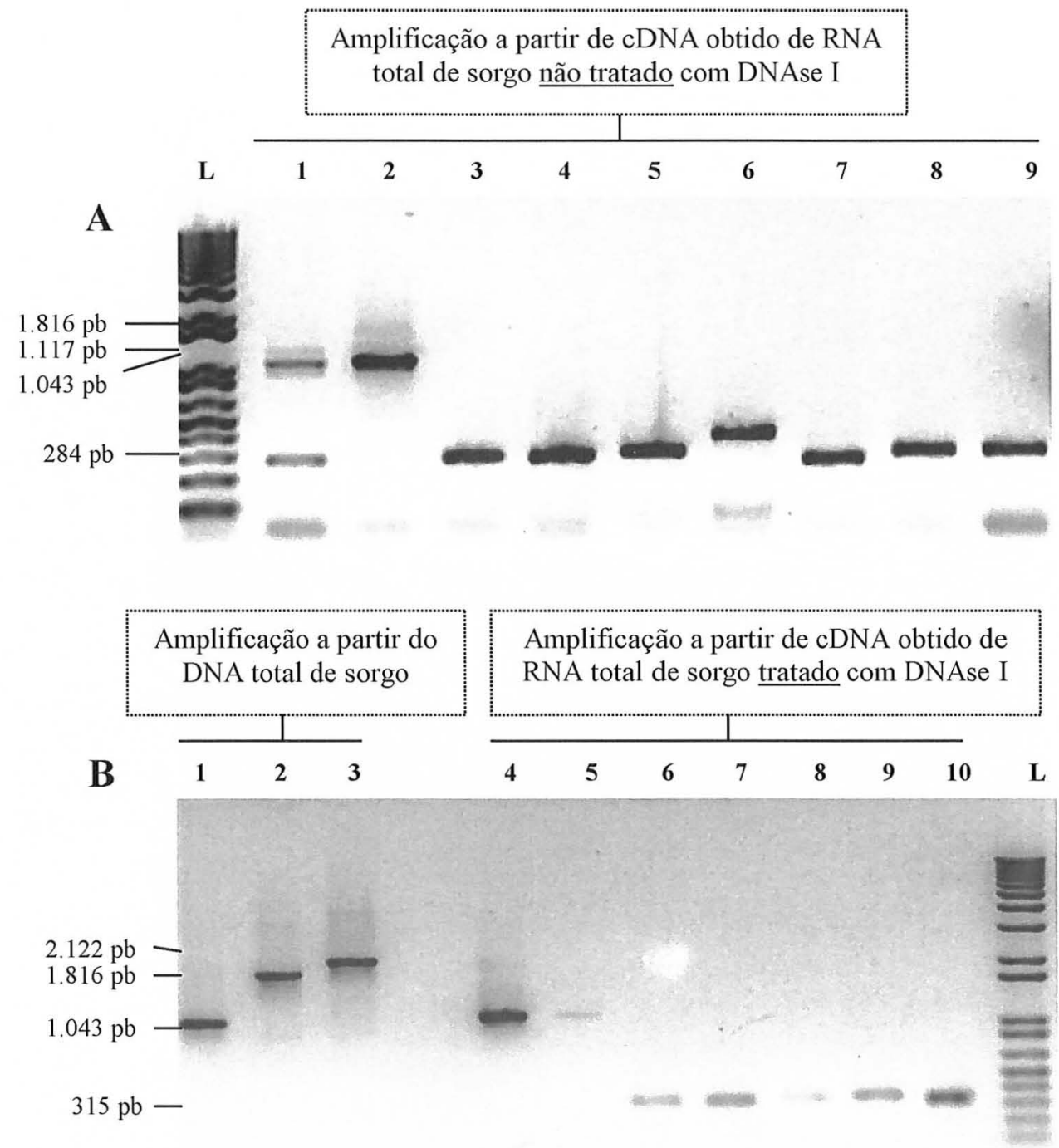

Figura 11 - RT-PCR para análise de edição de transcritos de sorgo. (A) Bandas correspondentes às regiões editadas dos genes $y c f 3(1), n d h B(2), r p o C 2(3), n d h D$ (4), rpl2 (5), rpoB (6), rps 14 (7), $n d h F(8), r p l 20$ (9) amplificadas a partir do cDNA obtido de RNA não tratado com DNAse I. (B) Bandas correspondentes às regiões amplificadas do DNA total das regiões dos genes $y c f 3$ (1), $n d h B(2), n d h A$ (3) e a partir do cDNA obtido de RNA tratado com DNAse I das regiões editadas dos genes $n d h B(4), n d h A(5), p e t B(6), n d h D(7), r p l 2$ (8), atpA (9), rps8 (10). L = 1 kb DNA ladder plus (Invitrogen Life Technologies)

A Figura 11 apresenta dois géis de agarose $1 \%\left(\right.$ TAE $\left.1 \mathrm{x}, 3 \mathrm{~V} \cdot \mathrm{cm}^{-1}\right)$. Analisando a Figura 11-A, verifica-se que a amostra 1 (região do gene $y c f 3$ ) apresentou bandas amplificadas a partir do DNA plastômico contaminante (1.043 pb - tamanho inclui o 
íntron do gene $y c f 3$ ) e do cDNA ( $284 \mathrm{pb}$ ), havendo necessidade de tratar o RNA total de sorgo com DNAse I para eliminar o DNA contaminante. $\mathrm{Na}$ amostra 2 (região do gene $n d h B)$ não foi evidente a presença da banda amplificada a partir do DNA contaminante (1.816 pb - tamanho inclui o íntron do gene $n d h B)$. As outras amostras presentes na Figura 11-A possivelmente contêm bandas amplificadas a partir do DNA plastômico e do cDNA, entretanto estes fragmentos amplificados apresentam o mesmo tamanho, pois são regiões sem íntron. Na Figura 11-B estão presentes algumas das amplificações realizadas a partir do DNA total de sorgo e do cDNA obtido de RNA total de sorgo tratado com DNAse I. Nesta figura observa-se que houve amplificação de bandas de tamanho esperado (ver Tabela 5). Um exemplo são as amostra 2 e 4 (região que inclui o gene $n d h B$ ) que foram amplificadas, respectivamente, a partir do DNA total de sorgo (1.816 pb - inclui o íntron) e a partir do cDNA obtido de RNA tratado com DNAse I (1.117 pb - sem íntron). Outro exemplo são as amostra 3 e 5 (região que inclui o gene $n d h A$ ) que foram amplificadas a partir do DNA total de sorgo (amostra 3: tamanho banda de $2122 \mathrm{pb}$ - inclui o íntron) e a partir do cDNA obtido de RNA tratado com DNAse I (amostra 5: tamanho banda de $1.100 \mathrm{pb}$ - sem íntron).

As sequiências de nucleotídeos dos DNAs e cDNAs relativas às regiões dos genes atp $A, n d h A, n d h B, n d h D, n d h F$, petB, rpl2, rpl20, rpoB, rpoC2, rpsl4, rps8 e ycf3 de sorgo foram analisadas e confirmadas quanto à qualidade dos cromatogramas gerados (programa Vector NTI Suíte 6.0 e programa acessório ClustalW no BioEdit). O Anexo E apresenta os alinhamentos que incluem as sequiências de nucleotídeos dos genes amplificados a partir do DNA total de sorgo (controles) comparadas com as seqüências de nucleotídeos amplificadas dos respectivos cDNAs obtidos a partir do RNA tratado com DNAse I. Também foram incluídas nestes alinhamentos as seqüências de nucleotídeos destes genes dos plastomas de milho $\left(\mathrm{N}^{\circ}\right.$ de acesso do plastoma de Zea mays no NCBI: X86563) e de cana-de-açúcar (homepage do plastoma de S. officinarum, SP80-3280: http://sucest.lad.dcc.unicamp.br/sc-chlroplasto), além da seqüências de nucleotídeos dos cDNAs de milho (Maier et al., 1995) e cana-de-açúcar (Calsa Junior, 2001). 
A Tabela 8 apresenta os sítios de edição do mRNA detectados no plastoma de sorgo (Sorghum bicolor) comparados aos sítios presentes em cana-de-açúcar (Calsa Junior, 2001) e milho (Maier et al., 1995). Ao analisar os alinhamentos das seqüências destes genes para verificar a edição em sorgo, observou-se que entre as 25 posições já descritas para tais genes no plastoma de milho (Zea mays), 24 apresentam transição de C por U. Dos 2 sítios de edição já detectados para o gene ycf3 (ORF 170), o códon presente na posição 15 do plastoma de milho não apresenta edição nos plastomas de sorgo e cana-de-açúcar (Tabela 8). O cloroplasto de cana-de-açúcar, estudado por Calsa Jr. (2001), apresenta 23 posições de transição de $\mathrm{C}$ por $\mathrm{U}$ dos 25 sítios de edição analisados. As transições mais freqüentes ( $\overline{\mathrm{uCa}}$ para $\mathrm{uUa}_{i} \mathrm{cCa}$ para cUa) são observadas em milho, mantendo a tendência para a alteração na segunda posição no códon. As análises mostram que milho, sorgo e cana-de-açúcar seguem o mesmo modelo de edição de RNA no plastoma, exceto para rpoB (posição 206 do códon no plastoma de milho não apresenta edição no plastoma de cana-de-açúcar) e ycf3 (posição 15 do códon no plastoma de milho não apresenta edição nos plastomas de sorgo e cana-de-açúcar), e a hipótese seria de que praticamente as mesmas necessidades de edição do RNA existentes nos cloroplastos de milho são observadas nestas organelas de sorgo e cana-de-açúcar (Tabela 8).

Analisando a Tabela 8, verifica-se que nos sítios em que ocorrem as edições todos os códons apresentam mudança de aminoácidos, sendo que a mais comum é a alteração do aminoácido serina pelo aminoácido leucina. A edição do mRNA, um processo de modificação pós-transcricional, representa uma forma de controle genético regulatório nas células eucarióticas. A edição freqüentemente restabelece os resíduos de aminoácidos conservados nas proteínas correspondentes e assim representam uma função importante, eliminando os erros nas seqüências ao nível de mRNA. 
Tabela 8. Sítios de edição do mRNA detectados no plastoma de sorgo (Sorghum bicolor) e comparados aos sítios presentes em cana-de-açúcar (Calsa Junior, 2001) e milho (Maier et al., 1995)

\begin{tabular}{|c|c|c|c|c|c|c|}
\hline \multirow[t]{2}{*}{ Gene } & \multirow{2}{*}{$\begin{array}{c}\text { Posição do códon no } \\
\text { ptDNA de milho }\end{array}$} & \multirow{2}{*}{$\begin{array}{l}\text { Códon } \\
\text { editado }\end{array}$} & \multirow{2}{*}{$\begin{array}{l}\text { Mudança no } \\
\text { aminoácido }\end{array}$} & \multicolumn{3}{|c|}{ Espécies $^{a}$} \\
\hline & & & & $\begin{array}{l}\text { Sorghum } \\
\text { bicolor }\end{array}$ & $\begin{array}{l}\text { Saccharum } \\
\text { officinarum }\end{array}$ & Zea mays \\
\hline atp $A$ & 383 & $\mathrm{uCa}$ & $\mathrm{S} \rightarrow \mathrm{L}$ & + & + & + \\
\hline$n d h A$ & $\begin{array}{c}17 \\
158 \\
188 \\
357\end{array}$ & $\begin{array}{l}\mathrm{uCg} \\
\mathrm{uCa} \\
\mathrm{uCa} \\
\mathrm{uCc}\end{array}$ & $\begin{array}{l}\mathrm{S} \rightarrow \mathrm{L} \\
\mathrm{S} \rightarrow \mathrm{L} \\
\mathrm{S} \rightarrow \mathrm{L} \\
\mathrm{S} \rightarrow \mathrm{F}\end{array}$ & $\begin{array}{l}+ \\
+ \\
+ \\
+\end{array}$ & $\begin{array}{l}+ \\
+ \\
+ \\
+\end{array}$ & $\begin{array}{l}+ \\
+ \\
+ \\
+\end{array}$ \\
\hline$n d h B$ & $\begin{array}{l}156 \\
196 \\
204 \\
246 \\
277 \\
494\end{array}$ & $\begin{array}{l}\mathrm{cCa} \\
\mathrm{Cau} \\
\mathrm{uCa} \\
\mathrm{cCa} \\
\mathrm{uCa} \\
\mathrm{cCa}\end{array}$ & $\begin{aligned} \mathrm{P} & \rightarrow \mathrm{L} \\
\mathrm{H} & \rightarrow \mathrm{Y} \\
\mathrm{S} & \rightarrow \mathrm{L} \\
\mathrm{P} & \rightarrow \mathrm{L} \\
\mathrm{S} & \rightarrow \mathrm{L} \\
\mathrm{P} & \rightarrow \mathrm{L}\end{aligned}$ & $\begin{array}{l}+ \\
+ \\
+ \\
+ \\
+ \\
+\end{array}$ & $\begin{array}{l}+ \\
+ \\
+ \\
+ \\
+ \\
+\end{array}$ & $\begin{array}{l}+ \\
+ \\
+ \\
+ \\
+ \\
+\end{array}$ \\
\hline$n d h D$ & 293 & $\mathrm{uCa}$ & $\mathrm{S} \rightarrow \mathrm{L}$ & + & + & + \\
\hline$n d h F$ & 21 & $\mathrm{uCa}$ & $\mathrm{S} \rightarrow \mathrm{L}$ & + & + & + \\
\hline petB & 204 & $\mathrm{cCa}$ & $\mathrm{P} \rightarrow \mathrm{L}$ & + & + & $+\ldots$ \\
\hline$r p l 2$ & 1 & $\mathrm{aCg}$ & $\mathrm{T} \rightarrow \mathrm{M}$ & + & + & + \\
\hline rpl20 & 103 & $\mathrm{uCa}$ & $\mathrm{S} \rightarrow \mathrm{L}$ & + & $t$ & + \\
\hline$r p o B$ & $\begin{array}{l}156 \\
182 \\
187 \\
206\end{array}$ & $\begin{array}{l}\mathrm{uCg} \\
\mathrm{uCa} \\
\mathrm{uCg} \\
\mathrm{cCg}\end{array}$ & $\begin{array}{l}\mathrm{S} \rightarrow \mathrm{L} \\
\mathrm{S} \rightarrow \mathrm{L} \\
\mathrm{S} \rightarrow \mathrm{L} \\
\mathrm{P} \rightarrow \mathrm{L}\end{array}$ & $\begin{array}{l}+ \\
+ \\
+ \\
+\end{array}$ & $\begin{array}{l}+ \\
+ \\
+ \\
-\end{array}$ & $\begin{array}{l}+ \\
+ \\
+ \\
+\end{array}$ \\
\hline rpoc2 & 925 & $\mathrm{uCg}$ & $\mathrm{S} \rightarrow \mathrm{L}$ & + & + & + \\
\hline$r p s 14$ & 27 & $\mathrm{uCa}$ & $\mathrm{S} \rightarrow \mathrm{L}$ & + & + & + \\
\hline rps 8 & 61 & $\mathrm{uCa}$ & $\mathrm{S} \rightarrow \mathrm{L}$ & + & + & + \\
\hline$y c f 3$ & $\begin{array}{l}15 \\
62\end{array}$ & $\begin{array}{l}\mathrm{uCc} \\
\mathrm{aCg}\end{array}$ & $\begin{array}{l}\mathrm{S} \rightarrow \mathrm{F} \\
\mathrm{T} \rightarrow \mathrm{M}\end{array}$ & - & $\begin{array}{l}- \\
+\end{array}$ & $\begin{array}{l}+ \\
+\end{array}$ \\
\hline
\end{tabular}

${ }^{a}$ Abreviações: +, edição; -, não editado.

Como apresentado, além da significativa similaridade estrutural entre os plastomas das espécies de cana-de-açúcar, milho e sorgo, uma possível identidade entre os mecanismos de regulação da expressão gênica plastidial, especialmente em relação ao mecanismo de edição de mRNA. 


\section{CONCLUSÕES}

Com base nos resultados apresentados, podemos concluir:

- A variabilidade genética entre os genomas cloroplastidiais de espécies e híbridos do gênero Saccharum (S. officinarum variedade Badila, $S$. barberi Saretha variedade Chunnee, S. robustum variedade Molokai 5099, S. spontaneum variedade Krakatau e híbridos SP80-3280, POJ 2878, CP72-1210 e H72-1522) nas regiões estudadas (região $16 S r D N A$, regiões intergênicas $\operatorname{trnI-trnL}$ e $r b c L$ petA, genes $p s b A, n d h H, n d h F$ e rpl22 que se encontram nas intersecções do plastoma ou próximos delas) apresentou baixo grau de polimorfismo.

- A espécie S. spontaneum (Krakatau) apresentou maior taxa de mutação ao nível de nucleotídeo nas regiões intergênicas $\operatorname{trnI-trnL}$ e $r b c L$-petA, e na região que inclui o gene $n d h F$.

- A comparação do modelo de deleção do gene $y c f 2$, localizado entre os genes trnI e $\operatorname{trn} L$, e as posições das intersecções entre IR e SSC do plastoma mostraram que as espécies de cana-de-açúcar, milho e sorgo estão mais relacionadas umas as outras do que com as espécies de trigo e arroz.

- A região intergênica $r b c L$-petA mostrou-se variável ao nível de nucleotídeos, apresentando divergências típicas entre os plastomas das espécies Poaceae estudadas. 
- Existe maior identidade entre os plastomas de cana-de-açúcar, sorgo e milho tanto nas regiões codificadoras como intergênicas, o que sugere uma evolução comum entre eles, além de uma possível identidade entre os mecanismos de regulação da expressão gênica plastidial, especialmente em relação ao mecanismo de edição do mRNA. A maior divergência ao nível de nucleotídeo ocorreu nos plastomas de arroz e trigo que não dividem este alto nível de similaridade.

- A região que inclui o gene $n d h F$ e as regiões intergênicas trnI-trnL e $r b c L$-petA podem se tornar marcadores preferenciais para estudar a posição sistemática de cultivares de cana-de-açúcar de interesse em relação às espécies da família Poaceae.

- Pela análise das seqüências de nucleotídeos das regiões selecionadas do plastoma foi possível concluir que não existe diversidade genética citoplasmática entre as espécies e híbridos de cana-de-açúcar estudados. 
ANEXOS 

ANEXO A - Genealogias dos híbridos selecionados para o estudo (SP80-3280, POJ2878, CP72-1210 e H72-1522). 


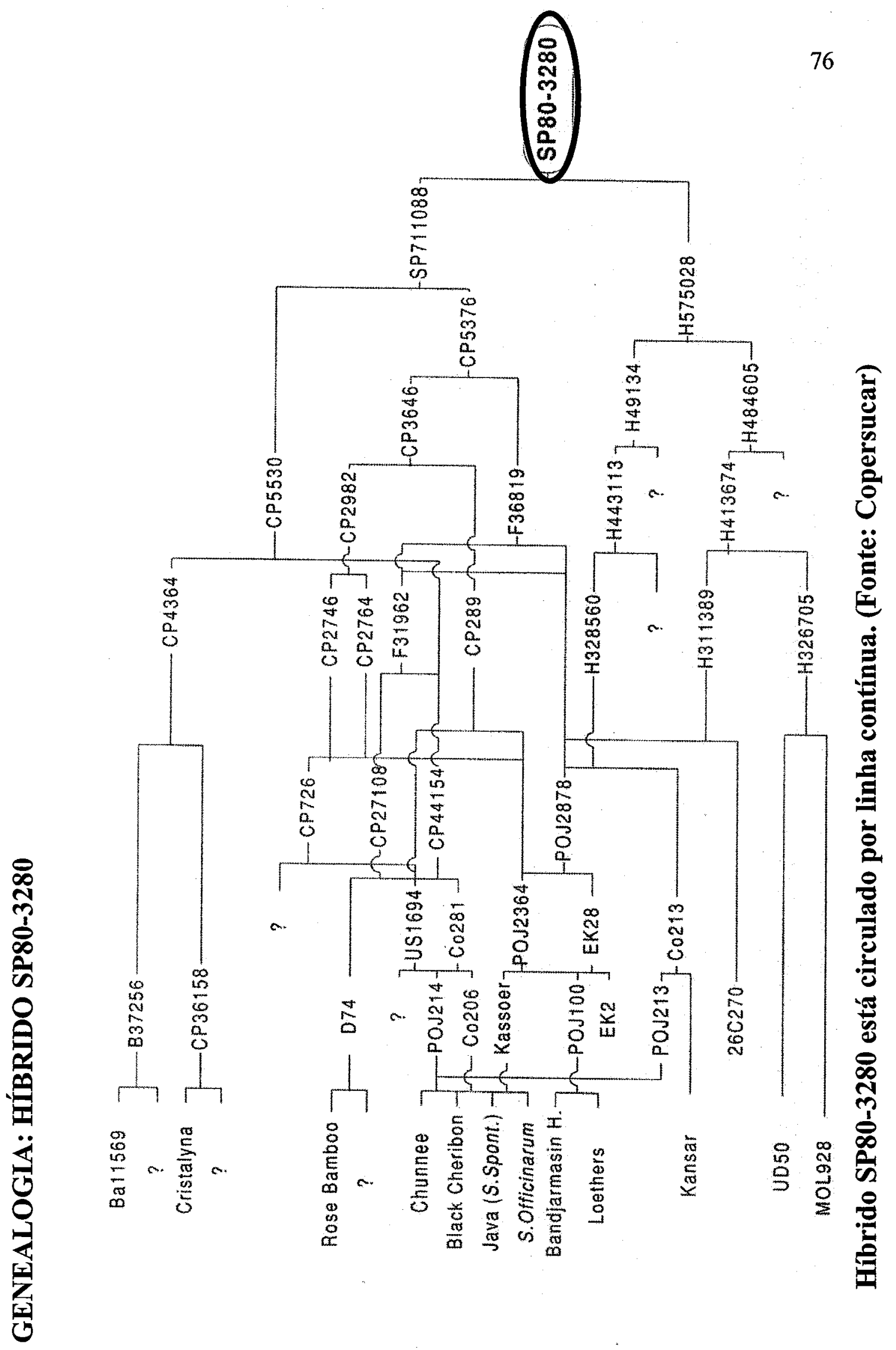




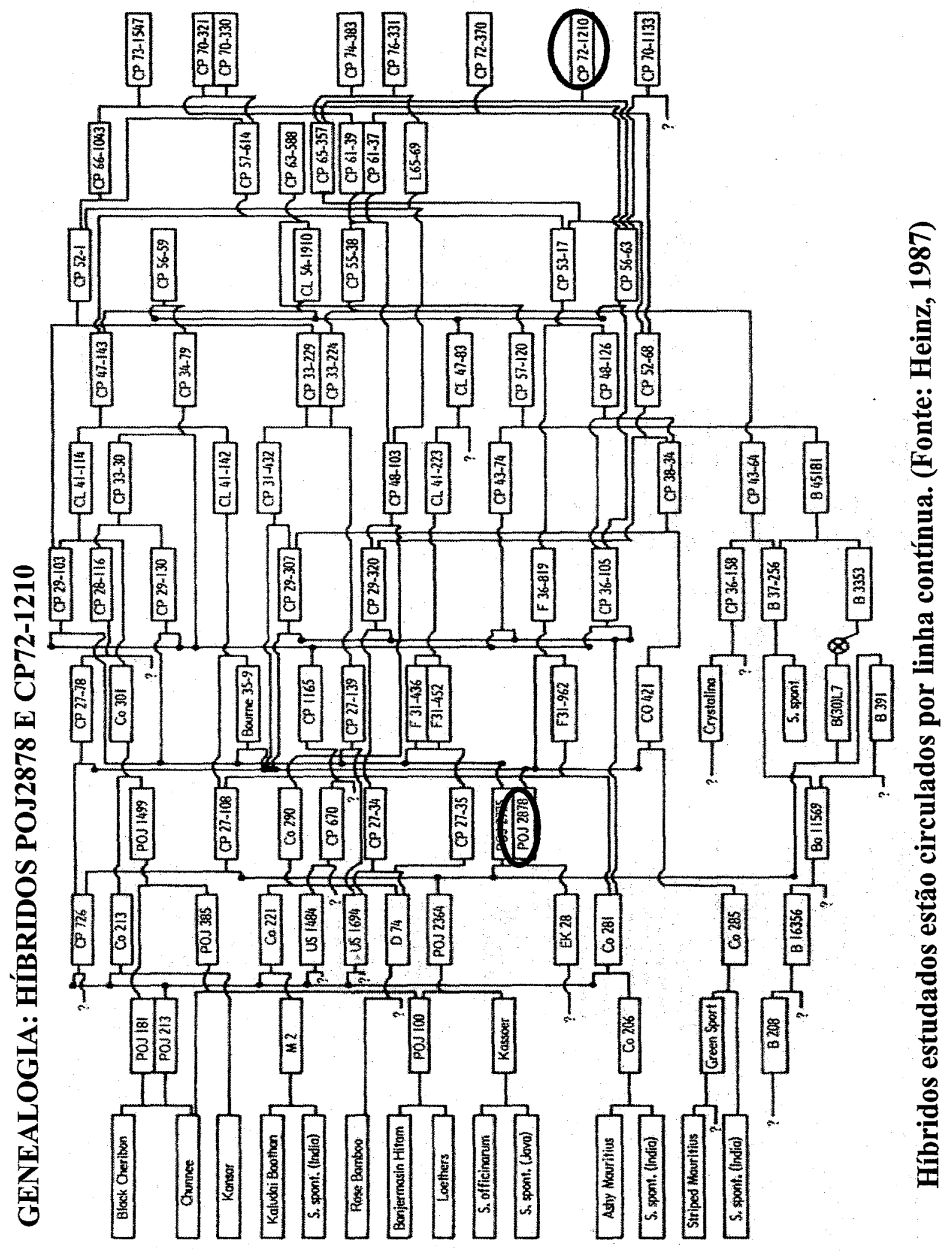




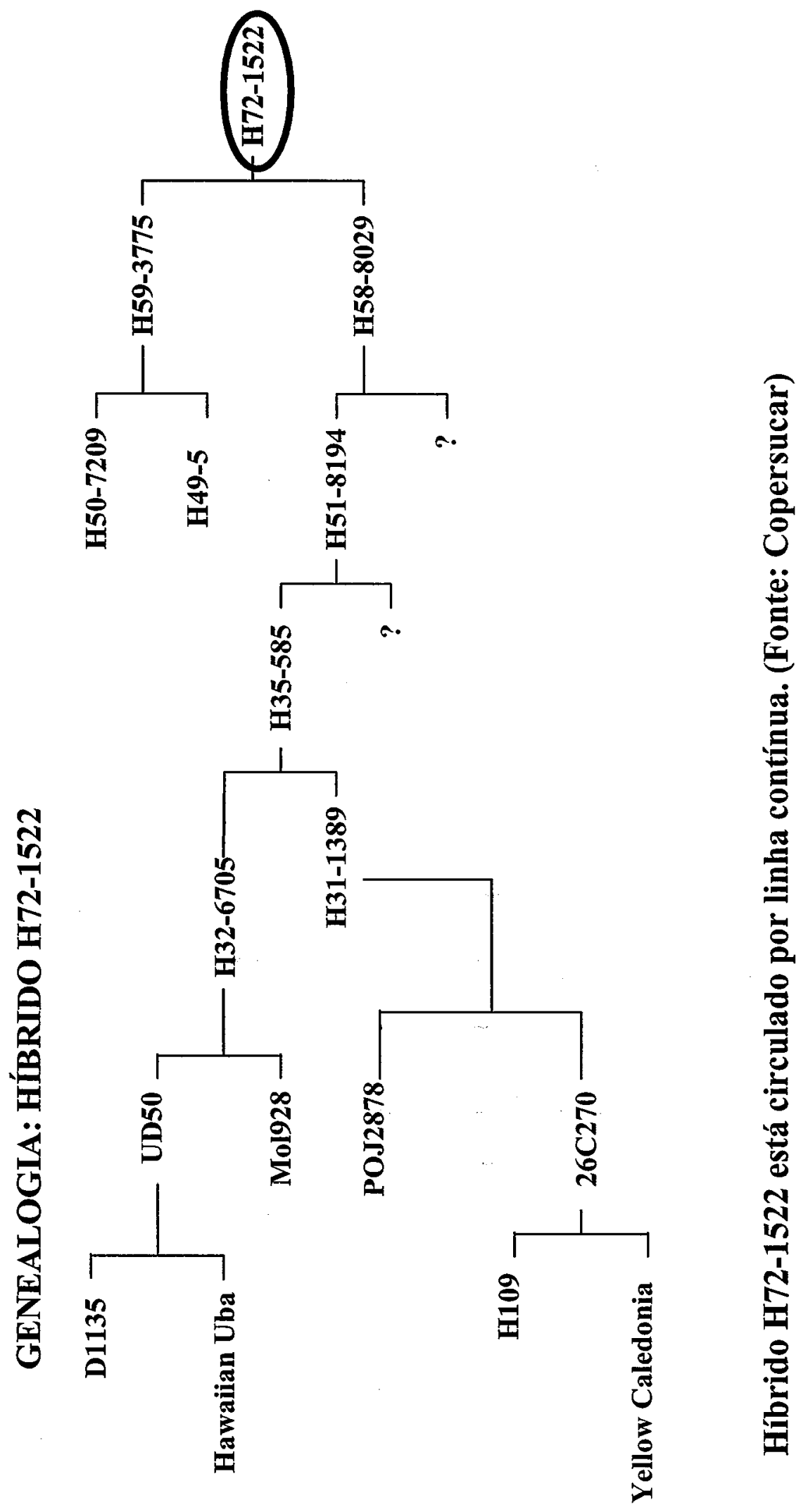


ANEXO B - Alinhamentos da região que inclui o gene $n d h F$. Os códons de iniciação e terminação de cada gene estão marcados em cinza. $\mathrm{O}$ nome do gene está próximo dos códons de iniciação e terminação. As linhas contínuas que estão ao redor das bases nitrogenadas delimitam o gene do início ao fim. Os pontos alinhados representam as mesmas bases nitrogenadas do híbrido SP80-3280. Os traços representam os gaps (deleções de bases nitrogenadas). As mutações são apresentadas pelas bases nitrogenadas em negrito que diferem do híbrido SP80-3280. 


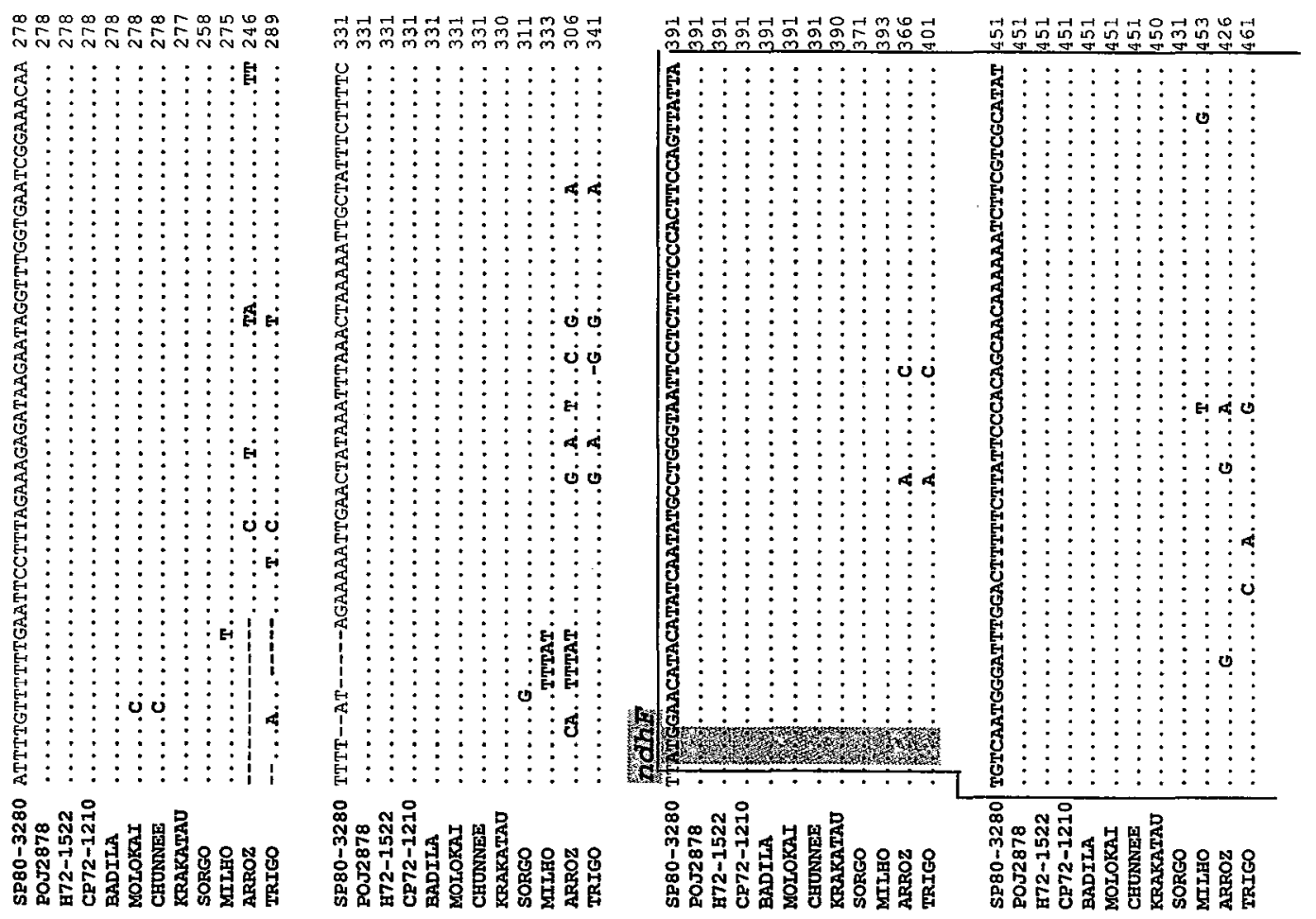

80

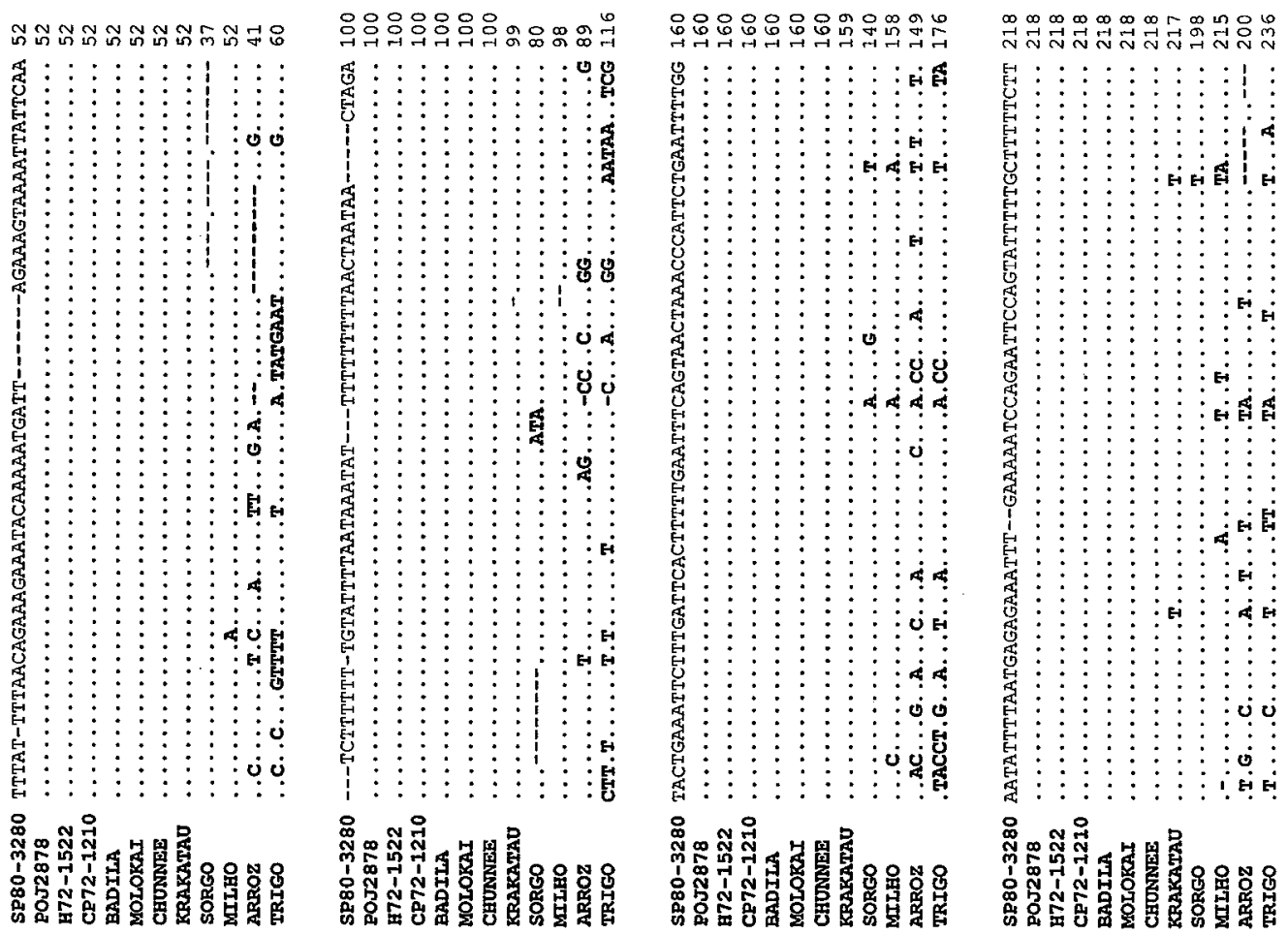



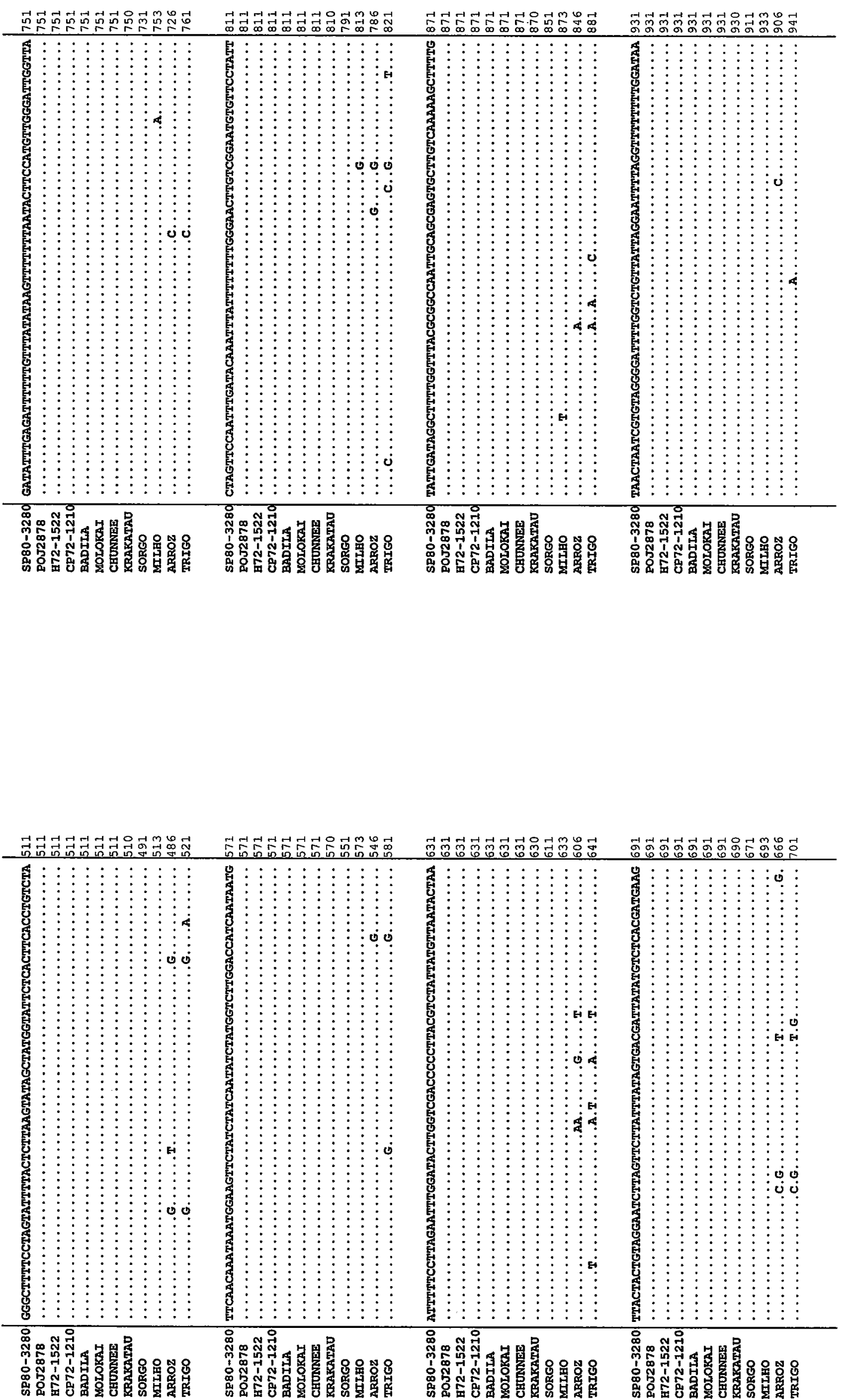

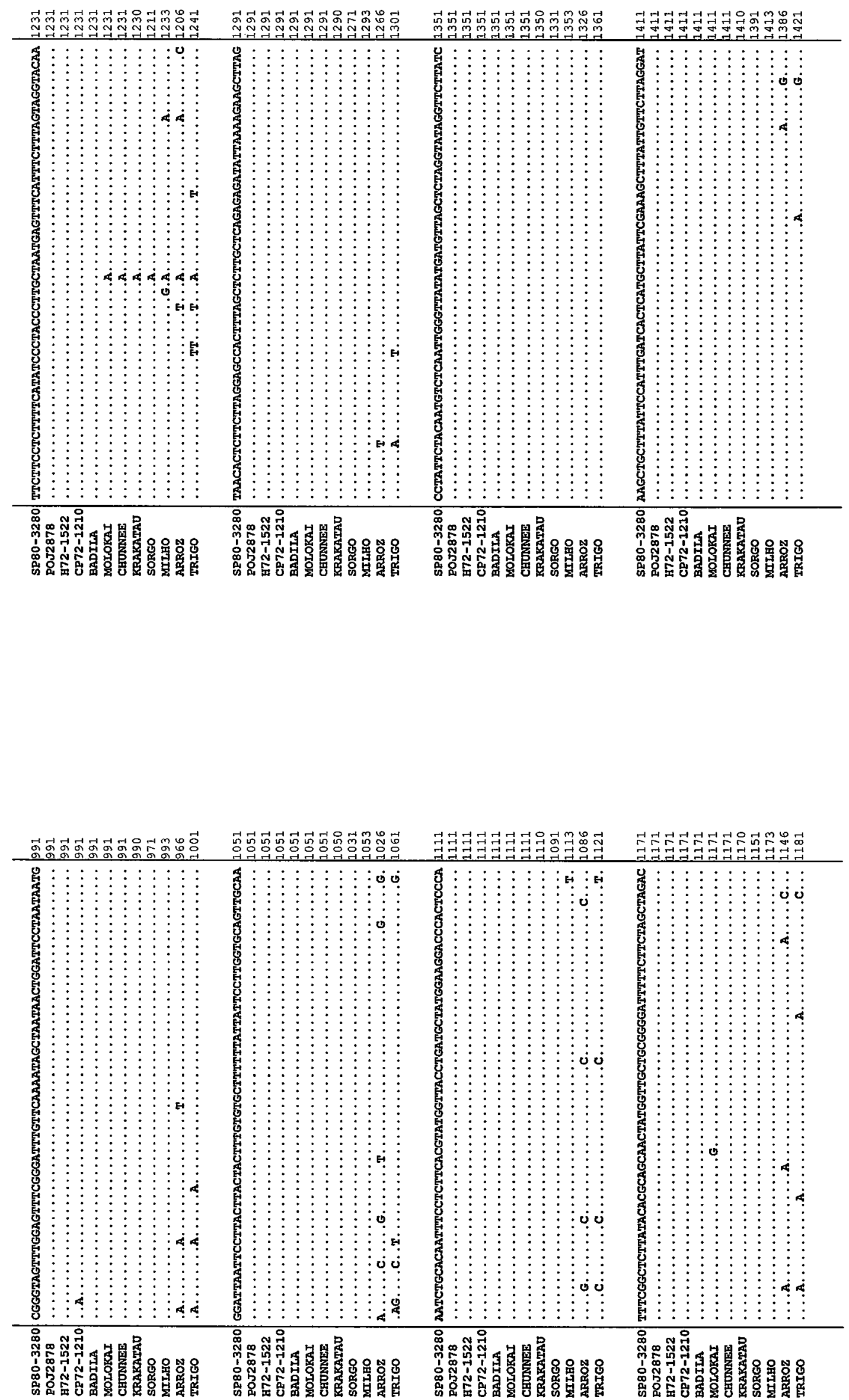


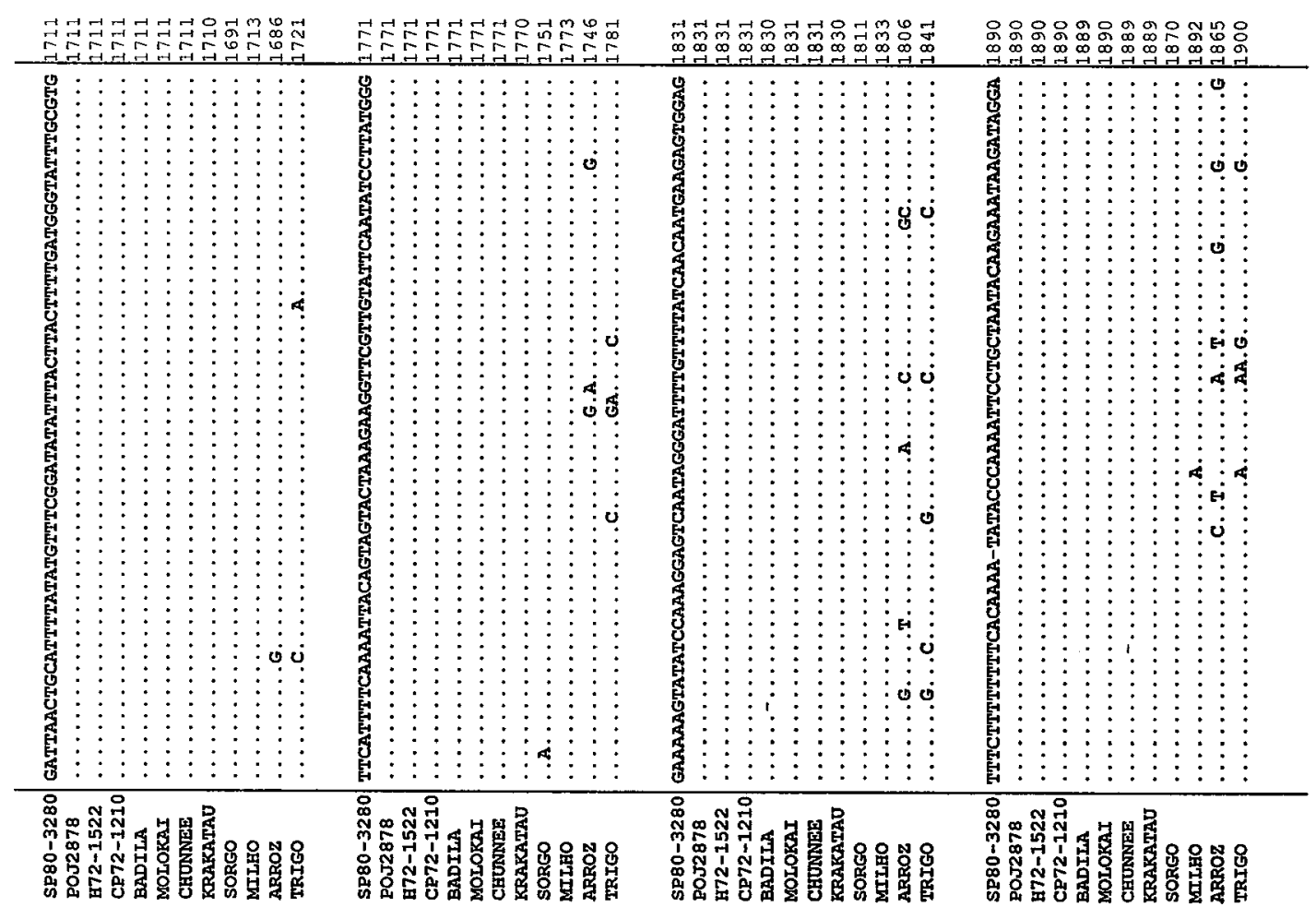

83

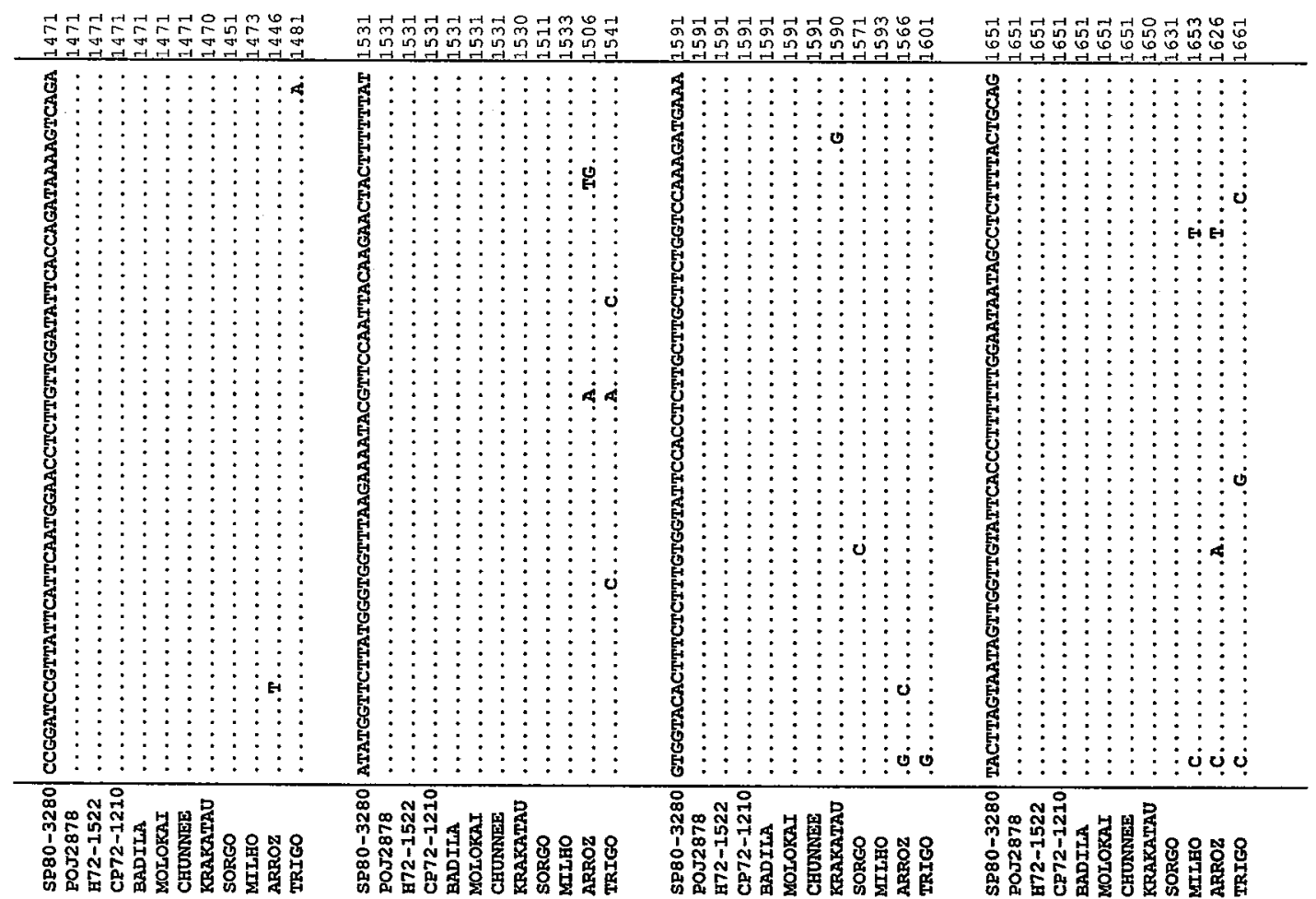




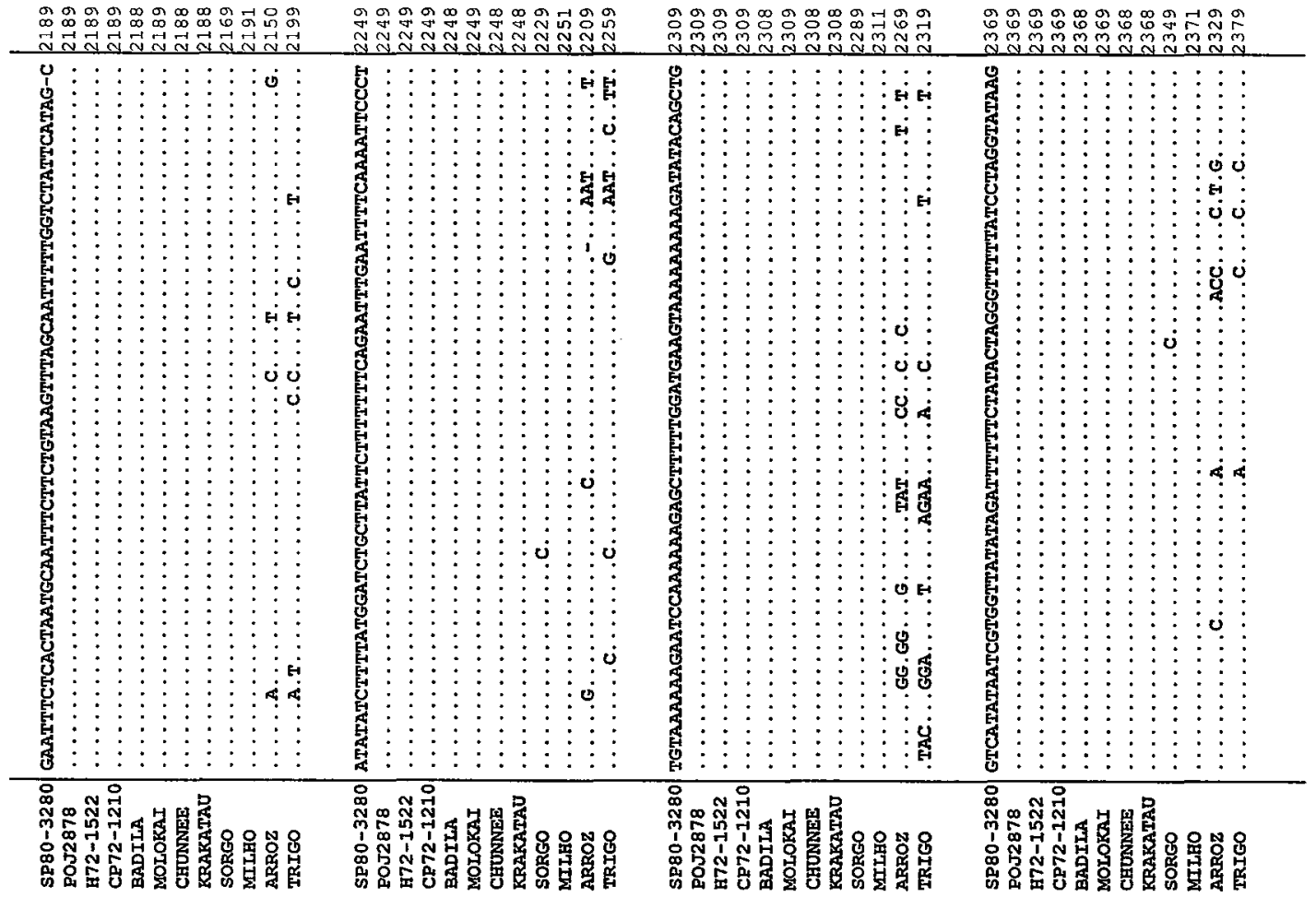

84

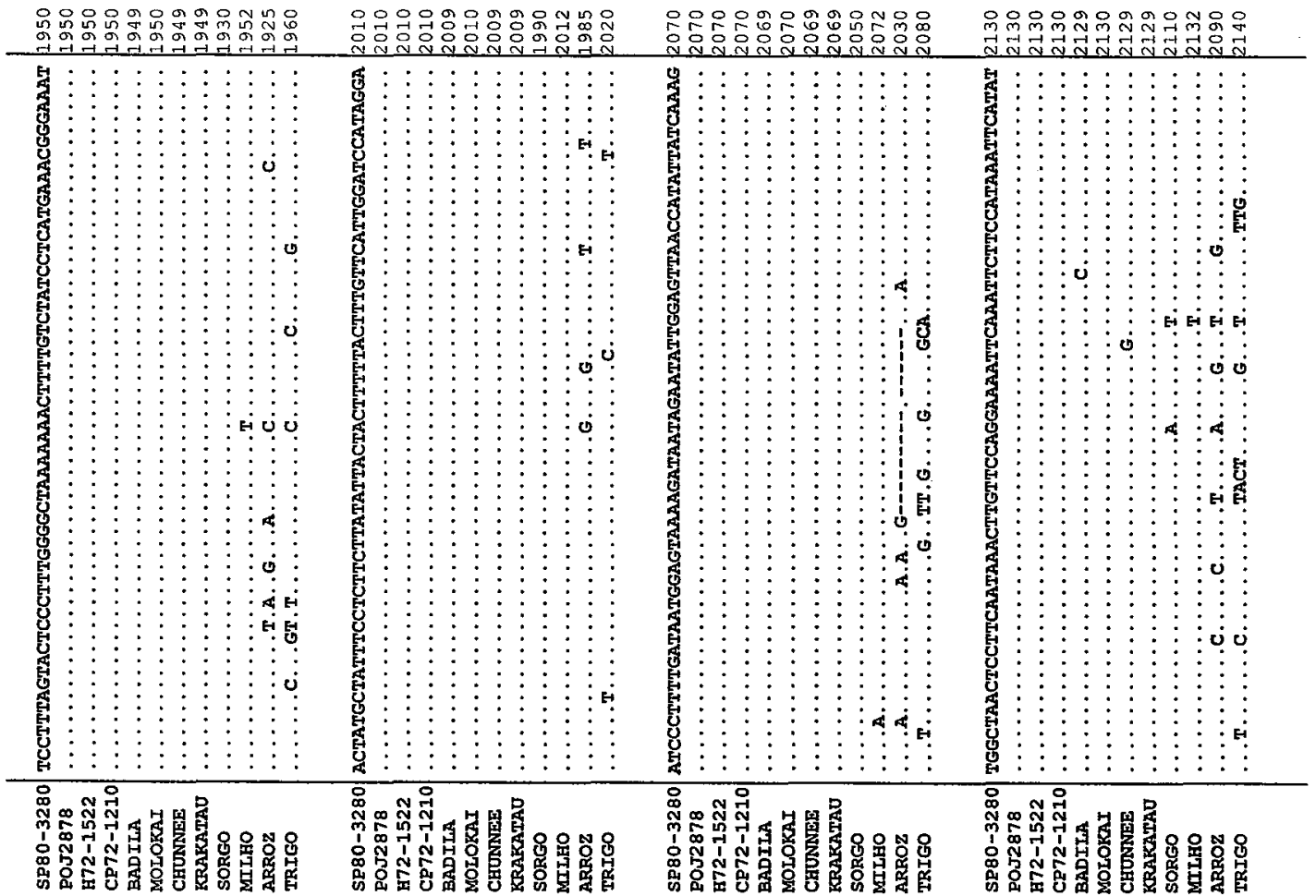



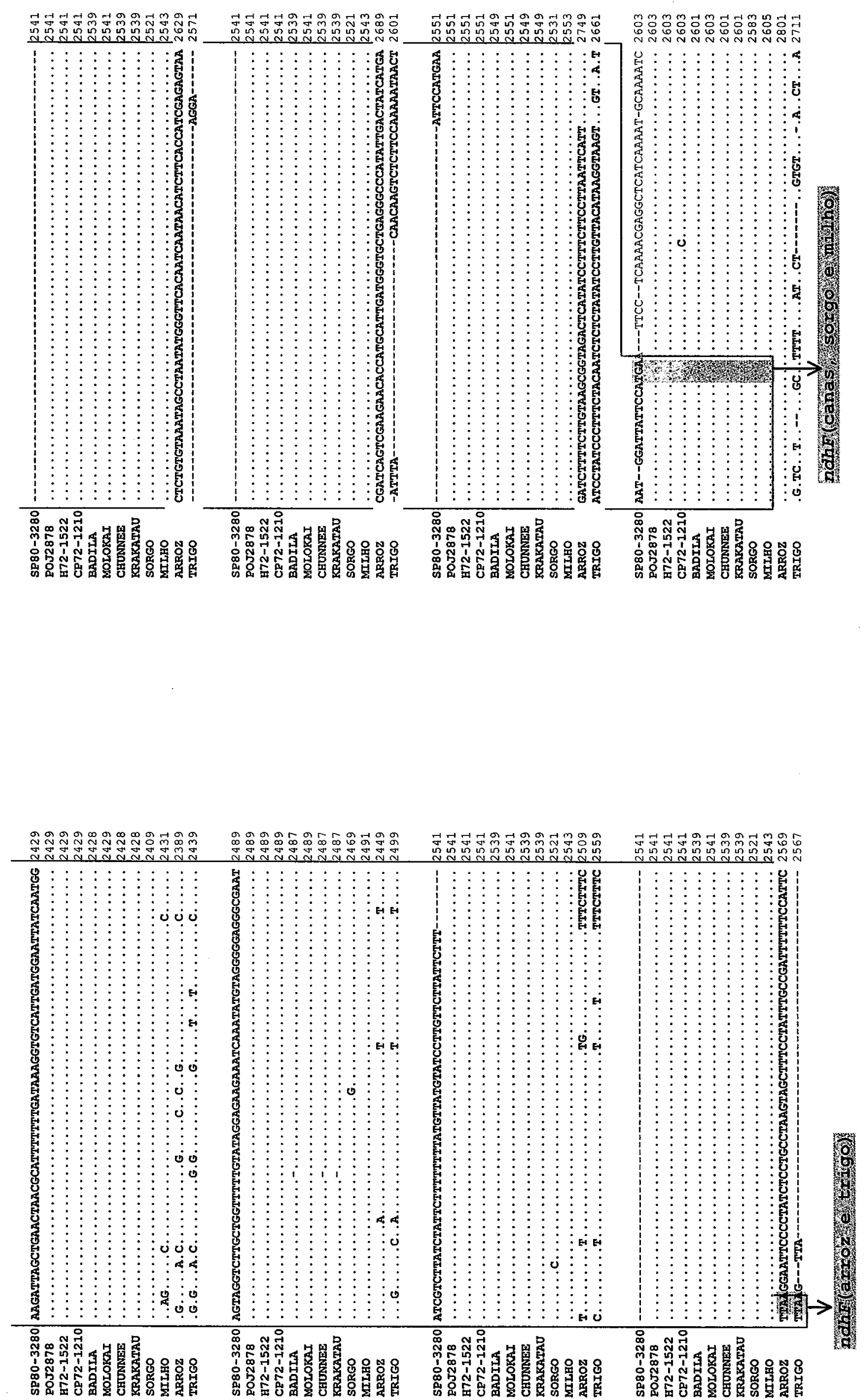


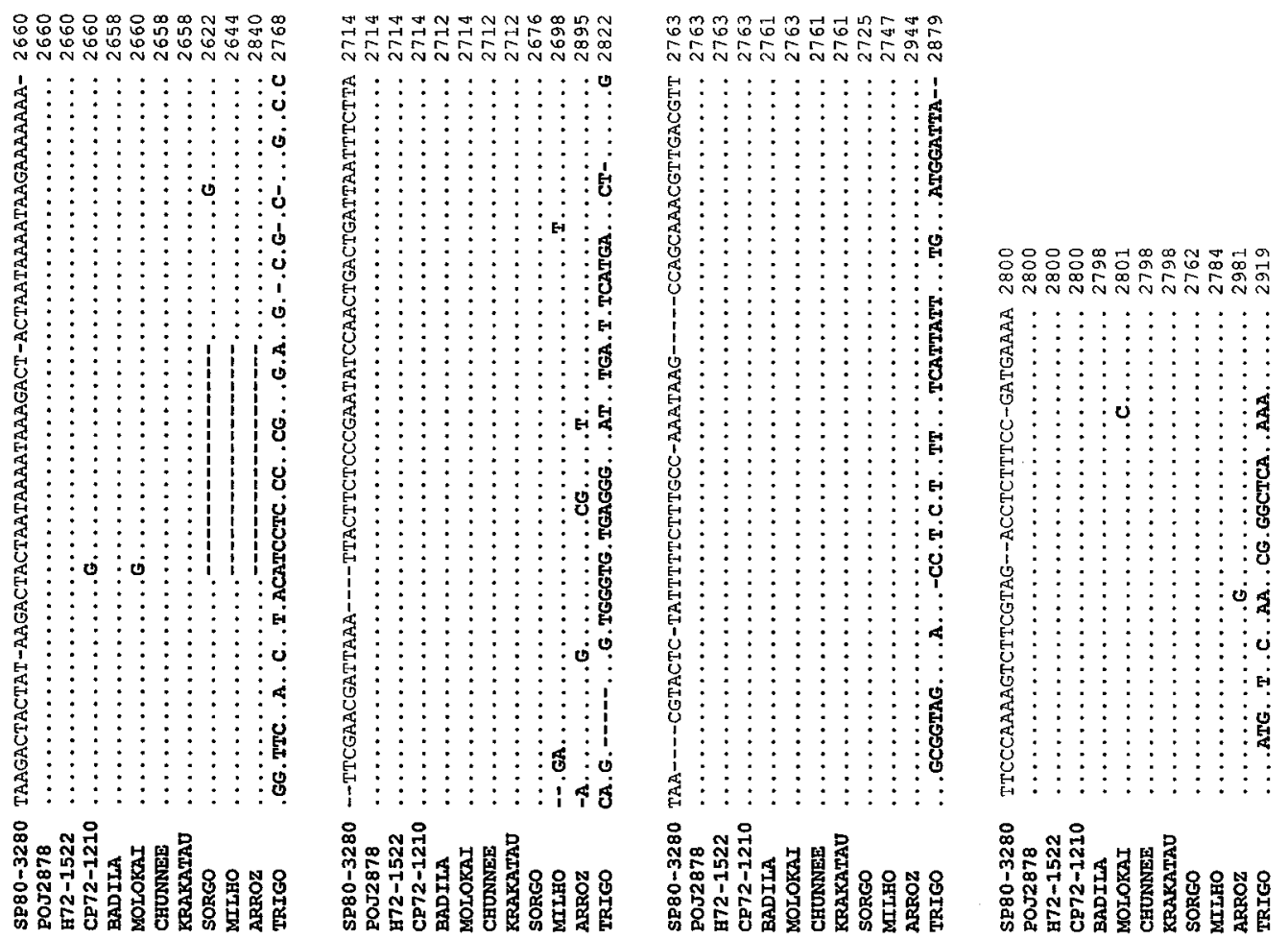


ANEXO C - Alinhamentos da região intergênica entre trnI e trnL. Os códons de iniciação e terminação de cada gene estão marcados em cinza. O nome de cada gene está próximo dos códons de iniciação e terminação. As linhas contínuas que estão ao redor das bases nitrogenadas delimitam cada gene do início ao fim. Os pontos alinhados representam as mesmas bases nitrogenadas do híbrido SP80-3280. Os traços representam os gaps (deleções de bases nitrogenadas). As mutações são apresentadas pelas bases nitrogenadas em negrito que diferem do híbrido SP80-3280. 

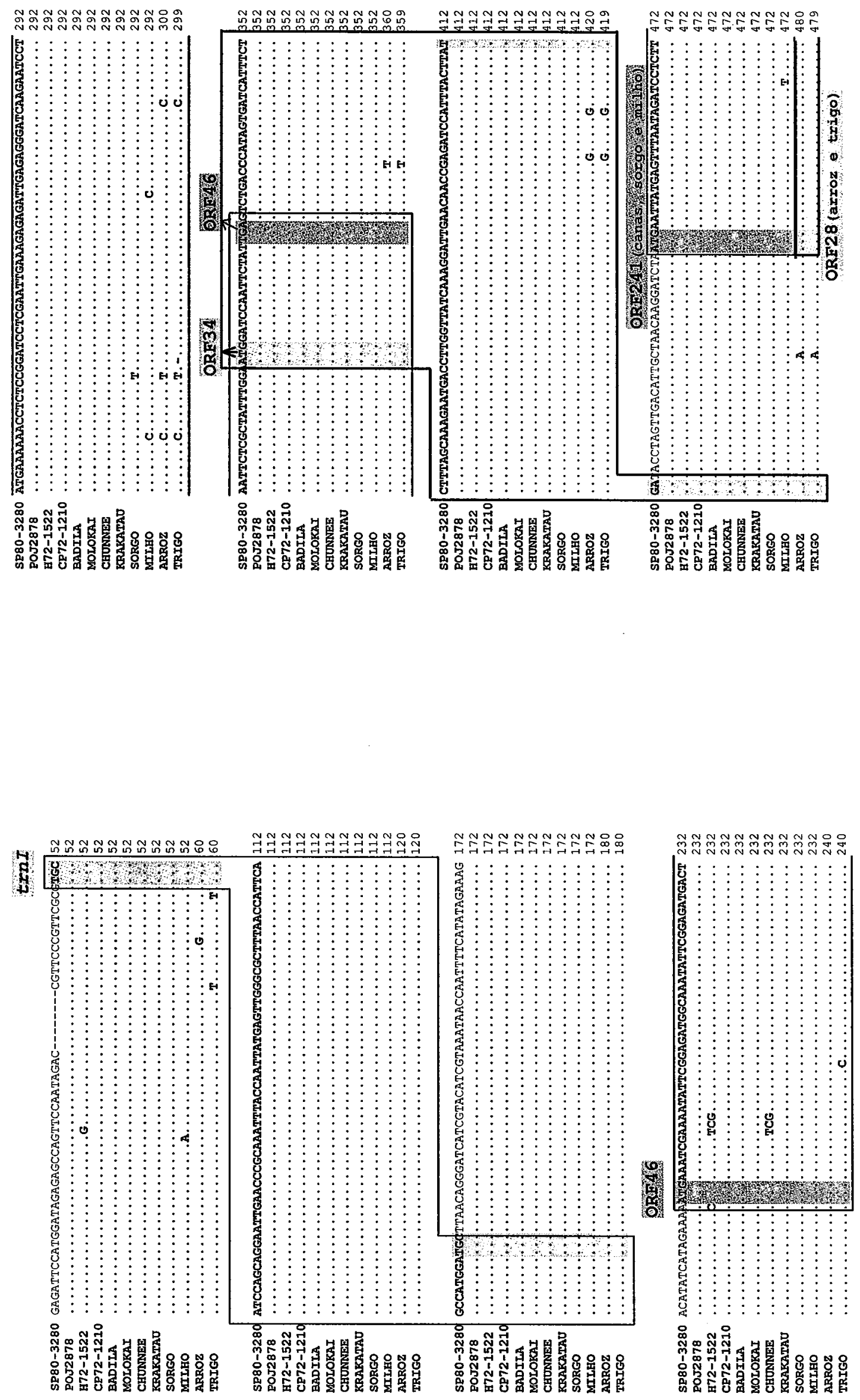

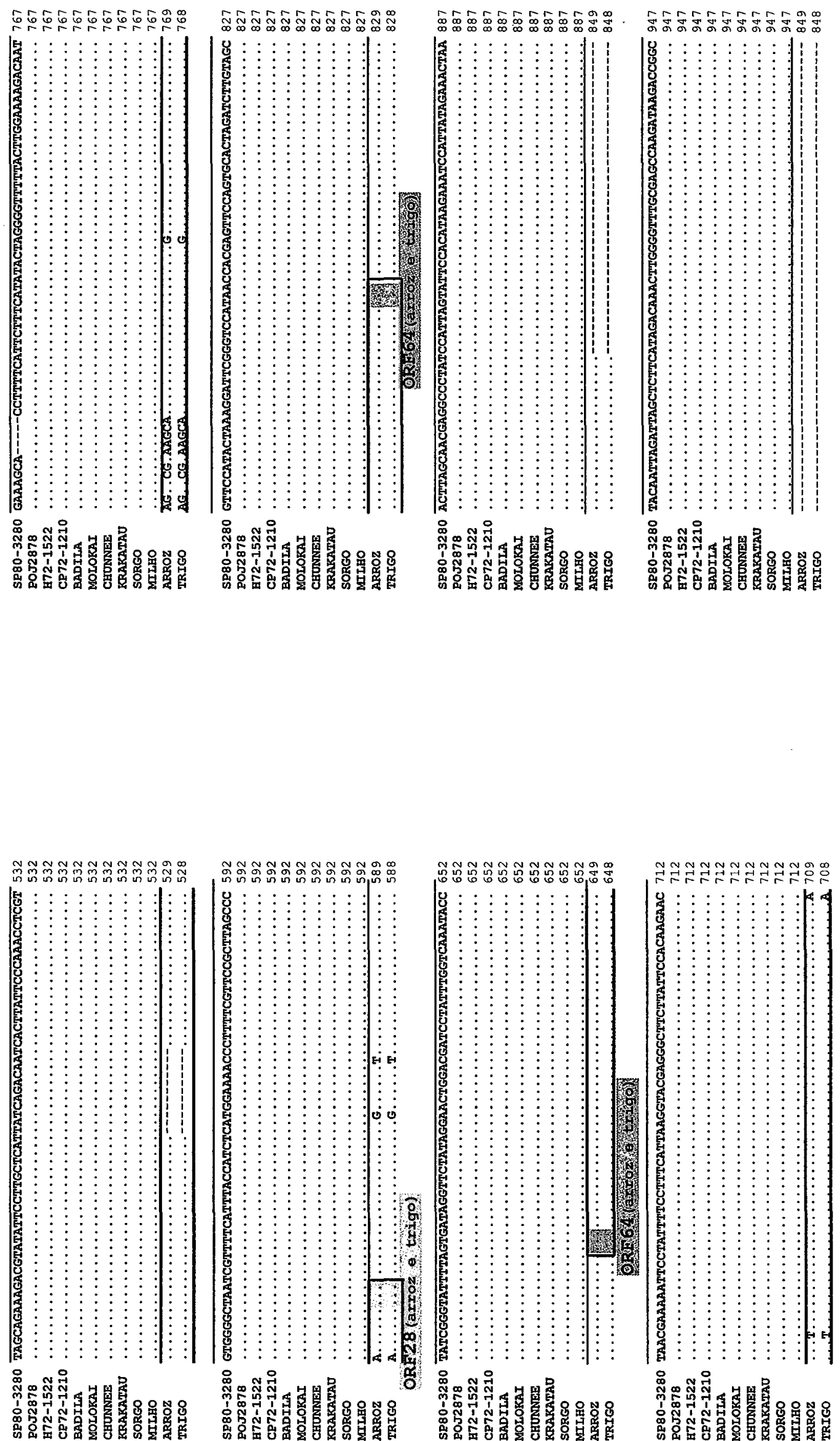


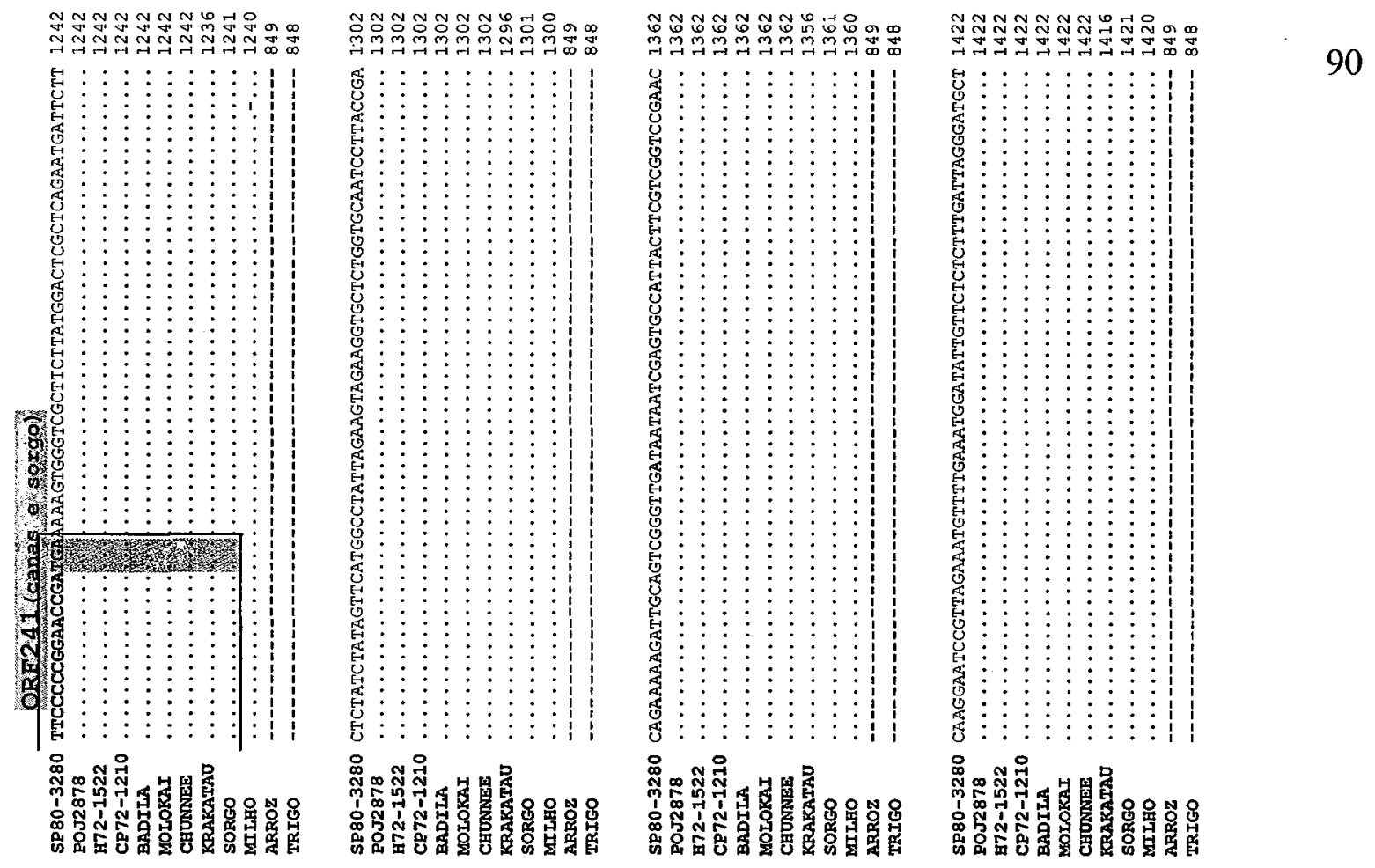

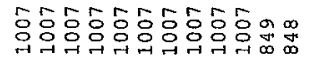
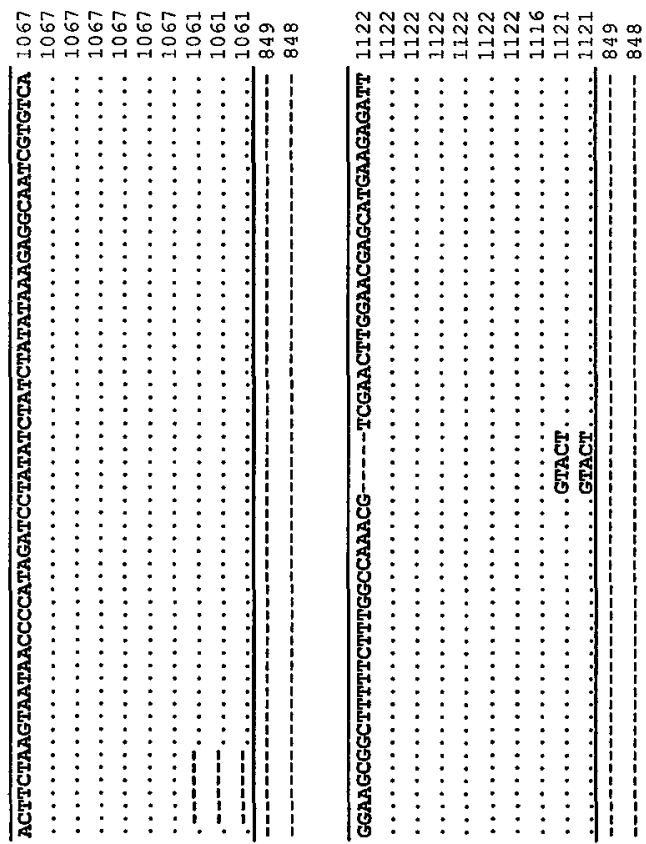

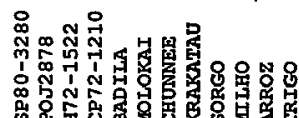
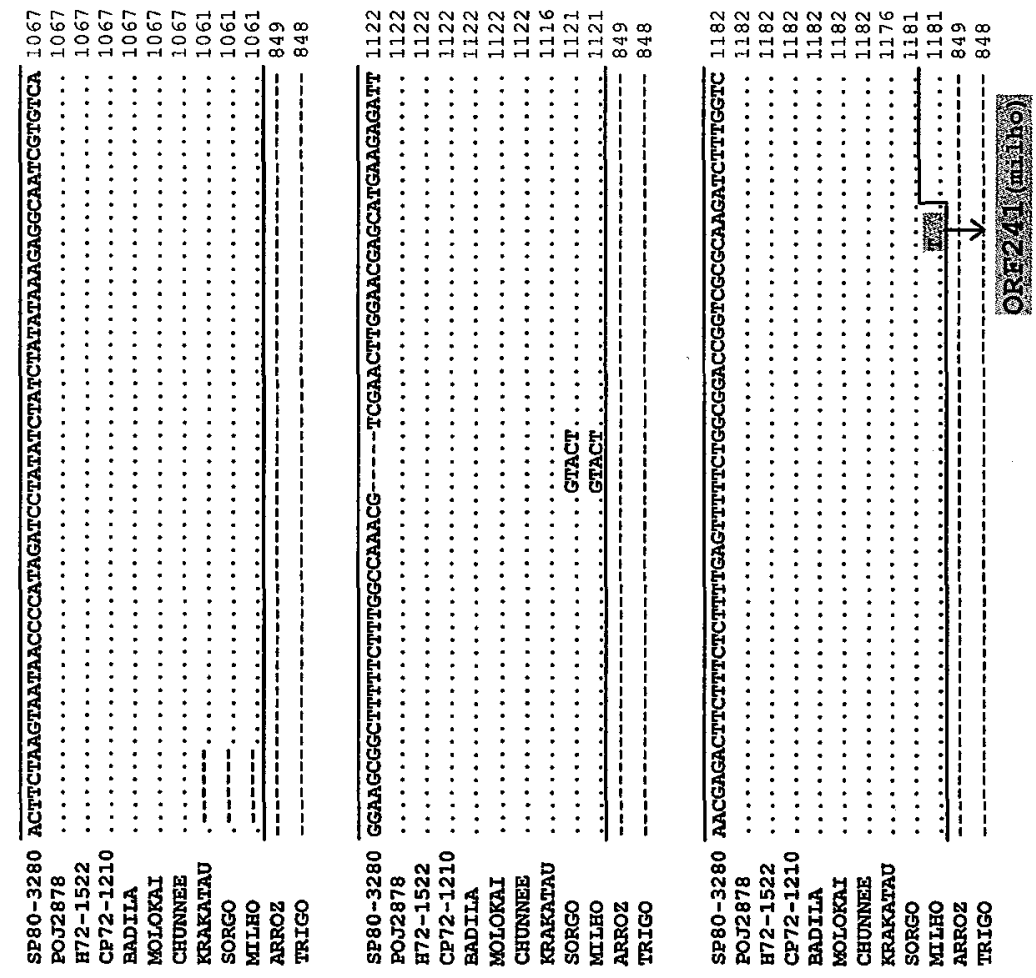

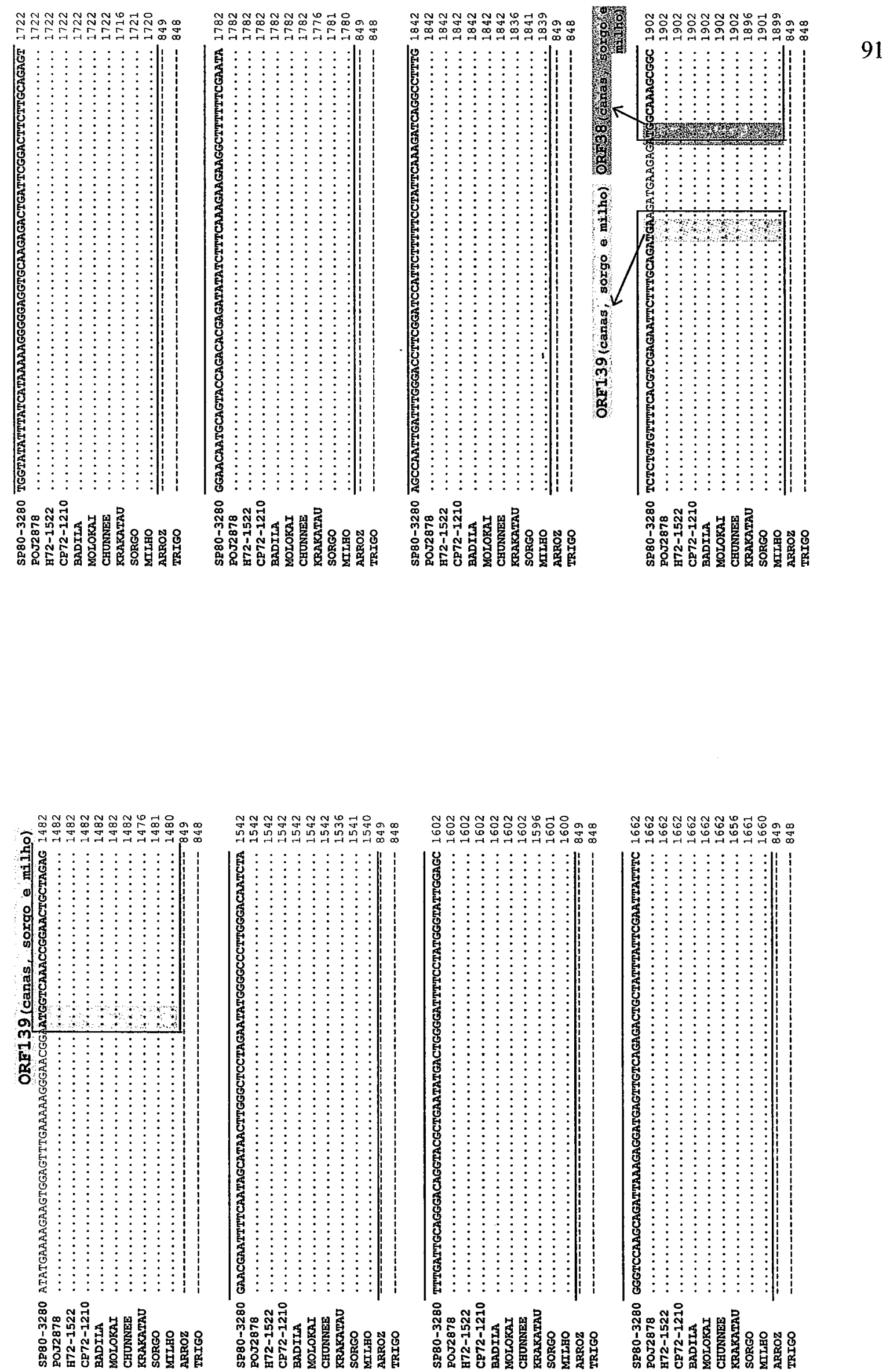

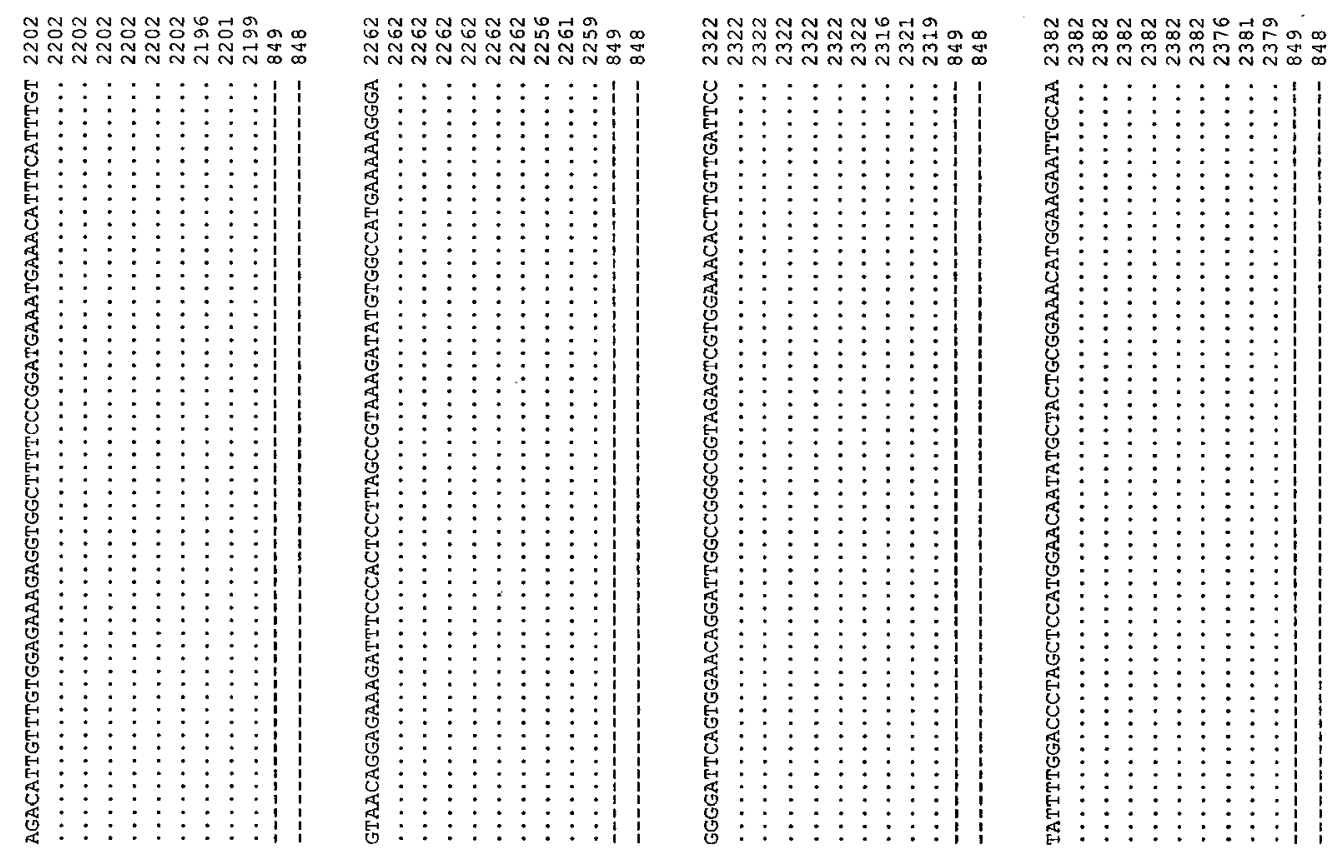

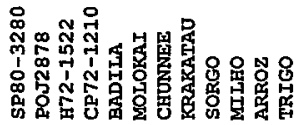

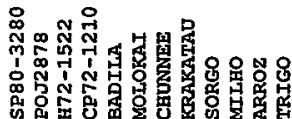

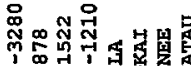

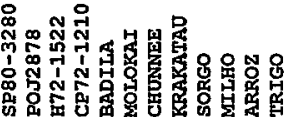
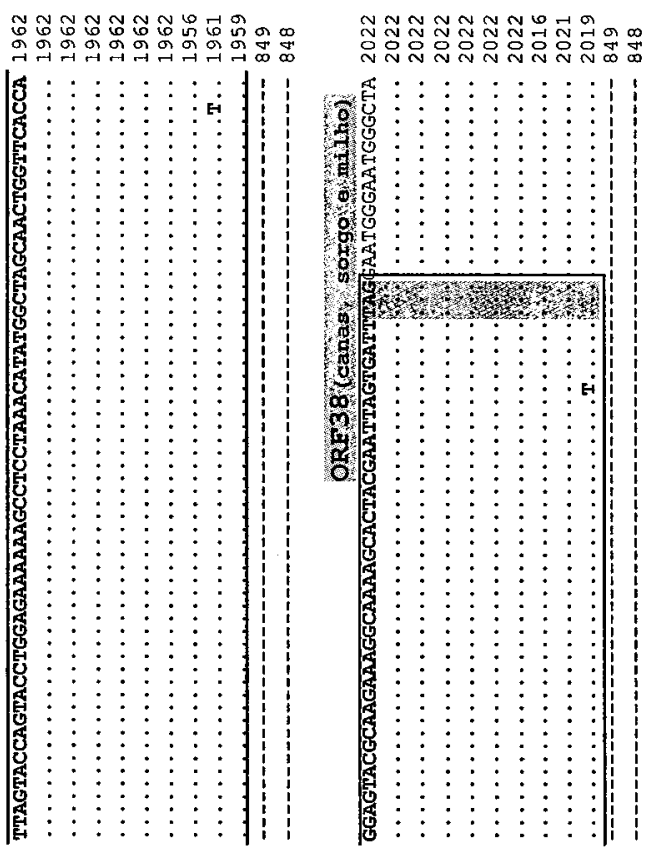

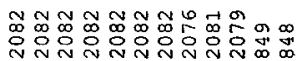

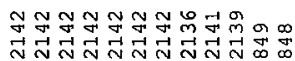
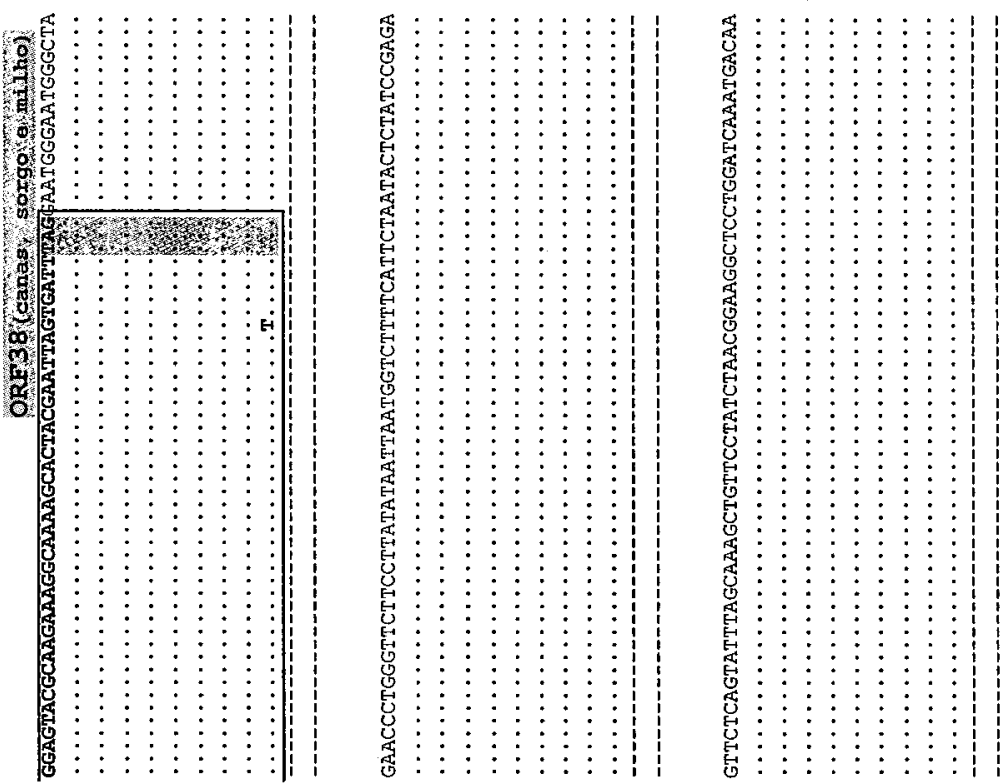

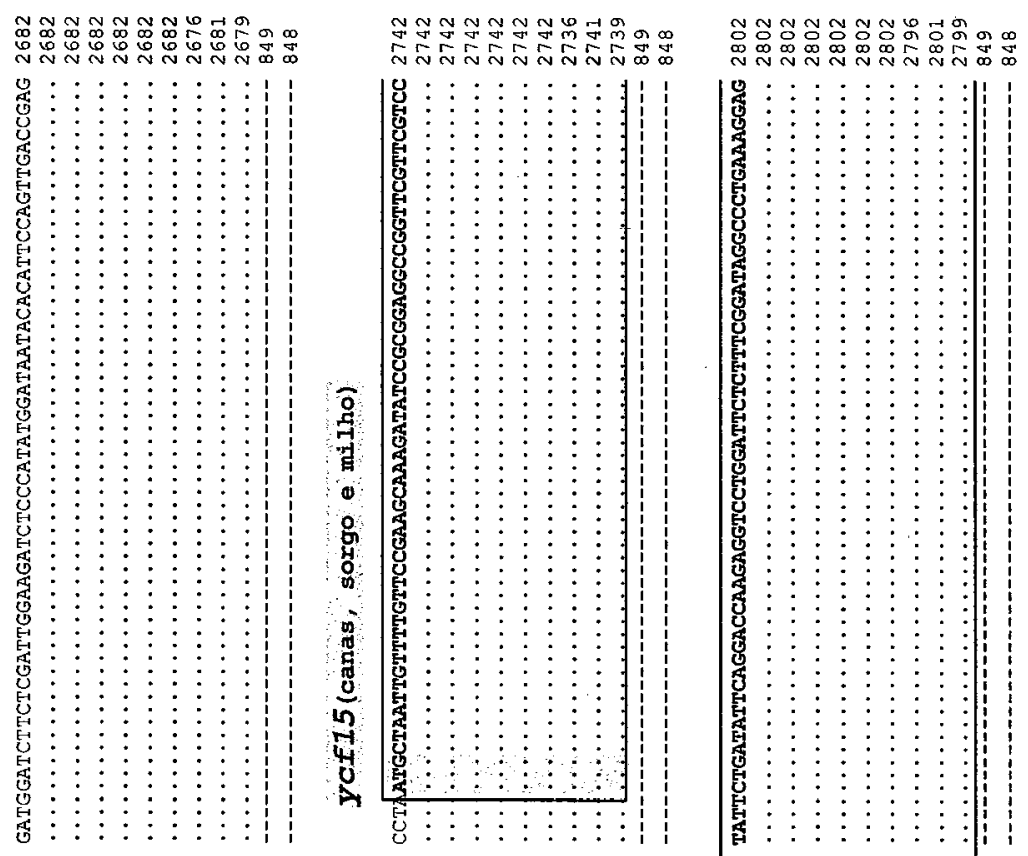

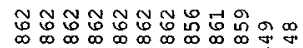
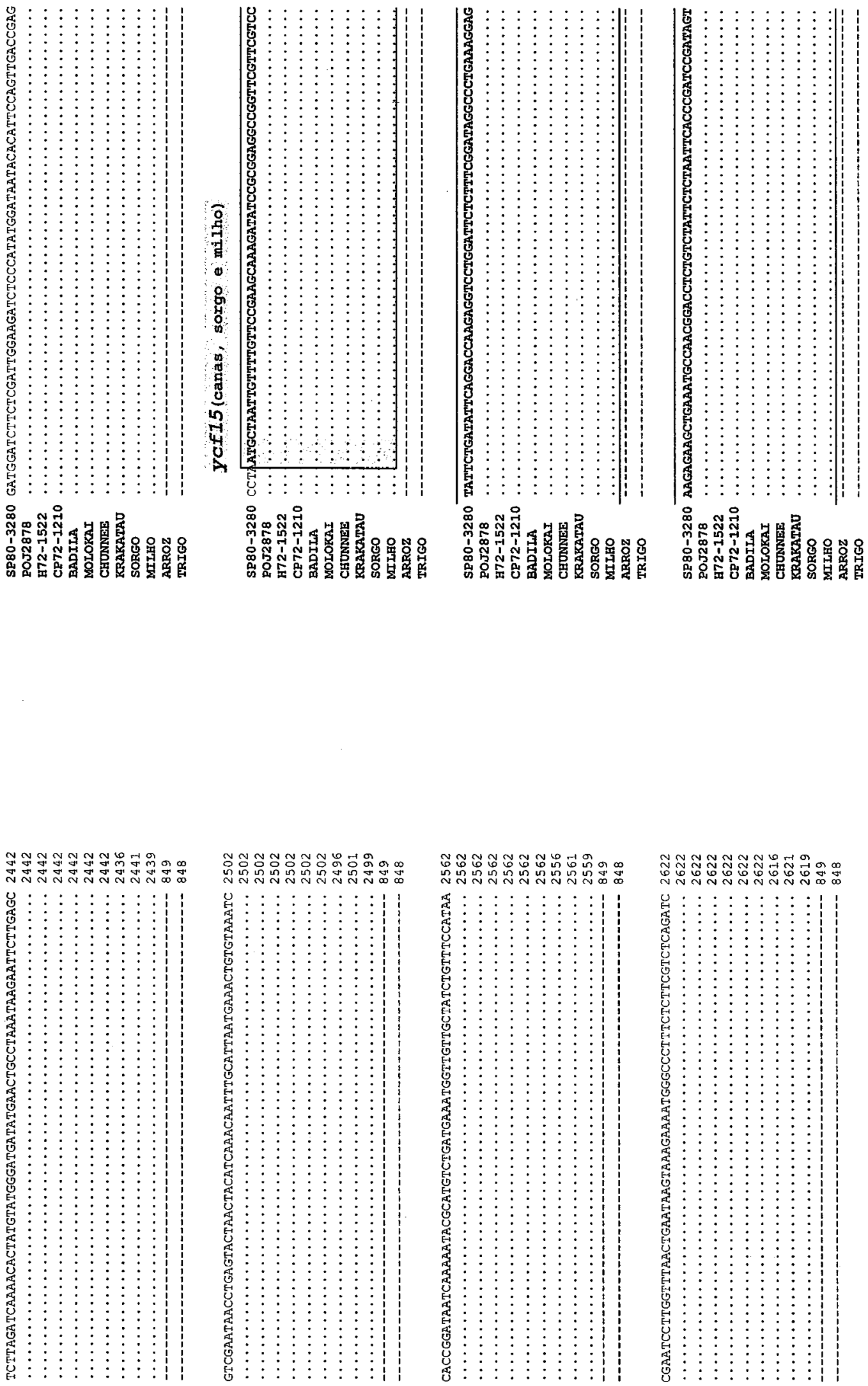

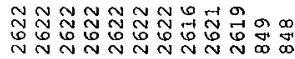

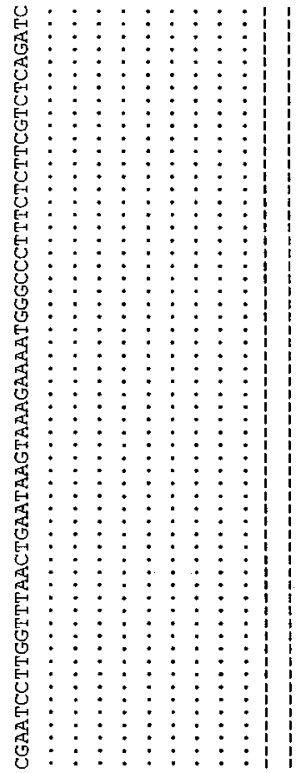



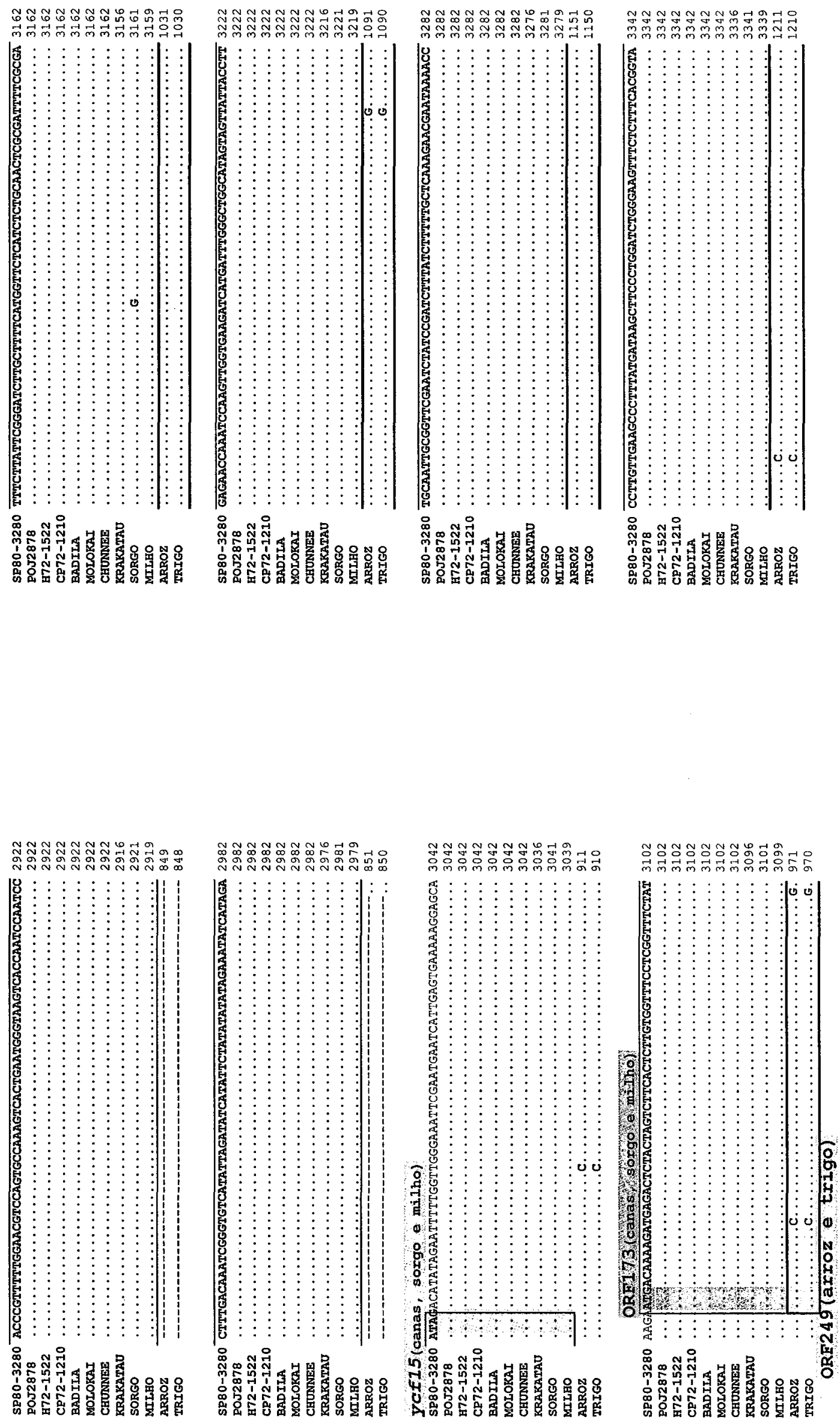

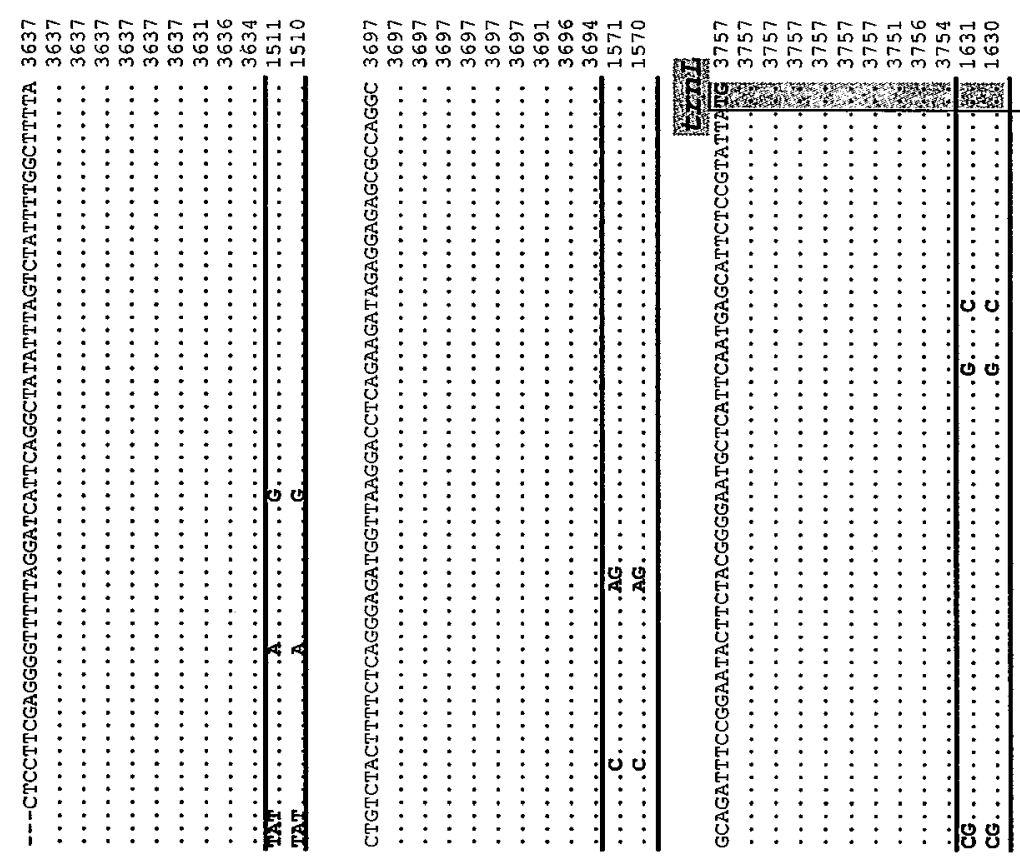

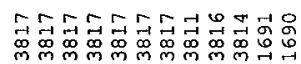

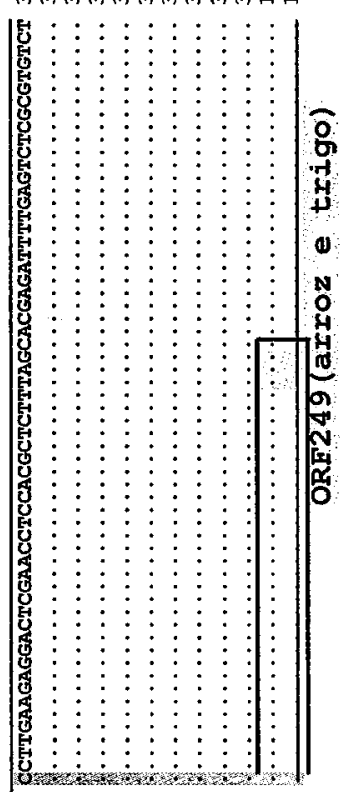

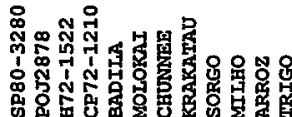

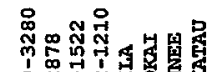

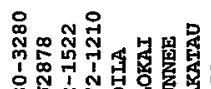

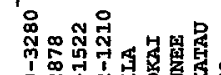
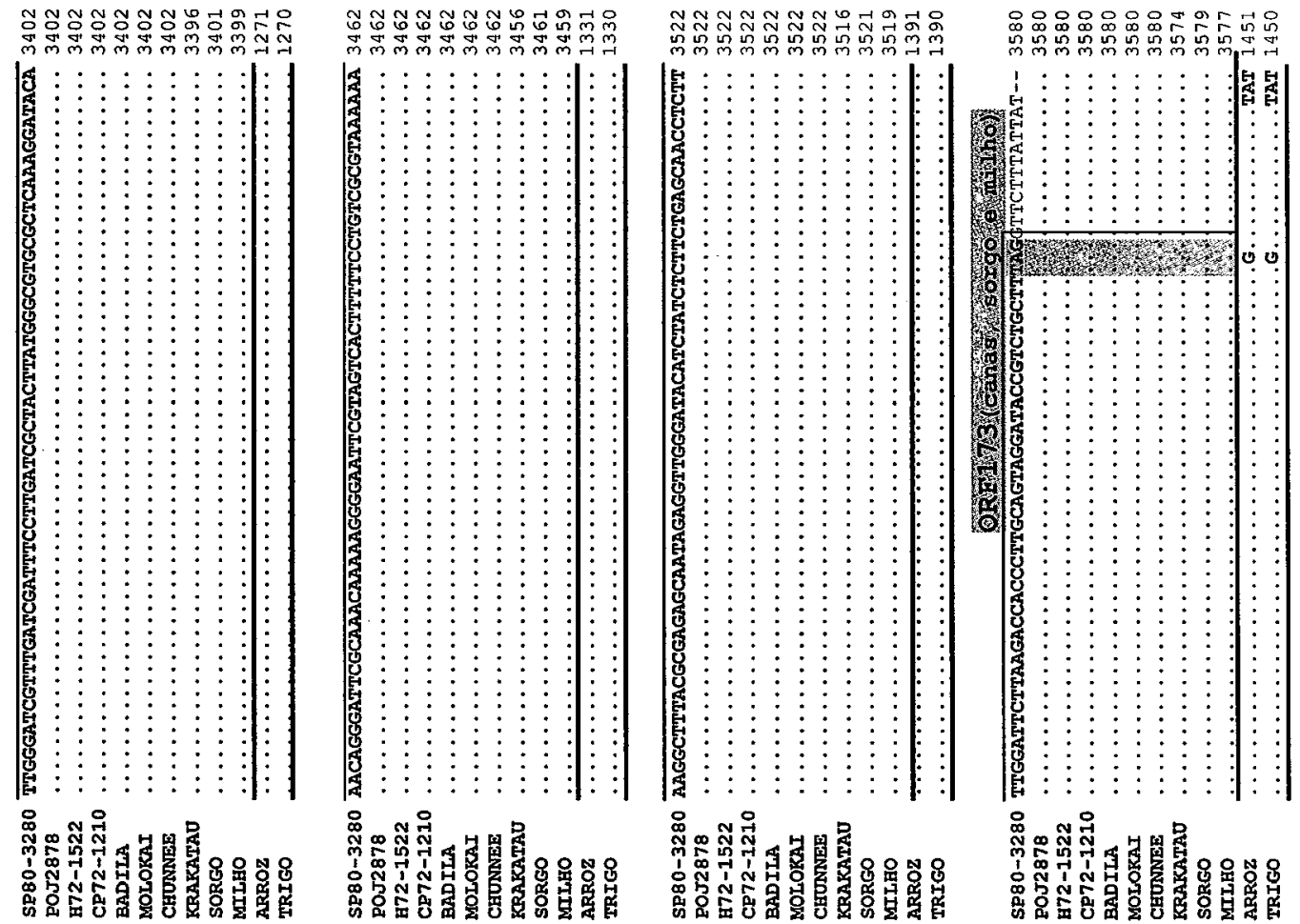


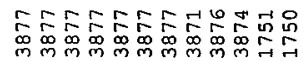

U : : : :

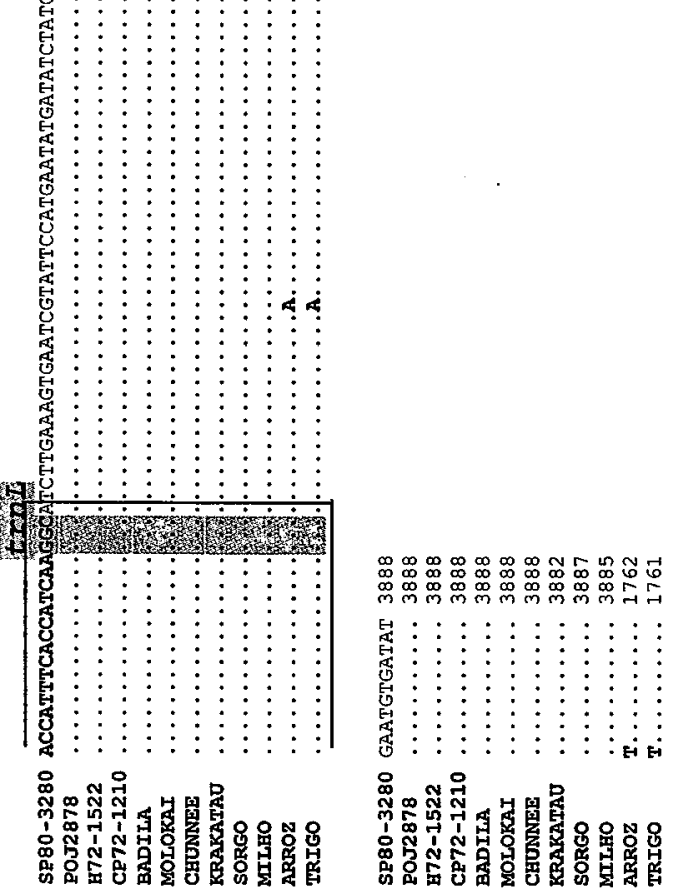


ANEXO D - Alinhamentos da região intergênica entre $r b c L$ e petA. Os códons de iniciação e terminação de cada gene estão marcados em cinza. O nome de cada gene está próximo dos códons de iniciação e terminação. As linhas contínuas que estão ao redor das bases nitrogenadas delimitam cada gene do início ao fim. Os pontos alinhados representam as mesmas bases nitrogenadas do híbrido SP80-3280. Os traços representam os gaps (deleções de bases nitrogenadas). As mutações são apresentadas pelas bases nitrogenadas em negrito que diferem do híbrido SP80-3280. 

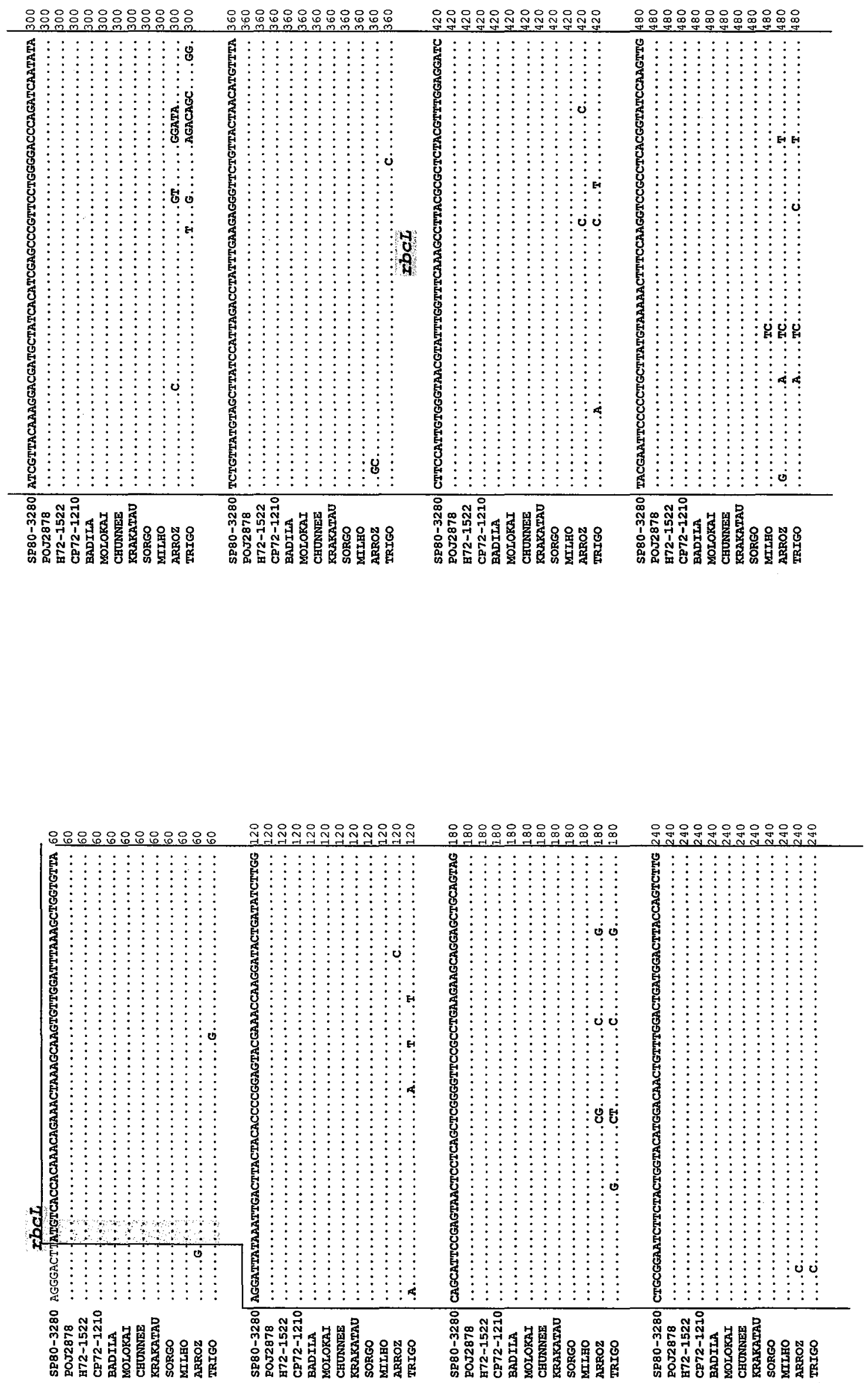


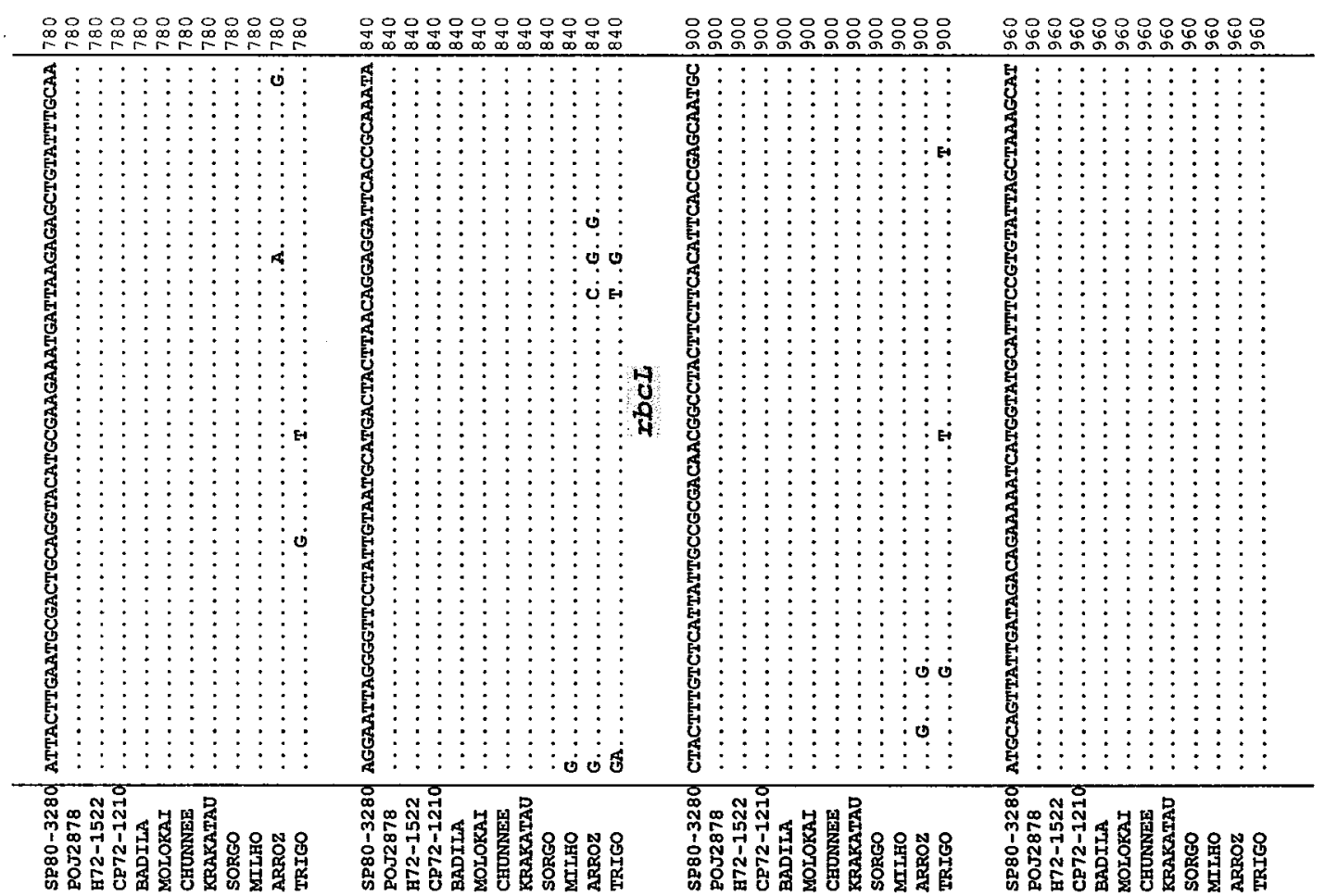

99

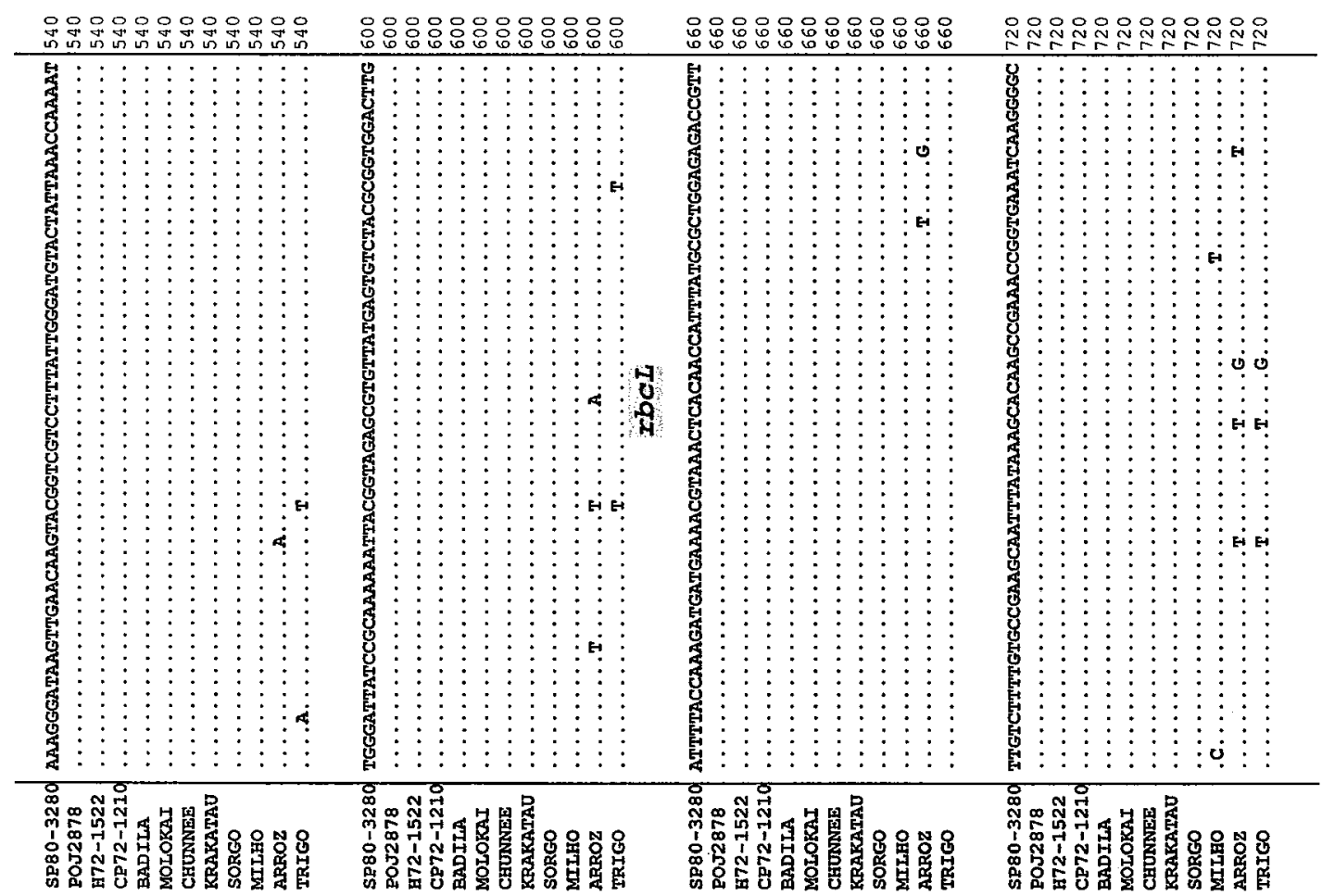



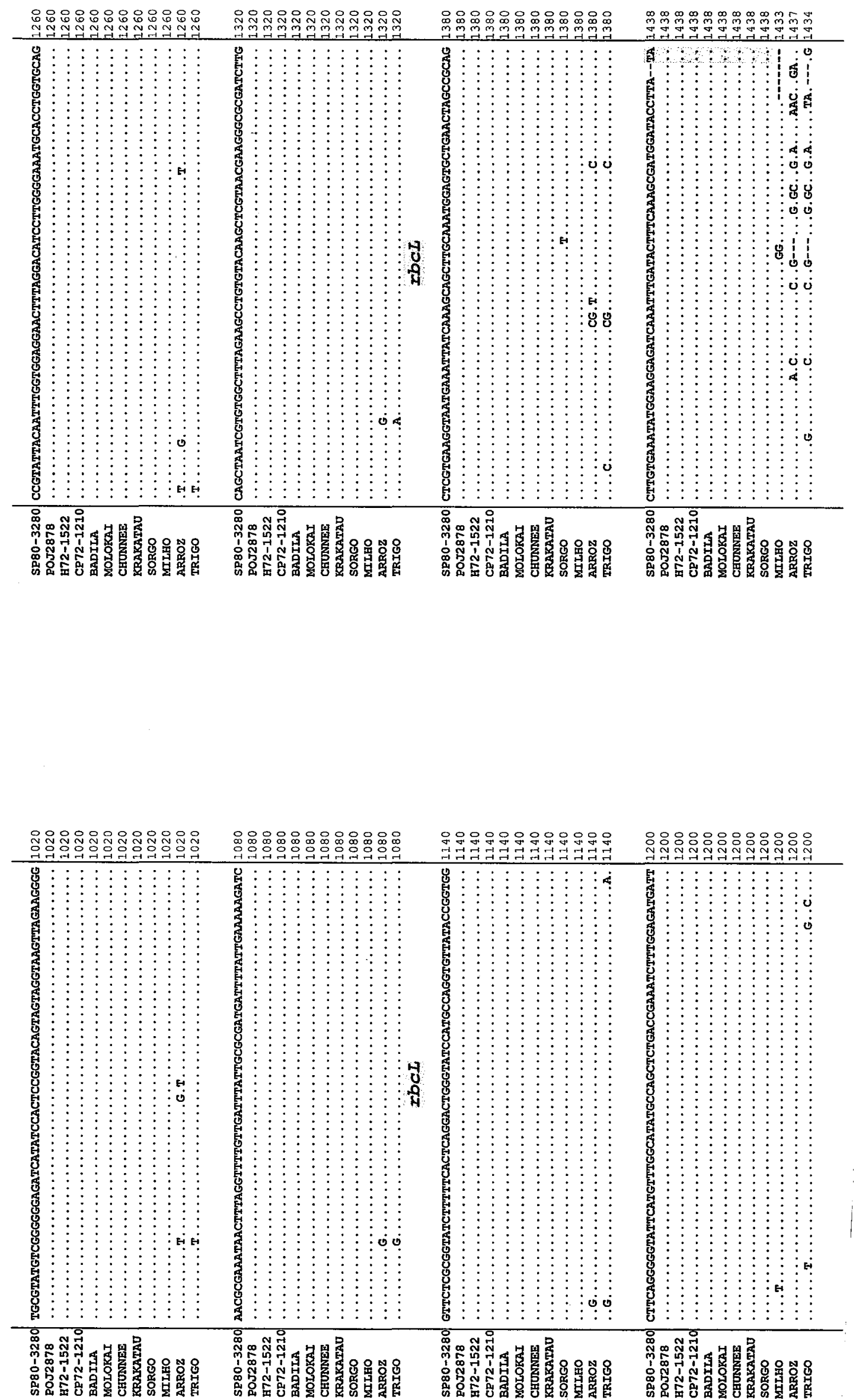


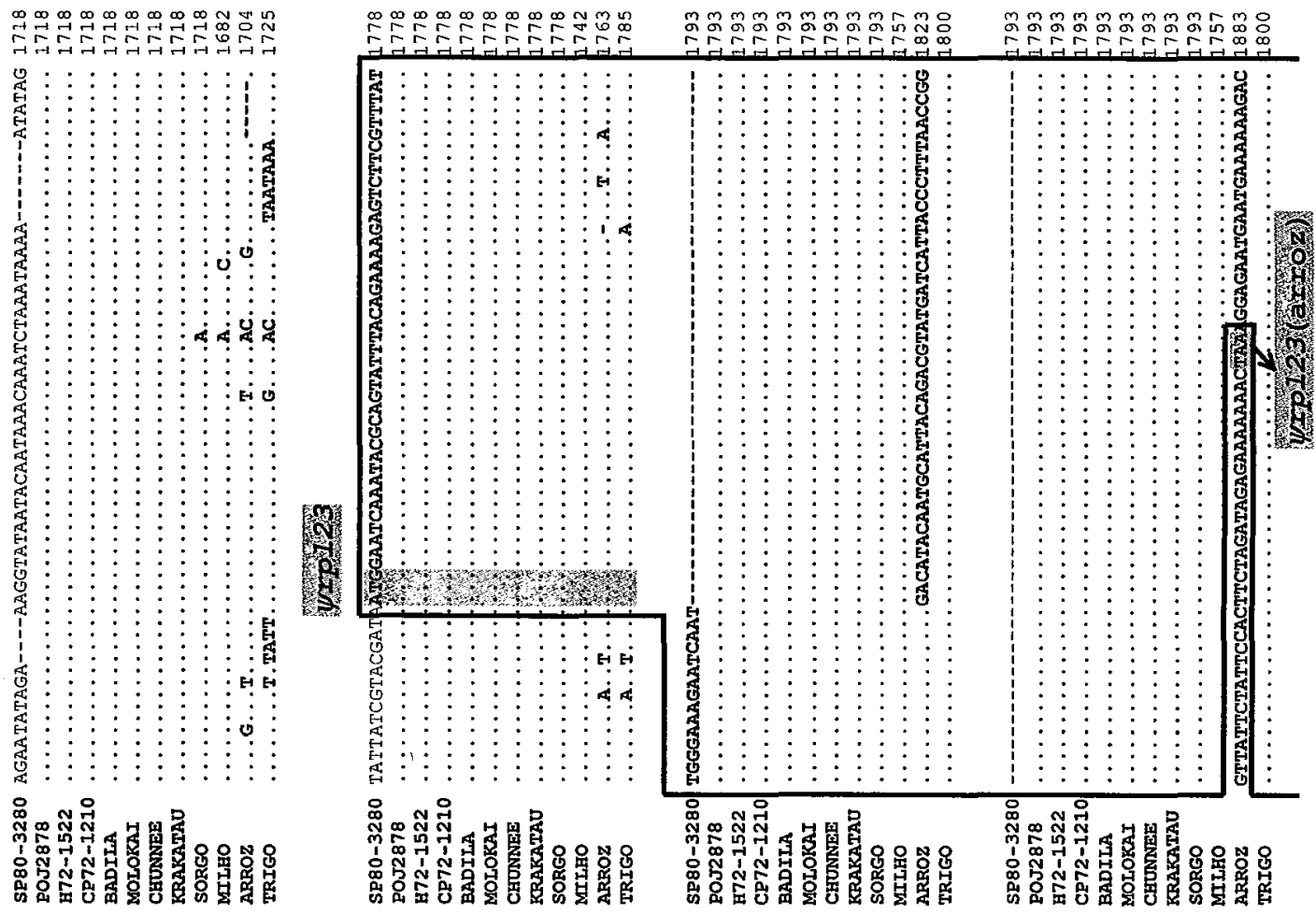

101

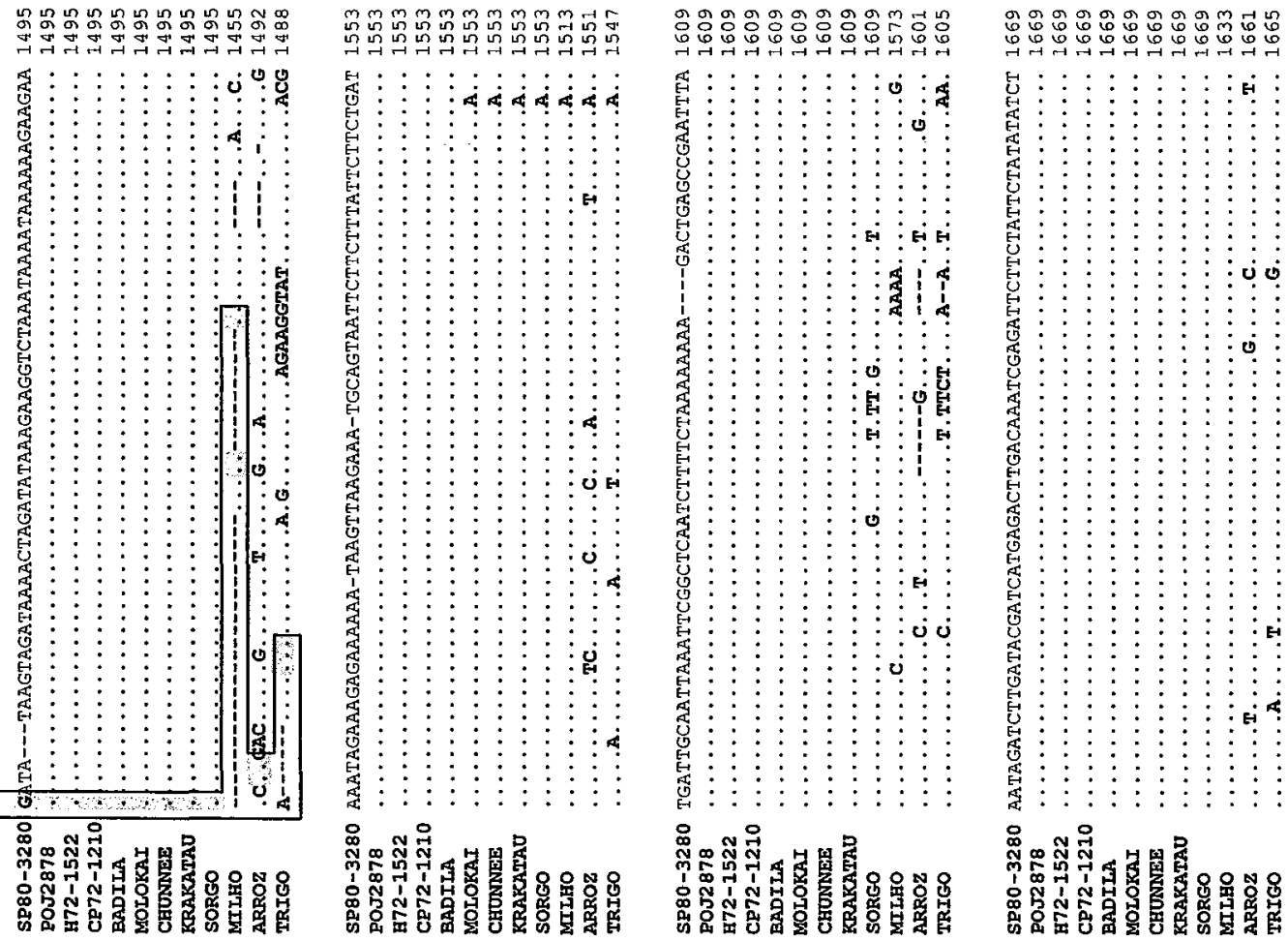




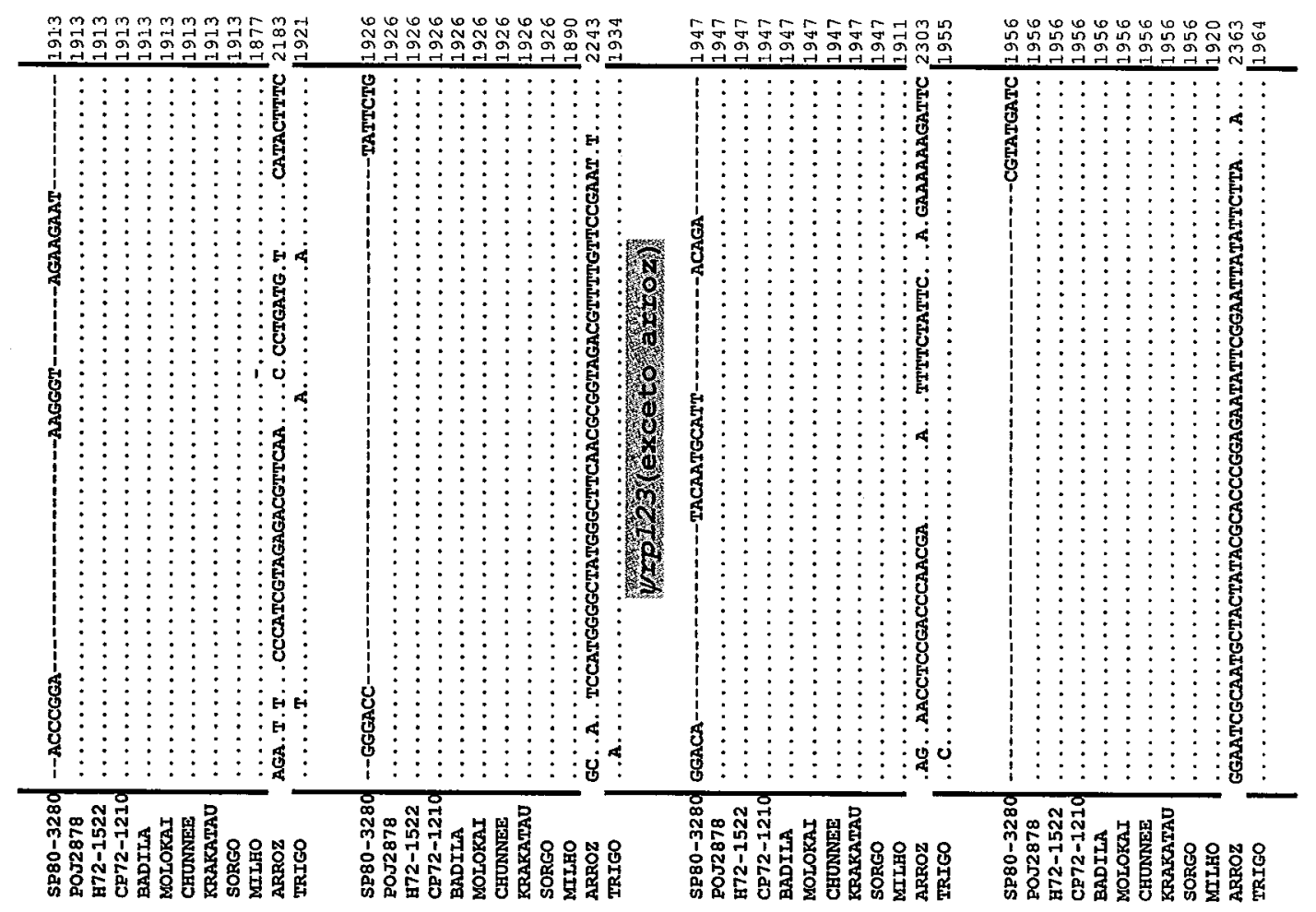

102

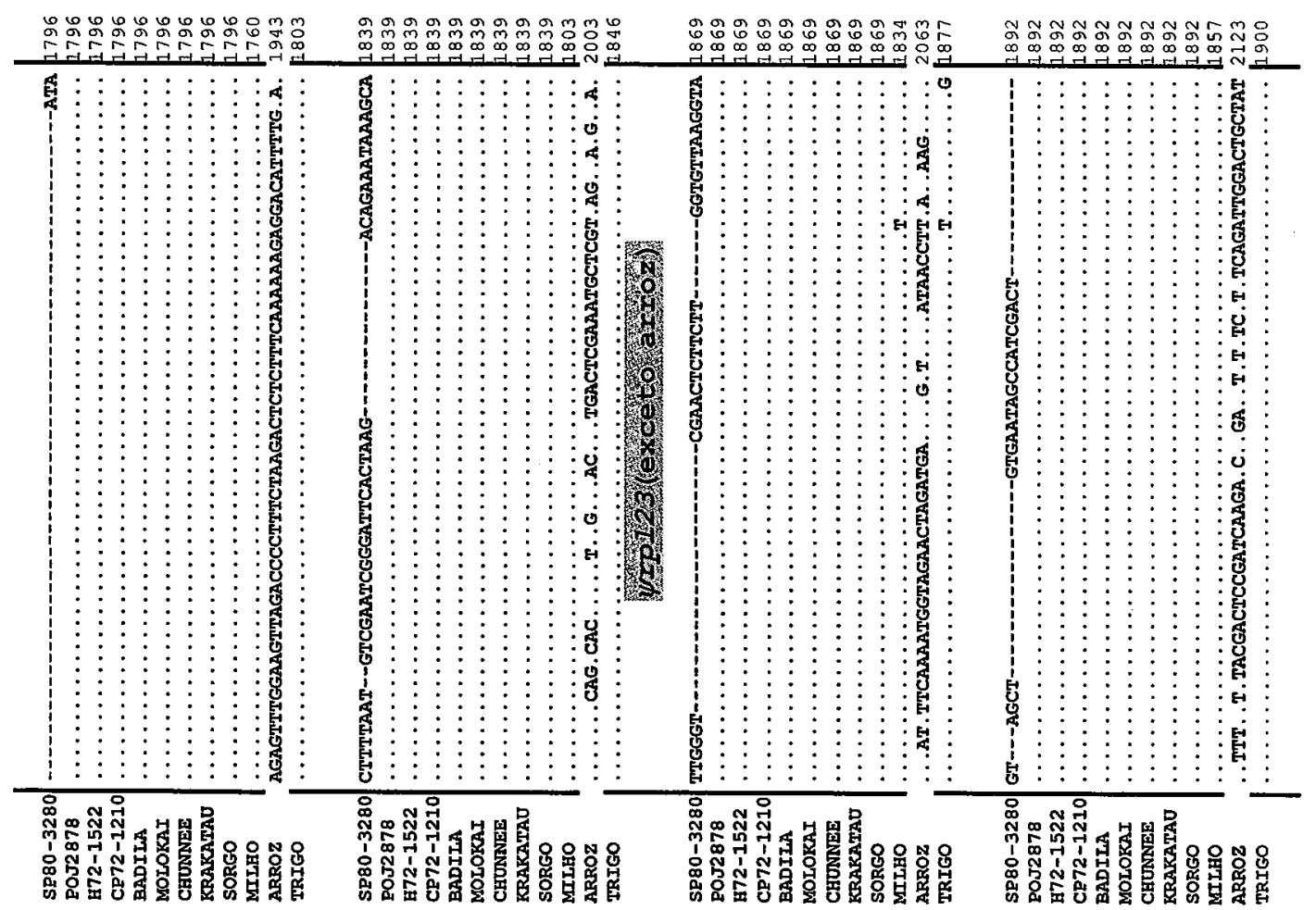



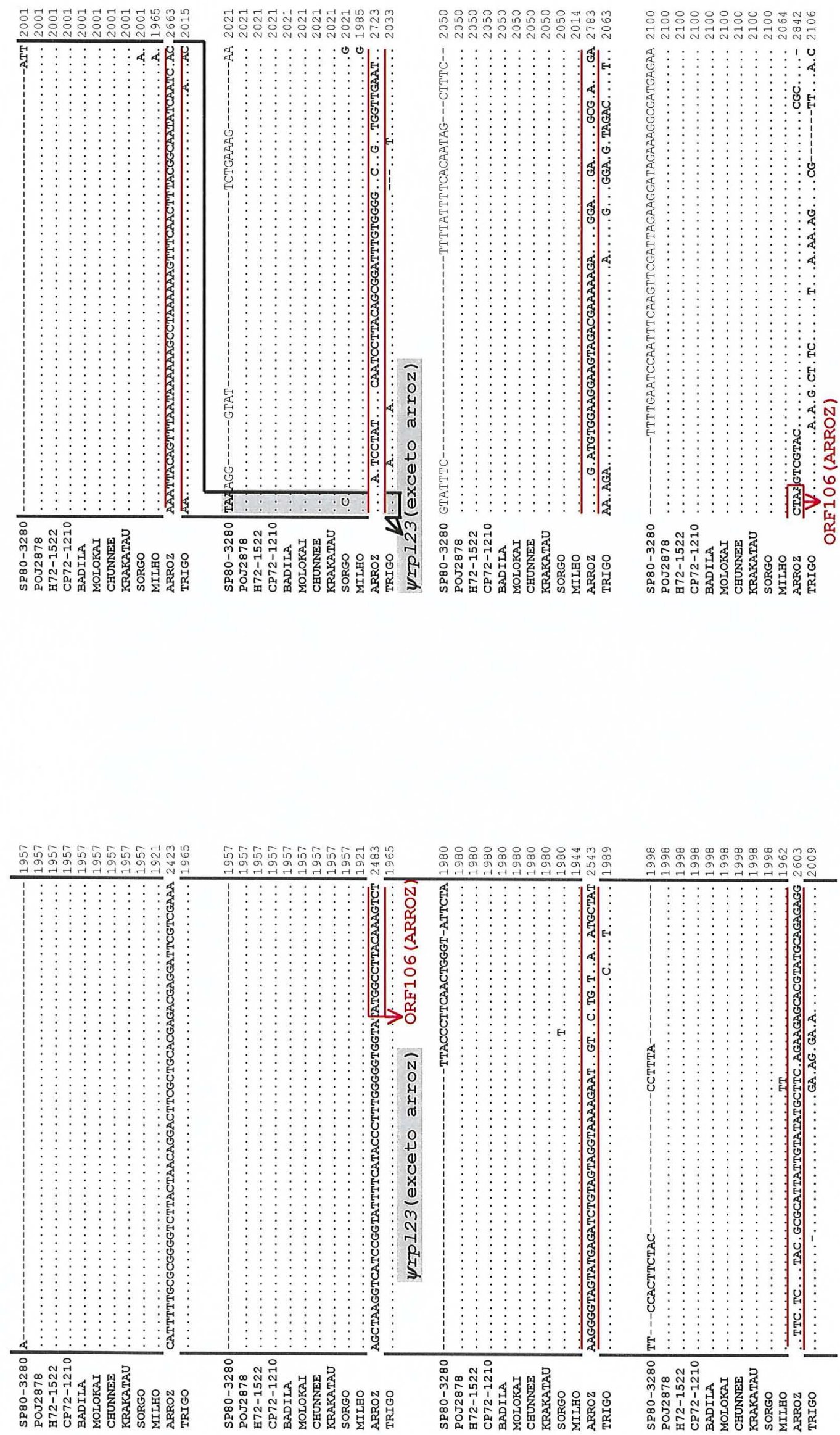

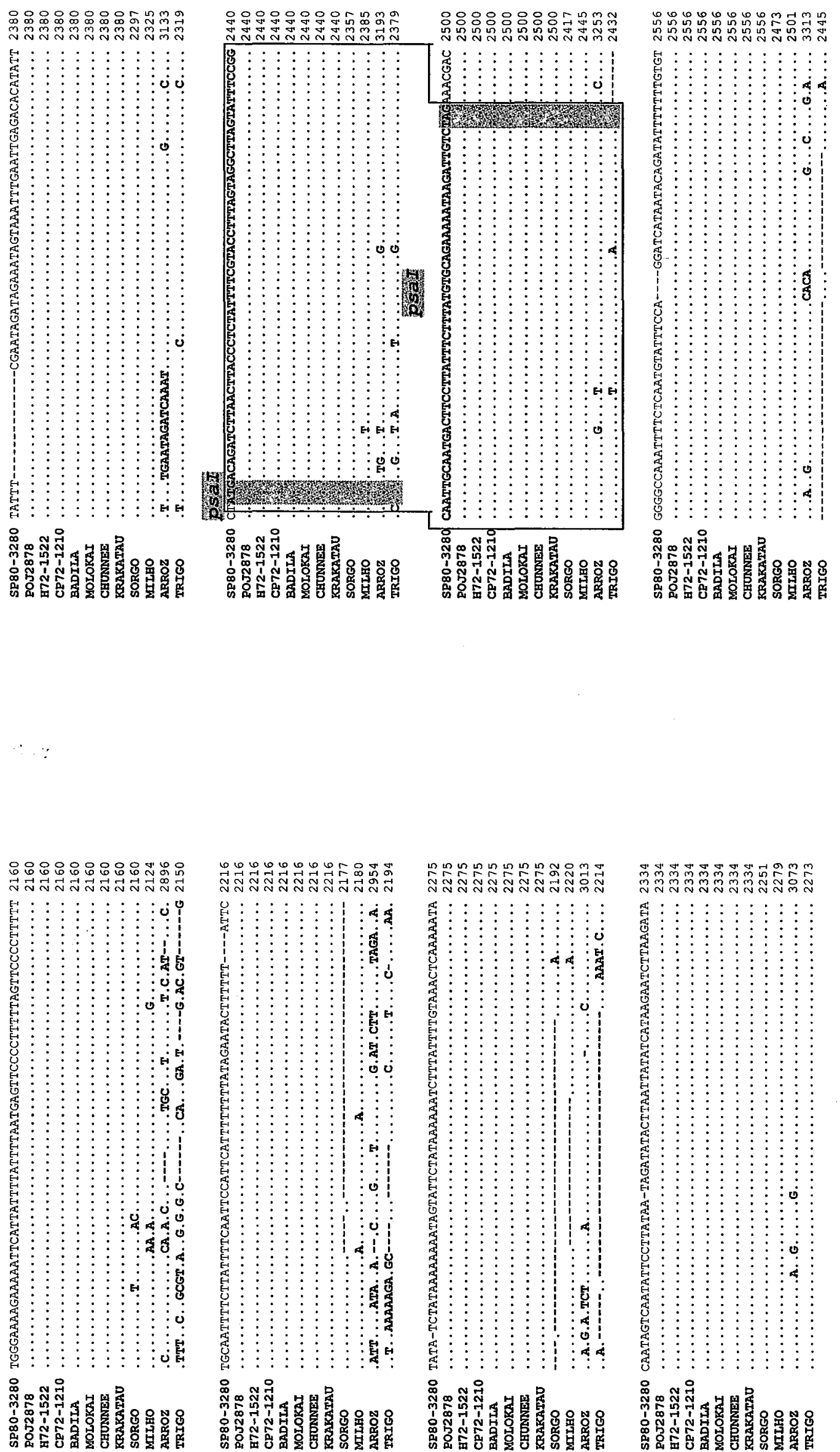

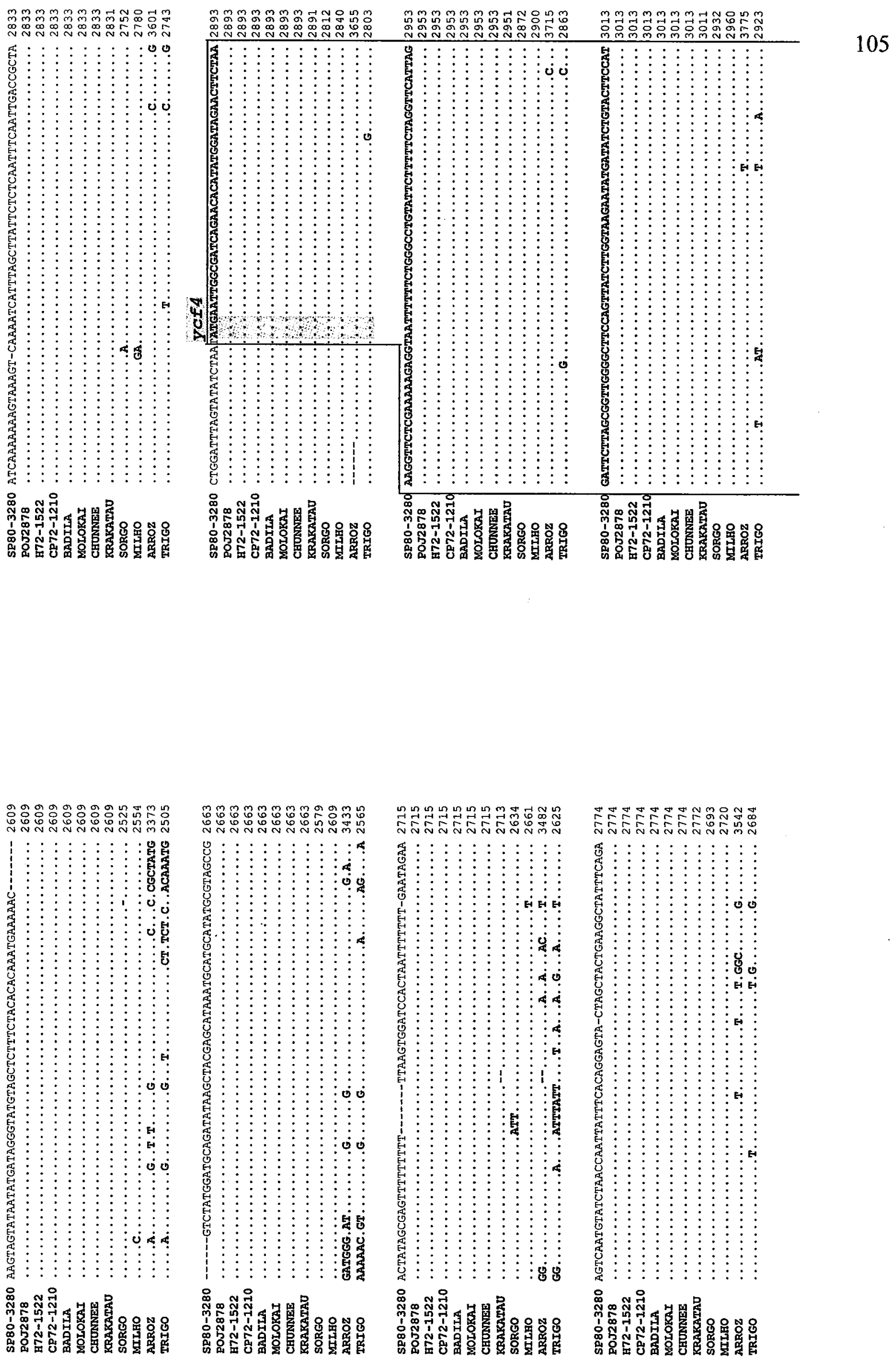

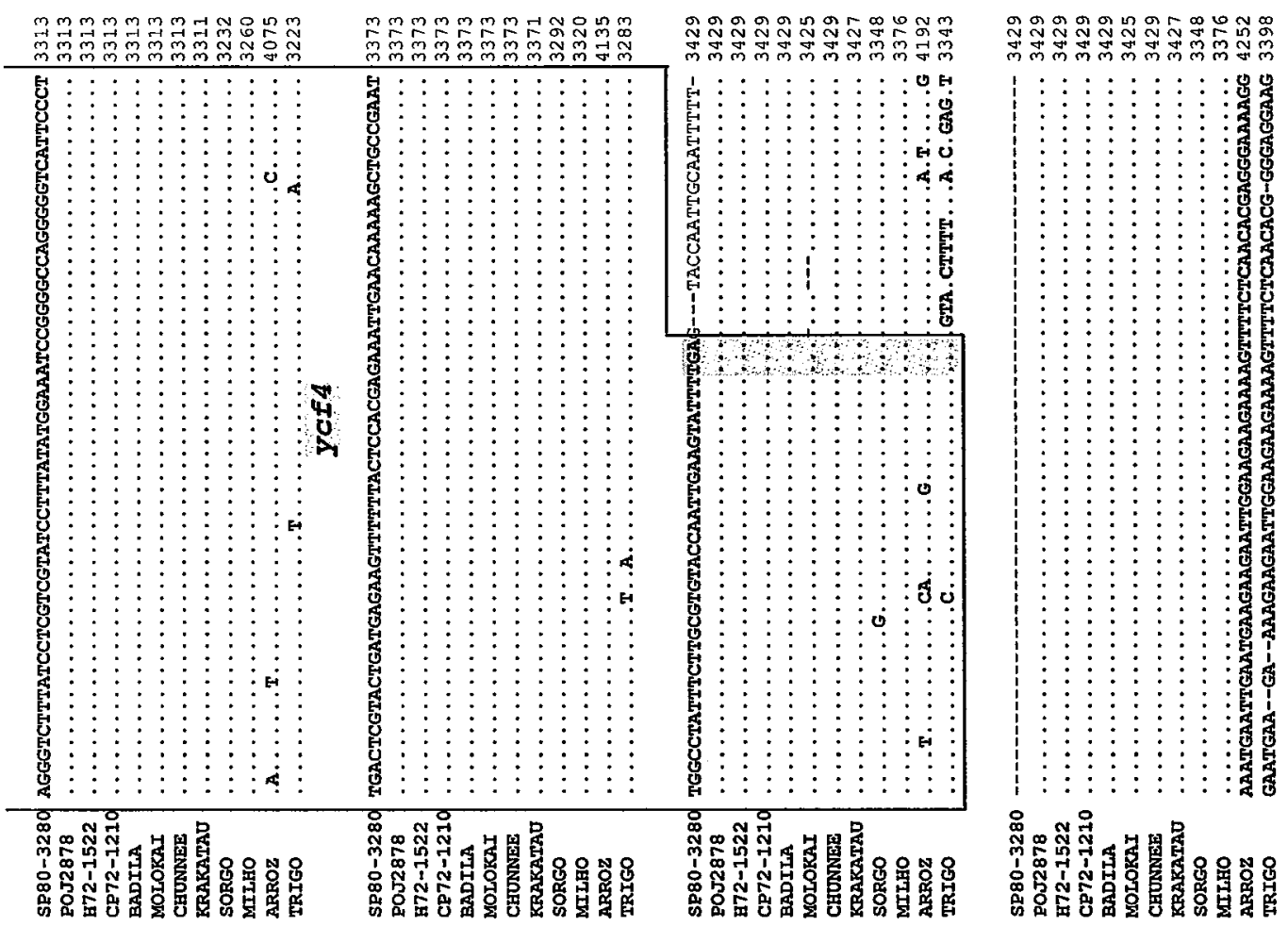

106

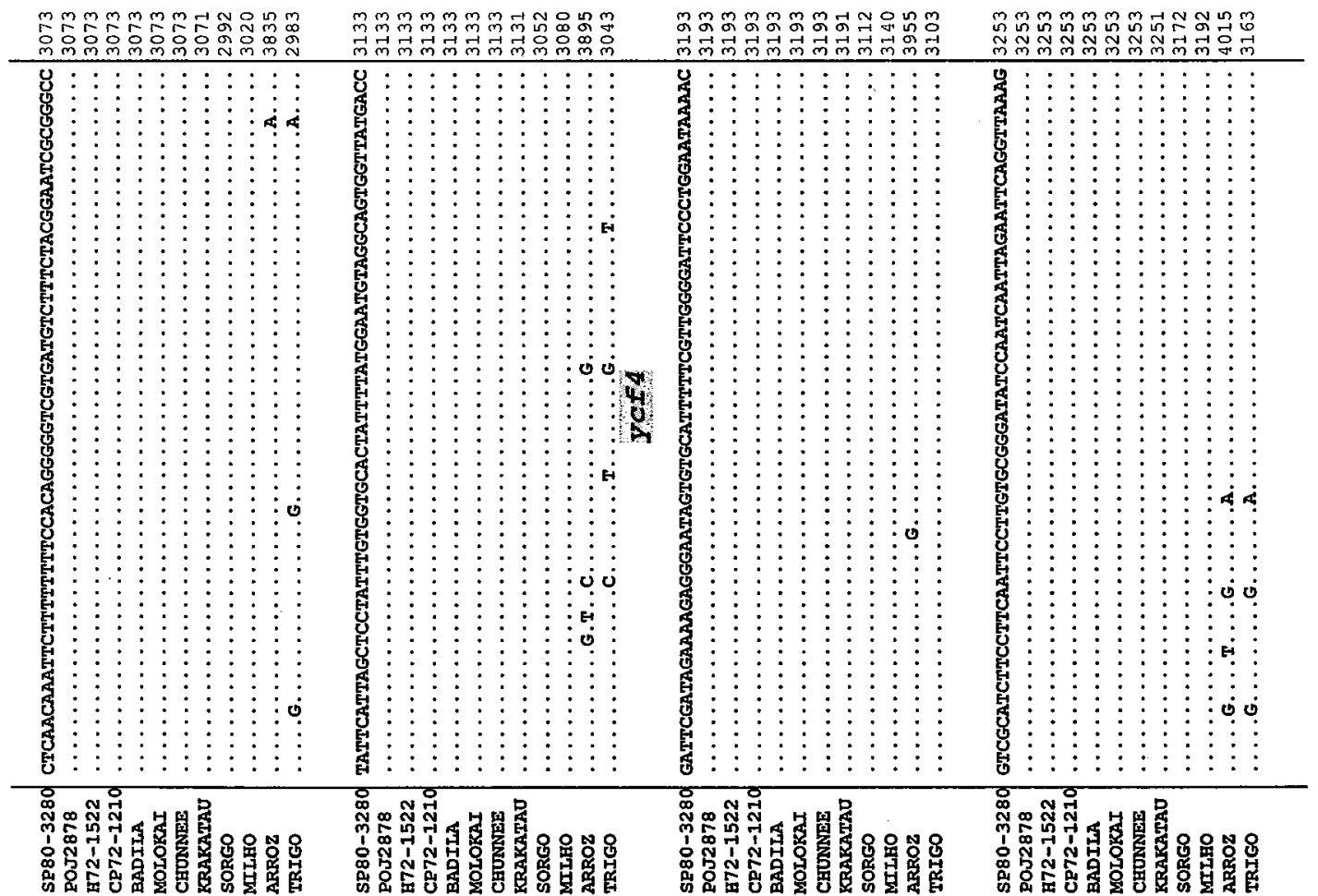



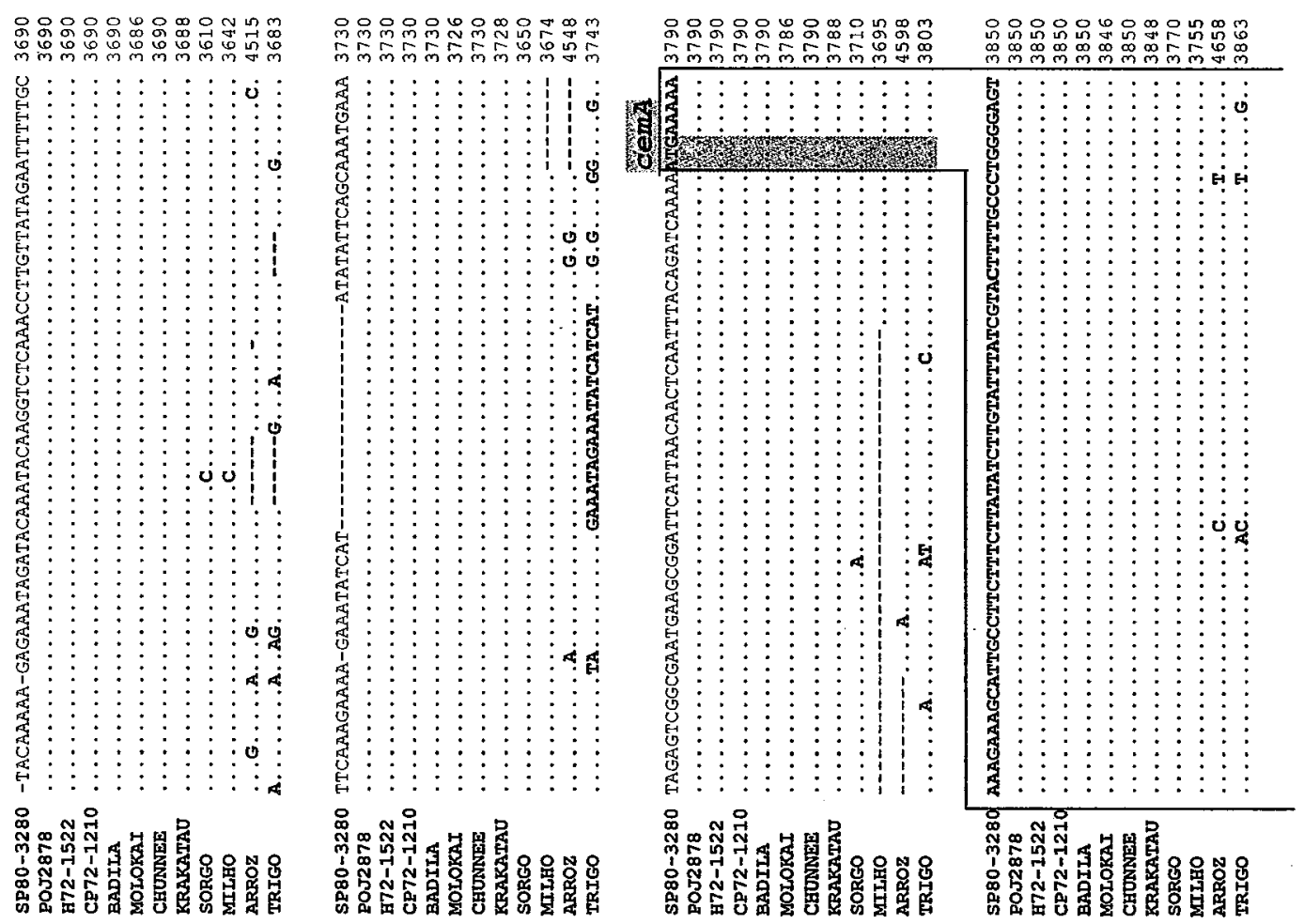

107

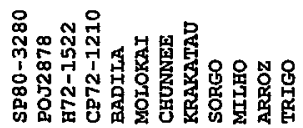
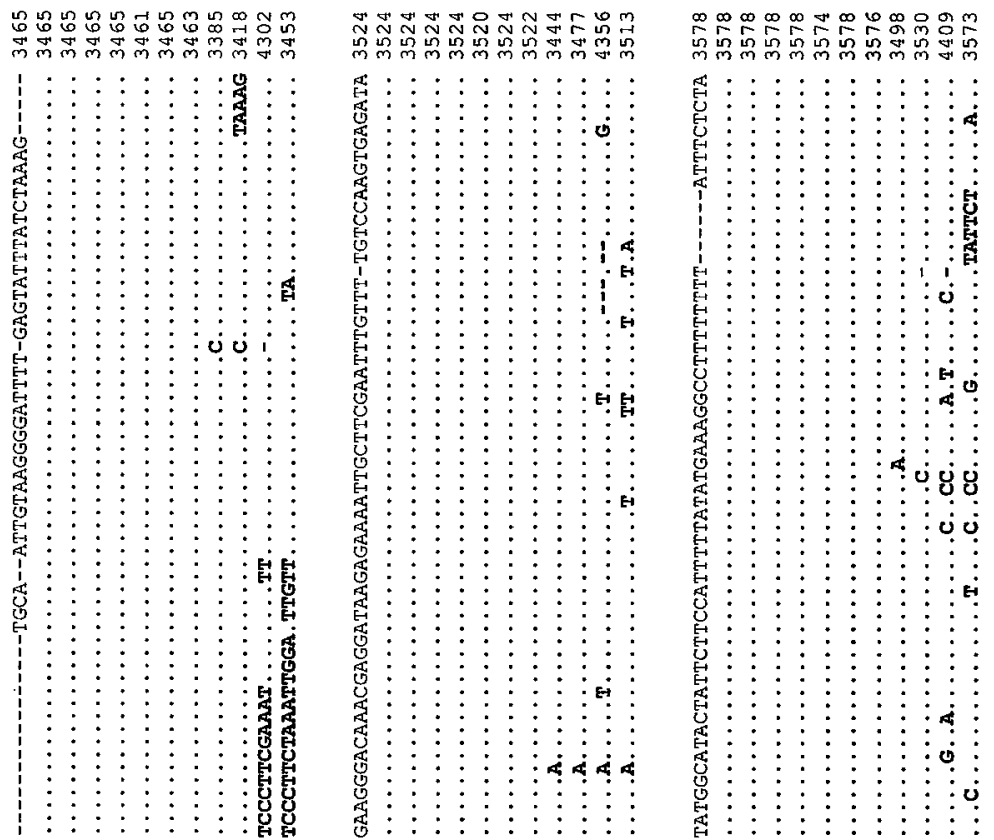

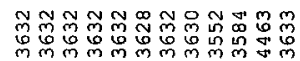

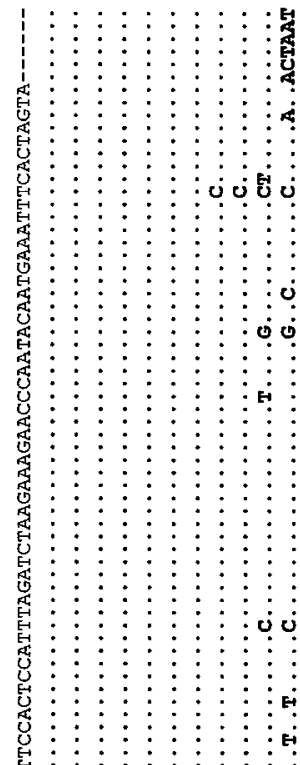



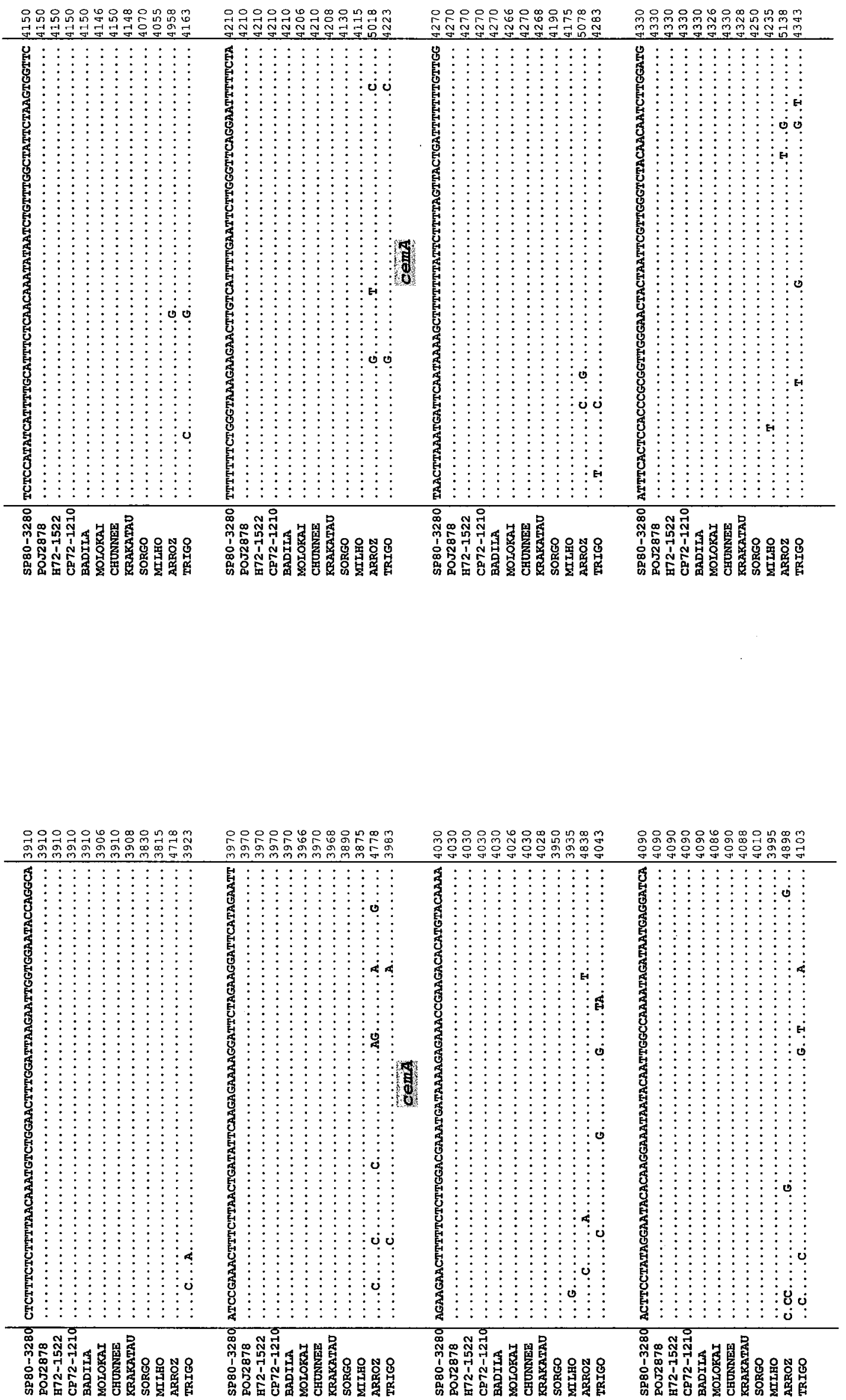

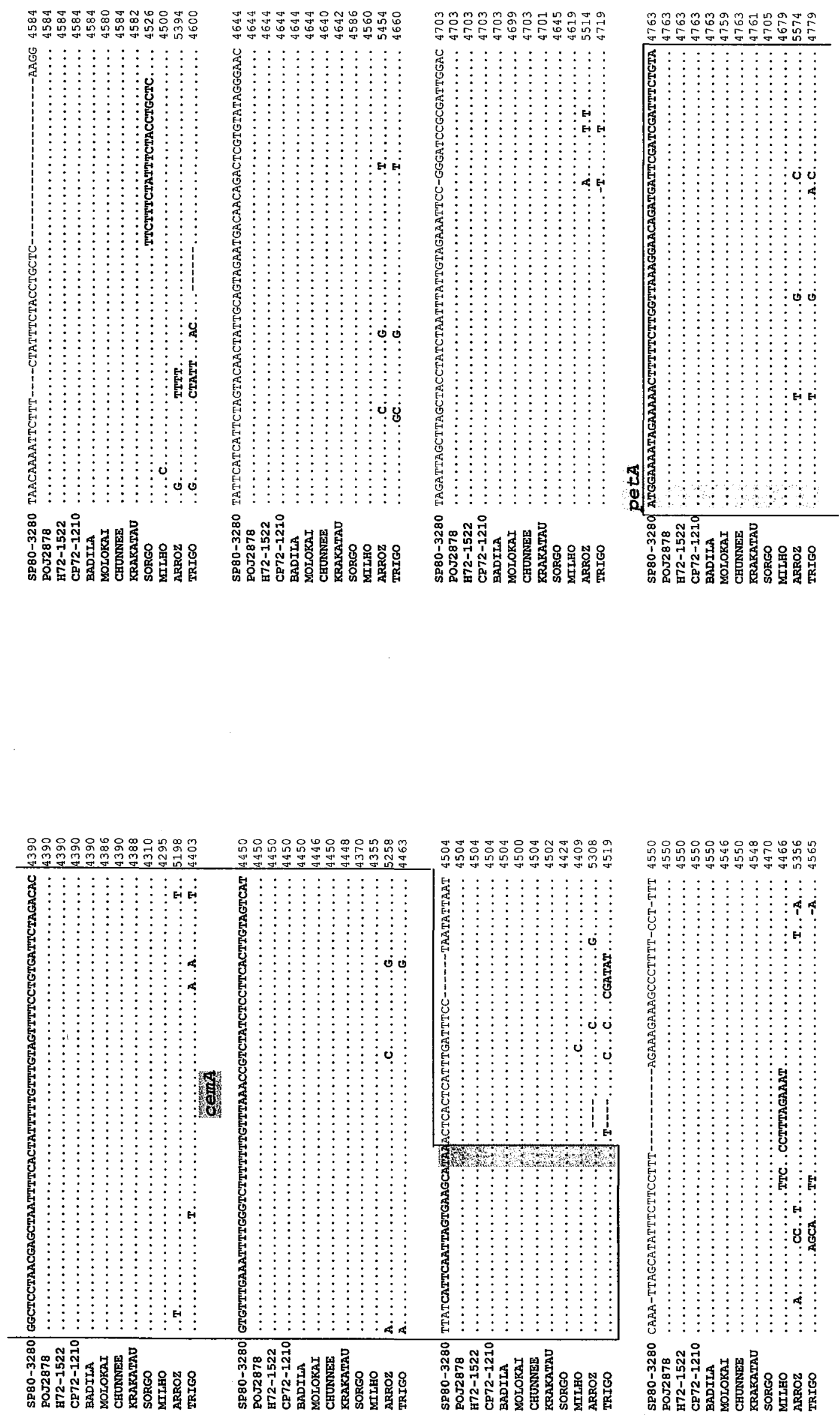

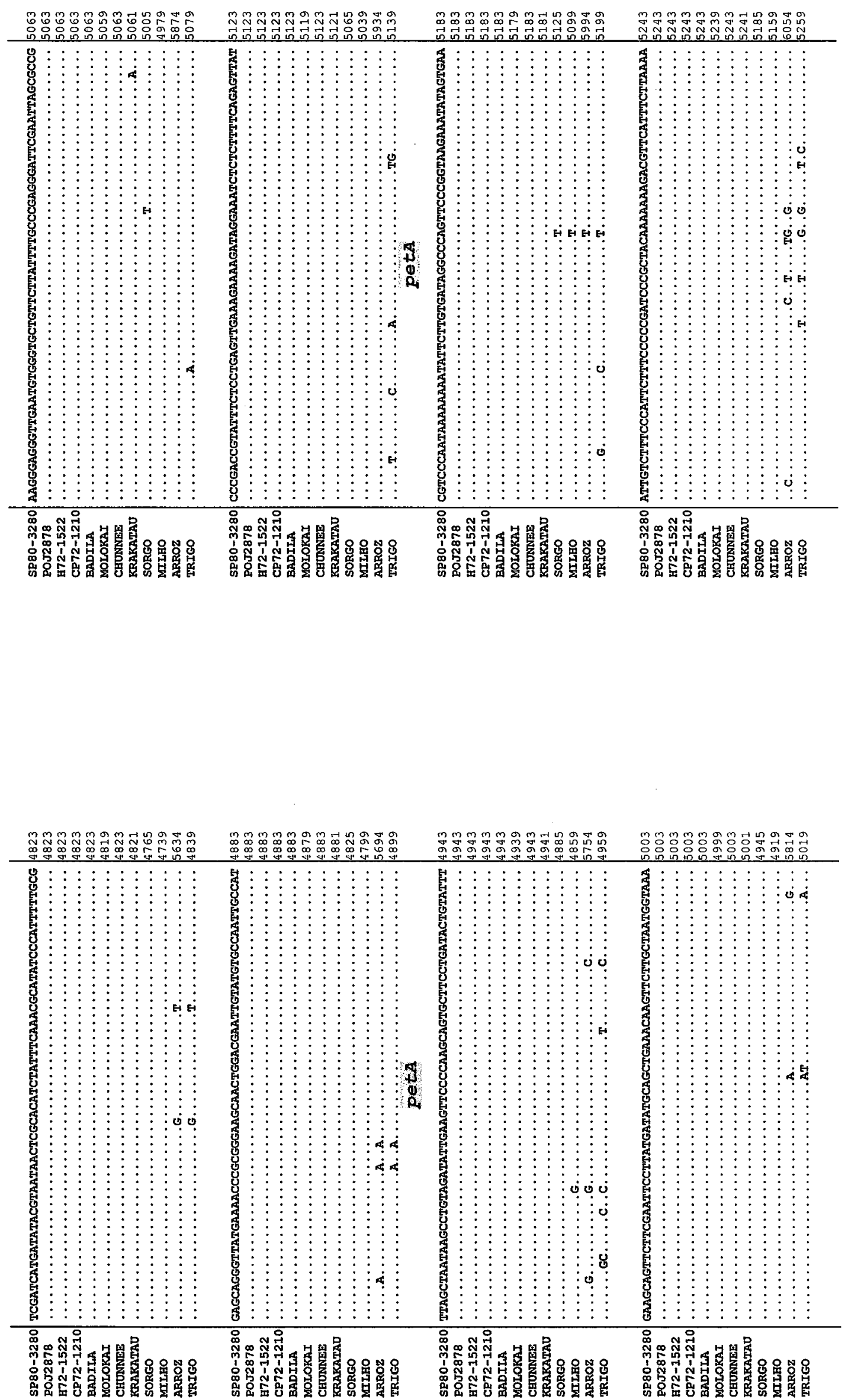

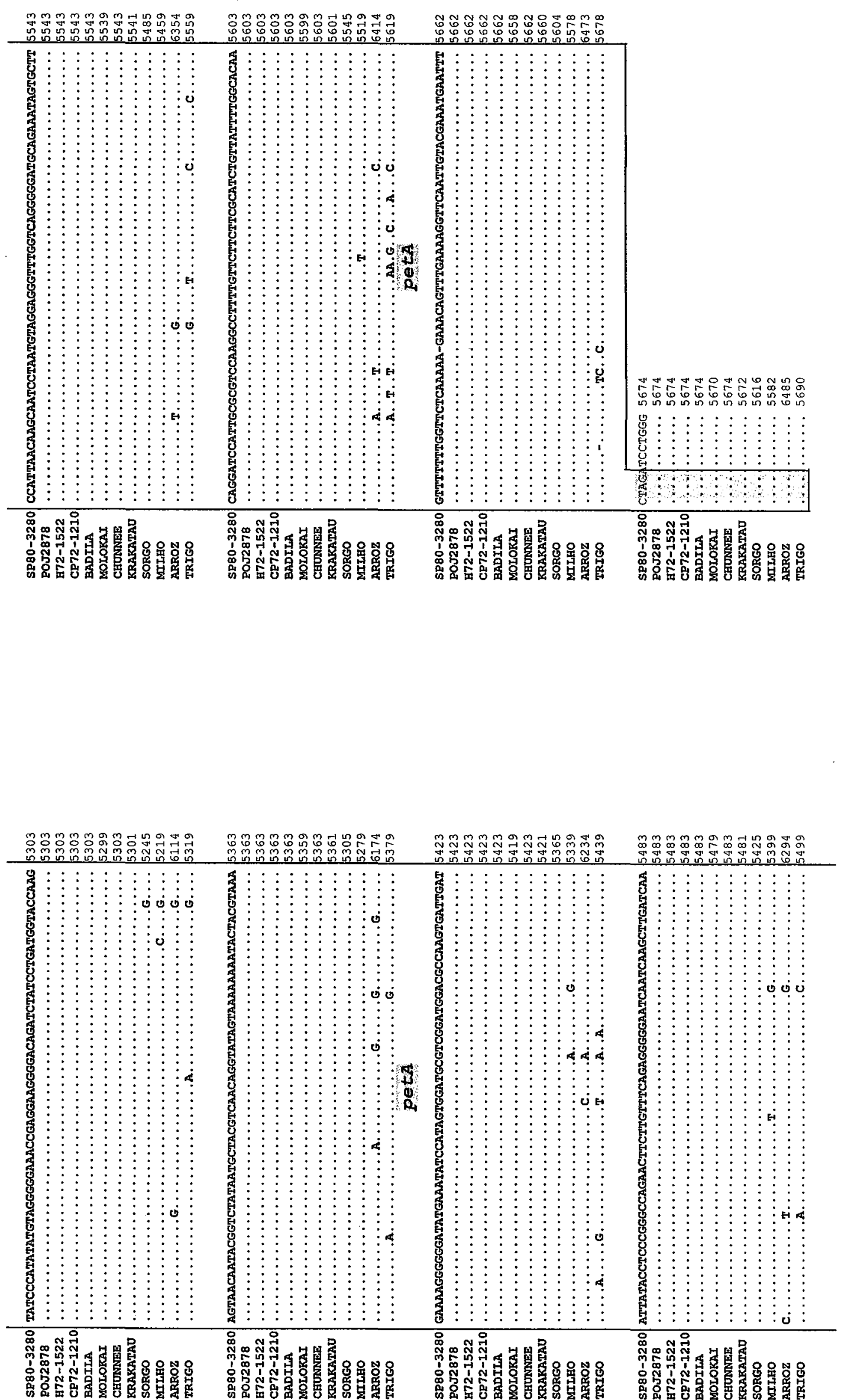
ANEXO E - Alinhamento das seqüências de nucleotídeos do DNA e do cDNA de sorgo, amplificadas com os primers desenhados nas regiões dos genes para análise de edição, comparadas com as mesmas seqüências de milho (Maier et al., 1995) e de cana-deaçúcar (Calsa Junior, 2001). As bases nitrogenadas sublinhadas indicam a posição do sítio de edição nos plastomas. A região do cDNA que não contém sítio de edição está circulada. Dados: cDNA: obtido de RNA total tratado com DNAse I; * Posição do códon de edição no plastoma de milho. 
- atpA:

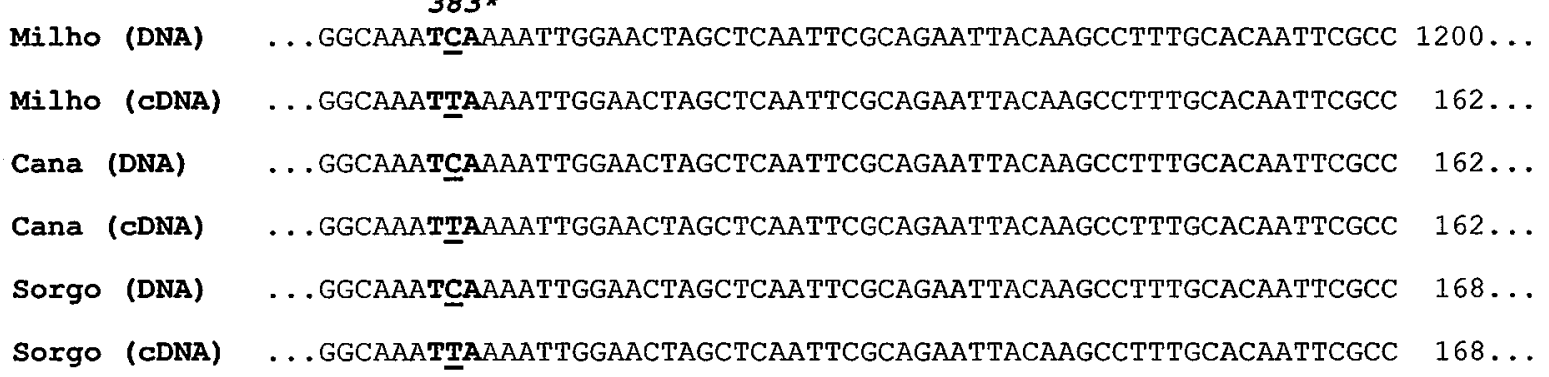

- ndhA:

17*

Milho (DNA) ...ATGATAATAGATAGGGTAGAGGTAGAAACTATCAATTCTTTTTCGGAAATCGGAATTATTT $60 \ldots$

Milho (CDNA) ....-...---GGGTAGAGGTAGAAACTATCAATTCTTTTTTGAAATCGGAATTATTT $47 \ldots$

Cana (DNA) ...-------GGGTAGAGGTAGAAACTATCAATTCTTTTTCGGAAATCGGAATTATTA $47 \ldots$

Cana (CDNA) ...-----

Sorgo (DNA) ...--

Sorgo (CDNA) ...----

Milho (DNA) …CCTATTGGTCTTCTCATGGCAGGATATAGCTCAAATAATAAATATTCTTTTTCAGGCGGT $480 \ldots$

Milho (CDNA) ...CCTATTGGTCTTCTCATGGCAGGATATAGCTCAAATAATAAATATTCTTTTTP黑AGGGGT $467 \ldots$

Cana (DNA) _..CCTATTGGTCTTCTCATGGCAGGATATAGCTCAAATAATAAATATTCTTTTTCEAGGCGGT $467 \ldots$

Cana (CDNA) ...CCTATTGGTCTTCTCATGGCAGGATATAGCTCAAATAATAAATATTCTTTTTTAGGCGGT $441 \ldots$

Sorgo (DNA) ...CCTATTGGTCTTCTCATGGCAGGATATAGCTCAAATAATAAATATTCTTTTTCAGGCGGT $447 \ldots$

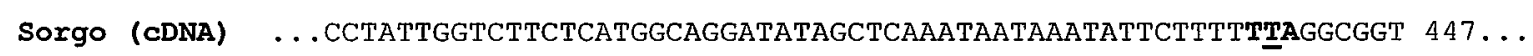

$188^{*}$
Milho (DNA) ...----TATCTAATAGTTCAAGTACAGTTGATATAGTTGAAGCACAGTCCAAATATGGTT $604 \ldots$

Milho (CDNA) ...CATCGA---CTATGATTTTAAGTACAGTTGATATAGTTGAAGCACAGTCCAAATATGGTT $1604 \ldots$

Cana (DNA) _..CATCGA---CTATGATTTCAAGTACAGTTGATATAGTTGAAGCACAGTCCAAATATGGTT $1603 \ldots$

Cana (CDNA) _.. TATGATTATCTAATAGTTPAAGTACAGTTGATATAGTTGAAGCACAGTCAAAATATGGTT $1349 \ldots$

Sorgo (DNA) ...-----TATCTAATAGTTCAAGTACAGTTGATATAGTTGAAGCACAGTCAAAATATGGTT $571 \ldots$

Sorgo (CDNA) ...-----TATCTAATAGTTTAAGTACAGTTGATATAGTTGAAGCACAGTCAAAATATGGTT $571 \ldots$ 


\begin{tabular}{|c|c|c|c|}
\hline Milho & (DNA) & ... TTCTTTTACCTATTTCTCTGGGCAATCTCTTATTAACAACTTCTTCCCCAACTAGTTTCAC & $1084 \ldots$ \\
\hline Milho & (CDNA) & . . TTCTTTTACCTATTTCTCTGGGCAATCTCTTATTAACAACTTCTTTCCAACTAGTTTCAC & $2084 \ldots$ \\
\hline Cana & (DNA) & ... TTCTTTTACCTATTTCTCTGGGCAATCTCTTATTAACAACTTCTTCCCAACTAGTTTCAC & 2083 . \\
\hline Cana & (CDNA) & . . TTCTTTTACCTATTTCTCTGGGCAATCTCTTATTAACAACTTCTTTCCAACTAGTTTCAC & 617 \\
\hline Sorgo & (DNA) & . . TTCTTTTACCAATTTTTCTGGGCAATCTCTTATTAACAACTTCTTCCCAACTAGTTTCAC & 870 \\
\hline & & . . TTCTTTTACCAATTTTTCTGGGCAATCTCTTATTAACAACTTCTTICCAACTAGTTTCAC & 870 \\
\hline
\end{tabular}

- ndhB:

Milho (DNA) ...ATGTTTTTATGTGGTGCTAACGATTTAATAACTATCTTTGTAGCTCCAGAATGTTTCAGT $480 \ldots$

Milho (cDNA) ...------GTGGTGCTAACGATTTAATAACTATCTTTGTAGCTCTAGAATGTTTCAGT 50...

Cana (DNA) ...---.-.

Cana (CDNA) ....

Sorgo (DNA) ....

Sorgo (CDNA) ........

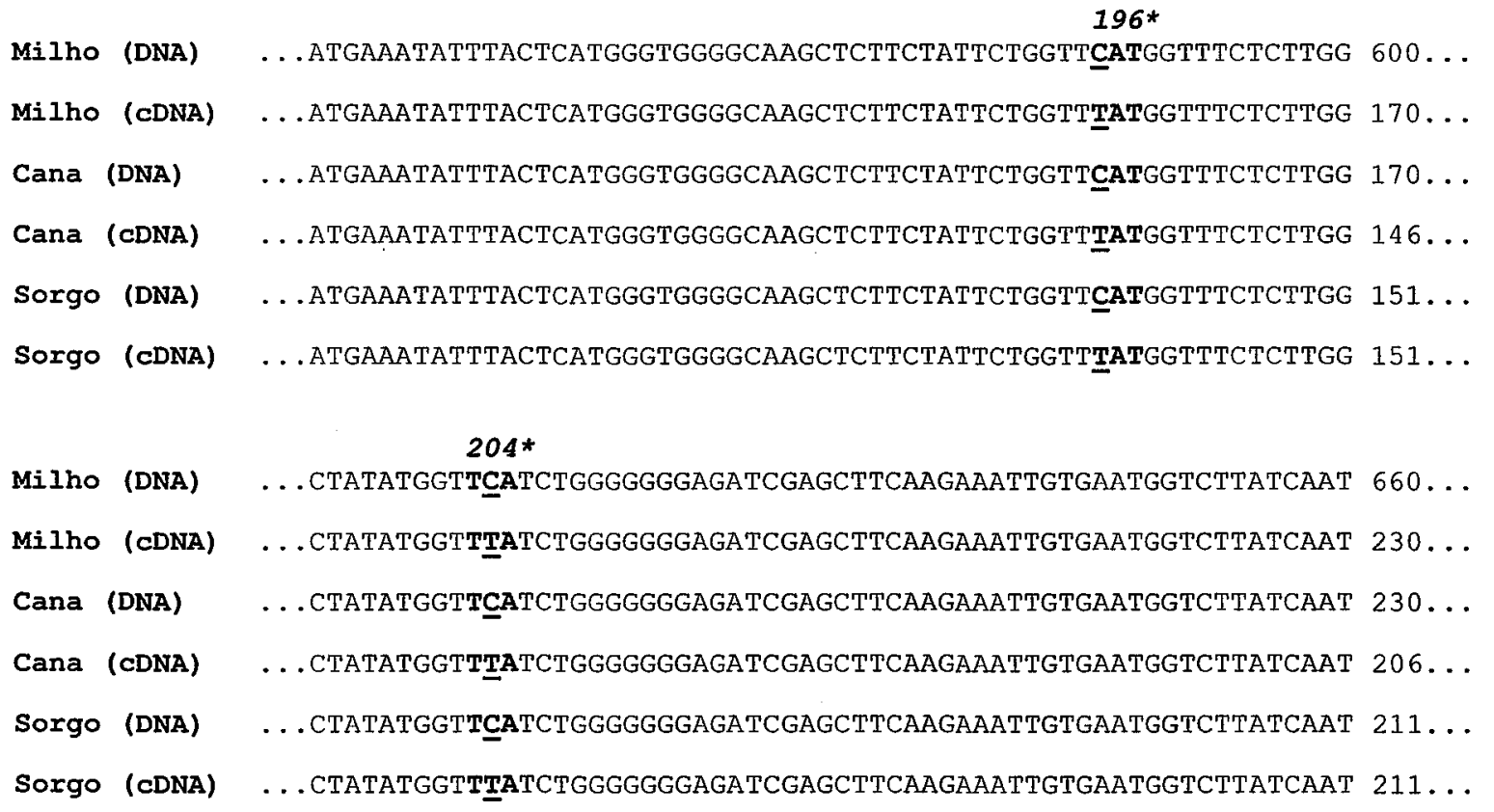




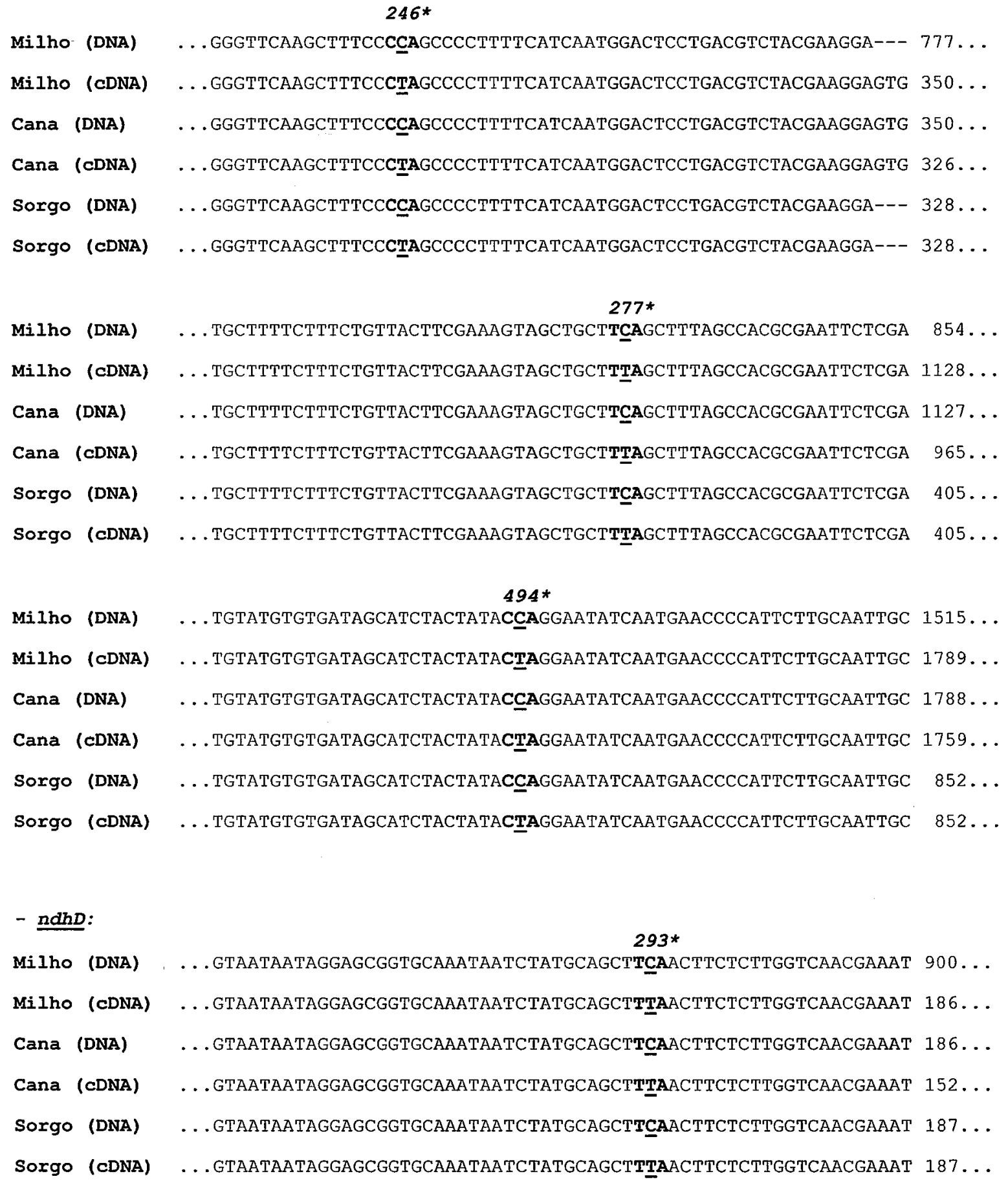


- $\underline{n d h F}:$

\begin{tabular}{|c|c|}
\hline Milho (DNA) & $\begin{array}{l}\text { 21* } \\
\text {... TCAATGGGATTTGGACTTTTTCTTATTCCTACAGCAACAAAAAATCTTCGTCGGATAT }\end{array}$ \\
\hline Milho (CDNA) & ...TIAATGGGATTTGGACTTTTTCTTATTCCTACAGCAACAAAAAATCTTCGTCGGATAT \\
\hline Cana (DNA) & . TCAATGGGATTTGGACTTTTTCTTATTCCCACAGCAACAAAAAATCTTCGTCGCATAT \\
\hline Cana (CDNA) & ... TTAATGGGATTTGGACTTTTTCTTATTCCCACAGCAACAAAAAATCTTCGTCGCATAT \\
\hline Sorgo (DNA) & ... TCAATGGGATTTGGACTTTTTCTTATTCCCACAGCAACAAAAAATCTTCGTCGCATAT \\
\hline Sorgo $(c$ & ATGGGATTTGGACTTTTTCTTATTCCCACAGCAACAAAAAATCTTCGTCGCATAT \\
\hline
\end{tabular}

- petB:

\begin{tabular}{|c|c|c|c|}
\hline Milho & (DNA) & $\begin{array}{l}\text { 204* } \\
\text {.. CCEAATGATACGTAAGCAAGGTATTTCGGGTCC-TTTATAG }\end{array}$ & 639. \\
\hline Milho & (CDNA) & . CTAATGATACGTAAGCAAGGTATTTCGGGTCC-TTTATAGGG & 296. \\
\hline Cana & (DNA) & . . CCEAATGATACGTAAGCAAGGTATTTCGGGTCC-TTTATAGGG & 296. \\
\hline Cana & (CDNA) & . CTAATGATACGTAAGCAAGGTATTTCGGGTCCGTTATAGGG & 317. \\
\hline Sorgo & & ...CEAATGATACGTAAGCAAGGTATTTCGGGTCCGTTATAGG & 351. \\
\hline orgo & (CDNA) & . CTAAATGATACGTAAGCAAGGTATTTCGGGTCCGTTATAGG & 51. \\
\hline
\end{tabular}

- IP12:

1*

Milho (DNA) ...-15 . .

Milho (CDNA) ...CCACTTCTAGATAGAGAAACGAACTAAAGGAGAATACTTAATAATATGGCGAAACATTTA 60...

Cana (DNA) ...CCACTTCTAGATAGAGAAACGAACTAAAGGAGAATACTTAATAATACGGCGAAACATTTA $60 \ldots$

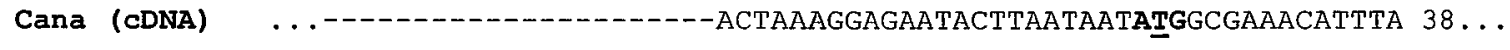

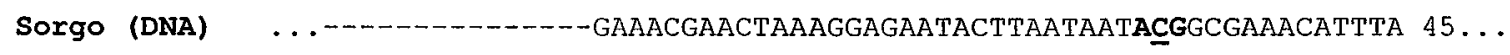

Sorgo (CDNA) .....-...-.

- xp120:

Milho (DNA) ...GCTGTATCAAATCCAAATAATCTTTACACGATTTCCAATAAAATAAGGATCATCAATTAA $360 \ldots$

Milho (cDNA) ...GCTGTATTAAATCCAAATAATCTTTACACGATTTCCAATAAAATAAGGATCATCAATTAA $317 \ldots$

Cana (DNA) ‥GCTGTATCAAATCCAAATAATCTTTACACGATTTCCAATAAAATAAGGATCATCAATTAA $317 \ldots$

Cana (cDNA) ...GCTGTATIAAATCCAAATAATCTTTACACGATTTCCAATAAAATAAGGATCATCAATTAA 289...

Sorgo (CDNA) ...GCTGTATCAAATCCAAATAATCTTTACACGATTTCCAATAAAATAAGGATCATCAATTAA 293...

Sorgo (DNA) ...GCTGTATIAAATCCAAATAATCTTTACACGATTTCCAATAAAATAAGGATCATCAATTAA 293... 
- xpoB:

156*

Milho (DNA) …ATTTCTATATATACCGGGACTATAATATCAGATTGGGGAGGAAGGTCGGAATTAGCAATT 480... Milho (CDNA) ...ATTTCTATATATACCGGGACTATAATATCAGATTGGGGAGGAAGGTTGGAATTAGCAATT $133 \ldots$ Cana (DNA) …ATTTCTATATGCACCGGTACTATAATATCAGATTGGGGAGGAAGGTCGGAATTAGCAATT $133 \ldots$ Cana (CDNA) ...ATTTCTATATACACCGGTACTATAATATCAGATTGGGGAGGAAGGTTGGAATTAGCAATT $133 \ldots$ Sorgo (DNA) …ATTTCTATATACACCGGTACTATAATATCAGATTGGGGAGGAAGGTCGGAATTAGCAATT $135 \ldots$ Sorgo (CDNA) ...ATTTCTATATACACCGGTACTATAATATCAGATTGGGGAGGAAGGTTGGAATTAGCAATT $135 \ldots$

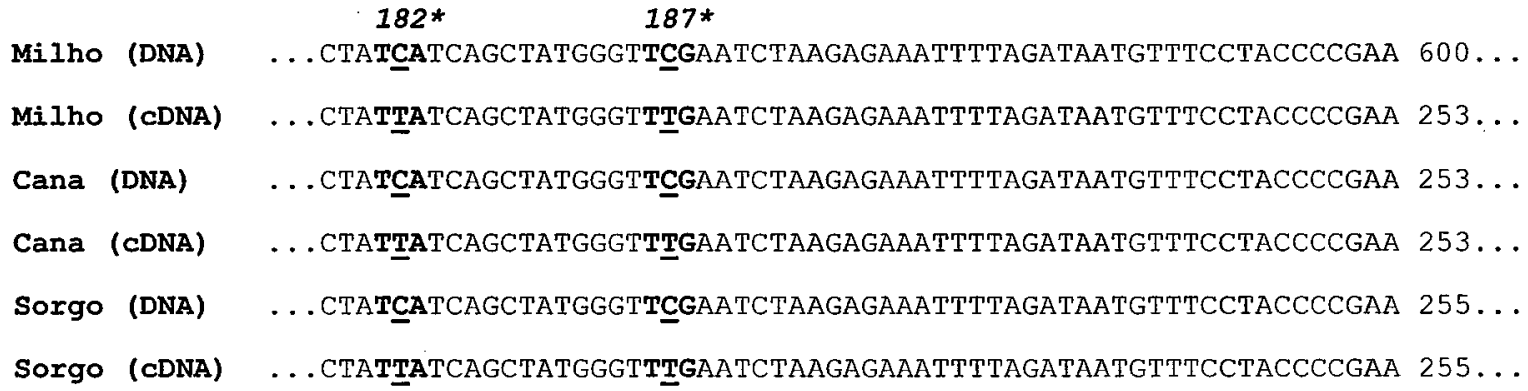
206*

Milho (DNA) ...ATTTTCTTGTCTTTCCCGAATGCTAAGGAGAAGAAGAGGATTGAGTCAAAAGAAAAAGCT $660 \ldots$ Milho (cDNA) ...ATTtTCTTGTCTTTCCTGAATGCTAAGGAGAAGAAGAGGATTGAGTCAAAAGAAAAAGCT $313 \ldots$ Cana (DNA) ...ATTTTCTTGTCTTTCCCGAATGCTAAGGAGAAGAAGAGGATTGAGTCAAAAGAAAAAGCT $313 \ldots$ Cana (CDNA) ...ATTTTCTTGTCTTTCCGg) Soxgo (DNA) …ATTTTCTtGTCTTTCCCGAATGCTAAGGAGAAGAAGAGGATTGAGTCAAAAGAAAAAGCT $315 \ldots$ Sorgo (cDNA) ...ATTTTCTTGTCTTTCCTGAATGCTAAGGAGAAGAAGAGGATTGAGTCAAAAGAAAAAGCT $315 \ldots$

- rpoc2:

Milho (DNA) ...AAGTATTTTGTTTCGGTTCGACCTGCAGTCGCATATGAAATGGACGAAGgGATAAATTTA $2820 \ldots$ Milho (CDNA) ...AAGTATTTTGTTTTGGTTCGACCTGCAGTCGCATATGAAATGGACGAAGGGATAAATTTA $201 \ldots$ Cana (DNA) …AAGTATTTTGTTTCEGGTCGACCTGCAGTCGCATATGAAATGGACGAAGGGAGAAATTTA $204 \ldots$ Cana (CDNA) ...AAGTATTTTGTTTPTGGTCGACCTGCAGTCTCATATGAAATGGACGAAGGGGAAATTA $204 \ldots$ Sorgo (DNA) . . AAGTATTTTGTTTCGGTTCGACCTGCAGTCTCATATGAAATGGACGAAGGGAGAAATTTA $209 \ldots$ Sorgo (CDNA) ...AAGTATTTTGTTTTGGTTCGACCTGCAGTCTCATATGAAATGGACGAAGGGAGAAATTTA $209 \ldots$ 
- IPS14:

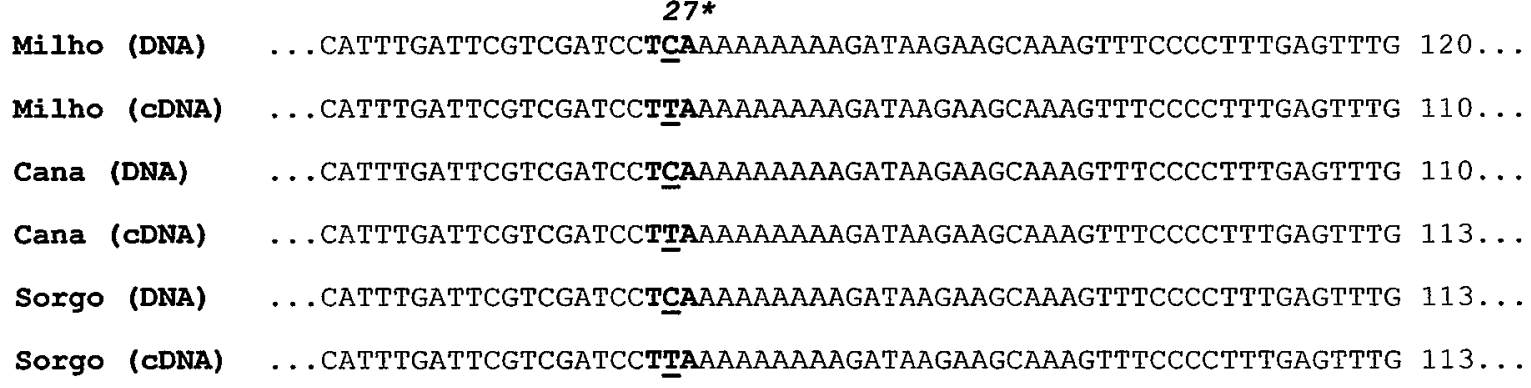

- xps8:

Milho (DNA) ...TEAACTTTGCGACATCAAAGGAGAAAGACTAGAAAGGGAATATATAGAACTAGAACCTTT $240 \ldots$

Milho (CDNA) ... TIAACTTTGCGACATCAAAGGAGAAAGACTAGAAAGGGAATATATAGAACTAGAACCTTT $174 \ldots$

Cana (DNA) ... TCAACTTTGCGACATCAAAGGAGAAAGACTAGAAAGGGAATATATAGAACTAGAACCTTT $174 \ldots$

Cana (cDNA) ... TIIAACTTTGCGACATCAAAGGAGAAAGACTAGAAAGGGAATATATAGAACTAGAACCTTT $144 \ldots$

Sorgo (DNA) ...TCAACTTTGCGACATCAAAGGAGAAAGACTAGAAAGGGAATATATAGAACTAGAACCTTT $165 \ldots$

Sorgo (CDNA) ...TEACTTTGCGACATCAAAGGAGAAAGACTAGAAAGGGATATATAGAACTAGAACCTTT $198 \ldots$

- ycf3:

15*

Milho (DNA) ...ATGCCTAGATCCCGTATAAATGGAAATTTCATTGATAAGACCTCCTCGATTGTAGCCAAT $60 \ldots$

Milho (CDNA) ....................

Cana (DNA) ...---.-.-.-. TCATTGATAAGACCTCCTCGATTGTAGCCAAT 32...

Cana (CDNA) ....-....

Sorgo (DNA) ....--

Sorgo (cDNA) ......-. TCATTGATAAGA CTC

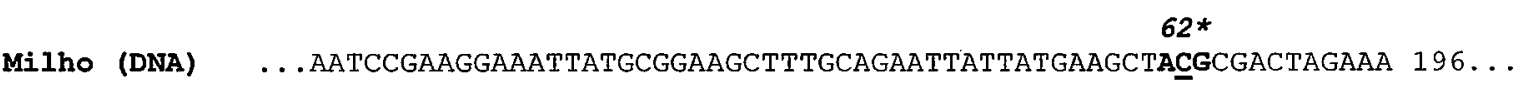

Milho (CDNA) …AATCCGAAGGAAATTATGCGGAAGCTTTGCAGAATTATTATGAAGCTATGCGACTAGAAA 904...

Cana (DNA) ...AATCCGAAGGAAATtATGCGGAAGCTTtGCAGAATTATTATGAAGCTACGCGACTAGAAA 900...

Cana (CDNA) …AATCCGAAGGAAATTATGCGGAAGCTTTGCAGAATTATTATGAAGCTATGCGACTAGAAA $911 \ldots$

Sorgo (DNA) …AATCCGAAGGAAATTATGCGGAAGCTTCGCAGAATTATTATGAAGCTACGCGTCTAGAAA $191 \ldots$

Sorgo (CDNA) ...AATCCGAAGGAAATTATGCGGAAGCTTCGCAGAATTATTATGAAGCTATGCGTCTAGAAA $191 \ldots$ 


\section{REFERÊNCIAS BIBLIOGRÁFICAS}

ADACHI, J.; WADDELL, P.J.; MARTIN, W.; HASEGAWA, M. Plastid genome phylogeny and a model of amino acid substitution for proteins encoded by chloroplast DNA. Journal of Molecular Evolution, v.50, p.348-358, 2000.

AL-JANABI, S.M.; McCLELLAND, M.; PETERSEN, C.; SOBRAL, B.W.S. Phylogenetic analysis of organellar DNA sequences in the Andropogoneae: Saccharinae. Theoretical and Applied Genetics, v.88, p.933-944, 1994.

ALTSCHUL, S.F.; GISH, W.; MILLER, W.; MYERS, E.W.; LIPMAN, D.J. Basic Local alignment search tool. Journal of Molecular Biology, v.215, n.3, p.403-410, 1990.

BACCI JUNIOR, M.; MIRANDA, V.F.O.; MARTINS, V.G. et al. A search for markers of sugarcane evolution. Genetics and Molecular Biology, v.24, p.169-174, 2001.

BAGINSKY, S.; GRUISSEM, W. Chloroplast proteomics: potentials and challenges. Journal of Experimental Botany, v.55, p.1213-1220, 2004.

BAKER, W.J.; HEDDERSON, T.A.; DRANSFIELD, J. Molecular phylogenetics and subfamily Calamoideae (Palmae) based on nrDNA ITS and cpDNA rps16 intron sequence data. Molecular Phylogenetics and Evolution, v.14, n.2, p.195-217, 2000 .

BERDING, N.; ROACH, B.T. Germplasm collection, maintenance, and use. In: HEINZ, D.J. (Ed.). Sugarcane improvement through breeding: Developments in crop science. Amsterdam: Elsevier, 1987. v. 11, p.143-210.

BIOLOGICAL SEQUENCE ALIGNMENT EDITOR FOR WIN95/98/NT/2K/XP (BIOEDIT SEQUENCE ALIGNMENT EDITOR). http://www.mbio.ncsu.edu/BioEdit/bioedit.html. (15 Apr. 2004).

BIRBOIM, H.C.; DOLY, J. A rapid alkaline extraction procedure for screening recombinant plasmid DNA. Nucleic Acids Research, v.7, n.6, p.1513-1523, 1979. 
BIRKY, C.W. Evolution and variation in plant chloroplast and mitochondrial genomes. In: GOTTLIEB, L.D.; JAIN, S.K. (Ed.). Plant Evolutionary Biology. London: Chapman and Hall, 1988. p.23-53.

BIRKY, C.W.; MARUYAMA, T.; FUERST, P. An approach to population and evolutionary genetic theory for genes in mitochondrial and chloroplasts, and some results. Genetics, v.103, p.513-527, 1983.

BLÄSING, O.E.; ERNST, K.; STREUBEL, E.M.; WESTHOFF, P.; SVENSSON, P. The non-photosynthetic phosphoenolpyruvate carboxylases of the $\mathrm{C}_{4}$ dicot Flaveria trinervia - implications for the evolution of $\mathrm{C}_{4}$ photosynthesis. Planta, v.215, p.448-456, 2002.

BOXSHADE 3.21 - PRETTY PRINTING AND SHADING OF MULTIPLEALIGNMENT FILES. http://www.ch.embnet.org/software/BOX_form.html. (15 Apr. 2004).

BOWMAN, C.M.; BARKER, R.F.; DYER, T.A. In wheat ctDNA, segments of ribosomal proteins genes are dispersed repeats, probably conserved by nonreciprocal recombination. Current Genetics, v.14, p.127-136, 1988.

BOCK, R. Sense from nonsense: how the genetic information of chloroplasts is altered by RNA editing. Biochimie, v.82, p.549-557, 2000.

BRAIDWOOD, R.J. Prehistoric Men. 6.ed. Chicago: Natural History Museum Press, 1948. 189p.

BRANDES, E.W.; SARTORIS, G.B.; GRASSL, C.O. Assembling and evaluating wild forms of sugarcane and closely related plants. In: INTERNATIONAL SOCIETY OF SUGARCANE TECHNOLOGY CONGRESS, 22., Colombia, 1939. Proceedings. Colombia: Technicana, 1939. p.128-154.

BRENNICKE, A.; MARCHFELDER, A.; BINDER, S. RNA editing. FEMS Microbiology Review, v.23, p.297-316, 1999.

BURNQUIST, W.B. Development and application of restriction fragment length polymorphism technology in sugarcane (Saccharum spp.) breeding. Ithaca N.Y., 1991. 81p. Thesis (Ph.D) - Cornell University.

CALSA JUNIOR, T. Sequenciamento e análise do genoma cloroplastidial de cana-deaçúcar (Saccharum officinarum). Piracicaba, 2001. 76p. Dissertação (Mestrado) Escola Superior de Agricultura "Luiz de Queiroz", Universidade de São Paulo. 
CATALAN, M.P.; KELLOGG, E.A.; OLMSTEAD, R.G. Phylogeny of Poaceae subfamily Pooideae based on chloroplast $n d h F$ gene sequences. Molecular Phylogenetics and Evolution, v.8, p.150-166, 1997.

CELARIER, R.P. Cytotaxonomy of the Andropogoneae. I. Subtribes Dimeriinae and Saccharinae. Cytologia, v.21, p.272-291, 1956.

CHANDRASEKHARAN, U.M.; SANKER, S.; GLYNIAS, M.J. et al. Angiotensin IIforming activity in a reconstructed ancestral chymase. Science, v.271, p.502-505, 1996.

CHASE, M.W.; SOLTIS, D.E.; OLMSTEAD, R.G. et al. Phylogenetics of seed plants: an analysis of nucleotide sequences from the plastid gene $r b c L$. Annual Missouri Botanical Garden, v.80, p.528-580, 1993.

CHU, K.H.; QI, J.; YU, Z.G.; ANH, V. Origin and phylogeny of chloroplasts revealed by a simple correlation analysis of complete genomes. Molecular Phylogenetics and Evolution, v.1, p.200-206, 2003.

CIPRIANI, G.; TESTOLIN, R.; MORGANTE, M. Paternal inheritance of plastids in interspecific hybrids of the genus Actinidia revealed by PCR-amplification of chloroplast DNA fragments. Molecular Genetics and Genomics, v.247, p.693-697, 1995.

CLARK, L.G.; ZHANG, W.; WENDEL, J.F. A phylogeny of the grass family (Poaceae) based on $n d h F$ sequence data. Systematics of Botanics, v.20, p.436-460, 1995.

CLAYTON, W.D.; RENVOIZE, S.A. Genera Graminum: grasses of the world. London: Her Majesty's Stationary Office, 1986. 897p. (Kew Bulletin Additional Series, 13.).

CLEGG, M. T.; LEARN, G. H.; GOLENBERG, E. M. Molecular evolution of chloroplast DNA. In: SELANDER, R.K.; CLARK, A. G.; WHITTAM, T. S. (Ed.). Evolution at the molecular level. Sunderland, Mass.: Sinauer, 1991. p.135-149.

CLEGG, M.T.; GAUT, B.S.; LEARN, G.H.; MORTON, B.R. Rates and patterns of chloroplast DNA evolution. Proceedings of the National Academy of Sciences of the USA, v.91, p.6795-6801, 1994.

CORNEILLE, S.; LUTZ, K.; MALIGA, P. Conservation of RNA editing between rice and maize plastids: are most editing events dispensable? Molecular and General Genetics, v.264, p.419-424, 2000. 
CORPET, F. Multiple sequence alignment with hierarchical clustering, Nucleic Acids Research, v.16, n.22, p.10881-10890, 1988.

CRANE, P.R.; FRIIS, E.M.; PEDERSEN, K.R. The origin and early diversification of angiosperms. Nature, v.374, p.27-33, 1995.

CUMMINGS, M.P.; KING, L.M.; KELLOGG, E.A. Slipped-strand mispairing in a plastid gene: $r$ poC2 in grasses (Poaceae). Molecular Biology and Evolution, v.11, p.1-8, 1994.

DAHLGREN, R.M.T.; CLIFFORD, H.T.; YEO, P.F. The families of the monocotyledons: Structure, evolution and taxonomy. Berlin: Springer-Verlag, 1985. $48 \mathrm{p}$.

DANIELS, J., ROACH, B.T. Taxonomy and evolution in sugarcane. In: HEINZ, D. J. (Ed.). Sugarcane Improvement Through Breeding. Amsterdam: Elsevier Press, 1987. v.11, p.7-84.

DE LAS RIVAS, J., LOZANO, J.J.; ORTIZ, A.R. Comparative analysis of chloroplast genomes: Functional annotation, genome-based phylogeny, and deduced evolutionary patterns. Genome Research, v.12, p.567-583, 2002.

DELWICHE, C. F. Tracing the thread of plastid diversity through the tapestry of life. American Naturalist, v.154, p.S164-S177, 1999.

DEMESURE, B.; SOZI, N.; PETIT, R.J. A set of universal primers for amplification of polymorphic non-coding regions of mitochondrial and chloroplast DNA in plants. Molecular Ecology, v.4, p.129-131, 1995.

DOEBLEY, J.; RENFROE, W.; BLANTON, A. Restriction site variation in the Zea chloroplast genome. Genetics, v.117, p.139-147, 1987.

DOEBLEY, J.; DURBIN, M.; GOLENBERG, E.M.; CLEGG, M.T.; MA, D.P. Evolutionary analysis of the large subunit of carboxilase $(r b c L)$ nucleotide sequence among the grasses (Gramineae). Evolution, v.44, p.1097-1108, 1990.

DOWNIE, S.R.; PALMER, J.D. Use of chloroplast DNA rearrangements in reconstructing plant phylogeny. In: SOLTIS, P.S.; SOLTIS, D.E.; DOYLE, J.J. (Ed.). Molecular systematics of plants. New York: Chapman and Hall, 1992. p.14-35.

DOWNIE, S.R.; KATZ-DOWNIE, D.S. Phylogenetic analysis of chloroplast rps16 intron sequences reveals relationships within the woody southern african Apiaceae subfamily Apioideae. Canadian Journal of Botany, v.77, p.1120-1135, 1999. 
DOYLE, K.; DOYLE, J. Plant DNA miniprep. Focus, v.12, p.1, 1990.

DRESCHER, A.; RUF, S.; CALSA JUNIOR, T.; CARRER, H.; BOCK, R. The two largest chloroplast genome-encoded open reading frames of higher plants are essential genes. Plant Journal, v.22, p.97-104, 2000.

DUMOLIN-LAPEGUE, S.; PEMONGE, M.H.; PETIT, R.J. An enlarged set of consensus primers for the study for the organelle DNA in plants. Molecular Ecology, v.6, p.393-397, 1997.

ECK, R.V.; DAYHOFF, M.O. Atlas of protein sequence and structure. Silver Springs, MD: Natl. Biomed. Res. Found, 1966. 1v.

EDWARDS, G.E.; HUBER, S.C. The $\mathrm{C}_{4}$ pathway. In: HATCH, M.D.; BOARDMAN, N.K. (Ed.). The biochemistry of plants: photosynthesis. New York: Academic Press, 1981. v.8, p.238-281.

EMPRESA BRASILEIRA DE PESQUISA AGROPECUÁRIA MILHO E SORGO (EMBRAPA MILHO E SORGO). http://www.cnpms.embrapa.br/. (15 abr. 2004).

EMPRESA BRASILEIRA DE PESQUISA AGROPECUÁRIA ARROZ E FEIJÃO (EMBRAPA ARROZ E FEIJÃO). http://www.cnpaf.embrapa.br/. (15 abr. 2004).

EMPRESA BRASILEIRA DE PESQUISA AGROPECUÁRIA TRIGO (EMBRAPA TRIGO). http://www.cnpt.embrapa.br/. (15 abr. 2004).

EWING, B.; GREEN, P. Base-calling of automated sequencer traces using phred. II. Error probabilities. Genome Research, v.8, p.186-194, 1998.

EWING, B.; HILLIER, L.; WENDL, M.C.; GREEN, P. Base-calling of automated sequencer traces using phred. I. Accuracy assessment. Genome Research, v.8, p.175-185, 1998.

FELSENSTEIN, J. Confidence limits on phylogenies: an approach using the bootstrap. Evolution, v.39, p.783-791, 1985.

FITCH, W.M. Toward defining the course of evolution: minimum change for a specific tree topology. Systematics of Zoology, v.20, p.406-416, 1971.

FITZ-GIBBON, S. T.; HOUSE, C.H. Whole genome-based phylogenetic analysis of free-living microorganisms. Nucleic Acids Research, v.27, p.4218-4222, 1999.

GAUT, B.S.; CLEGG, M.T. Molecular evolution of the AdhI locus in the genus Zea. Proceedings of the National Academy of Sciences of the USA, v.90, p.5095-5099, 1993. 
GLASZMANN, J.C.; NOYER, J.L.; FAUTRET, A. et al. Biochemical genetic markers in sugarcane. Theoretical and Applied Genetics, v.78, p.537-543, 1989.

GLASZMANN, J.C.; LU, Y.H.; LANAUD, C. Variation of nuclear ribosomal DNA in sugarcane. Journal of Genetic Breeding, v.44, p.191-198, 1990.

GORDON, D.; ABAJIAN, C.; GREEN, P. Consed: a graphical tool for sequence finishing. Genome Research, v.8, p.195-2002, 1998.

GOULDING, S.E.; OLMSTEAD, R.G.; MORDON, C.W.; WOLFE, K.H. Ebb and flow of the chloroplast inverted repeat. Molecular and General Genetics, v.252, p.195-206, 1996.

GRAY, M.W. The origin and evolution of plastid genomes and genes. In: BOGORAD, L.; VASIL, I.K. (Ed.). The Molecular Biology of Plastids. Cell culture and somatic cell genetics of plants. San Diego, CA: Academic Press, 1991. v.7, cap.11, p.5-53.

GRIVET, L.; ARRUDA, P. Sugarcane genomics: depicting the complex genome of an important tropical crop. Current Opinion of Plant Biology, v.2, p.122-127, 2002.

HALL, T.A. BioEdit: a user-friendly biological sequence alignment editor and analysis program for Windows 95/98/NT. Nucleic Acids Symposium Series, v.41, p.95-98, 1999.

HARTLEY, W. Studies on the origin, evolution, and distribution of the Gramineae. I. The tribe Andropogoneae. Australian Journal of Botany, v.6, p.116-128, 1958.

HATCH, M.D. Photosyntesis: The Path of Carbon. New York: Academic, 1976. p.191-844.

HEINZ, D.J. Sugarcane improvement through breeding: Developments in crop science. Amsterdam: Elsevier, 1987. v. 11, p.578-582.

HERRMANN, R.G. Eukaryotism, towards a new interpretation. In: HEA, S.; HERRMANN, R.G.; JEON, K.W.; SCHWEMMLER, W. (Ed.). Eukaryotism and Symbiosis. Heidelberg, Germany: Springer, 1997. p. 73-118.

HILU, K.W.; ALICE, L.A. Evolutionary implications of matK indels in Poaceae. American Journal of Botany, v.86, p.1735-1741, 1999.

HIRATSUKA, J.; SHIMADA, H.; WHITTIER, R. et al. The complete sequence of the rice (Oryza sativa) chloroplast genome: intermolecular recombination between distinct tRNA genes accounts for a major plastid DNA inversion during the evolution of the cereals. Molecular and General Genetics, v.217, p.185-194, 1989. 
HOCH, B.; MAIER, R.M.; APPEL, K. et al. Editing of a chloroplast mRNA by creation of an initiation codon. Nature, v.353, p.178-180, 1991.

HONG, Y.P.; HIPKINS, V.D.; STRAUSS, S.H. Chloroplast DNA diversity among trees, populations and species in the California closed-cone pines (Pinus radiata, Pinus muricata and Pinus attenuata). Genetics, v.135, p.1187-1196, 1993.

HOWE, C.J.; BARKER, R.F.; BOWMAN, C.M.; DYER, T.A. Common features of three inversions in wheat chloroplast DNA. Current Genetics, v.13, n.4, p.343-349, 1988.

HUPFER, H.; SWIATEK, M.; HORNUNG, S. et al. Complete nucleotide sequence of the Oenothera elata plastid chromosome, representing plastoma I of the five distinguishable Euoenothera plastomes. Molecular Genetics and Genomics, v.263, p.581-585, 2000.

IGLOI, G.L.; MEINKE, A.; DORY, I.; KOSSEL, H. Nucleotide sequence of the maize chloroplast $\mathrm{rpoB} / \mathrm{Cl} / \mathrm{C} 2$ operon: comparison between the derived protein primary structures from various organisms with respect to functional domains. Molecular Genetics and Genomics, v.221, p.379-394, 1990.

INGVARSSON, P.K.; RIBSTEIN, S.; TAYLOR, D.R. Molecular evolution of insertions and deletions in the chloroplast genome of Silene. Molecular Biology and Evolution, v.20, p.1737-1740, 2003.

JERMANN, R.M.; OPITZ, J.G.; STACKHOUSE, J.; BENNER, S.A. Reconstructing the evolutionary history of the artiodactyl ribonuclease superfamily. Nature, v.374, p.57-59, 1995.

JOHNSON, L.A.; SOLTIS, D.E. matK DNA sequences and phylogenetic reconstruction in Saxifragaceaes. Systematics of Botanic, v.19, p.143-156, 1994.

KANEKO, T.; SATO, S.; KOTANI, H. Sequence analysis of the genome of the unicellular cyanobacterium Synechocystis sp. strain PCC6803. II. Sequence determination of the entire genome and assignment of potential protein-coding regions. DNA Research, v.3, p.109-136, 1996.

KATAYAMA, H.; OGIHARA, Y. Phylogenetic affinities of the grasses to other monocots as reveled by molecular analysis of chloroplast DNA. Current Genetics, v.29, n.6, p.572-581, 1996.

KATO, T.; KANEKO, T.; SATO, S. et al. Complete structure of the chloroplast genome of a legume, Lotus japonicus. DNA Research, v.7, n.6, p.323-330, 2000. 
KELCHNER, S.A. The evolution of noncoding chloroplast DNA and its application in plant systematics. Annual Missouri Botanical Garden, v.87, p.482-498, 2000.

KELCHNER, S. A.; WENDEL, J.F. Hairpins create minute inversions in non-coding regions of chloroplast DNA. Current of Genetics, v.30, p.259-262, 1996.

KELLOGG, E.A. Relationships of cereal crops and other grasses. Proceedings of the National Academy of Sciences of the USA, v.95, p.2005-2010, 1998.

KELLOGG, E.A. Phylogenetic aspects of the evolution of $\mathrm{C}_{4}$ photosynthesis. In: SAGE, R.F., MONSON, R.K. (Ed.). Phylogenetic aspects of the evolution of $\mathbf{C}_{\mathbf{4}}$ photosynthesis. San Diego: Academic Press, 1999. p. 411-444.

KELLOGG, E.A.; WATSON, L. Phylogenetic studies of a large data set. I. Bambusoideae, Andropogonodae, and Pooidae (Gramineae). Botanical Review, v.59, p.273-343, 1993.

KIM, K.-J.; JANSEN, R.K. $n d h F$ sequence evolution and the major clades in the sunflower family. Proceedings of the National Academy of Sciences of the USA, v.92, p.10379-10383, 1995.

KOCHERT, G.; HALWARD, T.; BRANCH, W.D.; SIMPSON, C.E. RFLP variability in peanut (Arachis hypogaea L.) cultivars and wild species. Theoretical and Applied Genetics, v.81, p.565-570, 1991.

LATZKO, E.; KELLY, J. The multi-faceted function of phosphoenolpyruvate carboxylase in $\mathrm{C}_{3}$ plants. Physiology of Vegetables, v.21, p.805- 815, 1983.

LEE, C.; WEN, J. Phylogeny of Panax using chloroplast $t r n C-t r n D$ intergênica region and the utility of $\operatorname{trn} C-\operatorname{trn} D$ in interspecific studies of plants. Molecular Phylogenetics and Evolution, v.31, n.3, p.1-10, 2004.

LEECH, R.M.; THOMSON, W.W.; PLATT-ALOIA, K.A. Observations of the mechanism of chloroplast division in higher plants. New Phytologist, v.87, p.1-9, 1981.

LEISTER, D. Chloroplast research in the genomic age. Trends in Genetics, v.19, p.47-56, 2003.

LEMIEUX, C.; OTIS, O.; TURMEL, M. Ancestral chloroplast genome in Mesostigma viride reveals an early branch of green plant evolution. Nature, v.403, p.649-652, 2000.

LEVINSON, G.; GUTMAN, G.A. Slipped-strand mispairing: a major mechanism for DNA sequence evolution. Molecular Biology and Evolution, v.4, p.203-221, 1987. 
LIN, J.; GERSTEIN, M. Whole-genome trees based on the occurrence of folds and orthologs, implications for comparing genomes at different levels. Genome Research, v.10, p.808-818, 2000.

LISTON, A.; ROBINSON, W.A.; OLIPHANT, J.M.; ALVAREZ-BUYLLA, E.R. Length variation in the nuclear ribosomal DNA internal transcribed spacer region of non-flowering seed plants. Systematics of Botany, v.21, p.109-120, 1996.

LU, Y.H.; D'HONT, A.; PAULET, F. et al. Molecular diversity and genome structure in modern sugarcane varieties. Euphytica, v.78, p.217-226, 1994.

MAIER, R.M.; DÖRY, I.; IGLOI, G.L.; KÖSSEL, H. The $n d h H$ genes of gramineam plastomes are linked with the junctions between small single copy and inverted repeat regions. Current Genetics, v.18, n.3, p.245-250, 1990.

MAIER, R.M.; HOCH, B.; ZELTZ, P.; KÖSSEL, H. Internal editing of the maize ndhA transcript restores codons for conserved amino acids. Plant Cell, v.4, n.5, p.609616, 1992.

MAIER, R.M.; NECKERMANN, K.; IGLOI, G.L.; KÖSSEL, H. Complete sequence of the maize chloroplast genome: gene contents, hotspots of divergence and fine tuning of genetic information by transcript editing. Journal of Molecular Biology, v.251, p.614-628, 1995.

MARIAC, C.; TROUSLOT, P.; POTEAUZ, C. et al. Chloroplast DNA extraction from herbaceous and woody plants for direct restriction fragment length polymorphism analysis. Biotecniques, v.28, p.110-113, 2000.

MARTIN, W.; STOEBE, B.; GOREMYKIN, V. et al. Gene transfer to the nucleus and the evolution of chloroplasts. Nature, v.393, p.162-165, 1998.

MARTIN, W.; RUJAN, T.; RICHLY, E.; et al. Evolutionary analysis of Arabidopsis, cyanobacterial and chloroplast genomes reveals plastid phylogeny and thousands of cyanobacterail genes in the nucleus. Proceedings of National Academy of Sciences, v.99, p.12246-12251, 2002.

MASON-GAMER, R.J.; WEIL, C.F.; KELLOG, E.A. Granule-bound starch synthase: structure, function, and phylogenetic utility. Molecular Biology and Evolution, v.15, p.1658-1673, 1998.

MATIOLI, S.R. Biologia molecular e evolução. Ribeirão Preto: Ed. Holos, 2001. 202p. 
MATSUOKA, S.; GARCIA, A.A.F.; CALHEIROS, G.G. Hibridação em cana-deaçúcar. In: BOREM, A. (Ed.). Hibridação artificial de plantas. Viçosa: UFV, 1999. p.221-254.

MATSUOKA, Y.; YAMAZAKI, Y.; OGIHARA, Y.; TSUNEWAKI, K. Whole chloroplast genome comparison of rice, maize, and wheat: implications for chloroplast gene diversification and phylogeny of cereals. Molecular Biology and Evolution, v.12, p.2084-2091, 2002.

McCAULEY, D. E. The use of chloroplast DNA polymorphism in studies of gene flow in plants. Trends of Ecology and Evolution, v.10, p.190-202, 1995.

McFADDEN, G. I. Primary and secondary endosymbiosis and the origin of plastids. Journal of Phycology, v.37, p.951-959, 2001a.

McFADDEN, G. I. Chloroplast origin and integration. Plant Physiology, v.125, p.50$53,2001 b$.

MONDE, R.A.; SCHUSTER, G.; STEM, D.B. Processing and degradation of chloroplast mRNA. Biochimie, v.82, p.573-582, 2000.

MORTON, B.R.; CLEGG, M.T. A chloroplast DNA mutational hotspot and gene conversion in a noncoding region near $r b c L$ in the grass family (Poaceae). Current Genetics, v.4, p.357-365, 1993.

MUASYA, A.M.; SIMPSON, D.A.; CHASE, M.W. Phylogenetic relationships in Cyperus L. s.l. (Cyperaceae) inferred from plastid DNA sequence data. Botanical Journal of the Linnean Society, v.138, p.145-153, 2002.

MUASYA, A.M.; SIMPSON, D.A.; CHASE, M.W.; CULHAM, A. A phylogeny of Isolepis (Cyperaceae) inferred using plastid $r b c L$ and $t r n L-F$ sequence data. Systematics of Botany, v.26, p.342-353, 2001.

MUKHERJEE, S.K. Origin and distribution of Saccharum. Botanical Gazette, v.119, p.55-61, 1957.

MULTIPLE SEQUENCE ALIGNMENT BY FLORENCE CORPET. http://prodes.toulouse.inra.fr/multalin/multalin.html. (15 Apr. 2004).

NADOT, S.; BAJON, R.; LEJEUNE, B. The chloroplast gene rps4 as a tool for the study of Poaceae phylogeny. Plant Systematics and Evolution, v.191, p.27-38, 1994.

NATIONAL CENTER FOR BIOTECHNOLOGY INFORMATION (NCBI). http://www.ncbi.nlm.nih.gov. (15 Apr. 2004). 
NEALE, D.B.; SAGHAI-MAROOF, M.A.; ALLARD, R.W. et al. Chloroplast DNA diversity in populations of wild and cultivated barley. Genetics, v.120, p.1105$1110,1986$.

NEI, M. Molecular Evolutionary Genetics. New York: Columbia Univ. Press, 1987. $512 \mathrm{p}$.

ODINTSOVA, M.S.; YURINA, N.P. RNA editing in chloroplast and plant mitochondria. Genetika, v.37, p.307-320, 2000.

ODINTSOVA, M.S.; YURINA, N.P. Plastid genomes of higher plants and algae: structure and functions. Molecular Biology, v.37, p.649-662, 2003.

OGIHARA, Y.; TERACHI, T., SASAKUMA, T. Intramolecular recombination of chloroplast genome mediated by a short direct-repeat sequence in wheat species. Proceedings of the National Academy of Sciences of the USA, v.85, p.8574-8577, 1988.

OGIHARA, Y., TERACHI, T.; SASAKUMA, T. Molecular analysis of the hot spot region related to length mutations in wheat chloroplast DNAs. I. Nucleotide divergence of genes and intergenic spacer regions located in the hot spot region. Genetics, v.129, p.873-884, 1991.

OGIHARA, Y., TERACHI, T.; SASAKUMA, T. Structural analysis of length mutation in a hot-spot region of wheat chloroplast DNAs. Current Genetics, v.22, p.251$258,1992$.

OGIHARA, Y.; ISONO, K.; KOJIMA, T. et al. Structural features of a wheat plastomes as revealed by complete sequencing of chloroplast DNA. Molecular Genetics and Genomics, v.266, p.740-746, 2002.

OHNISHI, Y.; TAJIRI, H.; MATSUOKA, Y.; TSUNEWAKI, K. Molecular analysis of a $21.1-\mathrm{kbp}$ fragment of wheat chloroplast DNA bearing RNA polymerase subunit (rpo) genes. Genome, v.42, p.1042-1049, 1999.

OLIVEIRA, M.; VASCONCELOS, Y. Soluções para geração de eletricidade. Pesquisa FAPESP, v.65, p.66-69, 2001.

OLMSTEAD, R.G.; PALMER, J.D. Chloroplast DNA systematics: A review of methods and data analysis. American Journal of Botany, v.81, p.1205-1224, 1994.

OLMSTEAD, R.G.; SWEERE, J.A. Combining data in phylogenetic systematics: an empirical approach using three molecular data sets in the Solanaceae. Systematics of Botanic, v.43, p.467-481, 1994. 
OLMSTEAD, R.G.; REEVES, P.A. Evidence for the polyphyly of the Scrophulariaceae based on chloroplast $r b c L$ and $n d h F$ sequences. Annual Missouri Botanical Garden, v.82, p.176-193, 1995.

PAGE, R.D.M. TREEVIEW: An application to display phylogenetic trees on personal computers. Computer Applications in the Biosciences, v.12, p.357-358, 1996.

PALMER, J.D. Plastid chromosomes: structure and evolution. In: VASIL, I.K.; BOGORAD, L., (Ed.). The Molecular Biology of Plastids. Cell culture and somatic cell genetics of plants. San Diego, CA: Academic Press, 1991. v.7, p.5-53.

PALMER, J.D. Cell organelles. In: HERRMANN, R.G. (Ed.). Plant gene research. Vienna: Springer-Verlag, 1992. p.99-122.

PALMER, J.D.; STEIN, D.B. Conservation of chloroplast genome structure among vascular plants. Current Genetics, v.10, p.823-833, 1986.

PALMER, J. D.; DELWICHE, C.F. The origin and evolution of plastids and their genomes. In: SOLTIS, D.E.; SOLTIS, P.S.; DOYLE, J.J. (Ed.). Molecular Systematics of Plants II DNA Sequencing. Boston: Kluwer Academic Publishers, 1998. p. 345-409.

PALMER, J.D.; JANSEN, R.K.; MICAELS, H.J. et al. Chloroplast DNA variation and plant phylogeny. Annual Missouri Botanical Garden, v.75, p.1180-1206, 1988.

PANJE, R.R.; BABU, C.N. Studies in Saccharum spontaneum distribution and geographical association of chromosome numbers. Cytologia, v.25, p.152-172, 1960 .

PHYLOGENETIC ANALYSIS USING PARSIMONY AND OTHER METHODS PAUP*4.0b10. http://paup.csit.fsu.edu/. (15 Apr. 2004).

PERRY, A.S.; BRENNAN, S.; MURPHY, D.J. et al. Evolutionary Re-organization of a Large Operon in Adzuki Bean Chloroplast DNA caused by Inverted Repeat Movement. DNA Research, v.9, p.157-162, 2002.

PIRES, C.E.L.S. Diversidade genética de variedades de cana-de-açúcar (Saccharum spp.) cultivadas no Brasil. Piracicaba, 1993. 120p. Tese (Doutorado) - Escola Superior de Agricultura "Luiz de Queiroz", Universidade de São Paulo.

RENNO, J.F.; MARIAC, C.; POTEAUX, C. et al. Haplotype variation of cpDNA in the agamic grass complex Pennisetum section Brevivalvula (Poaceae). Heredity, v.86, p.537-544, 2001. 
ROACH, B.T.; DANIELS, J. A review of the origin and improvement of sugarcane. In: COPERSUCAR INT SUGARCANE BREED WORKSHOP. Piracicaba: Copersucar, 1987. p.1-32.

ROCHAIX, J.D. Posttranscriptional control of chloroplast gene expression. From RNA to photosynthetic complex. Plant Physiology, v.125, p.142-144, 2001.

ROKAS, A.; HOLLAND, P.W.H. Rare genomic changes as a tool for phylogenetics. Tree, v.15, p.454-459, 2000.

SANKOFF, D.; LEADUC, G.; ANTOINE, N. et al. Gene order comparisons for phylogenetic inference: Evolution of the mitochondrial genome. Proceedings of the National Academy of Sciences of the USA, v.89, p.6575-6579, 1992.

SATO, S.; NAKAMURA, Y.; KANEKO, T. et al. Complete structure of the chloroplast genome of Arabidopsis thaliana. DNA Research, v.6, n.5, p.283-290, 1999.

SCHMITZ-LINNEWEBER, C.; MAIER, R.M.; ALCARAZ, J.P. et al. The plastid chromosome of spinach (Spinacia oleracea): complete nucleotide sequence and gene organization. Plant Molecular Biology, v.45, p.307-315, 2001.

SCHNEIDER, H. Métodos de análise filogenética: um guia prático. Ribeirão Preto: Holos, Editora e Sociedade Brasileira de Genética, 2003. 114p.

SCOTT, S.E.; WILKINSON, M.J. Low probability of chloroplast movement from oilseed rape (Brassica napus) into wild Brassica rapa. Nature Biotechnology, v.17, n.4, p.390-392, 1999.

SETOGUCHI, H.; ONO, M.; DOI, Y.; KOYAMA, H.; TSUDA, M. Molecular phylogeny of Nothofagus (Nothofagaceae) based on the atpB-rbcL intergenic spacer of the chloroplast DNA. Journal of Plant Research, v.110, p.469-484, 1997.

SHIMADA, H.; FUKUTA, M.; ISHIKAWA, M.; SUGIURA, M. Rice chloroplast RNA polymerase genes: the absence of an intron in $\mathrm{rpoCl}$ and the presence of an extra sequence in rpoC2. Molecular and General Genetics, v.221, p.395-402, 1990.

SHINOZAKI, K.; OHME, M.; TANAKA, M.; et. al. The complete nucleotide sequence of the tobacco chloroplast genome: its gene organization and expression. The EMBO Journal, v.5, n.9, p.2043-2049, 1986.

SOBRAL, B.W.S.; BRAGA, D.P.V.; LAHOOD, E.S.; KEIM, P. Phylogenetic analysis of chloroplast restriction enzyme site mutations in the Saccharinae Griseb. subtribe of the Andropogoneae Dumort. tribe. Theoretical and Applied Genetics, v.87, p.843-853, 1994. 
SOLTIS, E.D.; SOLTIS, P.M. Contributions of plant molecular systematics to studies of molecular evolution. Plant Molecular Biology, v.4, p. 45-75, 2000.

SOLTIS, P.S.; SOLTIS, D.E.; CHASE, M.K. Angiosperm phylogeny inferred from multiple genes as a tool for comparative biology. Nature, v.402, p.402-404, 1999.

SPANGLER, R.E.; ZAITCHIK, B.; RUSSO, E.; KELLOGG, E. Andropogoneae evolution and genetic limits in Sorghum (Poaceae) using $n d h F$ sequences. Sistematics of Botanies, v.24, p.267-281, 1999.

STAEHELIN, L.A.; NEWCOMB, E.H. Membrane structure and membranous organelles. In: BUCHANAN, B.; GRUISSEM, W.; JONES, R. (Ed.). Biochemistry and molecular biology of plants. Rockville: Society of Plant Physiologists, 2000. p.358-410.

STEBBINS, G.L. Coevolution of grasses and herbivores. Annual Missouri Botanical Garden, v.68, p.75-86, 1981.

STEELE, K.P.; VILGALYS, R. Phylogenetic analyses of Polemoniaceae using nucleotide sequences of the plastid gene matK. Systematics of Botanic, v.19, p.126-142, 1994.

SUGAR CANE CHLOROPLAST GENOME PROJECT. http://sucest.lad.dcc.unicamp.br/sc-chloroplast. (15 Apr. 2004).

SVENSSON, P.; BLASING, O.E.; WESTHOFF, P. Evolution of $\mathrm{C}_{4}$ phosphoenolpytyvate carboxylase. Archives of Biochemistry and Biophysics, v.2, p.180-188, 2003.

SWOFFORD, D.L. PAUP*: Phylogenetic Analysis Using Parsimony (*and Other Methods). Version 4. Sunderland, Massachusetts: Sinauer Associates, 2003. 1v.

TABERLET, P.; GIELLY, L.; PAUTOU, G.; BOUVET, J. Universal primers for amplification of three non-coding regions of chloroplast DNA. Plant Molecular Biology, v.17, p.1105-1109, 1991.

TAIZ, L.; ZEIGER, E. Plant Physiology. 2.ed. Sunderland: Sinauer Associates, 1998. $315 p$.

TAKAHATA, N. Allelic genealogy and human evolution. Molecular Biology and Evolution, v.10, p.2-22, 1993.

TAXONOMY AND SYSTEMATICS AT GLASGOW - TREEVIEW. http://taxonomy.zoology.gla.ac.uk/rod/treeview.html. (15 Apr. 2004). 
TEKAIA, F.; LAZCANO, A.; DUJON, B. The genomic tree as revealed from whole proteome comparisons. Genome Research, v.9, p.550-557, 1999.

THOMPSON, J.D.; HIGGINS, D.G.; GIBSON, T.J. CLUSTAL W: improving the sensitivity of progressive multiple sequence alignment through sequence weighting, positions-specific gap penalties and weight matrix choice. Nucleic Acids Research, v.33, p.4673-4680, 1994.

TONÉIS \& CIA. http://www.toneis.com.br/modules.php?name=News\&file=article\&sid=55. (15 abr. 2004).

TURMEL, M.; OTIS, C.; LEMIEUX, C. The complete chloroplast DNA sequence of the green alga Nephroselmis olivacea: Insights into the architecture of ancestral chloroplast genomes. Proceedings of the National Academy of Sciences of the USA, v.96, p.10248-10253, 1999.

TURMEL, M.; OTIS, C.; LEMIEUX, C. The chloroplast and mitochondrial genome sequences of the charophyte Chaetosphaeridium globosum: Insights into the timing of the events that restructured organelle DNAs within the green algal lineage that led to land plants. Proceedings of the National Academy of Sciences of the USA, v.99, p.11275-11280, 2002.

UNIÃO DA AGRICULTURA CANAVIEIRA DE SÃO PAULO (ÚNICA). http://www.portalunica.com.br/referencia/estatisticas.jsp. (15 abr. 2004).

WAKASUGI, T.; TSUDZUKI, T.; SUGIURA, M. The genomics of land plant chloroplasts: gene content and alteration of genomic information by RNA editing. Photosynthesis Research, v.70, p.107-118, 2001.

WAKASUGI, T.; SUGITA, M.; TSUDZUKI, T.; SUGIURA, M. Updated gene map of tobacco chloroplast DNA. Plant Molecular Biology Report, v.16, p.231-241, 1998.

WHITCHER, I.N.; WEN, J. Phylogeny and biogeography of Corylus (Betulaceae): inference from ITS sequences. Systematics of Botanic, v.26, p.283-298, 2001.

WILSON, C.A. Phylogenetic relationships in Iris series Californicae based on ITS sequences of nuclear ribosomal DNA. Systematics of Botany, v.28, p.39-46, 2003.

WILSON, A.C.; CARLSON, S.S.; WHITE, T.J. Biochemical evolution. Annual Review of Biochemistry, v.46, p.573-639, 1977.

WOLFE, K.H.; LI, W.H.; SHARP, P.M. Rates of nucleotide substitution vary greatly among plant mitochondrial, chloroplast, and nuclear DNAs. Proceedings of the National Academy of Sciences of the USA, v.84, p.9054-9058, 1987. 
WOLFE, K.H.; ELISENS, W.L.; WATSON, L.E.; DEPAMPHILIS, C.W. Using restriction-site variation of PCR-amplified cpDNA genes for phylogenetic analysis of tribe Cheloneae (Scrophulariaceae). American Journal of Botany, v.84, p.555$564,1997$.

WOLFE, K.H.; GOUY, M.; YANG, Y.W.; SHARP, P.M.; LI, W.J. Date of the monocot-dicot divergence estimated from chloroplast DNA sequence data. Proceedings of the National Academy of Sciences of the USA, v.86, p.6201-6205, 1989.

ZHANG, W. Phylogeny of the grass family (Poaceae) from rpll6 intron sequence data. Molecular Phylogenetics and Evolution, v.15, p.135-146, 2000.

ZURAWSKI, G.; CLEGG, M.T.; BROWN, A.D.H. The nature of nucleotide sequence divergence between barley and maize choloplast DNA. Genetics, v.106, p.735-749, 1984. 